PNL-6862

UC-11, 41

\title{
40 CFR 265 Interim Status Indicator-Evaluation Ground- Water Monitoring Plan for the 216-B-63 Trench
}

B. N. Bjornstad

S. Dudziak

March 1989

Prepared for the U.S. Department of Energy under Contract DE-AC06-76RLO 1830

Pacific Northwest Laboratory Operated for the U.S. Department of Energy by Battelle Memorial Institute 


\title{
DISCLAIMER
}

This report was prepared as an account of work sponsored by an agency of the United States Government. Neither the United States Government nor any agency thereof, nor Battelle Memorial Institute, nor any or their employees, makes any warranty, expressed or implied, or assumes any legal liability or responsibility for the accuracy, completeness, or usefulness of any information, apparatus, product, or process disclosed, or represents that its use would not infringe privately owned rights. Reference herein to any specific commercial product, process, or service by trade name, trademark, manufacturer, or otherwise does not necessarily constitute or imply its endorsement, recommendation, or favoring by the United States Government or any agency thereof, or Battelle Memorial Institute. The views and opinions of authors expressed herein do not necessarily state or reflect those of the United States Government or any agency thereot.

\author{
PACIFIC NORTHWEST LABORATORY \\ operated by \\ BATTELLE MEMORIAL INSTITUTTE \\ for the \\ UNITED STATES DEPARTMENT OF ENERGY \\ under Contract DE-AC06-76RLO 1830
}

\begin{tabular}{|c|c|}
\hline \multicolumn{2}{|c|}{ Printed in the United States of Americz } \\
\hline \multicolumn{2}{|c|}{ Available from } \\
\hline \multicolumn{2}{|c|}{ National Technical Information Service. } \\
\hline \multicolumn{2}{|c|}{ United States Department of Commerc } \\
\hline \multicolumn{2}{|c|}{5285 Port Royal Road } \\
\hline \multicolumn{2}{|c|}{ Springfield, Virginia 22161} \\
\hline \multicolumn{2}{|c|}{ NTIS Price Codes } \\
\hline \multicolumn{2}{|c|}{ Microfiche A01 } \\
\hline \multicolumn{2}{|c|}{ Printed Copy } \\
\hline & Price \\
\hline Pages & Codes \\
\hline $001-025$ & A02 \\
\hline $026-050$ & A03 \\
\hline $051-075$ & A04 \\
\hline $076-100$ & A05 \\
\hline $101-125$ & A06 \\
\hline $126 \cdot 150$ & $\mathrm{~A} 07$ \\
\hline $151-175$ & $\mathrm{~A} 0 \mathrm{~B}$ \\
\hline $176-200$ & $A 09$ \\
\hline 201.225 & A10 \\
\hline $226-250$ & A11 \\
\hline $251-275$ & A.12 \\
\hline $276-300$ & A13 \\
\hline
\end{tabular}


40 CFR 265 INTERIM STATUS INDICATOR-EVALUATION GROUND-WATER MONITORING PLAN FOR THE 216-B-63 TRENCH

B. N. Bjornstad

S. Dudziak

March 1989

Prepared for the U.S. Department of Energy under Contract DE-ACO6-76RL0 1830

Pacific Northwest Laboratory Richland, Washington 99352 


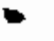

,

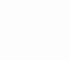




\section{$\underline{\text { SUMMARY }}$}

This document outlines a ground-water monitoring plan for the 216-B-63 trench located in the northeast corner of the 200-East Area on the Hanford Site in southeastern Washington State. It has been determined that hazardous materials (corrosives) were disposed of to the trench during past operations. Installation of an interim-status ground-water monitoring system is required to determine whether hazardous chemicals are leaching to the ground water from beneath the trench.

This document summarizes the existing data that are available from near the 216-B-63 trench and presents a plan to determine the extent of groundwater contamination, if any, derived from the trench. The plan calls for the installation of four new monitoring wells located near the west end of the trench. These wells will be used to monitor ground-water levels and water quality immediately adjacent to the trench. Two existing RCRA monitoring wells, which are located near the trench and hydraulically upgradient of it, will be used as background wells. 


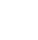




\section{CONTENTS}

SUMMARY ............................

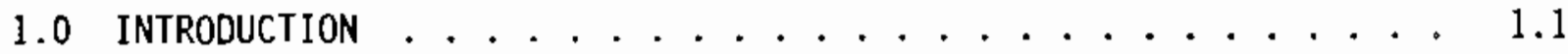

1.1 PURPOSE AND OBJECTIVES . . . . . . . . . . . . 1.1

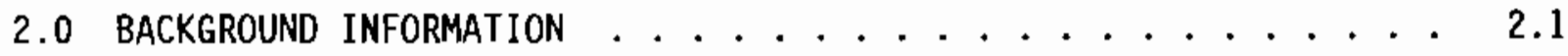

2.1 FACILITY DESCRIPTION . . . . . . . . . . . . 2.1

2.1.1 Location and Physical Description......... 2.1

2.1.2 History of Operation ............... 2.1

2.1.3 Waste Characteristics........... 2.5

2.2 GEOLOGY . . . . . . . . . . . . . . . . . . . . 2.6

2.2.1 Regional Geologic Setting . . . . . . . . 2.8

2.2.2 Geology of the Separations Areas . . . . . . 2.8

2.2 .3 Site Geology ............... 2.14

2.3 HYDROGEOLOGY . . . . . . . . . . . . 2.20

2.3.1 Regional Setting ............ 2.20

2.3.2 Ground-Water Hydrology of the Separations Areas . . 2.22

2.3.3 Hydrogeology Beneath the Site......... 2.28

3.0 PHASE I. GROUND-WATER MONITORING PROGRAM . . . . . . . 3.1

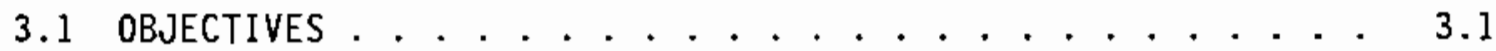

$3.2 \mathrm{APPROACH} \ldots \ldots \ldots \ldots . \ldots . \ldots . \ldots . \ldots$

3.3 GROUNO-WATER MONITORING SYSTEM . . . . . . . . . 3.3

3.3.1 Uppermost Aquifer . . . . . . . . . . 3.3

3.3.2 Background Wells . . . . . . . . . . . 3.4

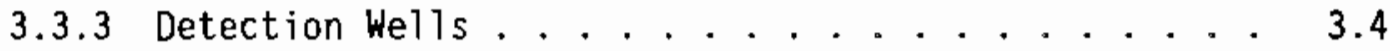

3.3.4 Use of Existing Wells ........... 3.5 
3.3.5 Installation of New Characterization/Monitoring Wells 3.5

3.3.6 Monitoring Parameters . . . . . . . . . . 3.12

3.4 HYDROGEOLOGIC CHARACTERIZATION . . . . . . . . . . 3.12

3.4.1 Geologic Characterization .......... 3.14

3.4.2 Hydrogeologic Characterization . . . . . . . . 3.17

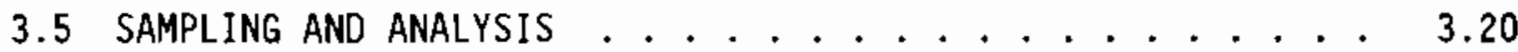

3.6 STATISTICAL ANALYSIS OF GROUND-WATER MONITORING DATA . . . 3.21

3.6.1 Methods..................... 3.21

3.6.2 Establishing Background ............. 3.21

3.6.3 Evaluation of Data .............. . . 3.22

3.6.4 Notification and Reports ........... 3.23

4.0 PHASE II. INITIATION OF GROUND-WATER QUALITY ASSESSMENT

PROGRAM ................................ 4

4.1 INITIATION CRITERIA . . . . . . . . . . . . . . . . 4.1

4.2 GROUND-WATER QUALITY ASSESSMENT PROGRAM . . . . . . . . . . 4.1

4.2.1 Nature and Extent of Contamination . . . . . . 4.2

4.2.2 Rate of Movement . . . . . . . . . . . . . . 4.4

4.2.3 Additional Well Installations........... 4.4

4.2.4 Additional Field and Laboratory Testing . . . . . . . 4.4

4.2.5 Modeling . . . . . . . . . . . . . . . . . 4.5

4.3 CONTINUED ANALYSIS AND EVALUATION . . . . . . . . . . 4.5

4.3.1 Review of Methods and Procedures . . . . . . . . 4.5

4.3.2 Review of Sampling Parameters and Frequency . . . . . 4.6

4.3.3 Notification and Reports . . . . . . . . . . . 4.6

5.0 REFERENCES . . . . . . . . . . . . . . . . . . . . 5.1 
APPENDIX A - GEOLOGIC AND WELL CONSTRUCTION DIAGRAMS

FOR EXISTING WELLS . . . . . . . . . . . . . A.1

APPENDIX B - WATER-CHEMISTRY DATA LISTINGS AND SUMMARIES . . . . B.1

APPENDIX $C$ - SAMPLING AND ANALYSIS PLAN ........... . . . 
1

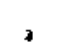

. 


\section{EIGURES}

2.1 Separations Areas Location Map . . . . . . . . . . 2.2

2.2 Location of the 216-B-63 Trench in Relation to the 216-B-2-1,

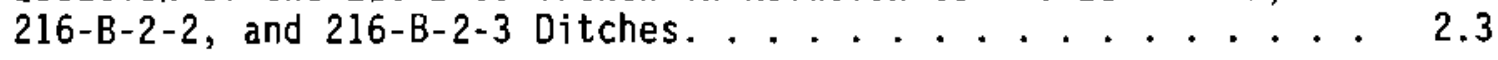

2.3 Location Map of the Hanford Site Within the Pasco Basin Showing Major Structures Within the Basin ......... 2.9

2.4 Geomorphic Features Surrounding the Separations Areas . . . . . 2.10

2.5 Generalized Geologic Columns for the Separations Areas . . . . . 2.12

2.6 Borehole Location Map in the Vicinity of the 216-B-63 Trench . 2.15

2.7 Fence Diagram Around the 216-B-63 Trench . . . . . . . . 2.18

2.8 Isopach Map of the Post-Basalt Sediments . . . . . . . 2.19

2.9 Water-Table Map for the Separations Areas, December 1987. . . . 2.25

2.10 Depth to the Water Table in the Vicinity of the 216-B-63 Trench, March 1988 ........... 2.29

2.11 Base of Unconfined Aquifer in the Vicinity of the 216-B-63 Trench ................ 2.30

2.12 Saturated Thickness of the Unconfined Aquifer in the Vicinity of the 216-B-63 Trench, March 1988....... 2.31

2.13 Water-Table Surface and Directions of Ground-Water Flow in the Vicinity of the 216-B-63 Trench, March 1988. . . . 2.33

3.1 Existing and Planned We1ls Near the 216-B-63 Trench . . . . 3.2

3.2 Schematic Diagram of a Completed Ground-Water Monitoring We11 . 3.9 



\section{$\underline{\text { IABLES }}$}

2.1 B Plant Chemical Sewer Sources . . . . . . . . . 2.4

2.2 Analytical Data from B Plant Laboratory Waste Water . . . . . 2.7

2.3 Borehole Inventory of Wells Near the 216-B-63 Trench. . . . . 2.16

2.4 Bulk Major- and Trace-Element Geochemistry of Sediment

Samples of the Hanford Formation from Well 299-E34-2. . . . 2.21

2.5 Ranges of Hydraulic Properties in the 200-East Area . . . . 2.27

2.6 Hydraulic Properties From Wells Near the

216-B-63 Trench ................ 2.32

3.1 Planned We11 Locations and Depths for the 216-B-63 Trench . . . 3.6

3.2 EPA Interim Primary Drinking Water Standards 40 CFR Part 265, Subpart F . . . . . . . . . . 3.13

3.3 Laboratory Analyses to be Performed as Part of Hydrogeologic Characterization .................. 3.16

3.4 Reports Required by 40 CFR Part 265, Subpart F, for Indicator Evaluation Ground-Water Monitoring . . . . . . . 3.23

4.1 Sample Outline for an Assessment-Leve] Ground-Water Monitoring Plan ............... . . 4.3

4.2 Reports and Notifications to be Submitted During the Assessment-Level Monitoring Program . . . . . . . . . 



\subsection{INTRODUCTION}

This document presents a ground-water monitoring $\mathrm{plan}$ for the 216-B-63 trench Tocated on the Hanford Site in southeastern Washington State. The ground-water monitoring plan, prepared for Westinghouse Hanford Company (Westinghouse Hanford) under subcontract to the U.S. Department of Energy, Richland Operations (DOE-RL), is based on requirements for interim-status facilities, as defined by the Resource Conservation and Recovery Act (RCRA) of 1976 and amended by the Hazardous and Solid Waste Amendments of 1984. These regulations are promulgated by the U.S. Environmental Protection Agency (EPA) in 40 CFR Part 265, Subpart F, and by the Washington State Department of Ecology (hereafter called Ecology) in WAC 173-303-400 (Ecology 1986).

Under RCRA interim status, the 216-B-63 trench requires a ground-water monitoring program. This section presents the purpose, objectives, and scope of the $\mathrm{plan}$ for this program. The 216-B-63 trench receives waste water from the B Plant in the 200-East Area. In the past, this waste water has contained hazardous waste and materials; since 1985, physical controls and operating procedures have been modified to avoid inadvertent discharge of chemicals to the waste-water stream. Because the 216-B-63 trench is not expected to receive additional hazardous substances, DOE-RL has proposed that the trench be closed under RCRA interim status, although it will continue to receive waste water not regulated under RCRA (DOE 1987).

\subsection{PURPOSE AND OBJECTIVES}

The purpose of this plan is to present a program that is capable of determining the impact of the 216-B-63 trench on the quality of the uppermost aquifer underlying the facility to comply with RCRA regulation (40 CFR Part 265, Subpart F). Specific objectives include:

- Presenting an initial ground-water monitoring system that is able to provide a preliminary indication if any hazardous constituents have migrated from the site to ground water

- Presenting an initial hydrogeologic characterization plan. 
This document presents an overview of the 216-B-63 trench, the waste characteristics of the discharges to the trench, the geology and hydrology of the area, the ground-water monitoring indicator evaluation program, and an outline of a ground-water quality assessment program.

The hydrogeologic characterization activities and ground-water monitoring system presented in this plan constitute an initial program. Hydrogeologic data and information and ground-water chemistry data will be interpreted and evaluated before initiating additional hydrogeologic characterization and well-installation activities. 


\subsection{BACKGROUND INFORMATION}

The U.S. Department of Energy's Hanford Site is located in southeastern Washington State (Figure 2.1). The Hanford Site is used for nuclear reactor operations, spent fuel reprocessing, and radioactive waste management. The fuel reprocessing and radioactive waste management facilities in the 200-East and 200-West Areas (the Separations Areas) are operated by Westinghouse Hanford.

\subsection{FACILITY DESCRIPTION}

The following description of the facility includes a discussion of the physical layout of the 216-B-63 trench as well as the documented history of operation within B Plant, the source of effluent discharged to the trench. Most of the following facility description is from DOE (1987). Other sources of information on effluents discharged to the trench are Maxfield (1979), Jungfleisch (1988), and Coony et al. (1988).

\subsubsection{Location and Physical Description}

The 216-B-63 trench is located in the northeast portion of the 200-East Area (Figure 2.1). The 216-B-63 trench parallels the western end of the 216-B-2 ditches (Figure 2.2). It is an open, artificial, earthen trench approximately $4 \mathrm{ft}$ wide at the bottom, $10 \mathrm{ft}$ deep, and $1400 \mathrm{ft} 1 \mathrm{ong}$. The trench is unlined and has been used to dispose of radioactive (low-level) waste water, which is allowed to evaporate and percolate into the underlying soils. The B Plant chemical sewer discharges into the west end of the trench through a 15-in.-diameter vitrified clay pipe. The first $10 \mathrm{ft}$ of the trench is lined with gravel for erosion control. Only the first $860 \mathrm{ft}$ of the trench contains water, as a result of the placement of a small earthen dam at this point. The depth of water varies from approximately $1.5 \mathrm{ft}$ at the head end to $\mathrm{l} \mathrm{ft}$ at the lower end. The trench is closed at the east end and does not convey effluent to any other facilities.

\subsubsection{History of Operation}

The 216-B-63 trench receives liquid waste from a B Plant waste stream commonly known as the B Plant chemical sewer. Sources of waste water 


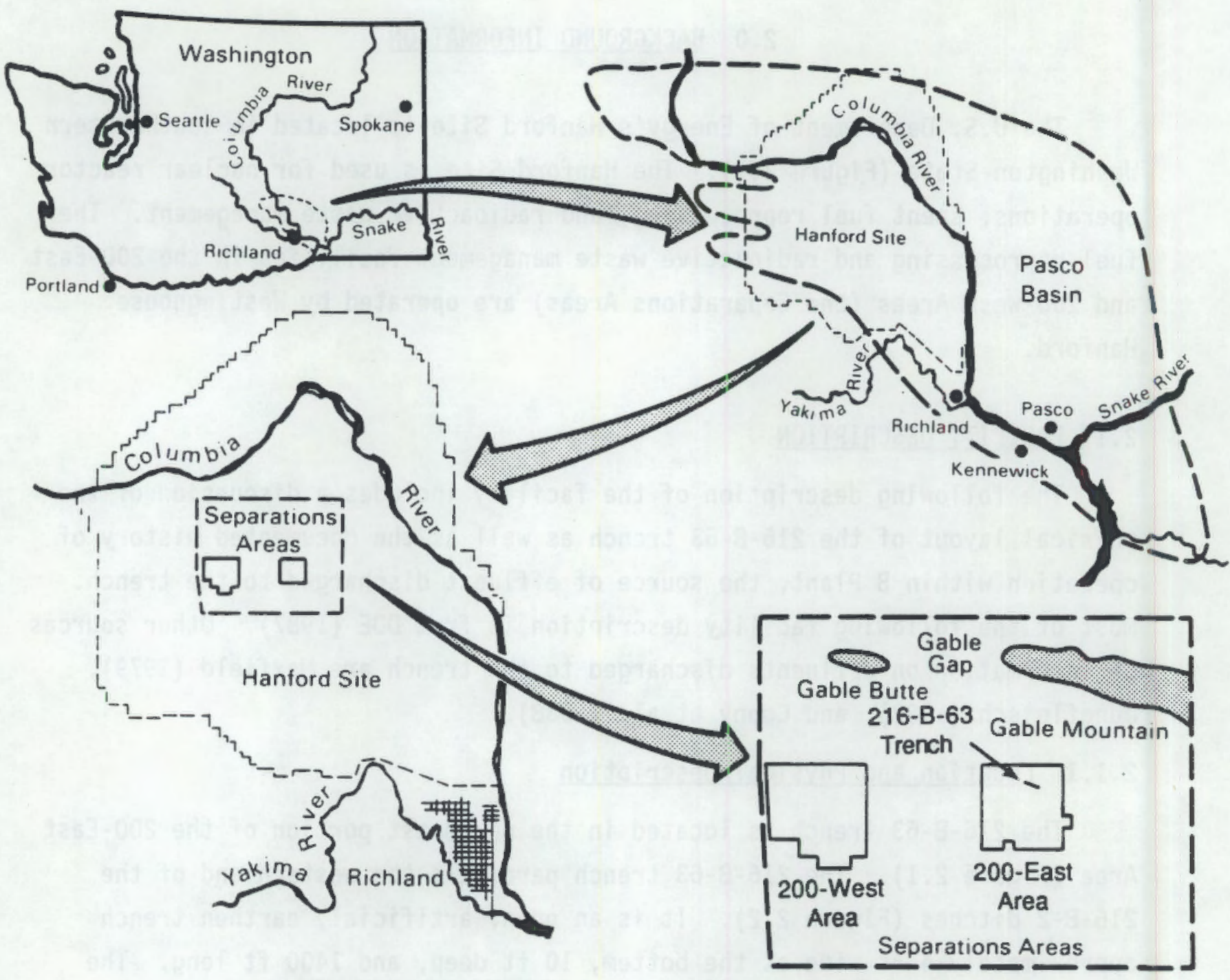

FIGURE 2.1. Separations Areas Location Map

discharged to the chemical sewer at B Plant include drains from chemical storage and chemical makeup areas, effluents from the plant water demineralizers, steam condensate from tank heating coils, cooling water from air compressors, rain water, office floor drains, and overflow from the B Plant water tower (Table 2.1). The approximate average flow rate of waste water discharged to the 216-B-63 trench varies from 100,000 to 400,000 gallons per day (gpd). As a result, some water is present in the trench most of the time. Flow rates are monitored by a 1.5-in. flowmeter installed near the point where the effluent enters the trench. 


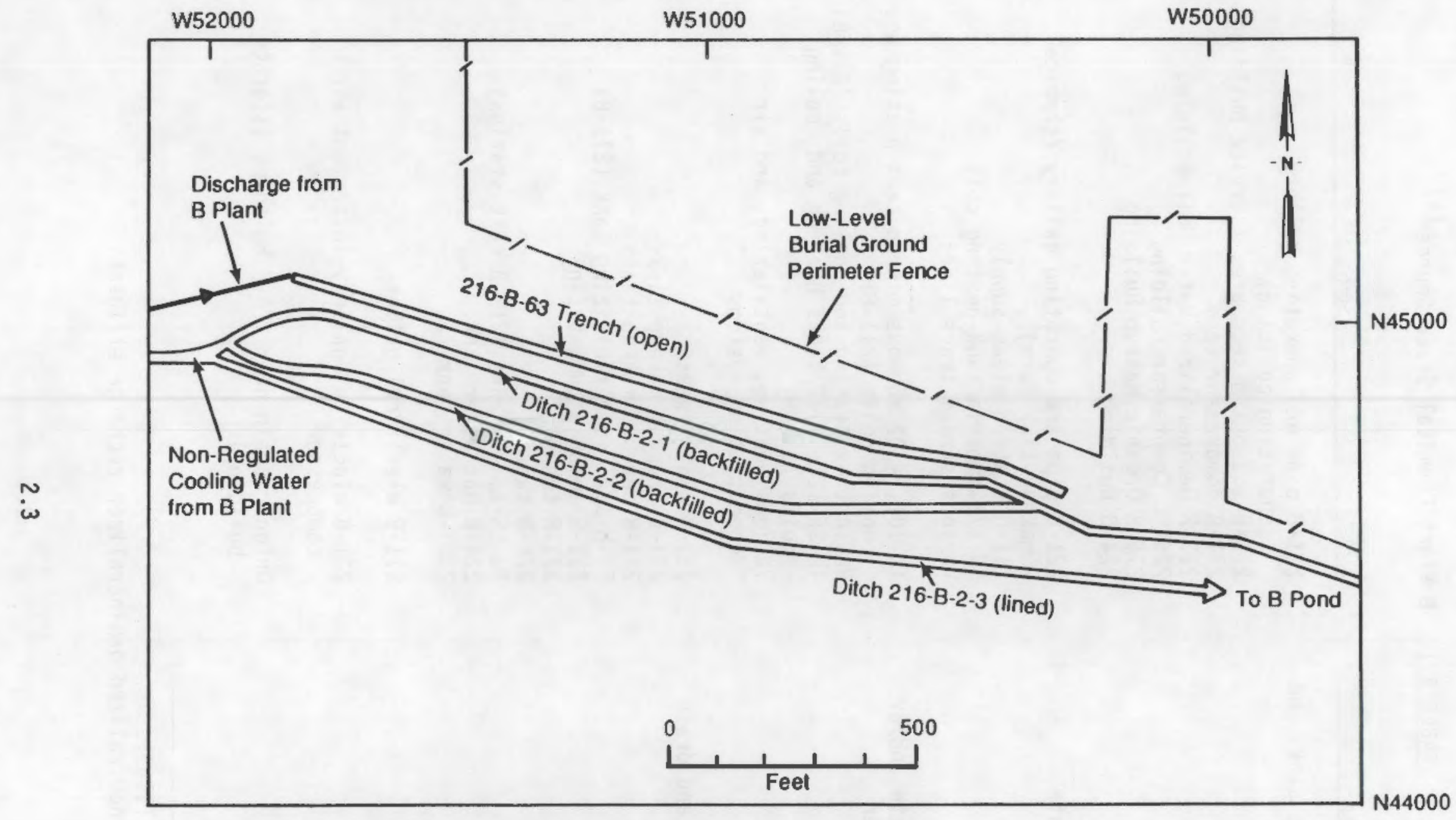

FIGURE 2.2. Location of the 216-B-63 Trench in Relation to the 216-B-2-1, 216-B-2-2, and 216-B-2-3 Ditches 
TABLE 2.1. B Plant Chemical Sewer Sources(a)

\section{Stream}

Floor, funnel, sink, and drains

Steam condensate

Steam condensate and/or cooling water

Tank overflow and drain effluent

Sump effluent

cooling water

Rainwater
Source

221-B pipe and operating gallery (separation building)

271-B aqueous makeup area (service building) 271-B compressor room

217-B Demineralized Water Unit Building

225-BC Compressor Building

276-B Organic Makeup Building

224-B Building

221-B pipe and operating gallery (chemical makeup tank farm)

211-B station steam supply

SN-172 ammonia tank heating coil

Various stream trace lines

TK-101, -102 aqueous makeup tank heating and cooling coils (211-B)

HEDTA tank heating and cooling coils (211-B)

TK-SF-121, -122 tanks heating and cooling coils (211-B)

Various heating, ventilating, and air conditioning systems

221-B scale tanks

221-B aqueous makeup tanks

271-B aqueous makeup tanks

TK-H-317 resin fluidizing tank (271-B)

211-B ammonja pump basin

$271-B$ tanks $(b)$

276-B tanks

TJ-CS-1, -2 tanks (212-B cask station)

224-B hot water tank

2901-B water tank

211-B electrical gallery

211-B electrical gallery instrument air compressor

Outdoor drain near 224-B Building (storage building)

(a) From DOE (1987).

(b) Includes neutralized demineralizer recharge effluent. 
The 216-B-63 trench has been in operation since March 1970. Since that time, the only documented hazardous effluent discharged consisted of regeneration solutions from the $\mathrm{B} P \mathrm{Pl}$ ant demineralizers. These effluents were routine corrosive discharges of aqueous sulfuric acid and sodium hydroxide solutions. Demineralizer effluents were released sequentially from anion and cation columns, a procedure that produced effluent beyond the $\mathrm{pH}$ limits of 2.0 and 12.5. These corrosive discharges occurred from 1970 until October 1985 .

The current practice is to divert each effluent to a holding tank where the cation column effluent is neutralized with sodium carbonate and the anion column effluent is neutralized with monosodium phosphate. Once neutralized to a pH between 4 and 10 , the effluents are released to the chemical sewer. Procedural controls instituted since 1984 also require neutralization of corrosive chemicals before they are released from storage or makeup tanks, and they forbid the intentional release of hazardous materials to the chemical sewer. The waste stream currently has inline monitors, for beta and gamma radiation and for $\mathrm{pH}$ (Coony et al. 1988).

In the past, floor drains, funnel drains, and tank overflow/drain and heating and cooling coils in 225-B (encapsulation facility portion of $B$ Plant) were discharged into the chemical sewer. This facility has been shut down and no longer produces waste. All its drains and discharges have been covered or plugged.

Although the 216-B-63 trench was placed in service in March 1970, the bottom and sides of the 216-B-63 trench were dredged out in August 1970 and the dredgings buried in the Low-Level Burial Grounds in the 200-East Area. The dredgings were found to be contaminated with approximately 3000 counts per minute of beta-gamma activity at that time (PNL 1987).

\subsubsection{Waste Characteristics}

Water, the principal substance making up discharge to the 216-B-63 trench, consists of $70 \%$ steam condensate from tank heating coils and air compressors, and 30\% raw water from such sources as rainwater and overflow from the $B P 1$ ant water tower. Contaminants mixed with this waste water may be derived from chemical storage and chemical makeup areas, effluent from 
plant water demineralizers, and/or floor, funnel, and sink drains connected to B Plant facilities (Table 2.1). It is estimated that the B Plant chemical sewer transported nearly $4700 \mathrm{~kg}$ of nitrate and $715 \mathrm{~kg}$ of total organic carbon in 1987 (Coony et a1. 1988). Maximum discharge temperatures for all individual sources are less than $100^{\circ} \mathrm{F}$, except for the 221-B Pipe and Operating ( $P \& 0)$ Gallery steam condensate, which is $212^{\circ} \mathrm{F}$. This condensate contributes 1,000 to 2,000 gpd under normal operating conditions.

The effluent stream is monitored continuously at two locations for radiation and sampled weekly for chemical analysis. Concentrations of chemical constituents, as well as other water quality parameters, are 1isted for a period from 1985 to 1986 in Table 2.2. As demonstrated in Table 2.2, concentrations of most constituents, as well as pH, showed considerable variation over a relatively short sampling period (less than 1 year). According to Jungfleisch (1988), none of the sampled discharges into the 216-B-63 trench are classified as dangerous waste or extremely hazardous waste as specified by the Dangerous Waste Regulations of the State of Washington (Ecology 1986).

\subsection{GEOLOGY}

This section provides background information on the geology of the Hanford Site, the Separations Areas, and the 216-B-63 trench to support the preparation of the indicator-evaluation ground-water monitoring program presented in Chapter 3.0. The geology of the Columbia Plateau and particularly the Pasco Basin has been studied in detail for DOE as a part of the siting studies for a deep geologic repository for nuclear waste. The Consultation Draft, Site Characterization Plan (DOE 1988) summarizes much of the information known about the Hanford Site, especially near the 200-West Area, where the candidate repository site was located. Studies have also been done in support of nuclear power plant licensing efforts, including those for the Washington Public Power Supply System (Supply System 1981) and the Skagit/Hanford Project (PSPL 1982). More detailed information is available in the following reports:

- on the structural geology and tectonics - Caggiano and Duncan (1983); Reidel et al. (1982); and Tolan (1986) 


\section{TABLE 2.2. Analytical Data from B Plant Laboratory Waste Water}

\begin{tabular}{|c|c|c|c|c|}
\hline Paremeter & Sept. 12, 1985 & April 9, 1986 & April 15. 1986 & June 30,1986 \\
\hline Aluminum & $<150$ & 500 & 160 & $<150$ \\
\hline Anmonium & $<20$ & $<50$ & $<50$ & $<50$ \\
\hline Antimory & $<100$ & $<100$ & $<100$ & $<100$ \\
\hline Barium & 28 & 120 & 23 & 28 \\
\hline Beryllium & $<5.0$ & $<5.0$ & $<5.0$ & $<5.0$ \\
\hline Cadnium & 2.0 & $<2.0$ & 2.0 & $<2.0$ \\
\hline Calcium & 17,000 & 170,000 & 18,000 & 17,000 \\
\hline Chlorine & 1,100 & 1,400 & 14,000 & 960 \\
\hline Chromium & $<10$ & $<10$ & $<10$ & $<10$ \\
\hline Copper & 10 & 89 & 15 & $<10$ \\
\hline Cyanide & 17 & $<10$ & $<10$ & $<10$ \\
\hline Fluorine & 1,500 & 2,800 & 7,500 & $<500$ \\
\hline Iron & 160 & 1,700 & 230 & $\pi$ \\
\hline Lead & $<30$ & .. & . & -- \\
\hline Mercury & $<0.1$ & 0.1 & $<0.1$ & $<0.1$ \\
\hline Magnes ium & 3,600 & 48,000 & 4,200 & 4,000 \\
\hline Manganese & 16 & 44 & 8.0 & 10 \\
\hline Nickel & $<10$ & $<10$ & 11 & $<11$ \\
\hline Nitrate & 530 & $<500$ & 1,900 & 2,600 \\
\hline Phosphate & $<1,000$ & $<1,000$ & $<1,000$ & $<1,000$ \\
\hline Potassium & 1,200 & 6,600 & 960 & 820 \\
\hline Osmium & $<300$ & $<300$ & $<300$ & $<300$ \\
\hline Silver & $<10$ & $<10$ & $<10$ & $<10$ \\
\hline Sulfate & 10,000 & $2,900,000$ & 130,000 & 11,000 \\
\hline Sulfur & $<1,000$ & $<1,000$ & 500 & $<1,000$ \\
\hline Sodium & 150,000 & 410,000 & 650,000 & 2,900 \\
\hline Stront ium & $<300$ & 670 & $<300$ & $<300$ \\
\hline Tin & $<300$ & $\ldots$ & -. & $\cdots$ \\
\hline Uranium & 0.51 & 4.6 & 3.5 & 0.47 \\
\hline Vanadium & $<5.0$ & $<5.0$ & $<5.0$ & $<5.0$ \\
\hline Zinc & 12 & 420 & 67 & 9.0 \\
\hline Acetone & $<10$ & $<10$ & 29 & $<10$ \\
\hline Alkanes & $<10$ & 13 & 210 & $<10$ \\
\hline Butyraldehyde & 12 & $<10$ & $<10$ & $<10$ \\
\hline Chtoroform & $<10$ & $<10$ & 10 & $<10$ \\
\hline Phenol & $<10$ & $<10$ & 8.4 & $<10$ \\
\hline PH & 11.60 & 2.28 & 12.67 & 6.40 \\
\hline Water volume $(L / m o)$ & $20,000,000$ & $38,000,000$ & $38,000,000$ & $38,000,000$ \\
\hline Temperature ( $\left.{ }^{\circ} \mathrm{F}\right)$ & 75.2 & 59.0 & 59.0 & 78.8 \\
\hline Alpha activity ( $p C i / L)$ & 0.37 & 3.1 & 13 & $<4.0$ \\
\hline Beta activity (pCi/L) & 15 & 51 & 27 & 310 \\
\hline Conductivity $(\mu \mathrm{S} / \mathrm{cm})$ & 1,200 & -- & -- & 130 \\
\hline Total organic carbon & 1,800 & 2,800 & 51,000 & 2,500 \\
\hline
\end{tabular}

(a) All values are reported in units of parts per billion (ppb) unless otherwise indicated, except ph, which is dimensionless.

Source: DCE 1987.

- on the basalt stratigraphy and chemistry - Swanson et al. (1979) and Reidel et al. (1982)

- on the sedimentary units interfingered with and overlying the basalts - Bjornstad (1984, 1985); Fecht et al. (1985); Myers/Price et al. (1979); Myers and Price (1981); and Graham et al. (1984). Tallman et al. (1979) is the only in-depth study of the geology of the Separations Areas. 


\subsubsection{Regional Geologic Setting}

The Hanford Site lies within the Columbia Plateau, which is generally characterized by a thick sequence of tholeiitic basalt flows called the Columbia River Basalt Group (Swanson et al. 1979). These flows have been folded and faulted, creating broad structural and topographic basins separated by asymmetric anticlinal structures (i.e., ridges). The Hanford Site lies within one of these basins, the Pasco Basin (Figure 2.3).

Principal geologic units within the Pasco Basin include, in ascending order, the Columbia River Basalt Group (Miocene), the Ringold Formation (Miocene-P1iocene), and the Hanford formation (Pleistocene). A regionally discontinuous veneer of recent alluvium, colluvium, and/or eolian sediments overlies the principal geologic units.

\subsubsection{Geology of the Separations Areas}

The surface topography of the Separations Areas is primarily the result of two geomorphic processes: 1) Pleistocene cataclysmic flooding, and 2) Holocene eolian activity. Cataclysmic flooding, which ended about 13,000 years ago (Mullineaux et al. 1978), created Cold Creek bar (Bretz et a1. 1956), a prominent flood feature within the Separations Areas (Figure 2.4). The last cataclysimic flood(s) covered the Separations Areas with a blanket of coarse-grained deposits, which become finer-grained to the south. The northern boundary of the cold Creek bar is defined by an erosional channel running east-southeast, which formed during waning stages of flooding as floodwaters drained from the basin (Bjornstad et al. 1987).

Since the end of the Pleistocene, winds have reworked the surface of the glaciofluvial sediments locally, depositing a thin veneer of eolian sand in places. Holocene sand dunes are present along the southern boundary of the 200-East Area (Figure 2.4). Holocene alluvium, associated with the cold Creek-Dry Creek alluvial plain, was deposited less than $1 \mathrm{mi}$ southwest of the 200-West Area (Figure 2.4).

The Separations Areas lie within the Cold Creek syncline, which is bounded on the north by the Umtanum Ridge-Gable Mountain anticlinal structure and on the south by the Yakima Ridge anticlinal structure (Figure 2.3). 


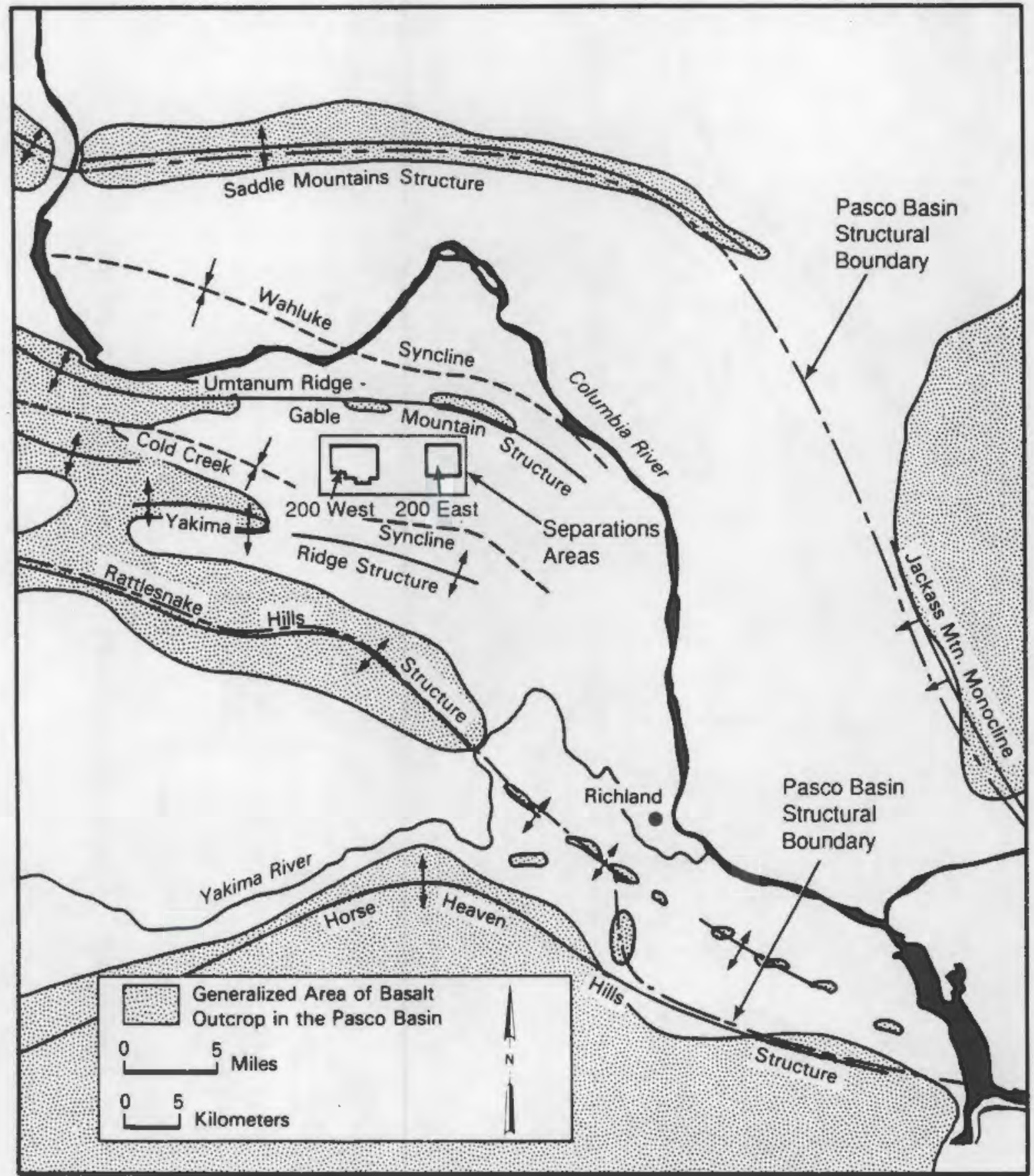

FIGURE 2.3. Location Map of the Hanford Site Within the Pasco Basin Showing Major Structures Within the Basin 


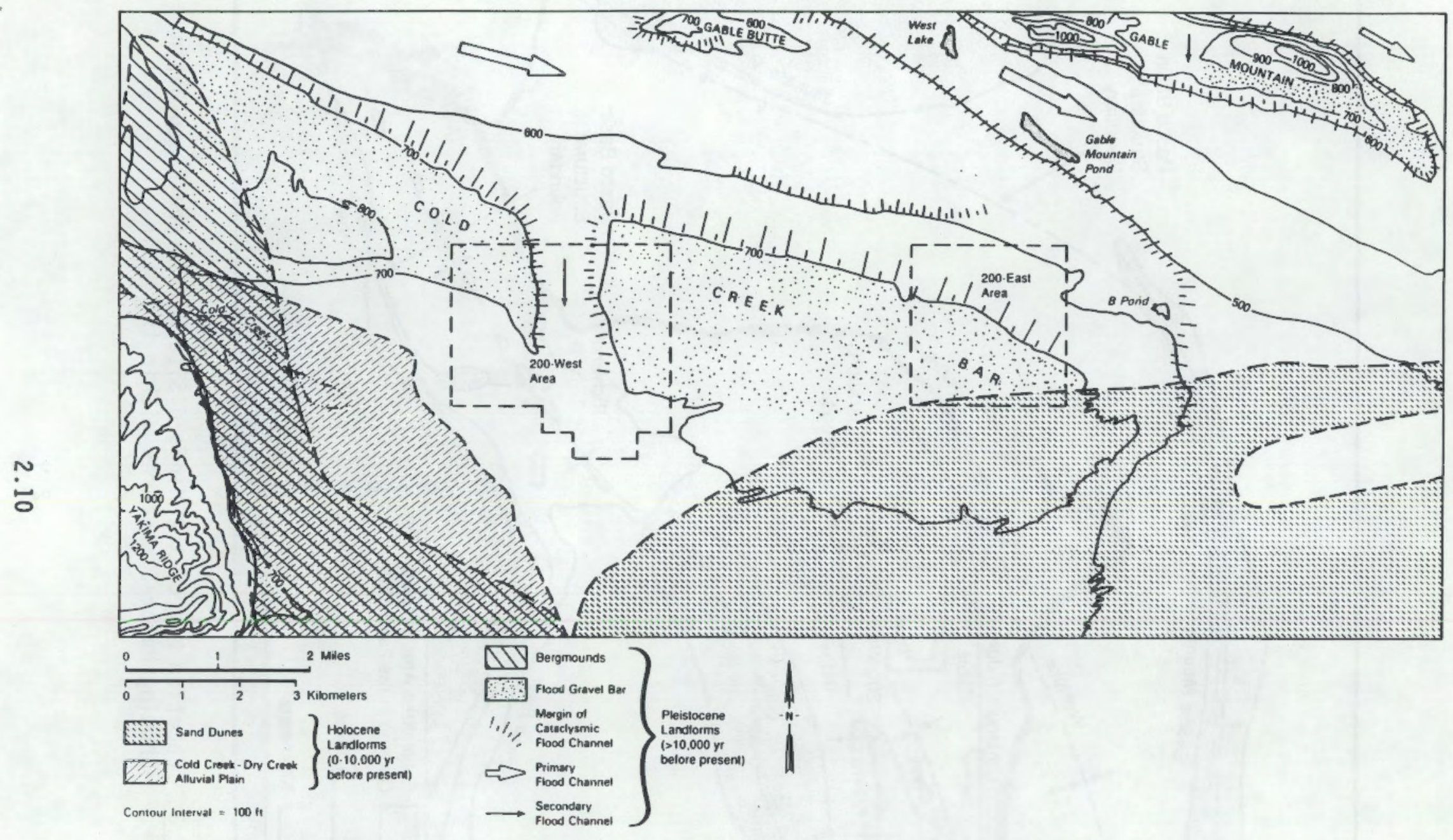

FIGURE 2.4. Geomorphic Features Surrounding the Separations Areas 
In the Separations Areas, the top of basalt generally dips gently (less than $5^{\circ}$ ) to the south-southwest, except in the southwest corner of the 200-West Area, where beds are nearly horizontal along the axis of the Cold Creek syncline.

The generalized stratigraphy of the Separations Areas is shown in Figure 2.5. Bedrock is composed of basalt flows and sedimentary interbeds, which belong to the Columbia River Basalt Group and Ellensburg Formation, respectively. Overlying Columbia River basalt is the fluvial-lacustrine Ringold Formation consisting of variably mixed and interbedded layers of gravel, sand, and mud (i.e., silt and clay). The thickness of the Ringold Formation ranges from $0 \mathrm{ft}$ in the northern part of the 200-East Area to about $500 \mathrm{ft}$ in the southwest portion of the 200-West Area near the axis of the Cold Creek syncline (DOE 1988; Tallman et al. 1979).

The Ringold Formation is divided into four stratigraphic units: basal, lower, middle, and upper. The basal Ringold unit consists of silty sandy gravel overlain by a fining upward sequence of sand and mud. Overlying the basal Ringold is the lower Ringold unit, another fine-grained unit consisting of mostly mud. Sediments of the lower Ringold and upper basal Ringold units have been recognized locally as a potential confining layer.

Where present, the Ringold Formation is dominated by the middle unit in the vicinity of the Separations Areas. The predominant texture consists of we 11-rounded sandy gravel with some sand and silty sand lenses. The gravels typically range from pebble to cobble in size; however, boulders are locally common (Tallman et a1. 1979). Because of their textures and the similarity of their gravel lithologies, the coarse-grained basal and middle Ringold units are difficult to distinguish unless separated by the fine-grained sediments of the upper basal Ringold unit or the lower Ringold unit. The uppermost unit, the upper Ringold, is another sequence of thinly bedded, well-sorted sand and/or mud (DOE 1988; Tallman et al. 1979).

Not all of the units of the Ringold Formation are present throughout the Separations Areas. Erosion by the ancestral Columbia River and later cataclysmic flooding during the Pleistocene Epoch have removed some or all of the Ringold Formation in areas (DOE 1988; Tallman et al. 1979). All four 


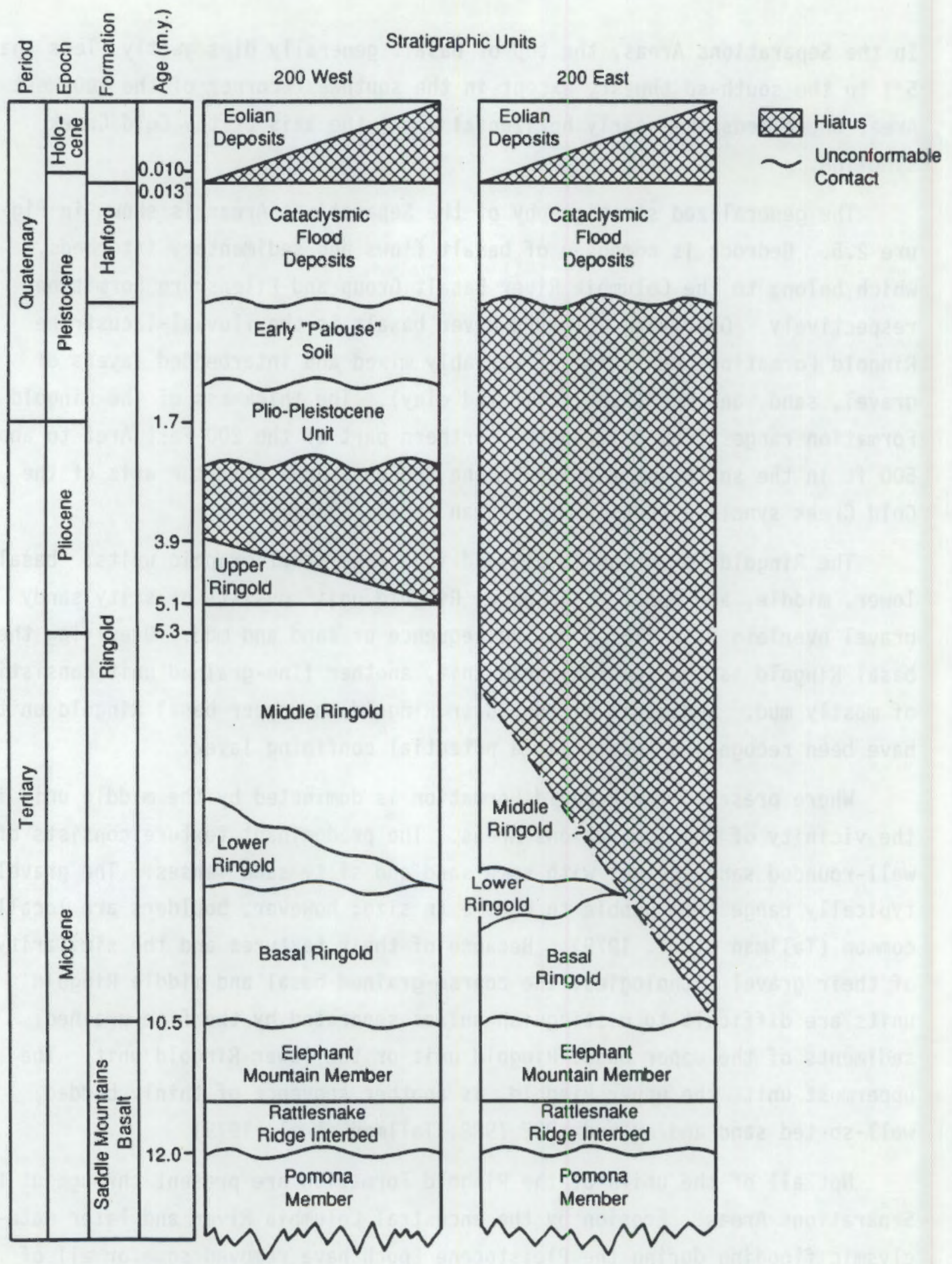

FIGURE 2.5. Generalized Geologic Columns for the Separations Areas 
units are currently identified only in the western and southern portion of the 200-West Area, while little or no Ringold is present in the northeastern part of the 200-East Area (Tallman et al. 1979; Last et al. 1989).

A well-developed calcrete belonging to the Plio-Pleistocene unit is found on the uppermost surface of the eroded Ringold sediments in the 200-West Area (Bjornstad 1984; Last et al. 1989). In places, the PlioPleistocene unit is overlain by as much as $30 \mathrm{ft}$ of early "Palouse" soil, an eolian deposit of fine-grained sand and silt. Both of these units are present over most of the 200-West Area, but they have apparently eroded from the 200-East Area.

The cataclysmic flooding that eroded the Ringold Formation also deposited a sequence of relatively unconsolidated mud, sand, and gravel informally called the Hanford formation. At least four major flood events occurred in the Pasco Basin during the Pleistocene (Fecht et al. 1985). Near flood channels (e.g., in the northern 200-East Area), the Hanford formation consists of dominantly coarse gravel and sand (Pasco Gravels facies), while to the south and west more slack-water type deposits of sand and silt lie between or beneath coarse-grained flood deposits (Last et al. 1989). Within much of the southern portion of the Separations Areas, the Hanford formation consists predominantly of sand. Thickness of the formation ranges from approximately $70 \mathrm{ft}$ in part of the 200 -West Area to a maximum of about $350 \mathrm{ft}$ east of the 200-East Area (Tallman et al. 1979).

The contact between the Hanford and Ringold formations is commonly a transition upward from more indurated deposits containing a variety of 1 ithologies (Ringold Formation) to very weakly cemented or unconsolidated sediments with a higher proportion of basaltic clasts (Hanford formation). The textures of the Pasco Gravels and the middle Ringold are similar, al though the difference in gravel lithologies can sometimes be used to distinguish between the two. However, in some places, basalt-rich gravel layers have been found in the middle Ringold unit, and if the middle Ringold and Pasco Gravels are not separated by the upper Ringold, the PlioPleistocene unit, and/or the early "Palouse" soil, they can be difficult to 
distinguish. This is particularly true where considerable reworking and incorporation of the Ringold sediments into the Hanford formation has occurred.

Graham et al. (1984) indicate the possibility that the Elephant Mountain Member has been completely eroded near the northeast corner of the 200-East Area, with partial erosion over a larger area. This may result in the Hanford formation directly overlying the Rattlesnake Ridge interbed northeast of the 200-East Area.

\subsubsection{Site Geology}

The 216-B-63 trench lies at an elevation of about $640 \mathrm{ft}$ along the northern flank of Cold Creek bar. Cold Creek bar formed along the margin of a Pleistocene-age cataclysmic flood channel, located in the northeastern portion of the 200-East Area (see Figure 2.4). The land surface in the vicinity of the trench dips at $-145 \mathrm{ft} / \mathrm{mi}\left(<2^{\circ}\right)$ to the northeast, toward the axis of the paleochannel.

An interpretation of the subsurface geology near the site is based on an examination of sieve data, drillers' logs, and natural gamma logs from 25 wells nearest the 216-B-63 trench, shown in Figure 2.6. An inventory of the data on these wells, used to generate contour maps in this report, is listed in Table 2.3. We11-construction and geologic logs for three of these wells, located within $1000 \mathrm{ft}$ of the trench, are presented in Appendix A.

A three-dimensional representation of the subsurface geology is presented in Figure 2.7. Essentially, only a single stratigraphic unit, the Hanford formation, overlies basalt beneath the site; according to Last et al. (1989), the Ringold Formation pinches out $2000 \mathrm{ft}$ to the southwest (Figure 2.8). Based on the limited borehole data presented in Figure 2.7, the sediments directly beneath the 216-B-63 trench appear to be mostly mixtures of sand and gravel associated with high-energy deposition by cataclysmic floods. Lateral facies changes occur in the flood deposits to the south and west, however, away from the axis of the main flood channel. Along the southern margin of the flood channel, deposits become finer grained and include layers of fine sand, silt, and occasionally mud, which could act locally as aquitards leading to perched-water conditions. The thickness of 


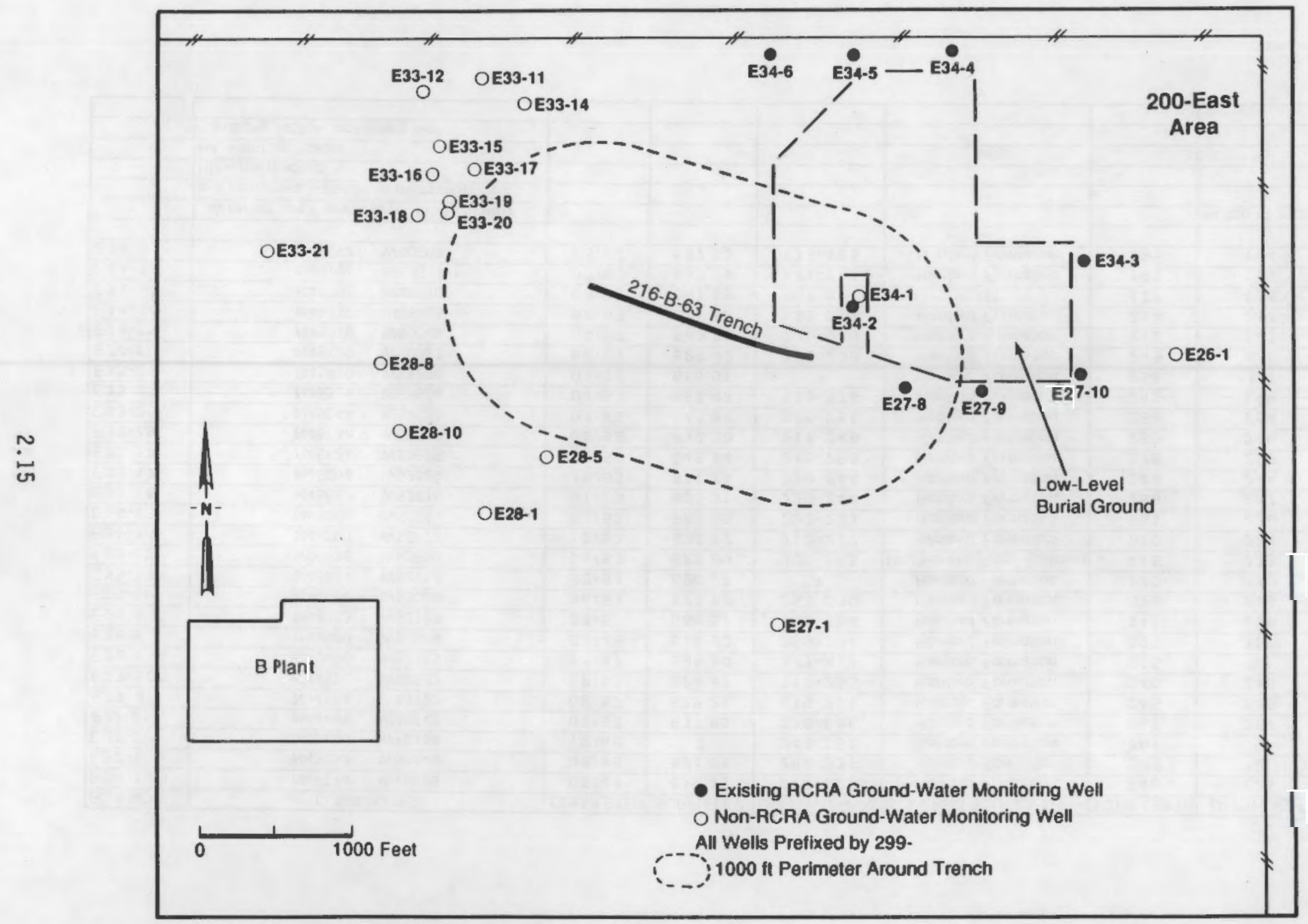

FIGURE 2.6. Borehole Location Map in the Vicinity of the 216-B-63 Trench 
TABLE 2.3. Borehole Inventory of Wells Near the 216-B-63 Trench

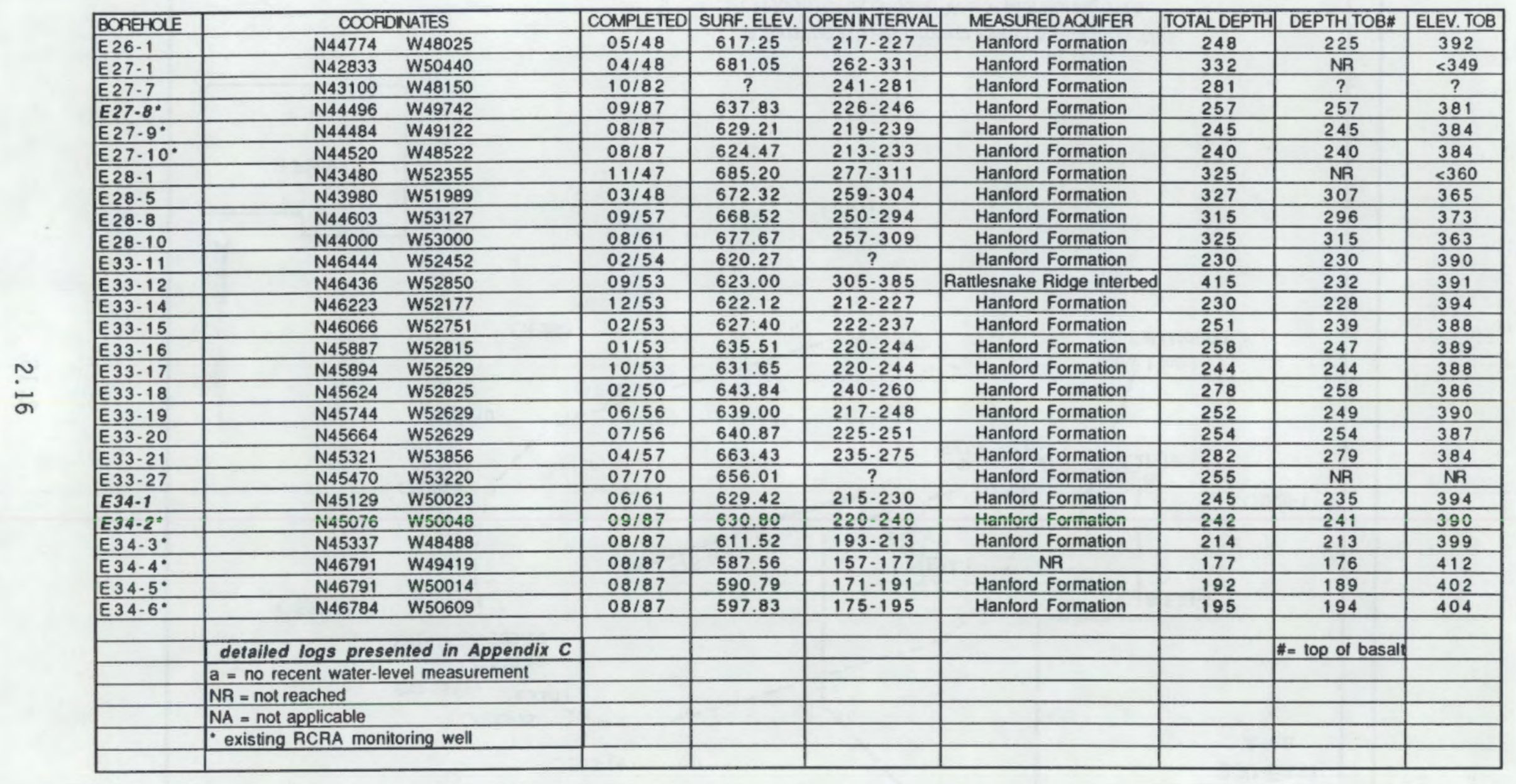


IABLE 2.3. (contd)

\begin{tabular}{|c|c|c|c|c|c|c|c|c|}
\hline BOREHOE & WATERDEPTH & WATER TABLE & MEASURED & SAT. THICK. & SIEVE DATA & NATGAM LOG & DRIUERS LOG & USED \\
\hline E26-1 & 210.92 & 406.33 & $3 / 31 / 88$ & 14.3 & $\mathrm{Y}$ & $Y$ & $Y$ & $Y$ \\
\hline E27-1 & 275.24 & 405.81 & $3 / 31 / 88$ & $>56.8$ & $Y$ & $\mathbf{N}$ & $Y$ & $Y$ \\
\hline E27.7 & $a$ & a & a & $a$ & $\mathbf{N}$ & $\mathbf{N}$ & $Y$ & $\mathbf{N}$ \\
\hline E27. $0^{\circ}$ & 232.46 & 405.37 & $3 / 31 / 88$ & 24.4 & $Y$ & $Y$ & $Y$ & $Y$ \\
\hline E27.9. & 223.68 & 405.53 & $3 / 31 / 88$ & 21.5 & $Y$ & $Y$ & $\bar{Y}$ & $\bar{Y}$ \\
\hline E27.10 & 218.54 & 405.93 & $3 / 31 / 88$ & 21.9 & $Y$ & $Y$ & $Y$ & $Y$ \\
\hline$E 28-1$ & $a$ & $a$ & $a$ & $a$ & $\bar{Y}$ & $Y$ & $Y$ & $Y$ \\
\hline$E 28.5$ & 266.69 & 405.63 & $3 / 31 / 88$ & 40.6 & $Y$ & $Y$ & $Y$ & $Y$ \\
\hline E28-8 & 362.99 & 405.53 & $3 / 31 / 88$ & 32.5 & $Y$ & $Y$ & $Y$ & $Y$ \\
\hline E28-10 & 272.04 & 405.63 & $3 / 31 / 88$ & 42.6 & $\mathbf{N}$ & $Y$ & $Y$ & $Y$ \\
\hline E33-11 & a & a & $a$ & a & $Y$ & $Y$ & $Y$ & $Y$ \\
\hline E33-12 & 217.47 & 405.53 & $3 / 31 / 88$ & 14.5 & $Y$ & $Y$ & $Y$ & $Y$ \\
\hline E33.14 & 216.65 & 405.47 & $3 / 31 / 88$ & 11.5 & $Y$ & $Y$ & $Y$ & $Y$ \\
\hline E33-15 & a & a & a & $a$ & $Y$ & $Y$ & $\bar{Y}$ & $\bar{Y}$ \\
\hline E 33.16 & $a$ & a & a & $a$ & $\bar{Y}$ & $Y$ & $Y$ & $Y$ \\
\hline E33-17 & 226.65 & 405.00 & $12 / 11 / 87$ & 17.4 & $Y$ & $Y$ & $Y$ & $Y$ \\
\hline E33-18 & 239.31 & 404.53 & $11 / 9 / 88$ & 18.5 & $Y$ & $Y$ & $Y$ & $\bar{Y}$ \\
\hline E33.19 & a & a & $a$ & a & $Y$ & $Y$ & $Y$ & $Y$ \\
\hline E 33.20 & 235.57 & 405.30 & $2 / 4 / 86$ & 18.3 & $Y$ & $Y$ & $\mathbf{N}$ & $\mathbf{Y}$ \\
\hline E 33-21 & 262.82 & 400.61 & $11 / 9 / 88$ & 17.0 & $80-260^{\circ}$ & $Y$ & $Y$ & $Y$ \\
\hline E33-27 & a & a & a & a & $\mathbf{N}$ & $\mathbf{N}$ & $Y$ & $\mathbf{N}$ \\
\hline E34-1 & 223.83 & 405.59 & $3 / 31 / 88$ & 11.6 & $Y$ & $Y$ & $Y$ & $Y$ \\
\hline$E 34-2^{\circ}$ & 225.43 & 405.37 & $3 / 31 / 88$ & 15.4 & $Y$ & $Y$ & $Y$ & $Y$ \\
\hline$E 34.3^{\circ}$ & 205.53 & 405.99 & $3 / 31 / 88$ & 7.0 & $Y$ & $Y$ & $Y$ & $Y$ \\
\hline E $34.4^{\circ}$ & DAY & NR & NA & 0.0 & $Y$ & $Y$ & $Y$ & $Y$ \\
\hline E $34.5^{\circ}$ & 184.75 & 406.04 & $3 / 31 / 88$ & 4.0 & $Y$ & $Y$ & $Y$ & $Y$ \\
\hline E 34.6 & 192.53 & 405.30 & $3 / 31 / 88$ & 1.3 & $Y$ & $Y$ & $Y$ & $Y$ \\
\hline & & & & & & & & \\
\hline & & & & & & & & \\
\hline & & & & 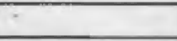 & & & & \\
\hline & & & & & & & & \\
\hline & & & & & & & & \\
\hline & & & & & & & & \\
\hline
\end{tabular}




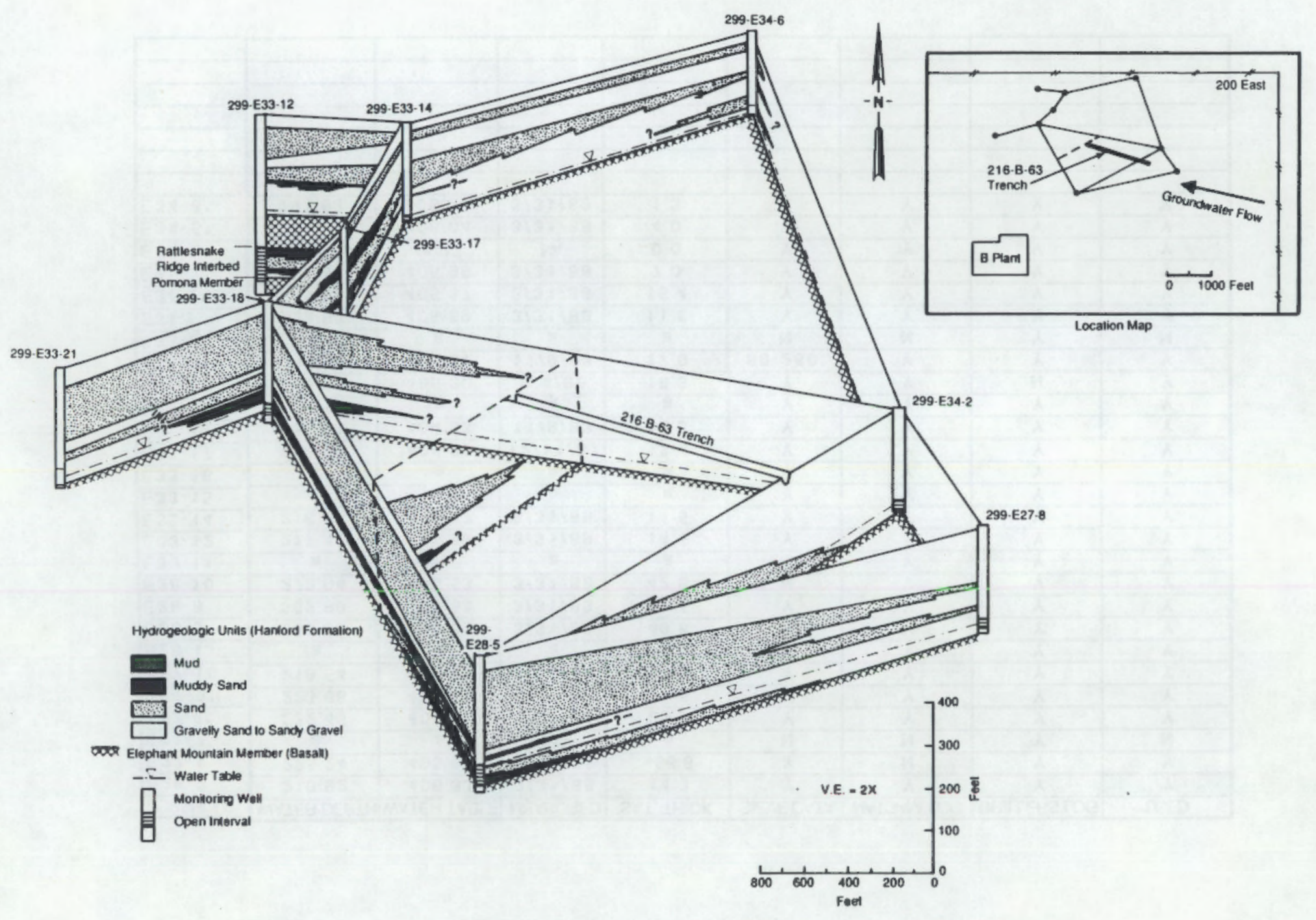

FIGURE 2.7. Fence Diagram Around the 216-B-63 Trench 


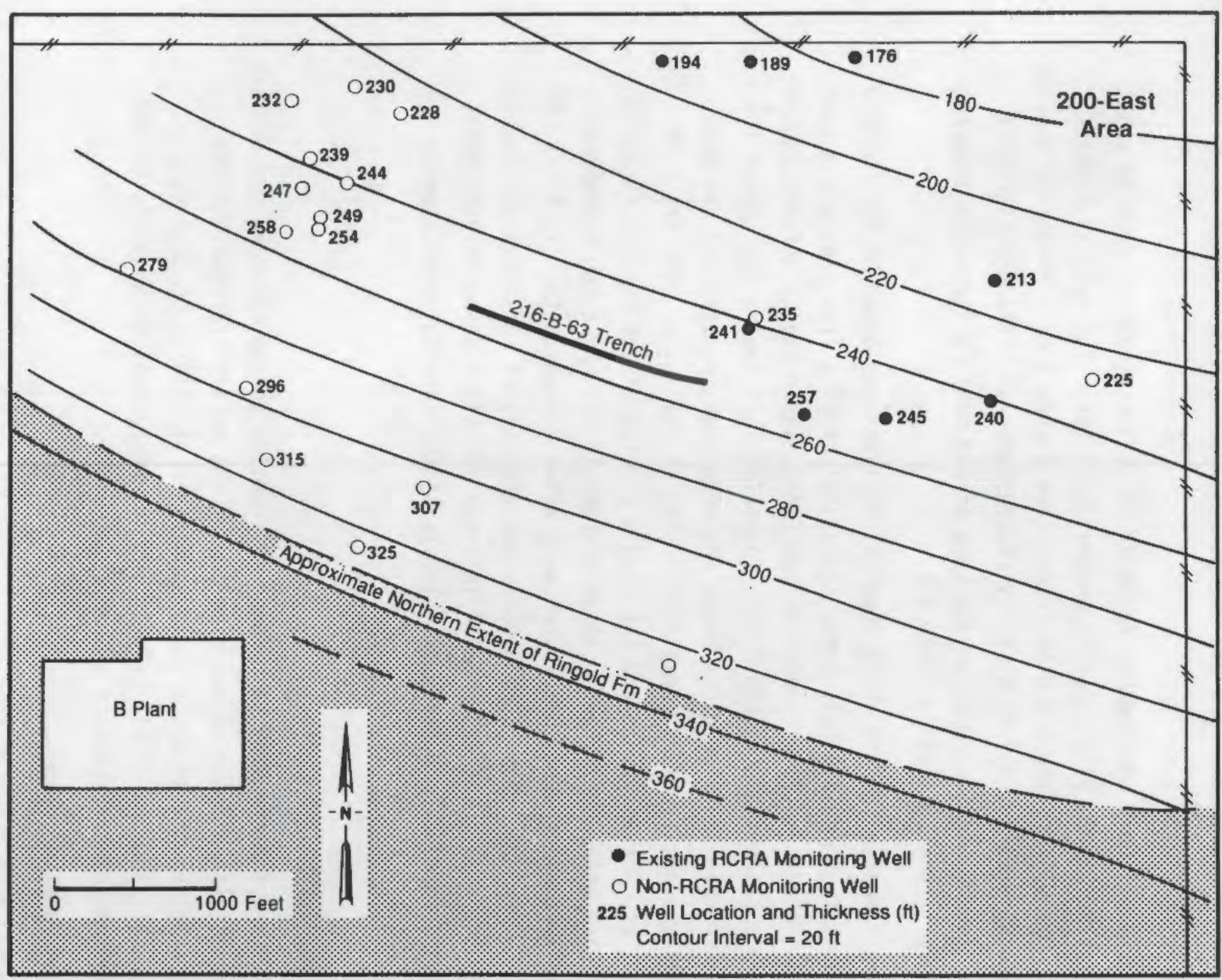

FIGURE 2.8. Isopach Map of the Post-Basalt Sediments (after Last et a1. 1989). 
the sediments overlying the basalt becomes progressively thinner to the northeast. The sediments are 250-260 ft thick beneath the trench (Figure 2.8).

Results of bulk geochemical analyses on sediment samples from an existing well (299-E34-2) have recently become available. The well is located $\sim 500 \mathrm{ft}$ northeast of the 216-B-63 trench (see Figure 2.6). Hard-tool samples from this well were analyzed by $x$-ray fluorescence at three stratigraphic levels: toward the top, middle, and base of the Hanford formation sequence. The results are tabulated in Table 2.4.

When compared to other bulk chemical analyses performed on the Hanford formation within the 200-East Area, analytical results from toward the base of the Hanford formation sequence in 299-E34-2, where the unconfined aquifer lies, are about average (Table 2.4). Concentrations toward the top of the Hanford formation, on the other hand, are more than one standard deviation above the average for many constituents ( $\mathrm{Ca}, \mathrm{Fe}, \mathrm{C}, \mathrm{Zn}, \mathrm{Ga}$, and $\mathrm{Zr}$ ). In contrast, concentrations toward the middle portion of the Hanford formation sequence are only significantly above average in $\mathrm{Ni}$, while the difference from the average is less than lo for many other elements ( $\mathrm{Ca}, \mathrm{Ti}, \mathrm{Fe}, \mathrm{V}, \mathrm{Mn}$, $\mathrm{Cu}, \mathrm{Zn}, \mathrm{Y}, \mathrm{Zr}, \mathrm{Nb})$. More bulk geochemical analyses of sediments are needed, however, to establish the degree of internal variation among stratigraphic units and determine true background levels of the chemical constituents present.

\subsection{HYDROGEOLOGY}

This section provides background information on the hydrogeology beneath the Hanford Site. Detailed descriptions of the area's hydrogeology are available in reports by DOE (1988), Gephart et a1. (1979), Graham et al. (1981, 1984), and Law et a1. (1987), and in water-level data collected and reported semiannually (Schatz and Ammerman 1988).

\subsubsection{Regional Setting}

The Hanford Site has a semiarid climate and receives an average of $6.25 \mathrm{in}$. of precipitation per year. Some evapotranspiration measurements have been made at Hanford, but a detailed study has not been made near the 
TABLE 2.4. Bulk Major- and Trace-Element Geochemistry of Sediment Samples of the Hanford Formation from Well 299-E34-2

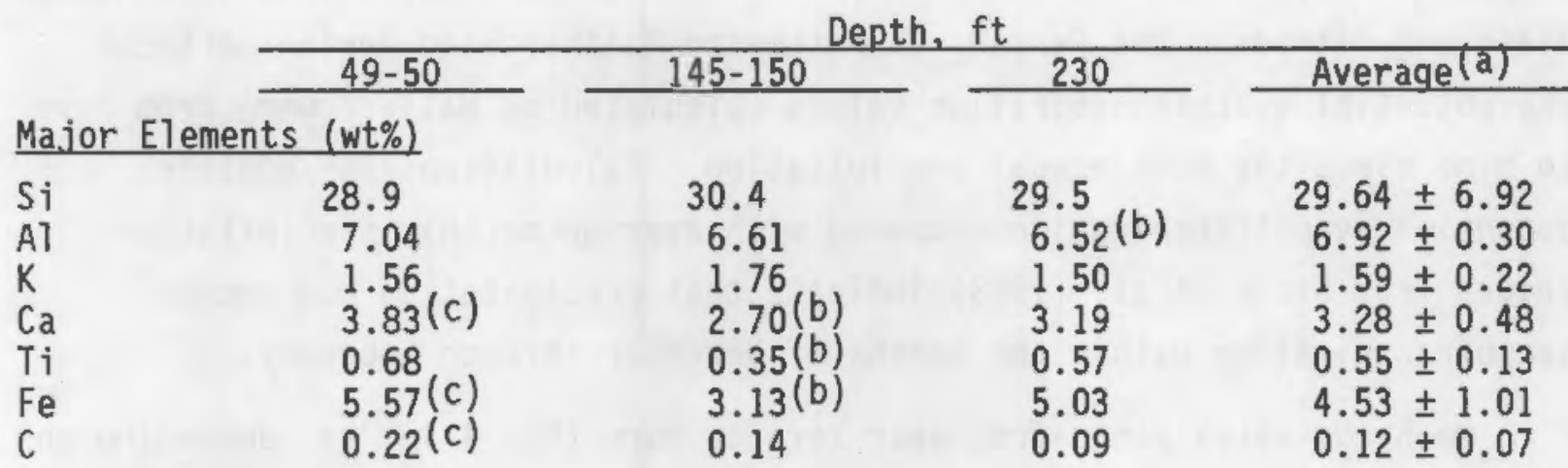

\section{Trace Elements (ppm)}

\begin{tabular}{lcccc}
\hline $\mathrm{V}$ & 229 & $92(\mathrm{~b})$ & 161 & $171 \pm 6(\mathrm{~N})$ \\
$\mathrm{Cr}$ & 30 & 55 & $<25$ & $\mathrm{NC}(\mathrm{d})$ \\
$\mathrm{Mn}$ & 901 & $618(\mathrm{~b})$ & 843 & $805 \pm 182$ \\
$\mathrm{Co}$ & $<47$ & $<34$ & $<43$ & $\mathrm{NC}$ \\
$\mathrm{Ni}$ & 18.2 & $24.7(\mathrm{c})$ & 21.4 & $20.0 \pm 3.3$ \\
$\mathrm{Cu}$ & 44.6 & $20.7(\mathrm{~b})$ & 43.5 & $37.1 \pm 15.9$ \\
$\mathrm{Zn}$ & $87.7(\mathrm{c})$ & $46.0(\mathrm{~b})$ & 72.7 & $69.7 \pm 12.8$ \\
$\mathrm{Ga}$ & $17.9(\mathrm{c})$ & 14.6 & 15.5 & $15.8 \pm 1.3$ \\
$\mathrm{As}$ & 4.42 & 4.53 & 3.79 & $4.27 \pm 0.95$ \\
$\mathrm{Se}$ & $<0.95$ & 0.99 & $<0.92$ & $\mathrm{NC}$ \\
$\mathrm{Br}$ & $<0.91$ & $<0.77$ & $<0.89$ & $\mathrm{NC}$ \\
$\mathrm{Rb}$ & 55.1 & 66.5 & 51,7 & $56.3 \pm 11.3$ \\
$\mathrm{Sr}$ & 377 & 411 & $356(b)$ & $402 \pm 37$ \\
$\mathrm{Y}$ & 26.0 & $17.7(\mathrm{~b})$ & 24.2 & $24.1 \pm 4.0$ \\
$\mathrm{Zr}$ & $158.0(\mathrm{c})$ & $106.6(\mathrm{~b})$ & 139.1 & $139.9 \pm 16.8$ \\
$\mathrm{Nb}$ & 10.76 & $7.24(\mathrm{~b})$ & 9.94 & $10.39 \pm 1.17$ \\
$\mathrm{Mo}$ & 3.02 & $<1.5$ & 2.73 & $\mathrm{NC}$ \\
$\mathrm{Ru}$ & $<4.8$ & $<4.8$ & $<4.9$ & $\mathrm{NC}$ \\
$\mathrm{Rh}$ & $<5.1$ & $<5.2$ & $<5.2$ & $\mathrm{NC}$ \\
$\mathrm{In}$ & $<6.7$ & $<7.0$ & $<6.6$ & $\mathrm{NC}$ \\
$\mathrm{Sn}$ & $<7.3$ & $<7.2$ & $<7.5$ & $\mathrm{NC}$ \\
$\mathrm{I}$ & $<12$ & $<12$ & $<12$ & $\mathrm{NC}$ \\
$\mathrm{Ba}$ & 744 & 810 & 809 & $795 \pm 84$ \\
$\mathrm{La}$ & 25 & 37 & $<22$ & $\mathrm{NC}$ \\
$\mathrm{Ce}$ & 43 & 42 & 48 & $43 \pm 11$ \\
$\mathrm{~Pb}$ & 8.0 & $<3.9$ & $<3.6$ & $9.2 \pm 1.9$ \\
$\mathrm{U}$ & $<3.9$ & & $\mathrm{NC}$
\end{tabular}

\footnotetext{
(a) Average of 13 samples of Hanford formation from 200-East Area.

(b) More than $1 \sigma$ below average of 200 -East Area samples.

(c) More than $1 \sigma$ above average of 200-East Area samples.

(d) $\mathrm{NC}=$ not calculable.
} 
Separations Areas. Wallace (1977) used Hanford Meteorology Station data to compute average potential evapotranspiration for the Hanford Site using three different methods: the Penman, Thornthwaite-Maither, and Morton methods. The potential evapotranspiration values calculated by Wallace were from five to nine times the mean annual precipitation. Calculations for monthly potential evapotranspiration compared with average monthly precipitation values from Stone et al. (1983) indicate that precipitation may exceed evapotranspiration within the months of November through February.

Recharge rates range from near zero to more than $4 \mathrm{in./yr}$, depending on surface conditions (Gee 1987). Small recharge rates occur where finetextured sediments and deep-rooted plants occur (e.g., much of the 200 Areas). The larger values are associated with areas having a coarse gravelly surface and no vegetative cover. The Hanford Site is drained by the Yakima and Columbia rivers (Figure 2.1).

Ground water beneath the Hanford Site occurs under both unconfined and confined conditions. The unconfined aquifer is contained primarily within the middle unit of the Ringold Formation and the Hanford formation. The base of the unconfined aquifer is the basalt surface of the Elephant Mountain Member of the Columbia River Basalt Group, or, in some areas, the clay of the lower Ringold unit. The confined aquifers beneath the Hanford Site include sedimentary interbeds and interflow zones that occur between dense basalt flows of the Columbia River Basalt Group.

The source of natural recharge to the unconfined aquifer and some of the confined aquifers is rainfall from areas of high relief west of the Hanford Site and ephemeral streams in the Cold Creek and Dry Creek valleys. Discharge from the unconfined aquifer is primarily to the Columbia River (Graham et a1. 1981).

\subsubsection{Ground-Water Hydrology of the Separations Areas}

As more characterization efforts are undertaken on the Hanford Site, the understanding of the geologic framework and its relation to the hydrogeologic system will continue to be developed and refined. This document does not attempt to integrate or present all that is known of the hydrogeologic system within the Separations Areas. Instead, this discussion is 1imited to 
the hydrologic properties of the uppermost portion of the unconfined aquifer contained in the Hanford and Ringold formations.

In addition to natural recharge, the unconfined aquifer receives artificial recharge from liquid disposal areas. This artificial recharge is estimated to be 10 times greater than natural recharge (Graham et al. 1981). Graham et al. estimated natural recharge from Cold Creek Valley to the Separations Areas to be approximately $1.3 \times 10^{6} \mathrm{gpd}$. The total volume of artificial recharge in 1987 was approximately $6.1 \times 10^{9}$ gal (Serkowski et al. 1988), corresponding to a rate of approximately $1.7 \times 10^{7} \mathrm{gpd}$. The major sources of artificial recharge in the central Hanford Site have been three waste ponds, designated U Pond, Gable Mountain Pond, and B Pond, all located near or in the Separations Areas. These sources of artificial recharge have had a major effect on the flow system of the unconfined aquifer. $U$ Pond and Gable Mountain Pond were deactivated in 1984 and 1987, respectively. B Pond is scheduled for decommissioning in the mid-1990s.

Ground-water elevation contours for December 1987 (Schatz and Ammerman 1988) for the unconfined aquifer in the Separations Areas are shown in Figure 2.9. The regional flow direction in the Separations Areas is from west to east, but it is affected by the two ground-water mounds that have resulted from discharges to $U$ Pond and B Pond. Ground-water flow beneath the 200-West Area is generally toward the north and east, away from the mound created by past discharges to $U$ Pond. As this mound dissipates as a result of the discontinuance of discharge to $U$ Pond, the hydraulic gradient will decrease and shift to the east. The hydraulic gradient in the 200-West Area is sufficiently high (a minimum of approximately $10^{-3} \mathrm{ft} / \mathrm{ft}$ ) to determine flow directions with a large degree of certainty. Vertical hydraulic gradients are presumed to be present within the unconfined aquifer in portions of the 200West Area as a result of the ground-water mound (Graham et a1. 1981).

Ground-water flow beneath the 200-East Area is complex because flow converges from the west and east and then diverges, with a component flowing northward between Gable Butte and Gable Mountain and the other component flowing southeast toward the Columbia River. In addition, the high transmissivity beneath most of the 200 -East Area results in very small hydraulic 
gradients. Flow directions may shift because of changing rates of waste water discharged into B Pond and other disposal sites. Therefore, it is often difficult to define flow directions at specific sites.

The principal geologic units (Figure 2.5) controlling ground-water flow in the Separations Areas are, in ascending order, the Elephant Mountain Member, which acts as a confining layer except where it has been locally eroded, and the Ringold and Hanford formations, which contain the unconfined aquifer. Basalt of the Elephant Mountain Member is assumed to be the base of the unconfined or uppermost aquifer near the 200-East Area. However, two studies (Graham et al. 1984; Jensen 1987) present results indicating aquifer intercommunication between the unconfined aquifer and the Rattlesnake Ridge confined aquifer near the 200-East Area. The Elephant Mountain Member has possibly been eroded in or near the northeast corner of the 200-East Area, providing a means for aquifer intercommunication.

The depth to water of the unconfined aquifer within the Separations Areas ranges from approximately $19 \mathrm{ft}$ beneath the former $U$ Pond to approximately $340 \mathrm{ft}$ west of the 200 -East Area. The thickness of the unconfined aquifer ranges from $0 \mathrm{ft}$ at the north edge of the 200-East Area to more than $250 \mathrm{ft}$ in the northwest part of the 200 -West Area.

In general, the transmissivity tends to increase from west to east across the Separations Areas as a result of a larger portion of the unconfined aquifer being contained within the more permeable Hanford formation.

The Ringold Formation exhibits a variety of hydrologic characteristics, including hydraulic conditions ranging from confined to unconfined. In some areas, the lower Ringold unit is the base of the unconfined aquifer. In the southern portion of the 200-East Area and much of the 200-West Area, the basal Ringold unit is locally confined by the overlying lower Ringold unit (Graham et al. 1984). In other areas, the lower Ringold unit is missing, and the basal and middle Ringold units contain the unconfined aquifer. In the northeastern portion of the 200-East Area, the Ringold Formation is completely eroded. Here, the unconfined aquifer lies within the Hanford formation, which lies directly on top of basalt (Tallman et al. 1979). The lithologies in the unconfined aquifer exhibit widely varying hydrogeologic 


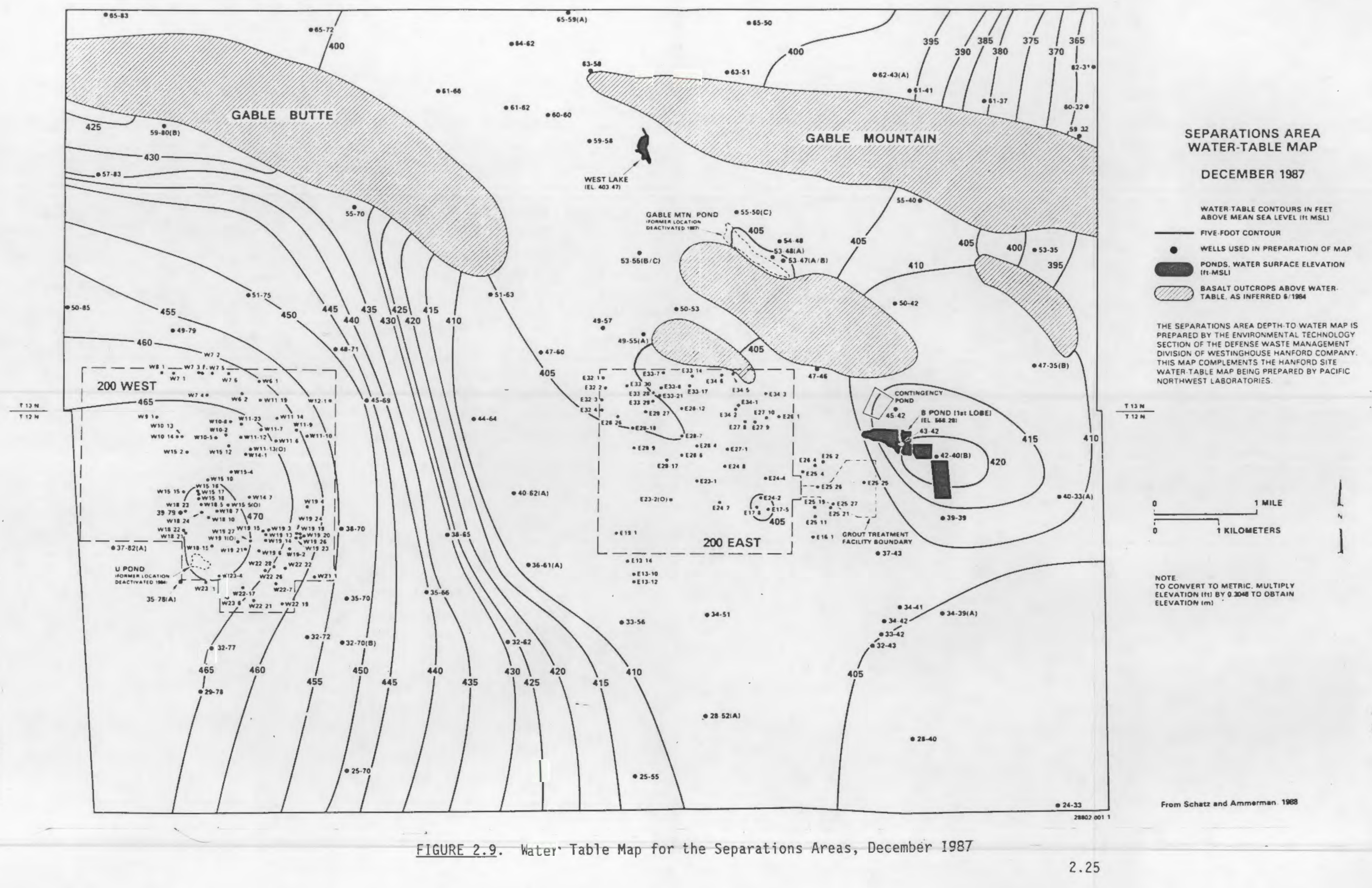



properties (Table 2.5). The values given in this table are generalizations; in some locations hydraulic properties lie beyond the ranges given.

In the 200-West Area, the unconfined aquifer occurs within the middle Ringold unit, which is compacted and often partially cemented. Transmissivities range from 300 to $5400 \mathrm{ft}^{2} / \mathrm{d}$. In the 200-East Area, the aquifer is in either the unconsolidated Hanford formation, the middle Ringold unit, or both, leading to a range of transmissivities from 5 to $135,000 \mathrm{ft}^{2} / \mathrm{d}$ (Graham et a1. 1981).

The measured storativity values for the unconfined aquifer range from 0.002 to 0.7 (Table 2.5); the lower values are associated with the lower Ringold unit and the higher values with the Hanford formation (Graham et al. 1981).

The effective porosity of the sediments in the unconfined aquifer ranges from 10 to $30 \%$. The lower value can be correlated with sediments of the lower Ringold unit, and the upper range approaches the total porosity of the sediments in the Hanford formation (Graham et al. 1981). The water in the aquifer is principally of a calcium-bicarbonate type, but there is considerable variability in chemical composition among individual samples.

Discontinuous perched-water tables occur in parts of the 200-West Area, often lying above a calcrete belonging to the Plio-Pleistocene unit or above markedly finer-grained sediments in the upper Ringold and Hanford formations. The lateral extent of these perched-water tables has not been defined in

TABLE 2.5. Ranges of Hydraulic Properties in the 200-East Area Hydraulic Conductivity

Interval Tested $(\mathrm{ft} / \mathrm{d})$ Hanford Formation 2, $000-10,000$

Storativity

0.07

9-230

1-12

0.002
Porosity (\%)

30

10

Source: Graham et al. 1981. 
detail, but they are generally found only near sources of discharge of large quantities of water to the sediment column and where fine-grained sediments occur.

\subsubsection{Hydrogeology Beneath the Site}

The unconfined aquifer lies at a depth of about $240 \mathrm{ft}$ (Figure 2.10) beneath the site. The aquifer thins to the northeast in response to the sloping basalt surface, which is folded upward in this direction (Figure 2.11). The thickness of the unconfined aquifer ranges from about 20 to $30 \mathrm{ft}$ in the vicinity of the trench (Figure 2.12). The aquifer lies entirely within the coarse-grained Hanford formation deposits, except south of the trench (e.g., 299-E28-5) where slack-water deposits of sand to muddy sand 1 ie within the aquifer (see Figure 2.7) Discontinuous fine-grained layers of sand and mud occur above the water table also, but these appear to be restricted to areas south and west of the trench.

Near the 216-B-63 trench, aquifer tests have been performed on wells associated with the Low-Level Burial Ground waste management area, located north and east of the trench (Last et al. 1989). Results of these tests, performed on two wells within $1000 \mathrm{ft}$ of the trench (299-E27-8 and 299-E34-2), along with estimated aquifer thickness and calculated hydraulic conductivity, are presented in Table 2.6.

Based on the potentiometric map in Figure 2.13, ground water flows west-northwest, roughly parallel to the axis of the 216-B-63 trench. The ground-water flow is driven in this direction by the recharge mound beneath $B$ Pond to the east (Figure 2.9). The differences in head are relatively minor, however, and the flow of ground water could change significantly after $B$ Pond is decommissioned. 


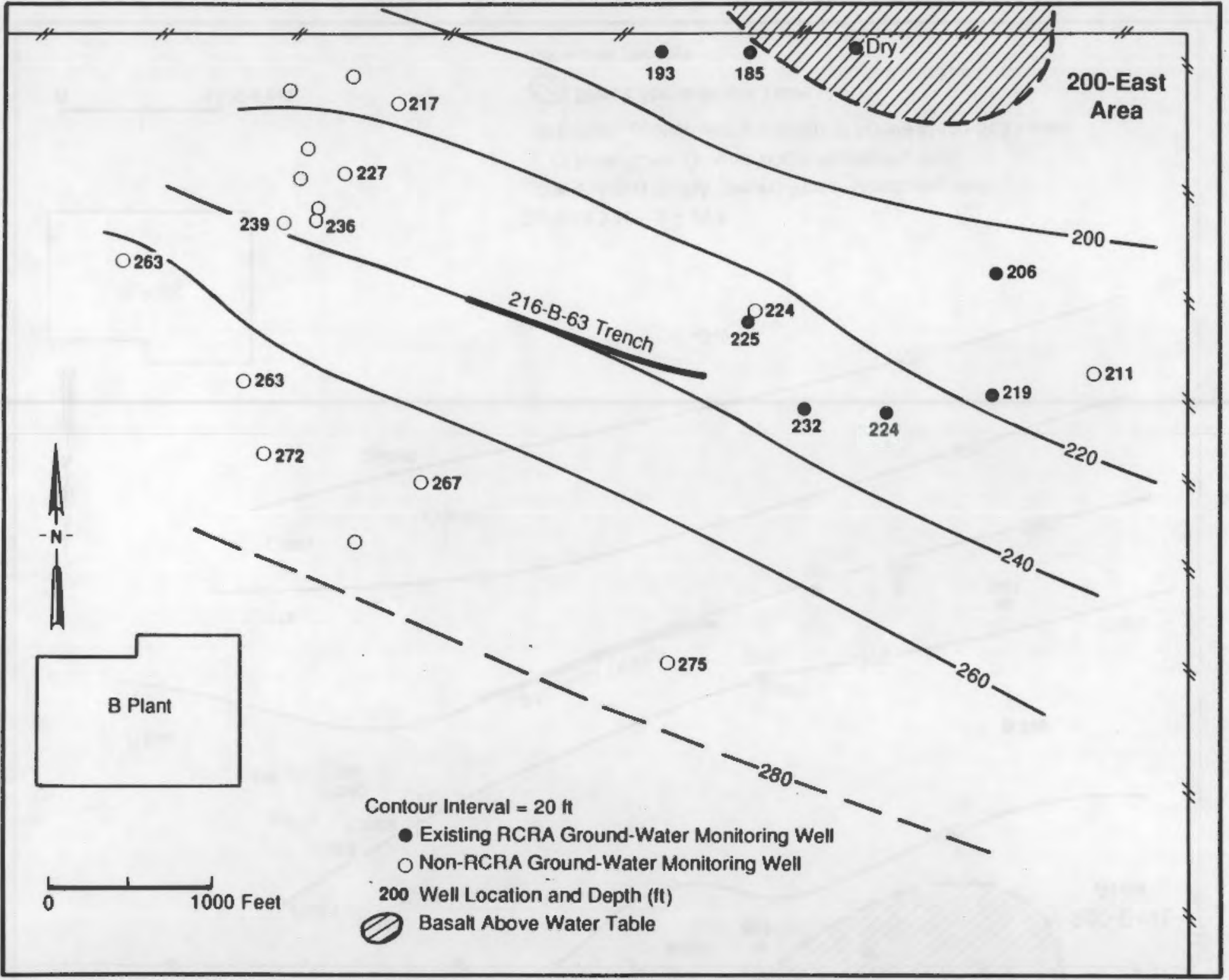

FIGURE 2.10. Depth to the Water Table in the Vicinity of the 216-B-63 Trench, March 1988 


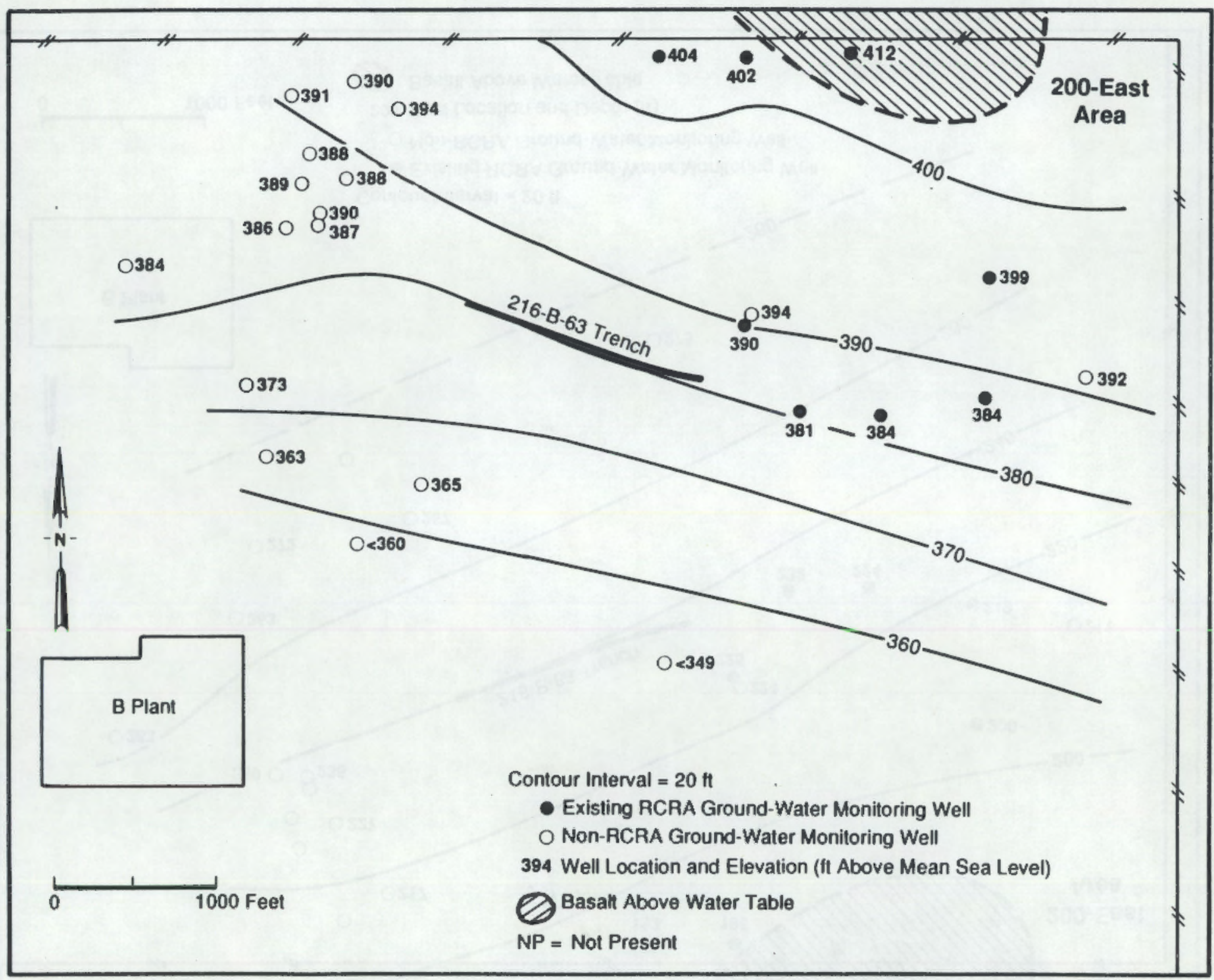

FIGURE 2.11. Base of Unconfined Aquifer (top of basalt) in the Vicinity of the 216-B-63 Trench 


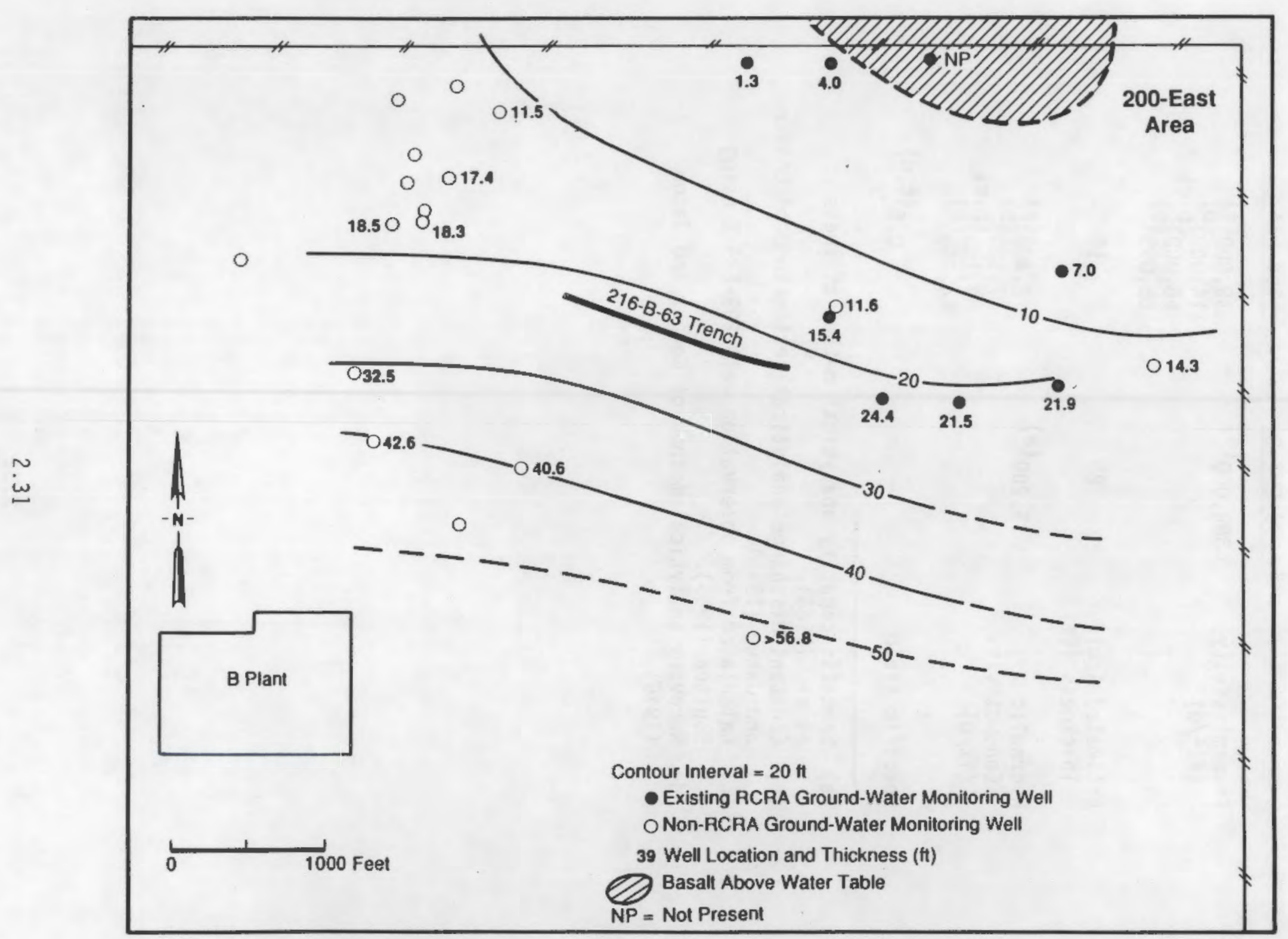

FIGURE 2.12. Saturated Thickness of the Unconfined Aquifer in the Vicinity of the 216-B-63 Trench, March 1988 
TABLE 2.6. Hydraulic Properties From Wells Near the 216-B-63 Trench (from Last et al. 1989)

\begin{tabular}{|c|c|c|}
\hline & 299-E27-8 & 299-E34-2 \\
\hline $\begin{array}{l}\text { Transmissivity } \\
\left(\mathrm{ft}^{2} / \mathrm{d}\right)\end{array}$ & $380,000^{(a)}$ & $\begin{array}{c}39,000(\mathrm{a}) \\
114,000(\mathrm{~b}) \\
66,000(\mathrm{~b}, \mathrm{c}) \\
85,000(\mathrm{~d})\end{array}$ \\
\hline $\begin{array}{l}\text { Estimated Aquifer } \\
\text { Thickness ( } \mathrm{ft} \text { ) }\end{array}$ & 25 & 16 \\
\hline $\begin{array}{l}\text { Hydraulic } \\
\text { Conductivity } \\
(\mathrm{ft} / \mathrm{d})\end{array}$ & $15,200^{(a)}$ & $\begin{array}{l}2,400(\mathrm{a}) \\
7,100(\mathrm{~b}) \\
4,100(\mathrm{~b}, \mathrm{c}) \\
4,250^{(\mathrm{d})}\end{array}$ \\
\hline Specific Yield & $\cdots$ & $0.5^{(c, d)}$ \\
\hline
\end{tabular}

(a) Specific-capacity analytical method of Theis et al. (1963).

(b) Constant discharge analytical test method of Cooper and Jacob (1946).

(c) Calculated from observation we11 299-E34-1 using Boulton (1963).

(d) Recovery analytical method of Cooper and Jacob (1946). 


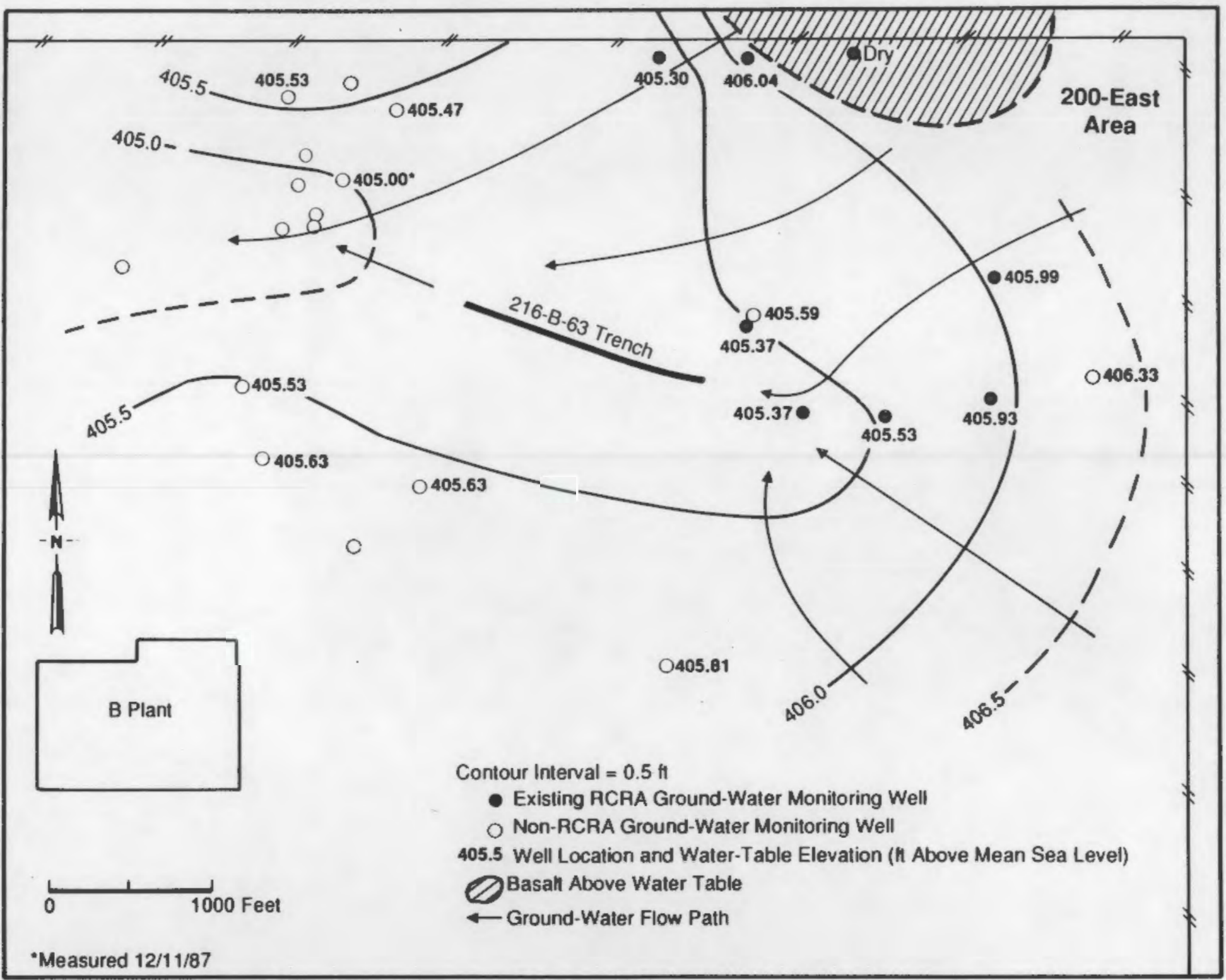

FIGURE 2.13. Water-Table Surface and Directions of Ground-Water Flow in the Vicinity of the 216-B-63 Trench, March 1988 



\subsection{PHASE 1. GROUND-WATER MONITORING PROGRAM}

This $\mathrm{plan}$ has been developed in accordance with RCRA, as described by 40 CFR Part 265, Subpart F, and Ecology (1986) to establish a ground-water monitoring plan for an indicator-evaluation program for the 216-B-63 trench and, if necessary, to initiate an ground-water quality assessment program.

\subsection{OBJECTIVES}

The objectives of the ground-water monitoring program for the 216-B-63 trench are to:

- Characterize the sedimentary deposits and the ground-water flow direction and rate beneath the trench. The focus will be on the unconfined aquifer.

- Implement a monitoring program to determine if statistically significant amounts of hazardous waste constituents above background occur in the ground water downgradient from the trench.

- Initiate, if necessary, the development of an assessment-level monitoring program to determine the nature and extent of contamination from the trench.

\subsection{APPROACH}

The initial indicator-evaluation ground-water monitoring network for the 216-B-63 trench will utilize eight wells (Figure 3.1). Two wells already in existence (299-E27-8 and 299-E-34-2) will be used as upgradient wells to establish background concentrations of constituents. Four new wells will be drilled, via the cable-tool method, west and south of the trench to serve as detection wells. Three additional we11s (2-D1, 2-D3, and 2-D4) are planned but not yet installed immediately north of the trench to monitor one of the Low-Level Burial Ground waste-management areas (Last et al. 1989). Depending on the direction of ground-water flow, these wells may also be utilized for detection of contaminants from the 216-B-63 trench. A11 eight monitoring wells will penetrate into the top of basalt.

As part of characterization, subsurface soil samples will be obtained every $5 \mathrm{ft}$ or at major changes in lithology during drilling at each location. 


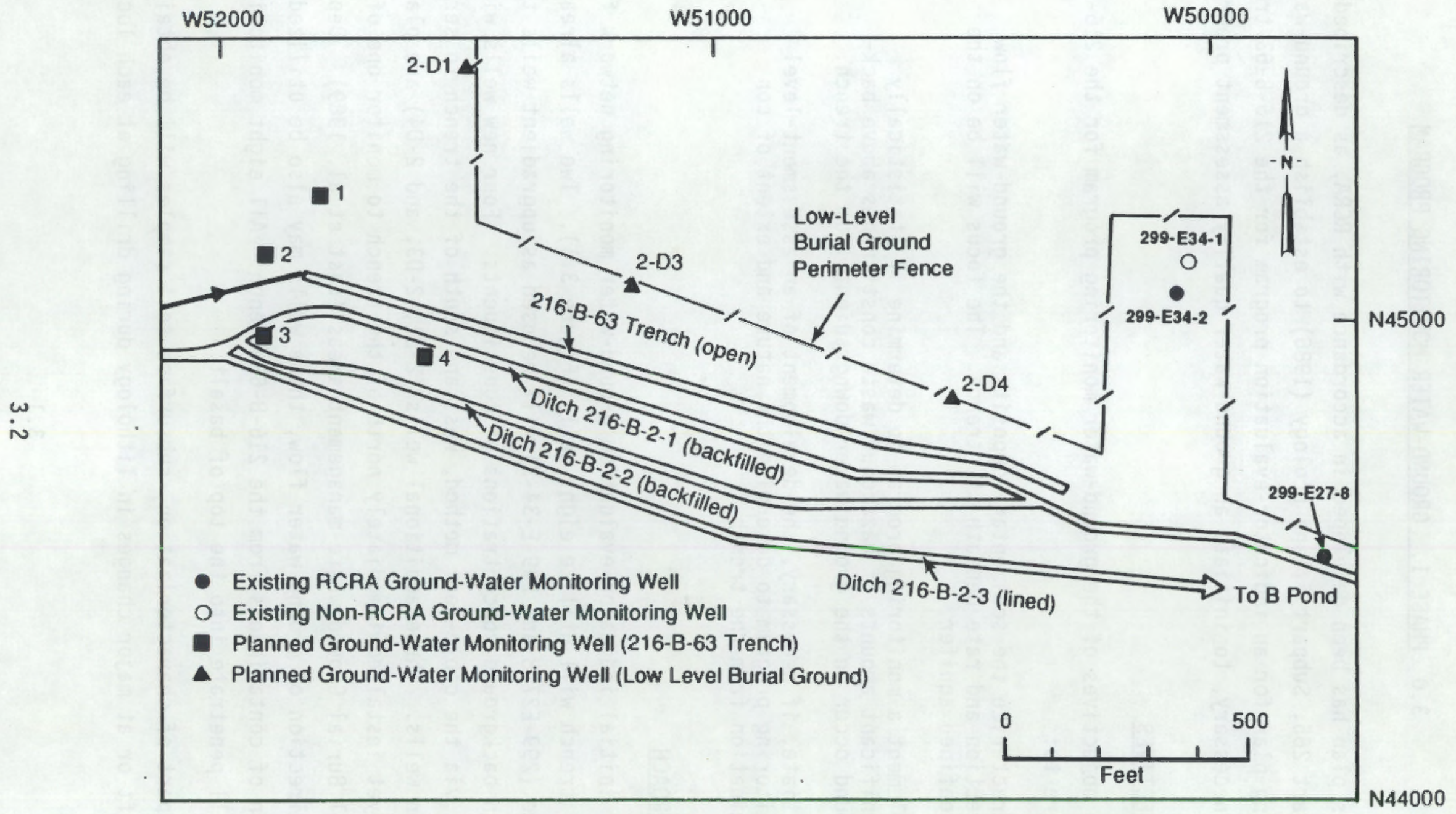

FIGURE 3.1. Existing and Planned Wells Near the 216-B-63 Trench 
Detailed descriptions of these samples will be made at the drill site and summarized on lithologic logs. Samples will be collected, where appropriate, for grain-size analysis, moisture content, and/or other physical and chemical properties. Ground-water samples will be collected when drilling reaches the water table. These samples will be analyzed for contamination indicator parameters (noted later in this section) before aquifer testing. If contamination is not detected, aquifer tests will be conducted to provide estimates of transmissivity and hydraulic conductivity of materials beneath the site. Each of the monitoring wells will be tested geophysically with a natural gamma $\log$, once for each different size casing and again upon final well completion.

Ground water within the new wells, plus that in appropriate existing wells, will be monitored at approximately 3-month intervals in order to establish background levels. After one year, sampling will occur semiannually to look for statistically significant changes in water quality and/or ground-water flow. If contamination is detected, then an assessmentlevel monitoring program, outlined in Chapter 4.0 of this document, will be implemented.

Procedures to be used during this ground-water investigation appear in PNL (1989). The most recent versions of procedures will be followed; periodic updates of procedures will appear.

\subsection{GROUND-WATER MONITORING SYSTEM}

This section discusses the indicator-evaluation ground-water monitoring system, including locations and justifications for new wells, drilling and well installation, planned ground-water monitoring, and the types of indicator parameters to be monitored.

\subsubsection{Uppermost Aquifer}

The uppermost aquifer beneath the 216-B-63 trench is the unconfined aquifer, discussed previously in Section 2.3.3. The unconfined aquifer lies at a depth of about $240 \mathrm{ft}$ beneath the trench (see Figure 2.10). At the present time there is no evidence to suggest the presence of any perched water in the immediate vicinity of the trench. The unconfined aquifer is 
absent northeast of the 216-B-63 trench where the top of the basalt rises above the surface of the water table (Figure 2.12). The unconfined aquifer is only about 20-30 ft thick in the vicinity of the trench, but it becomes progressively thicker to the southwest.

Very few wells are located near the 216-B-63 trench. Only one well (299-E34-2) is within $500 \mathrm{ft}$, and only three wells lie within $1000 \mathrm{ft}$ of the trench. For this reason it is not possible to evaluate the detailed geology and hydrology of the area immediately adjacent to the trench with available information. Installation of the new monitoring wells is needed to better understand the geologic and hydrologic characteristics of the site.

\subsubsection{Background (Upgradient) Wells}

Under the present ground-water flow regime, the movement of ground water appears to be roughly east to west in the vicinity of the 216-B-63 trench (Figure 2.13). Two existing upgradient wells, 299-E27-8 and 299-E34-2, will serve as background wells. As discussed in Section 2.3.3, the present flow direction is primarily the result of a temporary ground-water mound that exists as a result of artificial recharge from $B$ Pond, located 1.5 mi east of the 216-B-63 trench. In the future, the ground-water flow may change direction drastically after B Pond is decommissioned in the mid-1990s. The monitoring system will be reevaluated at that time to determine whether these wells remain appropriate background wells.

\subsubsection{Detection (Downgradient) Wells}

The placement of detection-monitoring wells is complicated by the fact that the present ground-water flow direction appears to roughly parallel the trench (see Figure 2.13). Furthermore, because the data are limited, the exact direction and the degree of variation in ground-water flow are uncertain at this time.

A total of four new detection wells will be installed at the west (hydraulically downgradient) end of the 216-B-63 trench (Figure 3.1). Three of the wells are placed west of trench and the fourth is south. Three other wells located north of the trench are planned to monitor an adjacent 
waste-management area (Last et al. 1989). These wells may also be used as detection wells, depending on the direction of ground-water flow.

\subsubsection{Use of Existing Wells}

Only three existing wells lie within $1000 \mathrm{ft}$ of the 216-B-63 trench (Figure 3.1). Two of these wells, 299-E34-2 and 299-E27-8, currently monitor the uppermost aquifer and were constructed according to RCRA specifications (EPA 1986) to monitor one of the Low-Level Burial Ground waste-management areas (Last et a1. 1989). A third well, 299-E34-1, is much older and not constructed according to RCRA specifications.

Use of the two existing RCRA monitoring wells is justified for several reasons. First, their construction is identical to that of wells planned to monitor the 216-B-63 trench. Furthermore, these wells appear to lie in the present flow path of planned downgradient wells and are close $(\leq 500 \mathrm{ft})$ to the trench.

As-built diagrams and geohydrologic information for all three existing wells are presented in Appendix A.

\subsubsection{Installation of New Characterization/Monitoring Wells}

Four new wells are planned to monitor the 216-B-63 trench. Planned well locations and depths of these wells are presented in Table 3.1. The purpose of these wells is to 1) provide downgradient ground-water quality information from the upper portion of the unconfined aquifer, 2) provide a means of evaluating the hydraulic properties of the aquifer, 3) provide information needed to define the subsurface stratigraphy beneath the site, and 4) provide samples to determine the moisture content of the unsaturated zone.

Because the unconfined aquifer is relatively thin (20-30 ft) in the vicinity of the 216-B-63 trench, all four wells will be drilled into the uppermost basalt flow (Elephant Mountain Member). Total depths should be within the range from 255 to $265 \mathrm{ft}$. Drilling to basalt will allow aquifer testing of the full saturated thickness of the unconfined aquifer. Furthermore, these wells will provide information on the hydrostratigraphic units, direction of ground-water flow, and water quality within the unconfined. aquifer. 
IABLE 3.1. Planned Well Locations and Depths for the 216-B-63 Trench

\begin{tabular}{|c|c|c|c|c|c|}
\hline $\begin{array}{l}\text { Well } \\
\text { No. } \\
\end{array}$ & Type of Well & $\begin{array}{c}\text { Approximate } \\
\text { Location } \\
\text { (Hanford } \\
\text { Coordinates) }\end{array}$ & $\begin{array}{c}\text { Approximate } \\
\text { Depth to } \\
\text { Water (ft) }\end{array}$ & $\begin{array}{l}\text { Approximate } \\
\text { Depth of } \\
\text { Borehole (ft) }\end{array}$ & $\begin{array}{l}\text { Length } \\
\text { of } \\
\text { Screen } \\
\text { (ft) }\end{array}$ \\
\hline 1 & Shallow monitoring & $\begin{array}{l}\text { N45250 } \\
\text { W51780 }\end{array}$ & 235 & 255 & 15 \\
\hline 2 & Shallow monitoring & $\begin{array}{l}\text { N45150 } \\
\text { W51900 }\end{array}$ & 240 & 260 & 15 \\
\hline 3 & Shallow monitoring & $\begin{array}{l}\text { N44990 } \\
\text { W51890 }\end{array}$ & 245 & 265 & 15 \\
\hline 4 & Shallow monitoring & $\begin{array}{l}\text { N44910 } \\
\text { W51560 }\end{array}$ & 245 & 265 & 15 \\
\hline
\end{tabular}

\subsubsection{Justification for Locations}

Locations of the new wells are along the western end of the 216-B-63 trench (Figure 3.1). Three of the wells (\#1,2, and 3) are located west of the trench in order to provide the minimum number of detection wells required (three) in the case where ground-water flow is parallel to the trench, as it appears to be. However, because water-level data in the vicinity of the trench are limited, the true flow direction may not be exactly parallel to the trench; it may instead be at a slightly acute angle to the trench. If this is the case, then either well \#4, located south of the trench, or the planned wells 2-D1 and/or 2-D3 north of the trench can serve as detection wells.

In order to prevent excessive dilution of contaminants by the ground water (EPA 1986), the wells will be placed close to the trench. Each of the four wells is planned to be located within $200 \mathrm{ft}$ of the trench, for the following reasons: As liquid wastes move vertically through the vadose zone, the contaminant plume will spread laterally. This spreading will be greatest atop aquitards and/or along lithologic contacts between sediments of differing particle-size distribution. Initial moisture analyses from samples 
and chemical monitoring during drilling at the $216-\mathrm{A}-36 \mathrm{~B}$ crib indicates that this lateral spreading has occurred at least $100 \mathrm{ft}$ from the crib but not as far as $200 \mathrm{ft}$ from the crib.

The final and exact locations of the monitoring wells are contingent upon their ability to not interfere with underground or overhead utilities, any nearby burial sites, or potential high-contamination zones.

Problems may result with the installation of wells \#3 and 4 because of their proximity to the backfilled ditches that parallel the 216-B-63 trench (see Figure 3.1). Any new wells drilled in this area will be closely surveyed and monitored with respect to past waste-management operations. The history of these ditches has been summarized by Maxfield (1979).

The 216-B-2-1 ditch, the ditch closest to the 216-B-63 trench, was an unlined trench $15 \mathrm{ft}$ wide at ground level, $6 \mathrm{ft}$ deep, and approximately $3500 \mathrm{ft}$ long. The ditch, which received B Plant process cooling water from April 1945 to November 1963, was backfilled in 1964 after a radioactive leak occurred. The leak resulted in the gross contamination of the head end of the 216-B-2-1 ditch with cerium-rare earth fission products (principally cerium-144). The contaminated surface of the ditch was either scraped clean or covered with clean soil. When plants growing over the buried ditch were found to be contaminated in 1969-1970, a 10-mi1-thick layer of plastic sheeting $32 \mathrm{ft}$ wide and $2400 \mathrm{ft}$ long was placed above the trench as a root barrier. Then approximately $18 \mathrm{in.}$ of sand followed by $4 \mathrm{in}$. of gravel were placed over the plastic sheeting.

A new ditch, 216-B-2-2, was dug parallel to the 216-B-2-1 ditch when the older ditch was abandoned. Like the original ditch, the 216-B-2-2 ditch was also an unlined trench approximately $15 \mathrm{ft}$ wide at ground level, 6-8 ft deep, and $3500 \mathrm{ft}$ long and designed to transport water from B Plant to the 216-B-3 pond. The trench was abandoned in March 1970 after an estimated 1000 curies of strontium-90 were accidentally released from B Plant to the 216-B-2-2 ditch and 216-B-3 pond. Like the older ditch, the 216-B-2-2 ditch was covered to ground level and a similar root barrier emplaced over the first $2400 \mathrm{ft}$ of the buried length of the ditch. Cooling water from B Plant was subsequently diverted to the 216-B-2-3 ditch currently in use. 


\subsubsection{Drilling and Well Installation}

A schematic diagram of a completed ground-water monitoring well is presented in Figure 3.2. Procedures concerning geologic sampling and inspection of well construction are given by Last and Liikala (1987) and PNL (1989). The wells will be drilled with the cable-tool drilling method. Cable-tool drilling is desirable because 1) drill cuttings are easily contained (important in contaminated material), 2) moderately to well representative geologic samples can be collected, 3) moisture samples can be collected from above the water table using drive-barrel techniques, 4) disturbance to the borehole wall is minimized, 5) a straight and plumb borehole is produced, and 6) the borehole can be kept open until final construction.

The drive-barrel method of sampling is the preferred method for the unsaturated sediments, because it provides relatively intact and representative geologic samples in comparison with the hard-tool method, which tends to pulverize and mix the sediments. Both above and below the water table, split-barrel samples, which provide the most representative samples, may be collected occasionaliy to provide samples for permeameter and bulk porosity testing.

Sediment samples collected during drilling will be monitored periodically for radioactive and hazardous contamination. If the sediments are contaminated, they will be handled, contained, transported, and disposed of in accordance with existing Westinghouse Hanford procedures.

Temporary carbon-steel casing will be driven to the well's total depth as each borehole is advanced. When the water table is reached, ground-water samples will be collected and the following contamination indicator parameters will be analyzed after sampling: 1) total organic carbon, 2) gross alpha, 3) gross beta, 4) gamma scan, 5) nitrate, and 6) iodine-129. In addition, manganese, chromium, nickel, and iron will be analyzed to determine baseline chemistry conditions for these constituents before beginning we11completion activities.

If concentrations of the first set of six constituents exceed the limits stated in the Effluent Monitoring Plan, which will be written before 


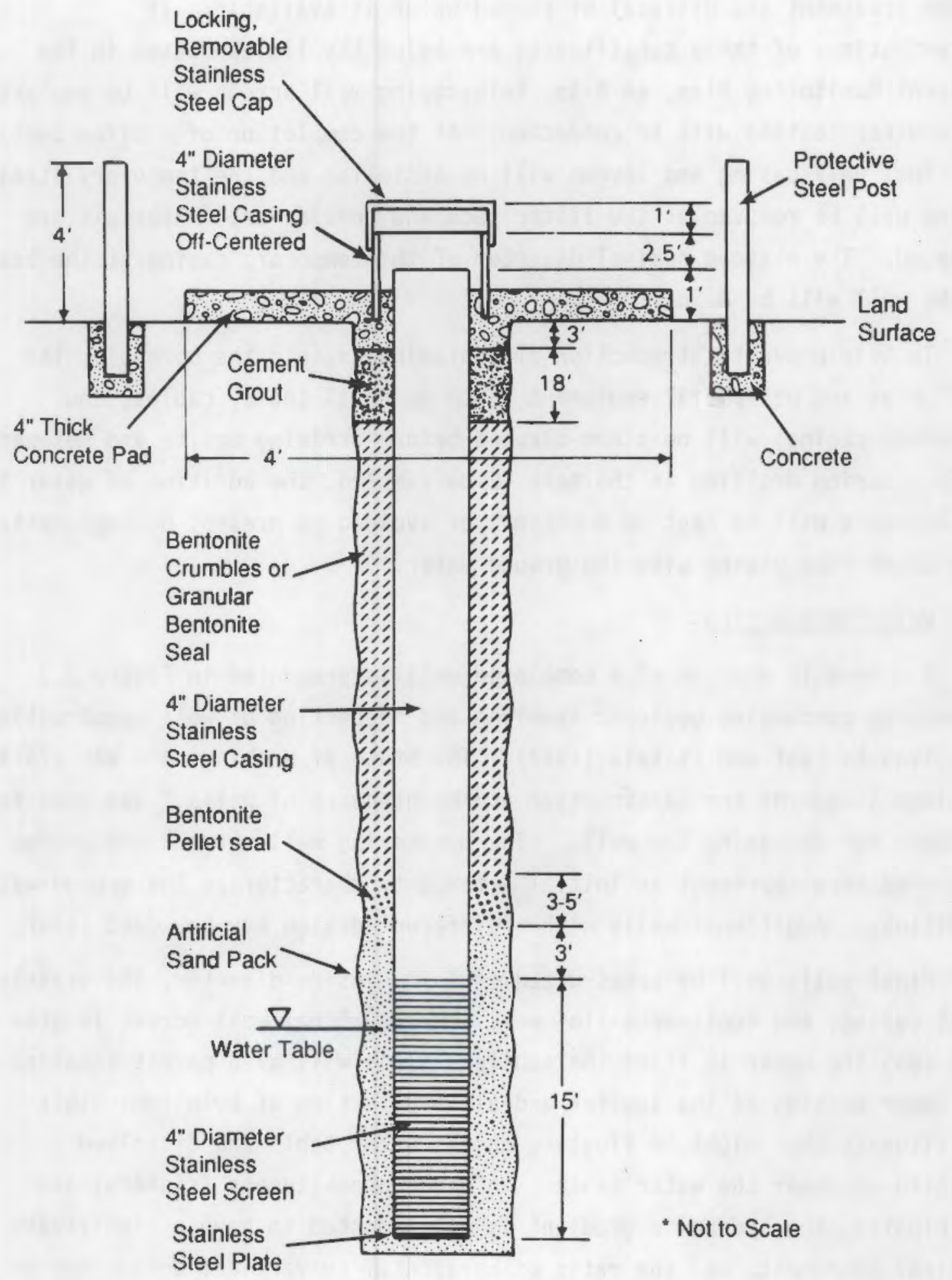

FIGURE 3.2. Schematic Diagram of a Completed Ground-Water Monitoring Well 
hydrologic testing begins, aquifer testing will not be conducted until proper treatment and disposal of pumped water is available. If concentrations of these constituents are below the limits stated in the Effluent Monitoring Plan, an 8-in. telescoping well screen will be emplaced and aquifer testing will be conducted. At the completion of aquifer testing, the final well casing and screen will be installed and the temporary steel casing will be removed as the filter pack and annular seal materials are emplaced. The minimum nominal diameter of the temporary casing at the bottom of the well will be 8 in.

To help prevent introduction of contaminants into the borehole, the drill rigs and peripheral equipment (such as drill tools, cables, and temporary casing) will be steam-cleaned before arriving onsite and between wells. During drilling in the zone to be sampled, the addition of water to the borehole will be kept to a minimum or avoided to prevent nonrepresentative water from mixing with the ground water.

\section{Well Construction}

A schematic diagram of a completed well is presented in Figure 3.2. Procedures concerning geologic sampling and inspection of well construction are given by Last and Liikala (1987). The State of Washington's WAC 173-160, "Minimum Standards for Construction and Maintenance of Wells, " was used for guidance for designing the wells. The monitoring well network and design presented here represent an initial attempt to characterize the ground-water conditions. Additional wells with a different design may be added later.

Final wells will be constructed of 4-in.-inside-diameter, 304 stainlesssteel casing, and continuous-slot well screen. Final well screen lengths will span the upper $15 \mathrm{ft}$ of the aquifer. This will also permit sampling of the upper portion of the aquifer and allow detection of both immiscible constituents that might be floating on the water table and dissolved constituents near the water table. No dense constituents (sinkers) are anticipated, the hydraulic gradient is not expected to have a significant vertical component, and the ratio of horizontal to vertical anisotropy is greater than 10 (Graham et a1. 1981). The width of the screened interval will allow for possible future fluctuations of the unconfined aquifer from 
varjations in discharges to B Pond. The botton of the screened interval will lie approximately 5-15 ft above the base of the aquifer (i.e., the top of basalt). This will allow detection of constituents near the bottom of the unconfined aquifer. The screen length will be limited to $15 \mathrm{ft}$ to minimize excessive dilution of the samples.

A 10-slot screen is expected to be used for the wells at the 216-B-63 trench. The onsite geologist will determine the filter pack size and screen slot size based on guidelines outlined by Last and Liikala (1987). Sand filter packs will be placed in the annulus between the 8-in. telescoping screen or the temporary (8-in.) casing and the permanent (4-in.) casing and screen as the temporary casing is withdrawn. If a telescoping screen is used during the shallow well aquifer tests, it will be left in the hole. The sand filter pack will be placed from total well depth to approximately $3 \mathrm{ft}$ above the top of the screen, except where the well is drilled to a depth deeper than the screened depth. In wells drilled more than $2 \mathrm{ft}$ below screen depth, bentonite will be placed from the total depth of the borehole to $2 \mathrm{ft}$ below the bottom of the screen.

A 2- to 3-ft-thick bentonite pellet seal will be placed on top of the sand pack. The annulus between the bentonite pellet seal and $18 \mathrm{ft}$ below ground surface will be filled with bentonite. Cement grout will then be installed to within $2 \mathrm{ft}$ of the ground surface. The well casing will extend 1 to $2 \mathrm{ft}$ above ground surface and will be protected by an outer steel casing and a locking cap. The casing will be set into the ground and cemented in place with a 4-ft by 4 -ft concrete well pad. All protective casings will be permanently marked with well identification numbers.

Well Development

All wells will be developed following completion. Development water wi1l be monitored and handled according to an Effluent Monitoring Plan, which will be prepared before water is removed from the well. Wells will be developed by surge-and-bail technique, overpumping, or any other techniques deemed necessary unti1 turbidity is less than 5 NTU and sediment content is less than $8 \mathrm{mg} / \mathrm{L}$. If the water cannot be developed to a turbidity of less than 5 NTU, an explanation will be documented by a qualified hydrogeologist. 
Other hydrochemical indicators, such as total iron and drilling fluid tracers will be monitored to assess the adequacy of development pumping for trace constituent sampling.

\section{Surveying}

After monitoring well installation is completed, all wells will be surveyed for location and elevation by qualified surveyors. The elevation of the top of the stainless-steel casing and a brass marker in the concrete pad will be determined within $0.04 \mathrm{ft}$. A mark will be placed on the casing to indicate the location that was surveyed. The areal location will be determined to the nearest $0.5 \mathrm{ft}$. All measurements will be referenced to a common datum (preferably a Hanford Site datum).

\subsubsection{Monitoring Parameters}

Ground-water samples will be collected during each quarter at a minimum for the constituents listed in Table 3.2. Monitoring of these constituents is required by 40 CFR Part 265, Subpart $F$. In addition, constituents from the long list in Appendix $C$ will be analyzed once during the first year of sampling.

\subsection{HYDROGEOLOGIC CHARACTERIZATION}

Hydrogeologic characterization will be conducted to describe the geologic and hydrogeologic conditions and properties that control contaminant flow paths. Work performed will follow approved procedures, in accordance with a Quality Assurance Project P1an approved by PNL and Westinghouse Hanford that meets U.S. Environmental Protection Agency guidance of QAMS 005/80 (Staniey and Verner 1983).

Data collection and interpretation will focus on geology, geochemistry, hydrogeology, hydrochemistry, ground-water monitoring, and ground-water modeling. The characterization will be performed during and after construction of the planned ground-water monitoring network. An outline of the work to be performed is included below. Information obtained from the existing wells and wells drilled at the 216-B-63 trench will be integrated into the characterization and interpretation effort as well. The 
TABLE 3.2. EPA Interim Primary Drinking Water Standards from 40 CFR Part 265, Subpart $F(a)$

Interim Primary Drinking Water Standards

Arsenic

Barium

Cadmium

Chromium

Fluoride

Lead

Mercury

Nitrate (as N)

Selenium

Silver

Endrin

Lindane

Methoxychlor

Toxaphene

2,4-D

$2,4,5$-TP Silvex

Radium

Gross alpha

Gross beta

Coliform bacteria

Ground-Water Quality Parameters ${ }^{(c)}$

Chloride

Iron

Manganese

Phenols

Sodium

Sulfate (b)

\begin{tabular}{c} 
Maximum Level \\
\hline 50.0 \\
1000.0 \\
10.0 \\
50.0 \\
$1400-2400$ \\
50.0 \\
2.0 \\
$10,000.0$ \\
10.0 \\
50.0 \\
0.2 \\
4.0 \\
100.0 \\
5.0 \\
100.0 \\
10.0 \\
$5.0 \mathrm{pCi} / \mathrm{L}$ \\
$15.0 \mathrm{pCi} / \mathrm{L}$ \\
$4.0 \mathrm{mi} 11 \mathrm{irem} / \mathrm{yr}$ \\
$1 / 100 \mathrm{~mL}$
\end{tabular}

Ground-Water Contamination Indicator Parameters $(c)$

$\mathrm{pH}$

Specific conductance

Total organic carbon

Tota] organic halogen

(a) Regulatory requirements for sampling parameters are subject to change because of federal regulations.

(b) Unless otherwise noted, levels are in $\mu \mathrm{g} / \mathrm{L}=$ parts per billion (ppb).

(c) Maximum (or minimum $\mathrm{pH}$ ) levels not yet established. 
characterization effort is a discovery process and data collection in particular areas may expand or decrease at the discretion of Westinghouse Hanford, depending on the information obtained.

\subsubsection{Geologic Characterization}

Geologic characterization will include a lithologic description of borehole materials, a variety of physical and chemical laboratory analyses, and geophysical borehole logging (gross gamma $10 \mathrm{~g}$ ).

\subsubsection{Geologic Sampling}

Geologic samples will be collected at 5 -ft intervals and at changes in lithology. Guidance for geologic sample collection is provided by Last and Liikala (1987). Samples will be collected with a drive barrel in the unsaturated sediments whenever possible. No drilling water or other material will be added to the borehole during drive-barrel drilling unless necessary and approved by the well-site geologist, so that perched-water zones can be detected, representative moisture samples can be taken, and water chemistry will not be affected. If hard-tool drilling is necessary, a bailex will be used to collect the sediment samples. Split-barrel samples will be collected where the aquifer materials are expected to be heterogeneous (containing materials with hydraulic conductivities ranging over several orders of magnitude), or where a potential confining layer is encountered. Other split-barrel samples may be collected on an ad hoc basis. The geologic samples will be archived for possible future analyses.

Samples for moisture content determinations will be collected at $5-\mathrm{ft}$ intervals and at moist or wet zones, wherever drive-barrel techniques are used and/or the moisture contents are considered representative.

\subsubsection{Lithologic Description}

The well-site geologist will log the sedimerits and samples as they are collected at the drill site. Detailed lithologic descriptions of geologic samples will include color, texture, sorting, mineralogy, roundness, relative calcium-carbonate concentration, consolidation, and cementation. Besides a 1ithologic description, information on drill logs will document drilling and wel1-construction information plus the locations where special samples (e.g., 
moisture content) were collected. Procedures for documentation, collection, and description of geologic samples have been presented by PNL (1989).

\subsubsection{Laboratory Analysis}

Geologic samples will be analyzed in the laboratory using the following test methods:

- sieve particle size

- pipette and/or hydrometer anatyses

- permeameter testing

- calcium carbonate content

- moisture content

- bulk porosity

- petrography

- x-ray diffraction

- $x$-ray fluorescence

- atomic absorption analysis

- hazardous chemical analysis

- radionuclide analysis.

Some of these tests will be performed on every 5 - $\mathrm{ft}$ sample (e.g., sieve particle size, calcium carbonate), while other tests apply to particular types of samples. Table 3.3 summarizes the frequency, limitations, and requirements for samples to be analyzed by the various methods.

\subsubsection{Borehole Logging}

After each casing is emplaced and when the monitoring wells have been drilled to the final depth, the borehole will be geophysically logged with a gross gamma log. Procedures for geophysical well logging that are approved by Westinghouse Hanford will be used. The primary purpose of the logging will be for qualitative stratigraphic interpretation and correlation. Specifically, the gross gamma $\log$ is useful as a method of confirming the presence of fine-grained sedimentary layers, which normally produce a higher 


\section{TABLE 3.3. Laboratory Analyses to be Performed as Part of Hydrogeologic Characterization}

\begin{tabular}{|c|c|c|c|c|c|}
\hline $\begin{array}{l}\text { Laboratory } \\
\text { anayabs }\end{array}$ & $\begin{array}{l}\text { Perametor } \\
\text { monured }\end{array}$ & $\begin{array}{l}\text { Somplo } \\
\text { Requiromenist } \\
\text { Limitetioni }\end{array}$ & $\begin{array}{c}\text { Poterid } \\
\text { Ueace }\end{array}$ & $\begin{array}{c}\text { Sample } \\
\text { Frequenoy }\end{array}$ & manthos of \\
\hline Sleving & 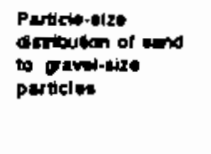 & 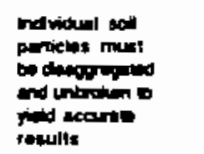 & 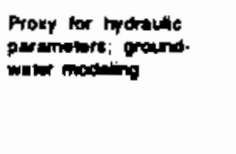 & 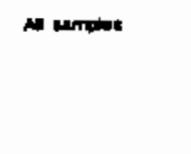 & SS, DE, HY \\
\hline Hytrominter & 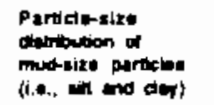 & 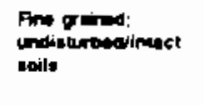 & 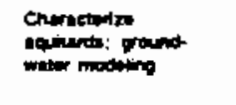 & $\begin{array}{l}\text { Ni ine-grained } \\
\text { imervels }\end{array}$ & SS. De \\
\hline Permeemoter & 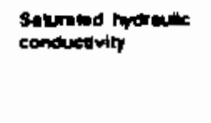 & $\begin{array}{l}\text { Intigbrososntioc1 } \\
\text { soils }\end{array}$ & 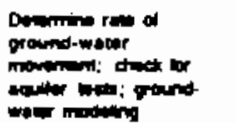 & $\begin{array}{l}\text { sintervale } \\
\text { inters }\end{array}$ & $\$$ \\
\hline Cakiem etramente & $\log _{3}$ & 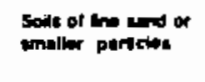 & 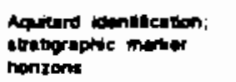 & 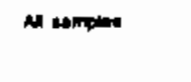 & S5. DE, HT \\
\hline Motenere conting & * wom & $\begin{array}{l}\text { Undisurowikntact } \\
\text { sodit }\end{array}$ & 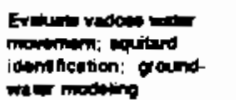 & $\begin{array}{l}\text { Nlt kino-grained } \\
\text { imaci iniervals }\end{array}$ & 55.08 \\
\hline Potrography & $\begin{array}{l}\text { Minery eproment } \\
\text { concentution }\end{array}$ & 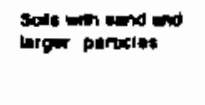 & 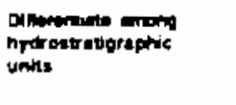 & 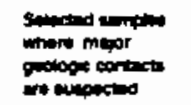 & SS, De. HT \\
\hline $\begin{array}{l}\text { X.Pay dilraenon } \\
\text { (XAD) }\end{array}$ & $\begin{array}{l}\text { Cuy menerd } \\
\text { identifiention }\end{array}$ & 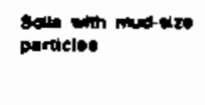 & 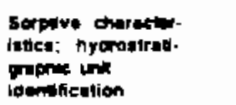 & 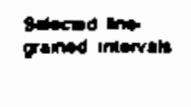 & SS. DA, HT \\
\hline $\begin{array}{l}\text { X'rnY Hornesence } \\
\text { (XAF) }\end{array}$ & 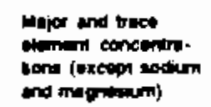 & 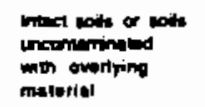 & 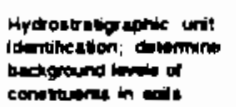 & 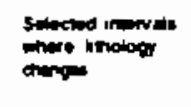 & SS. DQ, HT \\
\hline Alomenchention & 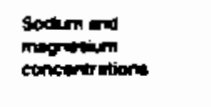 & 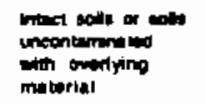 & 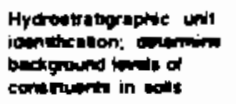 & senction & SS, DB. HT \\
\hline 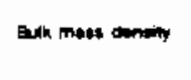 & Bull partanty & $\begin{array}{l}\text { Unditurbendintuet } \\
\text { soile }\end{array}$ & 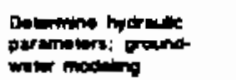 & 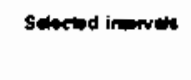 & $\mathbf{s}$ \\
\hline Herrous: & 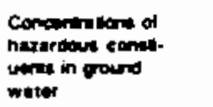 & 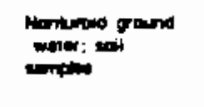 & 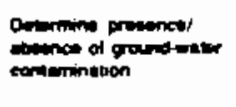 & Al prond-wation- & Pimp ton \\
\hline Fudionectiden: & 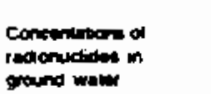 & 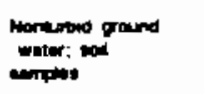 & 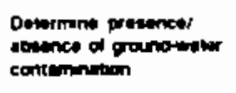 & 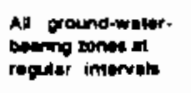 & الهـ Purn hom \\
\hline
\end{tabular}


gamna activity than coarse-grained sediments. Another potential use is to identify zones of subsurface contamination by gamma-emitting radiation. After completion, each well will be viewed with a downhole video camera to ensure that the well is clean and undamaged.

\subsubsection{Data Interpretation and Presentation}

Following an analysis and interpretation of the geologic data collected during the installation and initial monitoring of wells, an interim site characterization report will be prepared. In this report, the detailed stratigraphy in the immediate vicinity of the 216-B-63 trench will be presented in both narrative and graphic (i.e., cross sections, fence diagrams, contour maps) forms. Appendices will present the results of field and laboratory analyses, including geochemistry, lithology, moisture content, grain-size distribution, mineralogy, and petrology. An interpretation of the lithologic characteristics at each well will be presented based on sample analyses plus the visual inspection of the gross gamma log. Any gross gamma logs used previously shall be marked "uncalibrated" and the logs will be properly labeled to identify the well environment at the time of logging. Maps showing the thickness and elevation of the various stratigraphic units will be updated to reflect the new data. The geologic setting will be discussed in relation to potential contaminant flow paths. Information from the adjacent Low-Level Burial Ground waste-management area characterization activities (Last et al. 1989) will be integrated with data from this effort.

\subsubsection{Hydrogeologic Characterization}

Hydrogeologic characterization will include in situ aquifer testing to determine hydrologic properties and the determination of the rate and direction of ground-water flow in the vicinity of the 216-B-63 trench. These data will also be summarized in an interim site characterization report.

\subsubsection{Aquifer Testing}

If the amounts of contamination in the ground water are below drinking water standards, aquifer testing will be conducted in the four new wells. These tests will provide estimates of the hydrologic properties (i.e., 
transmissivity, hydraulic conductivity, storativity). of the aquifer. Aquifer tests have already been performed on two wells upgradient from the 216-B-63 trench. The results of these tests were presented in Table 2.6. This information will also be used to make estimates of the direction and magnitude of ground-water flow at each well location. The purpose of aquifer testing is to determine the large-scale hydraulic characteristics of in situ geologic materials. A carefully designed field testing program is essential to optimize the collection of hydrologic data.

Possible aquifer-test methods include bailer, step-drawdown, 8- to 24-hour constant discharge, and 8- to 24-hour recovery tests. The actual time of the constant discharge test will depend upon site-specific field conditions. A trained geologist or hydrogeologist will determine when to end each constant discharge test. Observation wells will be used wherever possible to estimate storativity and vertical anisotropy values. A pretest analysis based on an estimated range of transmissivities will be conducted to determine the type of test and the size of pump nost suitable to the given field situation. The aquifer test will not be performed until a pretest trend has been established for a period of time equal to the duration of the test. Aquifer test procedures have been presented by PNL (1989).

Proper disposal of discharge water from pumping tests can be a problem at hazardous waste sites. Ground water will be monitored and handled according to the Effluent Monitoring Plan, which will be written before water is removed from any well. If ground-water contamination is detected, aquifer testing will not continue until the water can be properly treated and disposed of.

The analytical method to be applied to the time-drawdown data will depend on the responses observed in the pumping wells and available observation wells. If both pumping and observation well data are available, hydrologic parameters will be determined by methods identified by Neuman (1974, 1975) or Weeks (1969). If observation wells show a response and the pumping well partially penetrates the aquifer, it will be necessary to evaluate the distances from the pumping well to the observation we11, the thickness of the aquifer, and the percentage of partial penetration, and consideration will be 
given to analysis methods such as those in Neuman $(1974,1975)$ or Weeks (1969). The Neuman method of analysis evaluates the delayed-yield response of an unconfined aquifer to estimate vertical anisotropy, transmissivity, and specific yield. The Weeks method of analysis evaluates transmissivity, storativity (or specific yield), and anisotropy in confined or unconfined aquifers, taking into account partial penetration effects of the pumping well and the observation well.

Pumping well data will undergo Theis and Cooper/Jacob analysis (Lohman 1979) to estimate transmissivity at the pumped we11. Extreme care must be taken in interpreting data from these wells because the saturated thickness of the aquifer is relatively thin (20-30 ft). If drawdowns exceed $10 \%$ of the saturated thickness, a correction must be made before the data can be interpreted. The equation used to correct the drawdown is reported by Fetter (1980, p. 290). Boundary analysis will also be performed if the data show positive or negative deviations from the type curves.

\subsubsection{Determination of Ground-Water Flow Paths}

Water levels will be measured in the four new monitoring wells and in several existing wells in and around the 216-B-63 trench to calculate the elevation and configuration of the water table. The direction of groundwater flow will be determined from these data. The degree of uncertainty associated with both the water-level measurements and the calculated groundwater flow directions will also be evaluated. As discussed in Section 2.3.3, the direction of ground-water flow is expected to change over the next decade, as a result of the diminishing effects of $B$ Pond on local groundwater flow.

Water levels in wells adjacent to the 216-B-63 trench will be measured at a frequency of at least every 3 months. Water levels may be measured more often if trends or ground-water fluctuations occurring at shorter intervals are suspected. They may also be measured more often if the data yield ambiguous results or the volumes of artificial recharge change significantly.

The surface of the water table and an interpretation of the direction of ground-water flow will be reported annually as required by 40 CFR Part 265, Subpart F. 


\subsubsection{Data Interpretation and Presentation}

Hydrogeologic data, interpretations, and recommendations will be presented in an interim site characterization report after well installation and initial monitoring are completed. Specifically, this report will include 1) descriptions of hydrostratigraphic units, 2) water-level data and watertable maps, 3) test data and results of analyses, 4) as-built diagrams of wells, 5) hydrochemistry data, and 6) recommendations for further characterization or construction of additional monitoring wells, if necessary.

The data will be used to evaluate whether the characterization effort and the ground-water monitoring system are adequate to define the hydrogeology in the vicinity of the trench. The hydrogeologic data will be integrated to form an initial conceptual model of the ground-water flow system(s) in the vicinity of the 216-B-63 trench. Components of the model will include the determination and description of hydrostratigraphic units, the ground-water flow paths and their possible changes over time, estimates of ground-water velocity, unsaturated zone conditions as they relate to the ground-water monitoring system, and hydrochemical characterization.

\subsection{SAMPLING AND ANALYSIS}

Ground water from the four new monitoring wells and two existing RCRA ground-water monitoring wells (299-E27-8 and 299-E34-2) will be sampled quarterly for one year and semiannually thereafter. HydroStarm(a) sampling pumps will be installed in the four new wells soon after construction is complete. The ground-water samples will be analyzed for the parameters listed in Table 3.2. Water quality samples will be analyzed by United States Testing Company (UST). After one year of quarterly monitoring, background levels for these parameters will be determined and compared with downgradient water quality results. The data will be analyzed to evaluate the groundwater quality beneath the 216-B-63 trench. After this evaluation, a decision

(a) HydroStar is a registered tradename of Instrumentation Northwest, Redmond, Washington. 
will be made either to continue quarterly monitoring of the same wells and analytical parameters, or to modify the monitoring well network and/or increase the parameters analyzed.

The samples will be analyzed according to the methods and procedures given in UST (1986). Sample analyses must meet federal (40 CFR Part 265, Subpart F) and state (Ecology 1986) requirements. Sampling, preservation, and chain-of-custody procedures are included in Appendix C.

\subsection{STATISTICAL ANALYSIS OF GROUND-WATER MONITORING DATA}

This section discusses the method of establishing background and the statistical methods that will be used to evaluate the water-chemistry data.

\subsubsection{Methods}

Quarterly samples will be collected for one year from the four new and two existing ground-water monitoring we11s (299-E34-2, 299-E27-8) for chemical analyses for the constituents listed in Table 3.2. The first set of samples will be collected after all the new wells have been completed, developed, and had sampling pumps installed. Also, once during the first year of sampling, ground-water samples will be analyzed for additional constituents listed in Appendix $C$.

After one year of quarterly monitoring, background levels for indicator parameters will be determined and compared with downgradient indicator parameters. The data will be analyzed to evaluate whether ground water is affected by the 216-B-63 trench.

\subsubsection{Estab] ishing Background}

The approach used for establishing background values for the 216-B-63 trench will be based on the results of quarterly water-level measurements of a 11 nearby we11s for one year. As of March 1988, the ground water appears to be moving west-northwest, approximately parallel to the trend of the 216-B-63 trench (see Figure 2.13). Under the present flow regime, two existing wells (299-E34-2 and 299-E27-8) can be used as background wells. Accordingly, new wells \#1, 2, and 3 would be considered downgradient wells (see Figure 3.1). 
The present ground-water flow direction, however, will probably only continue as long as the area is under the influence of the ground-water mound centered beneath $B$ Pond. The direction of ground-water flow beneath the 216-B-63 trench will 1ikely change, over time, once B Pond is decommissioned. As a result, other wells may have to be used to determine background levels in the future. Ground-water levels will be closely monitored to determine if and when it is appropriate to shift to the use of a different background we1l(s).

Recent analytical results from wells 299-E33-1 and 299-E34-2, presented in Appendix B, suggest levels in the ground water are already above the drinking water standards for nitrate. Therefore, data from upgradient wells will have to be evaluated against the results from downgradient wells to determine what the true background levels are. Establishment of background must factor out the effects of contamination from upgradient sources to prevent premature initiation of an assessment-level program.

During each quarterly sampling period, four samples will be obtained from each well for analysis of indicator parameters including total organic carbon and total organic halogen, field pH, and specific conductance (Table 3.2). In addition, background levels wil! be established for chloride, iron, manganese, phenols, and sodium.

Background summary statistics (mean, variance, and coefficient of variation) will be calculated from five quarters (16 months) of data for the indicator parameters from upgradient wells. The method used for calculating summary statistics will depend on the distribution of the data and the presence of any data that are reported as less than the limit of detection. Replicate summary statistics will be calculated each quarter. Background comparison summary statistics will be calculated from the five sets of quarterly summary statistics.

\subsubsection{Evaluation_of Data}

Wells will be sampled at least twice each year after background has been established. A minimum of four replicate measurements will be obtained from each downgradient well for the indicator parameters, and the arithmetic mean and variance will be calculated for the indicator parameters for each sample. 
The Student's t-test will be used to determine statisticaliy significant changes in the concentration of indicator-parameter constituents of downgradient wells relative to initial background concentrations or values. This comparison will consider each of the wells in the monitoring system individually. Wells downgradient of the trench will be evaluated against the upgradient well(s). For three of the indicator parameters (specific conductance, total organic carbon, and total organic halogen), a single-tailed Student's t-test will be used to test for significant increases over background at the 0.01 level of significance. The difference test for $\mathrm{pH}$ will be a two-tailed Student's t-test at the overall 0.01 level of significance.

\subsubsection{Notification and Reports}

Reports to be provided during the course of the ground-water monitoring program are summarized in Table 3.4 .

TABLE 3.4. Reports Required by 40 CFR Part 265, Subpart F, for IndicatorEvaluation Ground-Water Monitoring

Submittal

First year of sampling only: Concentrations of interim primary drinking water standards, identifying those that exceed the limits listed in Table 3.2 .

Concentrations and statistical analyses of ground-water contamination indicator parameters, noting significant differences between upgradient and downgradient wells.

Resuits of ground-water surfaceelevation evaluation, and description of response if appropriate.
Submittal Period

Within 15 days of completion of each quarterly analysis

Annually by March 1 of following year

Annually by March 1 of following year 
. 


\subsection{PHASE II. INITIATION OF GROUND-WATER QUALITY ASSESSMENT PROGRAM}

This chapter discusses the development of criteria that would dictate notification of regulatory agencies and initiation of an assessment-level monitoring program. The notifications required by 40 CFR Part 265, Subpart $F$, are presented and the assessment-level monitoring plan is outlined.

\subsection{INITIATION CRITERIA}

As indicated in Chapter 3.0, ground-water samples from all monitoring wells will be tested quarterly for interim primary drinking water standards, ground-water quality parameters, ground-water contamination indicator parameters, and site-specific parameters for the first year.

Under the indicator-evaluation monitoring program, ground-water surface elevation data will be evaluated at least annually to determine if the existing monitoring wells are appropriately located. If the evaluation indicates that existing wells are no longer adequate, the ground-water monitoring system must be modified to bring it into compliance with regulations ( 40 CFR Part 265, Subpart F).

Statistically significant changes in both the upgradient and downgradient wells must be tested for validity and documented (40 CFR Part 265, Subpart F). Statistically significant increases (or $\mathrm{pH}$ decreases) from initial background levels are those that surpass a 0.01 level of significance using the Student's t-test. If significant increases (or $\mathrm{pH}$ decreases) are noted in the downgradient wells, those wells must be immediately resampled, and the samples split in two and analyzed by independent laboratories to ensure that anomalous concentrations are not the result of laboratory error. If this second set of samples confirms significant downgradient increase for $\mathrm{pH}$ decrease), EPA and Ecology must be notified in writing within 7 days. Upon this notification, the assessment-level ground-water monitoring program outlined below shall be initiated. 


\subsection{GROUND-WATER QUALITY ASSESSMENT PROGRAM}

An assessment-level ground-water monitoring plan will be implemented if a release of hazardous constituents is detected by the indicator-evaluation monitoring system. The decision to implement the assessment-level plan will be based on the criteria just described. The assessment-1evel ground-water monitoring plan will be certified by a qualified hydrogeologist or geotechnical engineer. This plan will address the following:

- Additional ground-water monitoring wetls to be drilled, as necessary, to determine the nature and extent of contamination. The number, location, and depth of each well will be identified.

- Additional ground-water samples to be collected and analyzed at a minimum for constituents presented in Table 3.2.

- Detailed procedures to describe how analytical results will be evaluated, including the analys is of any previously gathered ground-water quality information.

- A schedule for implementation of the assessment-level ground-water monitoring plan.

A sample outline for an assessment-level ground-water monitoring plan is shown in Table 4.1. At sites where contaminants are known to have entered the ground water, regulations require that the rate and extent of contaminant movement be determined (40 CFR Part 265, Subpart F). The methods used to determine these variables will depend on the quantity and quality of the field data base. The methods will include installation of additional monitoring wells and field testing, continued chemical analyses of selected constituents in existing and new well installations, ground-water flow and contaminant transport modeling, and statistical evaluation of chemical analyses.

\subsubsection{Nature and Extent of Contamination}

Analytical data from new and existing wells will be evaluated to determine the specific hazardous and nonhazardous constituents and levels of these constituents found in the ground water. In addition, the hazardous constituents will be statistically evaluated to determine which of these constituents 
TABLE 4.1. Sample Outline for an Assessment-Level Ground-Water Monitoring $\mathrm{Pl}$ an

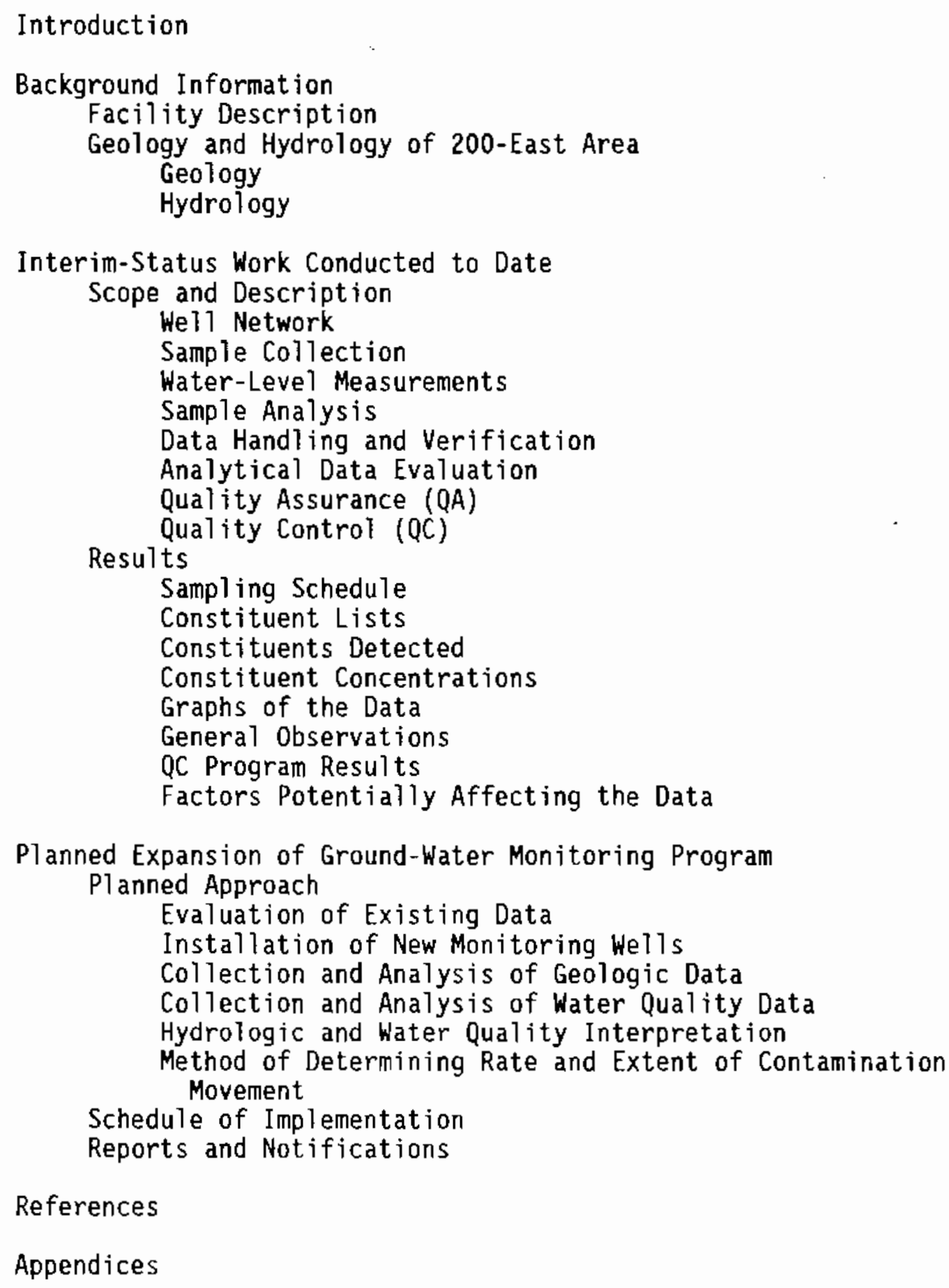


exceed background concentrations. The data will be further evaluated to determine if the source of contamination is the 216-B-63 trench or some other waste-management facility.

The lateral extent of contamination will be estimated by developing contour maps of concentrations of the various constituents. The concentrationsof hazardous constituents will be contoured to estimate the actual contamination distributions; the concentrations of nonhazardous constituents will be contoured and evaluated as indicators of ground-water and contaminant movement. The rate and extent of contamination will be conceptually evaluated based on existing data and modeling resuits.

\subsubsection{Rate of Movement}

The rate of contaminant movement will be estimated initially using values of hydraulic conductivity determined from aquifer testing, the hydraulic gradient determined from water-level measurements, and an estimated effective porosity based on the nature of the geologic material. This will provide a gross estimate for application in modeling studies and additional monitoring programs. The rate and extent of contamination will be conceptually evaluated based on existing data and modeling results. The results of the evaluation will provide insight into the areas of greatest uncertainty and thus those areas where additional data are needed. Additional wells and field testing will probably be necessary to quantify the rate and extent of contamination.

\subsubsection{Additional Well Installations}

Examination of the analytical results obtained under Phase I, coupled with preliminary flow and transport modeling, will provide the information from which the locations of additional monitoring wells will be determined. Data from these additional wells will be used to further define and quantify the rate and extent of contamination.

\subsubsection{Additional Field and Laboratory Testing}

Samples witl be collected from new and existing wells and analyzed for known hazardous waste or hazardous waste constituents and other constituents that will be useful for evaluating the rate and extent of contamination. The 
primary focus of additional field or laboratory testing will be those parameters with the highest uncertainty and that most affect flow and transport. These factors will be evaluated by preliminary modeling and sensitivity analyses. Further field and/or laboratory testing may be conducted to obtain additional information on:

- hydrostratigraphic facies distribution

- hydraulic conductivity

- porosity

- hydrautic head distribution

- retardation characteristics

- dispersivity

- other contaminant sources.

\subsubsection{Modeling}

Simple analytical models that include terms for dispersion, retardation, and radioactive decay will be used to simulate the extent and rate of contaminant plume movement, based on assumed hydraulic and retardation parameters. Numerical models that can accommodate heterogeneities in the hydrogeologic system and more complex transport conditions will also be used, if necessary, to estimate the rate and direction of flow under various hydrologic conditions. The results of modeling will be used to choose the locations of additional wells, to identify data needs and help in planning for their collection, to provide additional insight into the conceptual model of the northeastern portion of the 200-East Area, and to help in planning any corrective action, if necessary.

\subsection{CONTINUED ANALYSIS AND EVALUATION}

This section discusses the review and evaluation that will be conducted on the initiation of assessment-level monitoring. It also discusses the required notifications and reports. 


\subsubsection{Review of Methods and Procedures}

If contamination in ground-water monitoring wells is verified, the monitoring system, data evaluation methods, and sampling and analysis procedures will be reviewed. This review will evaluate whether the indicator-evaluation monitoring system is adequate to distinguish contamination derived from a source other than the 216-B-63 trench. The method of establishing background will be reviewed for its appropriateness within the hydrogeologic system. This review will consider what potential effects of other facilities may result in trends in background water quality that have not been taken into account to establish the background. Finally, the review will evaluate the current sampling and analysis procedures and whether sample bias may result from inadequacies in the procedures.

\subsubsection{Review of Sampling Parameters and Frequency}

The sampling plan will be reviewed to evaluate whether the appropriate parameters are being analyzed and whether the frequency is adequate. The assessment-level monitoring program will require additional analysis of any hazardous constituents that have been detected. During assessment-level monitoring, the sampling frequency will be increased to quarterly until it is determined that no hazardous waste from the 216-E-63 trench has entered the ground water, or until final closure of the facility, as required by 40 CFR Part 265, Subpart F.

\subsubsection{Notification and Reports}

Tabie 4.2 lists the reports and notifications that must be submitted if the facility is suspected of affecting ground water as determined by the Student's t-test. In addition to the notifications and reports provided during the indicator-evaluation program (Table 4.2, part 1), submittal of additional notification and a plan on how to assess the contamination to EPA and Ecology (Table 4.2, part 2) is also required.

Records of the ground-water quality analyses, associated ground-water surface elevations, and the various data analyses (including the statistical analyses) will be provided in these reports. 
TABLE 4.2. Reports and Notifications to be Submitted During the AssessmentLevel Monitoring Program (Phase II)

1. Required whether or not facility might be affecting ground water.

First year of sampling only: Concentrations of interim primary drinking water standards, identifying those that exceed the limits listed in Table 3.2

Concentration of and statistical analyses of ground-water contamination indicator parameters, noting significant differences between upgradient and downgradient wells

Results of ground-water surface elevation evaluation, and description of response if appropriate

2. Required if the facility might be affecting ground water.

Notification to EPA and Ecology that the facility might affect ground water

Submittal of ground-water assessment plan to EPA and Ecology

Submittal to EPA and Ecology of a written report on assessment of ground-water quality, including concentrations of hazardous waste constituents and their rate and extent of migration

Results of the ground-water quality assessment program

Within 15 days of completion of each quarterly analysis

Annually by March 1 of following year

Annually by March 1 of following year

Within 7 days of confirmation of a significant increase in any parameter (or a decrease in $\mathrm{pH}$ )

Within 15 days of the above notification

Within 15 days of first determination of a significant increase in any parameter (or a decrease in $\mathrm{pH}$ ) as soon as technically feasible

Annually, by March 1 of following year, until closure of facility 
$\checkmark$ 


\subsection{REFERENCES}

40 CFR Part 265, Subpart F. "Interim Status Standards for Owners and Operators of Hazardous Waste Treatment, Storage, and Disposal Facilities." U.S. Government Printing Office, Washington, D.C.

Bjornstad, B. N. 1984. Suprabasalt Stratigraphy Within and Adjacent to the Reference Repository Location. SD-BWI-DP-039, Rockwell Hanford Operations, Richland, Washington.

Bjornstad, B. N. 1985. "Late-Cenozoic Stratigraphy and Tectonic Evolution Within a Subsiding Basin, South-Central Washington." Geologic Society of America, Abstracts with Programs 17(7):524.

Bjornstad, B. N., K. R. Fecht, and A. M. Tal1man. 1987. Quaternary

Stratigraphy of the Pasco Basin Area, South-Central Washington. RHO-BW-SA563A, Rockwell Hanford Operations, Richland, Washington.

Boulton, N. S. 1963. "Analys is of Data from Non-Equilibrium Pumping Tests Allowing for Delayed Yield from Storage." Inst. Civil Engrs. Proc. 26:469482 .

Bretz, J. H., H. T. U. Smith, and G. E. Neff. 1956. "Channeled Scabland of Washington: New Data and Interpretations." Geological Society of America Bulletin 67:957-1049.

Caggiano, J. A., and D. W. Duncan (eds). 1983. Preliminary Interpretation of the Tectonic Stability of the Reference Repository Location, Cold Creek Syncline, Hanford Site. RHO-BW-ST-19P, Rockwell Hanford Operations, Richland, Washington.

Coony, F. M., D. B. Howe, and L. J. Voigt. 1988. Westinghouse Hanford Company Effluent Releases and Sol id Waste Management Report for 1987: 200/600/1100 Areas. WHC-EP-0141, Westinghouse Hanford Company, Richland, Washington.

Cooper, H. H., and C. E. Jacob. 1946. "A Generalized Graphical Method for Evaluating Formation Constants and Summarizing Well-Field History." Irans., American Geophysical Union 27:526-534.

DOE (U.S. Department of Energy). 1987. 216-B-63 Trench Preliminary Closure/Post-Closure P]an, Rev. 0, U.S. Department of Energy, Richland Operations, Richland, Washington.

DOE. 1988. Consultation Draft, Site Characterization Plan. Volumes 1 and 2, DOE/RW-0164, U.S. Department of Energy, Richland, Washington.

EPA (U.S. Environmental Protection Agency). 1986. RCRA Groundwater Monitoring Technical Enforcement Guidance Document (TEGD). OSWER-9950.1. U.S. Government Printing Office, Washington, D.C. 
Ecology (Washington State Department of Ecology). 1986. Dangerous Waste Regulations. Washington Administrative Code, Chapter 173-303, 01ympia, Washington (amended July 1986).

Fecht, K. R., S. P. Reidel, and A. M. Tallman. 1985. Paleodrainage of the Columbia River System on the Columbia Plateau of Washington State: A Summary. RH0-BW-SA-318P, Rockwell Hanford Operations, Richland, Washington.

Fetter, C. W., Jr. 1980. Applied Hydrogeology. Charles E. Merrill, Columbus, Ohjo.

Gee, G. W. 1987. Recharge at the Hanford Site: Status Report. PNL-6403, Pacific Northwest Laboratory, Richland, Washington.

Gephart, R. E., R. C. Arnett, R. G. Baca, L. S. Leonhart, and F. A. Spane. 1979. Hydraulic Studies Within the Columbia Plateau, Washington: An Integration of Current Knowledge. RHO-BWl-ST-5, Rockwell Hanford Operations, Richland, Washington.

Graham, M. J., M. D. Ha71, S. R. Strajt, and W. R. Brown. 1981. Hydrology of the Separations Area. RHO-ST-42, Rockwell Hanford Operations, Richland, Washington.

Graham, M. J., G. V. Last, and K. R. Fecht, 1984. An Assessment of Aquifer Intercommunication in the B Pond-Gable Mountain Pond Area of the Hanford Site. RHO-RE-ST-12P, Rockwell Hanford Operations, Richland, Washington.

Jensen, E. J. 1987. An Evaluation of Aquifer Intercommunication Between the Unconfined and Rattlesnake Ridge Aquifers on the Hanford Site. PNL-6313, Pacific Northwest Laboratory, Richland, Washington.

Jungfleish, F. 1988. Preliminary Evaluation of Hanford Liquid Discharges to Ground. WHC-EP-0052, Westinghouse Hanford Company, Richland, Washington.

Last, G. V., and T. L. Liikala. 1987. A Field Guide for Well-Site

Geologists: Cable-Tool Drilling. PNL-6392, Pacific Northwest Laboratory, Richland, Washington.

Last, G. V., B. N. Bjornstad, M. P. Bergeron, M. A. Chamness, C. S. Cline, S. P. Airhart, and J. S. Wilbur. 1989. Interim Characterization Report for the 200 Area Low-Level Burial Ground Detection-Level Monitoring Project.

PNL-6820, Pacific Northwest Laboratory, Richland, Washington.

Law, A. G., J. A. Serkowski, and A. L. Schatz. 1987. Results of the Separations Area Ground-Water Monitoring Network for 1986. RHO-RE-SR-87-24P, Rockwell Hanford Operations, Richland, Washington.

Lohman, S. W. 1979. Ground-Water Hydraulics. Professional Paper 708, U.S. Geological Survey, U.S. Government Printing Office, Washington, D.C. 
Maxfield, H. L. 1979. 200 Areas Waste Sites. RHO-CD-673, Volume I, Rockwell Hanford Operations, Richland, Washington.

Mullineaux, D. R., R. E. WiTcox, W. F. Ebaugh, R. Fryxe11, and M. Rubin. 1978. "Age of the Last Major Scabland Flood of the Columbia Plateau in Eastern Washington." Quaternary Research 10:171-180.

Myers, C. W., S. M. Price, J. A. Caggiano, M. P. Cochran, H. H. Czimer, N. J. Davidson, R. C. Edwards, K. R. Fecht, G. E. Holmes, M. G. Jones, T. H. Mitchel1, E. H. Price, S. P. Reide], and A. M. Tallman, 1979. Geologic Studies of the Columbia Plateau: A Status Report. RHO-BWI-ST-4, Rockwell Hanford Operations, Richland, Washington.

Myers, C. W., and S. M. Price, eds. 1981. Subsurface Geology of the Cold Creek Syncline. RHO-BWI-ST-14, Rockwell Hanford Operations, Richland, Washington.

Neuman, S. P. 1974. "Effect of Partial Penetration on Flow in Unconfined Aquifers Considering Delayed Gravity Response." Hater Resources Research $10: 303-312$.

Neuman, S. P. 1975. "Analysis of Pumping Test Data from Anisotropic Unconfined Aquifers Considering Delayed Gravity Response." Water Resources Research $11: 325-342$.

PNL (Pacific Northwest Laboratory). 1987. Out] ine for a Ground-Water Monitoring Compliance Plan for the 216-B-63 Trench, Hanford Site, Washington. Prepared for the U.S. Department of Energy by Pacific Northwest Laboratory, Richland, Washington.

PNL (Pacific Northwest Laboratory). 1989. Procedures for Ground-Water Investigations. PNL-6894, Pacific Northwest Laboratory, Richland, Washington.

Reidel, S. P., K. R. Fecht, and R. W. Cross. 1982. "Constraints on Tectonic Models for the Columbia Plateau from the Age and Growth Rates of Yakima Folds." Proceedings, 33rd Alaska Science Conference, Vol. 12, Arctic Division, American Association for Advancement of Science.

Schatz, A. L., J. J. Ammerman, and J. A. Serkowski. 1987. Hanford Site Water-Table Map, June 1987. WHC-EP-0054, Westinghouse Hanford Company, Rich1and, Washington.

Schatz, A. L., and J. J. Ammerman. 1988. Ground-Water Maps of the Hanford Site Separations Area, December, 1987. WHC-EP-0142, Westinghouse Hanford Company, Richland, Washington.

Serkowski, J. A., A. G. Law, J. L. Ammerman, and A. L. Schatz. 1988. Results of Ground-Water Monitoring for Radionuclides in the Separations Area, 1987. WHC-EP-0152, Westinghouse Hanford Company, Richland, Washington. 
Stanley, T. W., and S. S. Verner. 1983. Interim Guidelines and Specifications for Preparing Quality Assurance Project P7ans. EPA-600/4-83-004, U.S. Environmental Protection Agency, Washington, D.C.

Stone, W. A., J. M. Thorp, 0. P. Gifford, and D. J. Hoit ink. 1983. Climatological Summary for the Hanford Area. PNL-4622, Pacific Northwest Laboratory, Richland, Washington.

Swanson, D. A., T. L. Wright, R. P. Hooper, and R. D. Bentley. 1979. Revisions in Stratigraphic Nomenclature of the Columbia River Basalt Group. Bulletin 1457-G, U.S. Geological Survey, U.S. Government Printing office, Washington, D.C.

Tallman, A. M., K. R. Fecht, M. C. Marratt, and G. V. Last. 1979. Geology of the Separation Areas, Hanford Site, South-Central Washington. RH0-ST-23, Rockwell Hanford 0perations, Richland, Washington.

Theis, C. V., R. H. Brown, and R. R. Meyer. 1963. "Estimating the Transmissibility of Aquifers from the Specific Capacity of Wells." In Methods of Determining Permeability. Transmissibility and Drawdown, R. Bentall, ed. U.S. Geological Survey Water-Supply Paper 1536-I, U.S. Government Printing office, Washington, D.C.

Tolan, T. L. 1986. Tectonic Map of the Columbia Plateau and Adjacent Areas Scale 1:50,000. SD-BWI-TI-320, Rockwell Hanford Operations, Richland, Washington.

United States Testing (UST). 1986. Procedures Manual. UST-RD-PM-9-80, Rev. 3, United States Testing Company, Inc., Richland, Washington.

Wallace, R. W. 1977. A Comparison of Evapotranspiration Estimates Using ERDA Hanford Climatological Data. PNL-2698, Pacific Northwest Laboratory, Richland, Washington.

Weeks, E. P. 1969. "Determining the Ratio of Horizontal to Vertical Permeability by Aquifer-Test Analysis." Water Resources Research 5:196-214. 


\section{APPENDIX A}

GEOLOGIC AND WELL CONSTRUCTION DIAGRAMS FOR EXISTING WELLS 


\section{APPENDIX A}

\section{GEOLOGIC AND WELL CONSTRUCTION DIAGRAMS FOR EXISTING WELLS}

Drilling logs from the three existing wells within $1000 \mathrm{ft}$ of the 216-B-63 trench are included here for reference. The following well logs were reviewed and are included in this appendix:

$\begin{array}{ccc}\text { Wel1 } & \begin{array}{c}\text { Date } \\ \text { Completed }\end{array} & \begin{array}{c}\text { Location } \\ \text { (by Hanford Plant } \\ \text { Coordinates) }\end{array} \\ 299-E 27-8 & 9 / 87 & N 44496 / W 49742 \\ 299-E 34-1 & 6 / 61 & N 45129 / W 50023 \\ 299-E 34-2 & 9 / 87 & N 45076 / W 50048\end{array}$

Two of the existing wells are recent wells drilled by PNL to monitor the LowLevel Burial Ground waste-management area northeast of the 216-B-63 trench (Last et al. 1989). The drilling and well-construction information presented in this appendix, including well completion reports, as-built diagrams, and geologic and geophysical logs, is from Last et a1. (1989). Information presented on well 299-E34-1 is limited to a single diagram. 


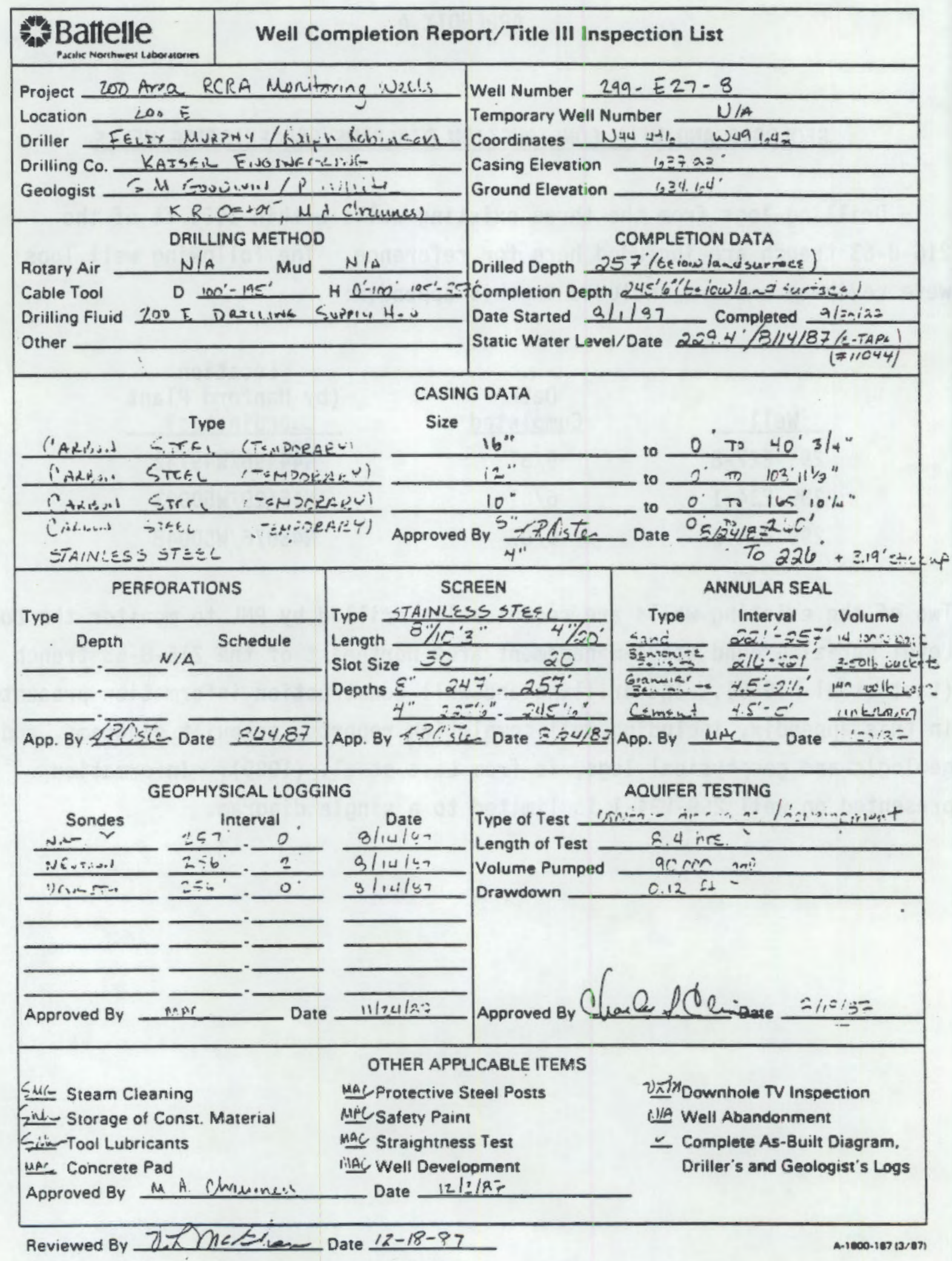

FIGURE A.1. Well Completion Report for Well 299-E27-8 


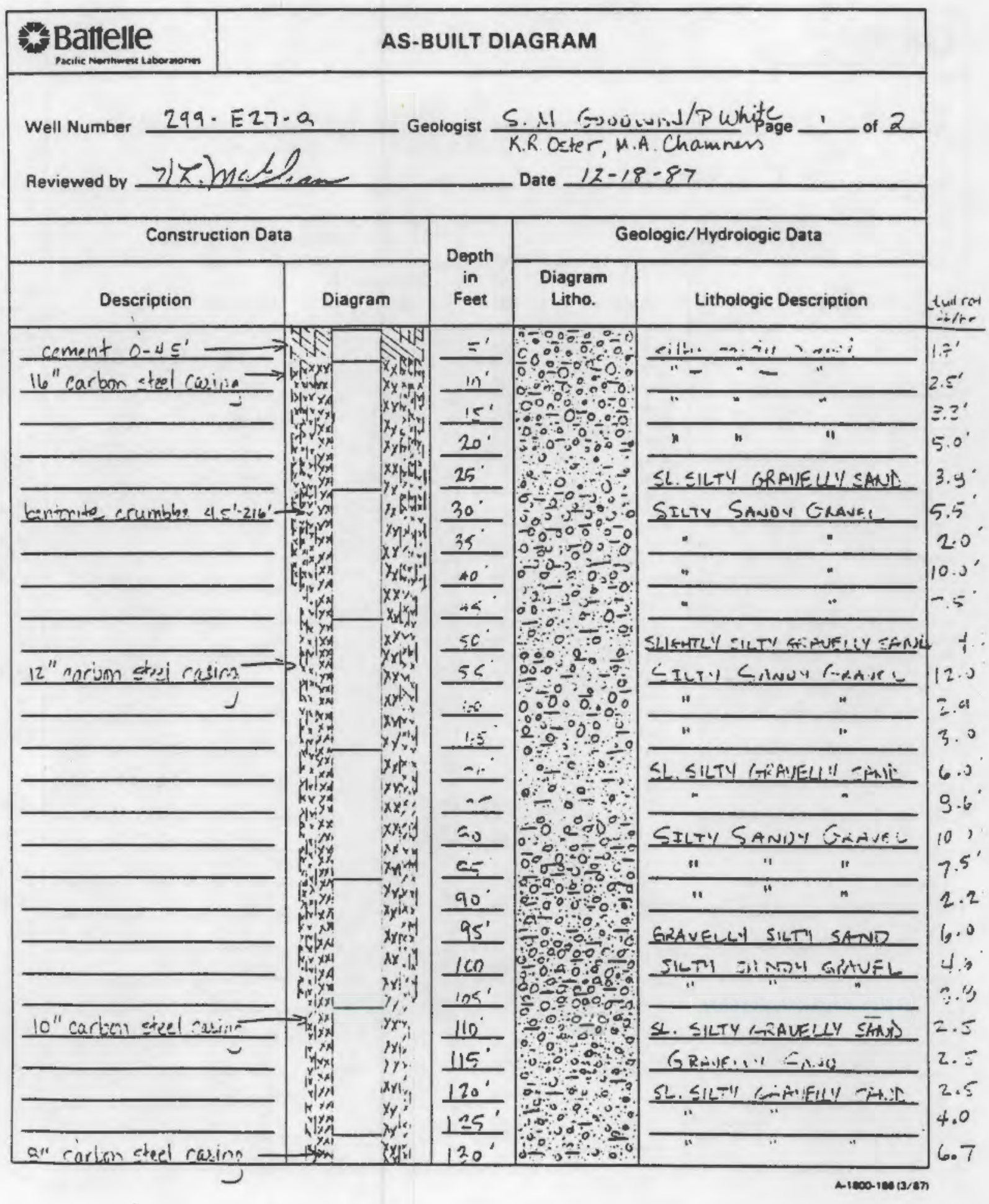

FIGURE A.2 As-Built Diagram for Well 299-E27-8 (page 1 of 2) 


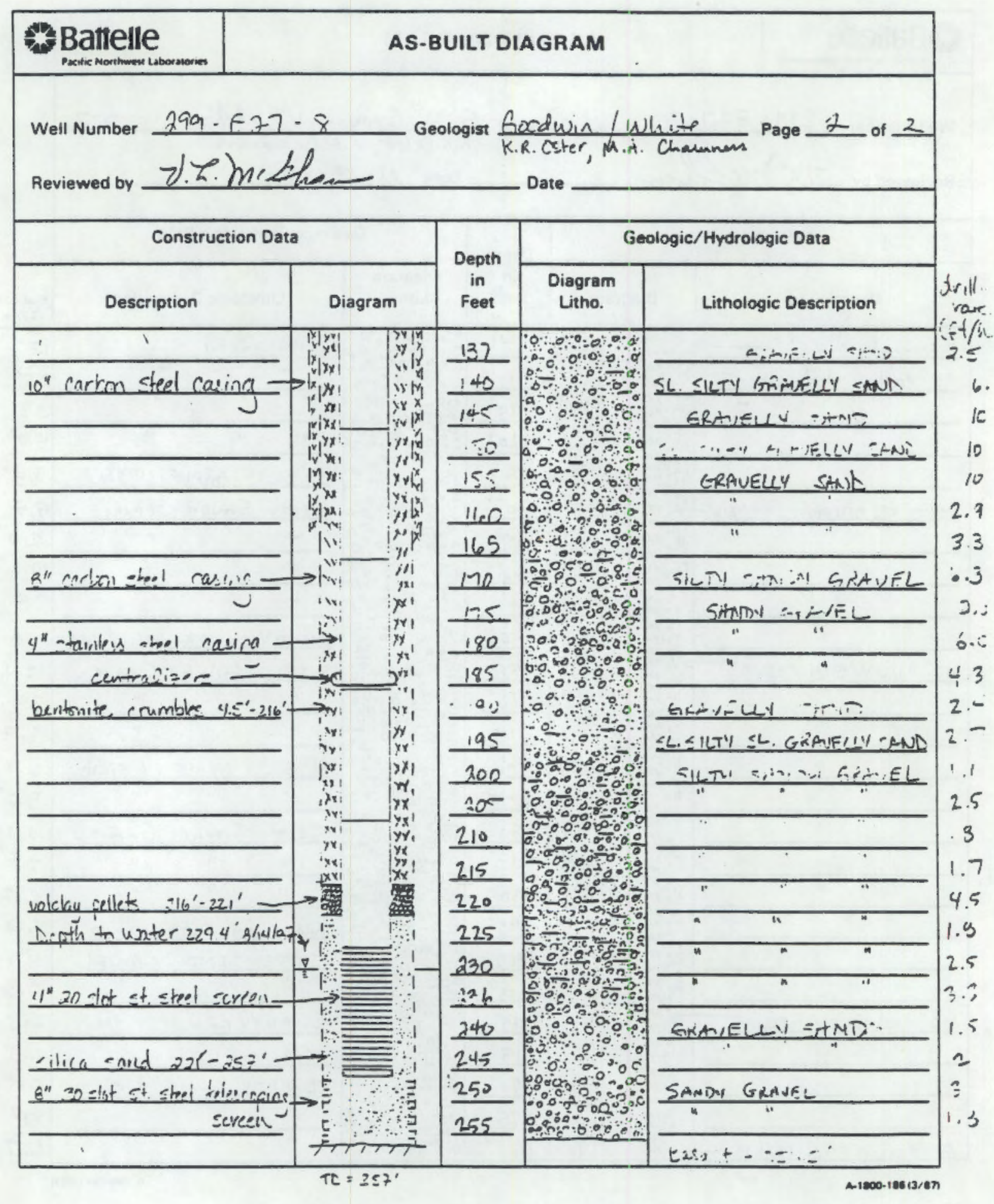

FIGURE A.2. (contd) (page 2 of 2) 


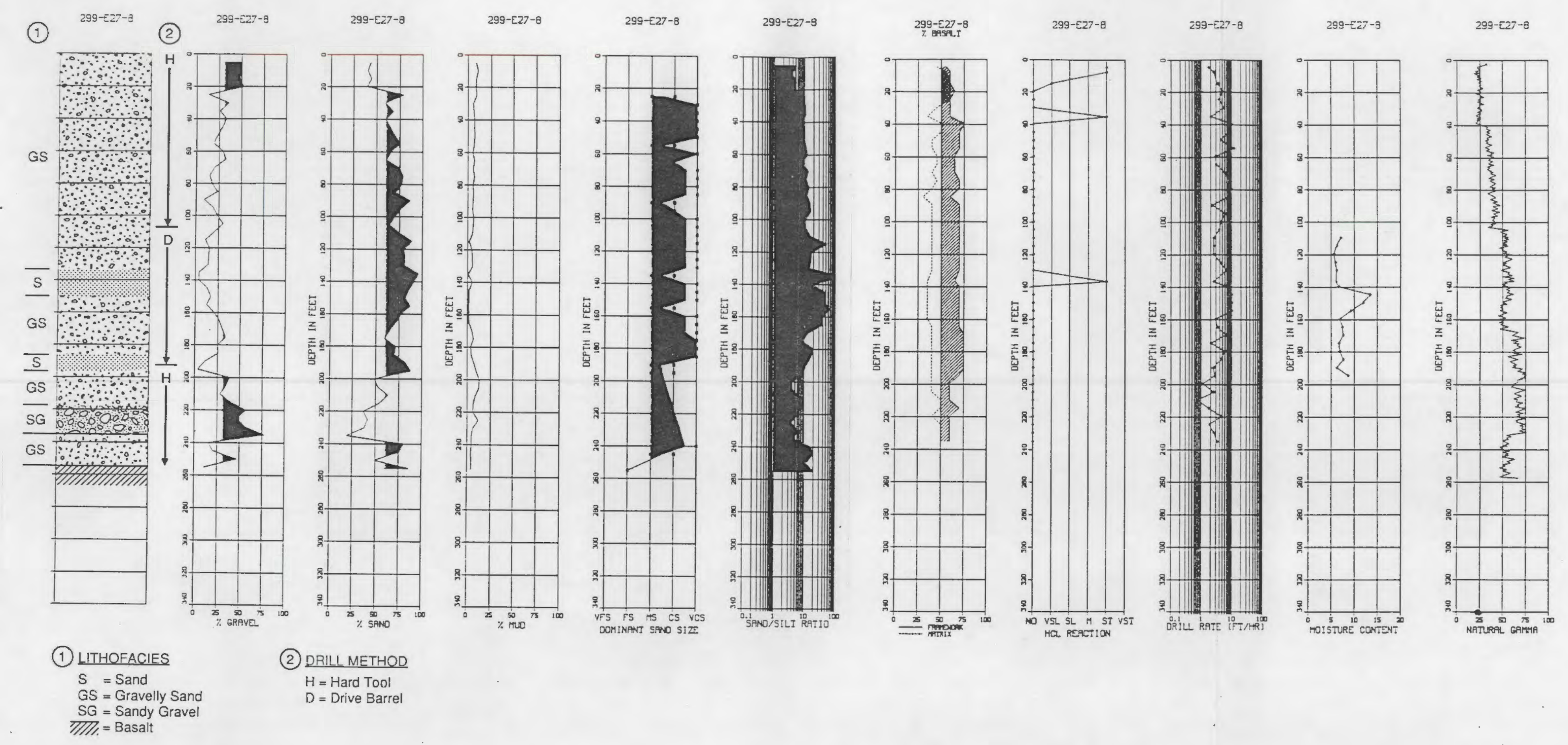

FIGURE A.3. Geologic and Geophysical Data for Well 299-E27-8 


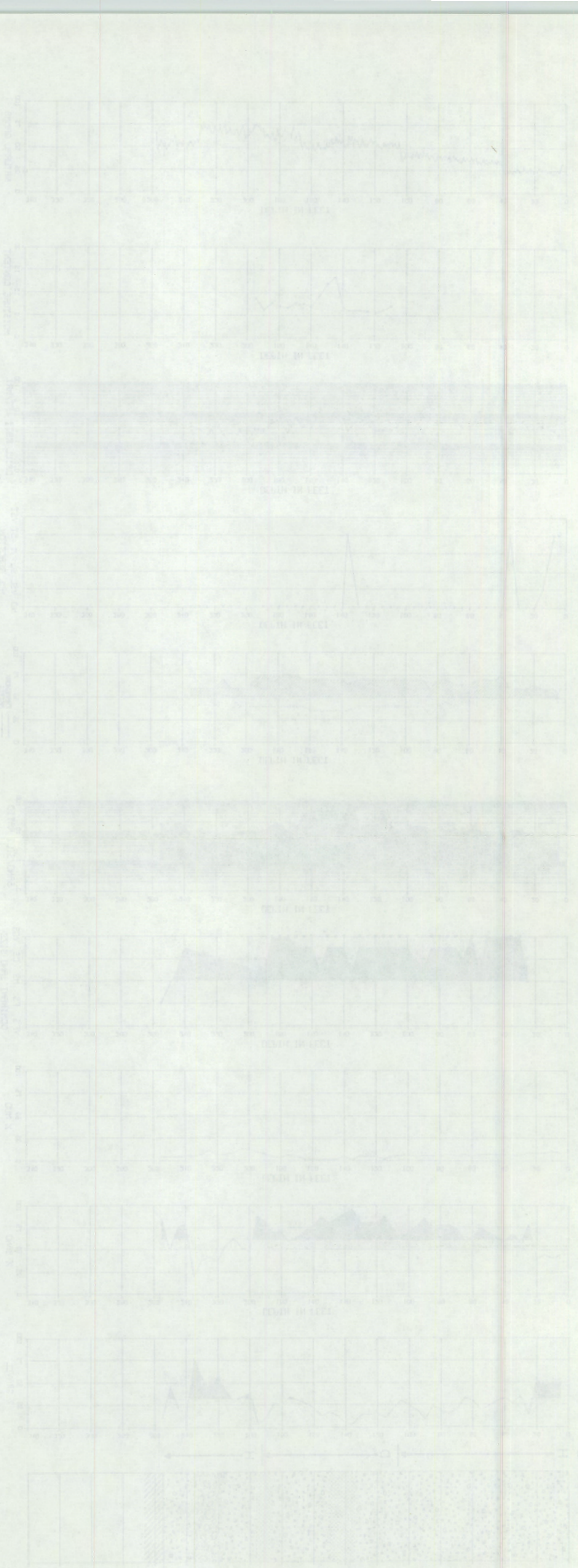


299-E34-1

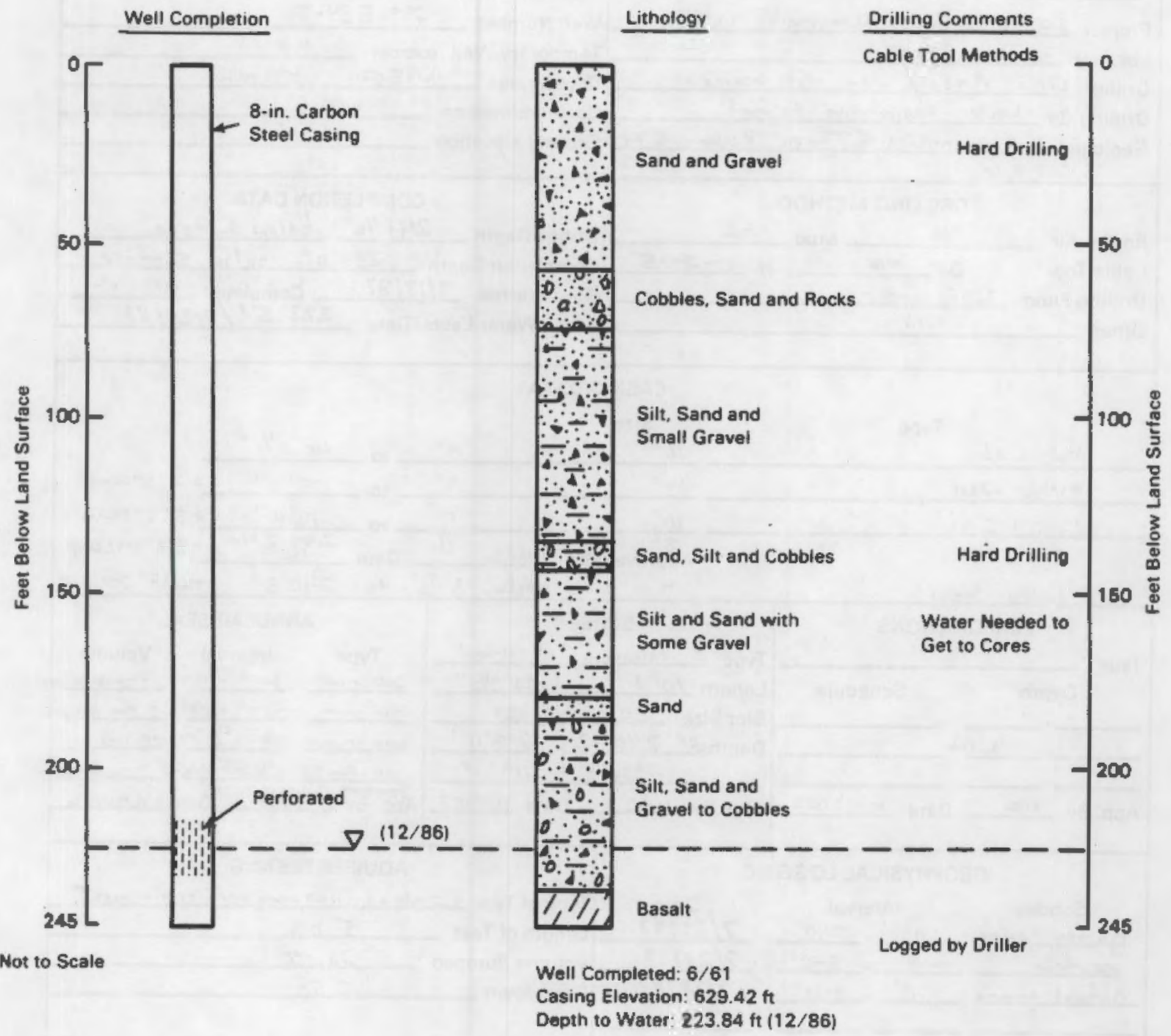

FIGURE A.4. Summary Lithologic and Well-Construction Log for Well 299-E34-1 


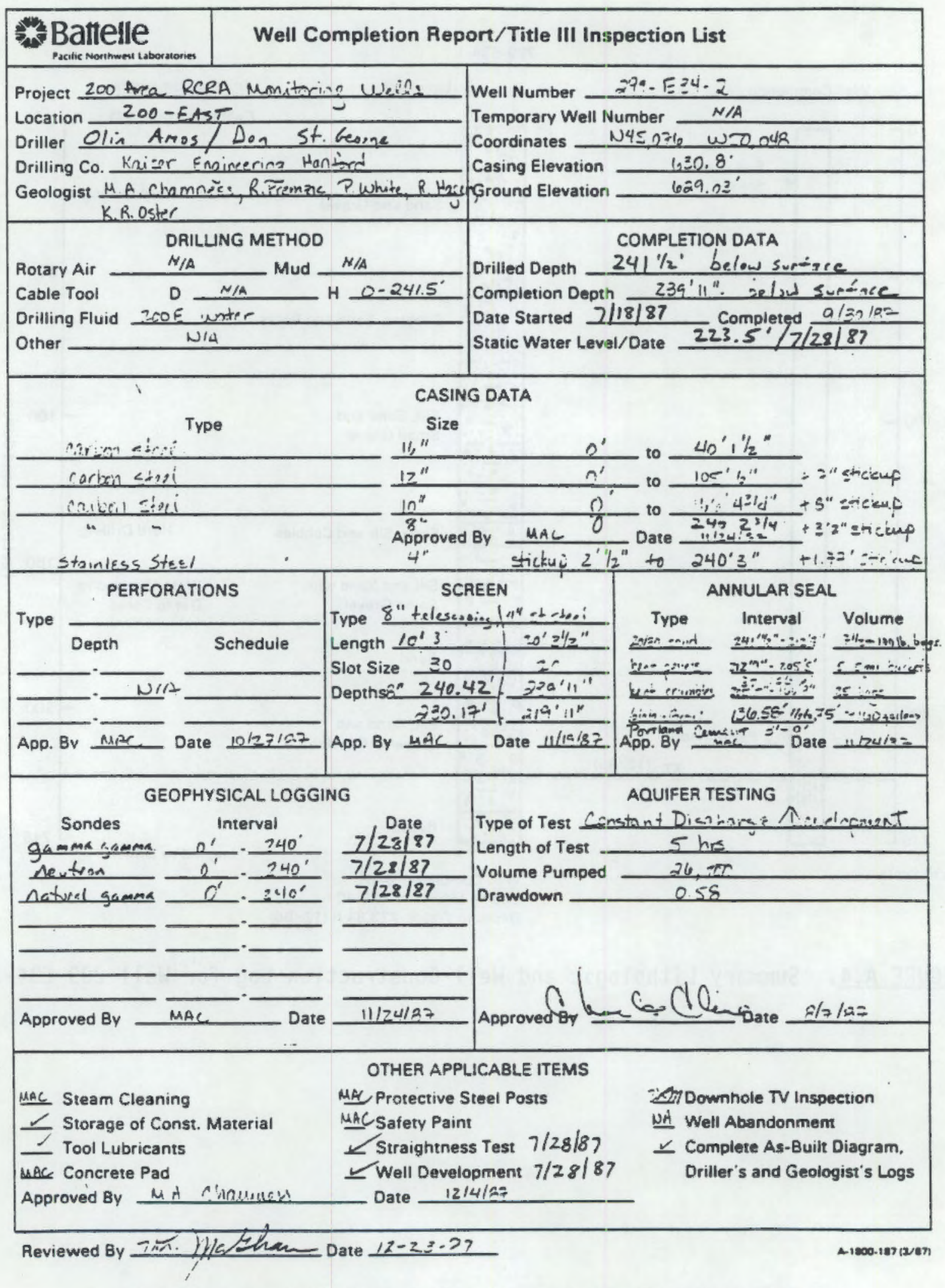

\section{FIGURE A.5. Well Completion Report for Well 299-E34-2}




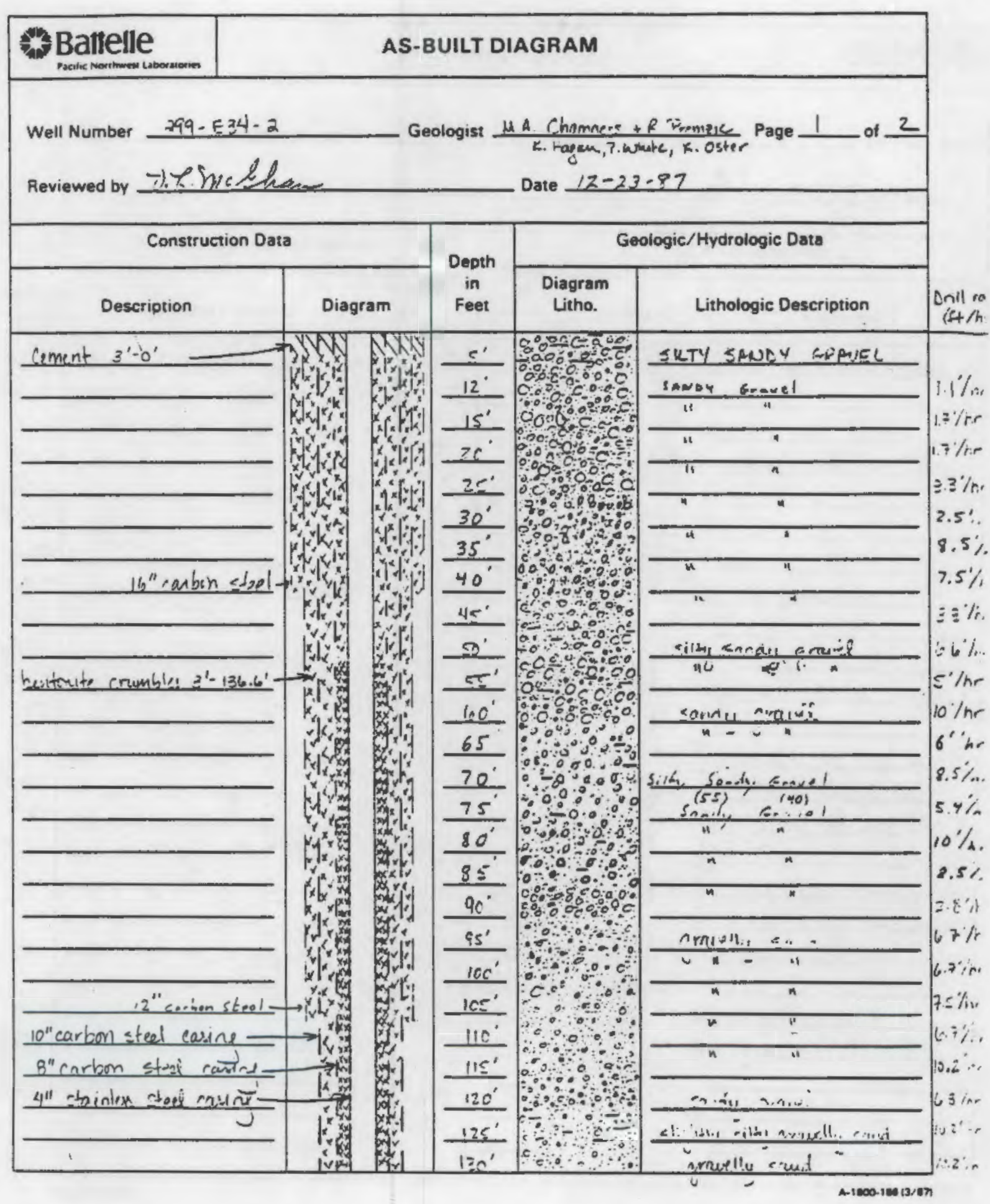

FIGURE A.6. As-Built Diagram for Well 299-E34-2 (page 1 of 2) 


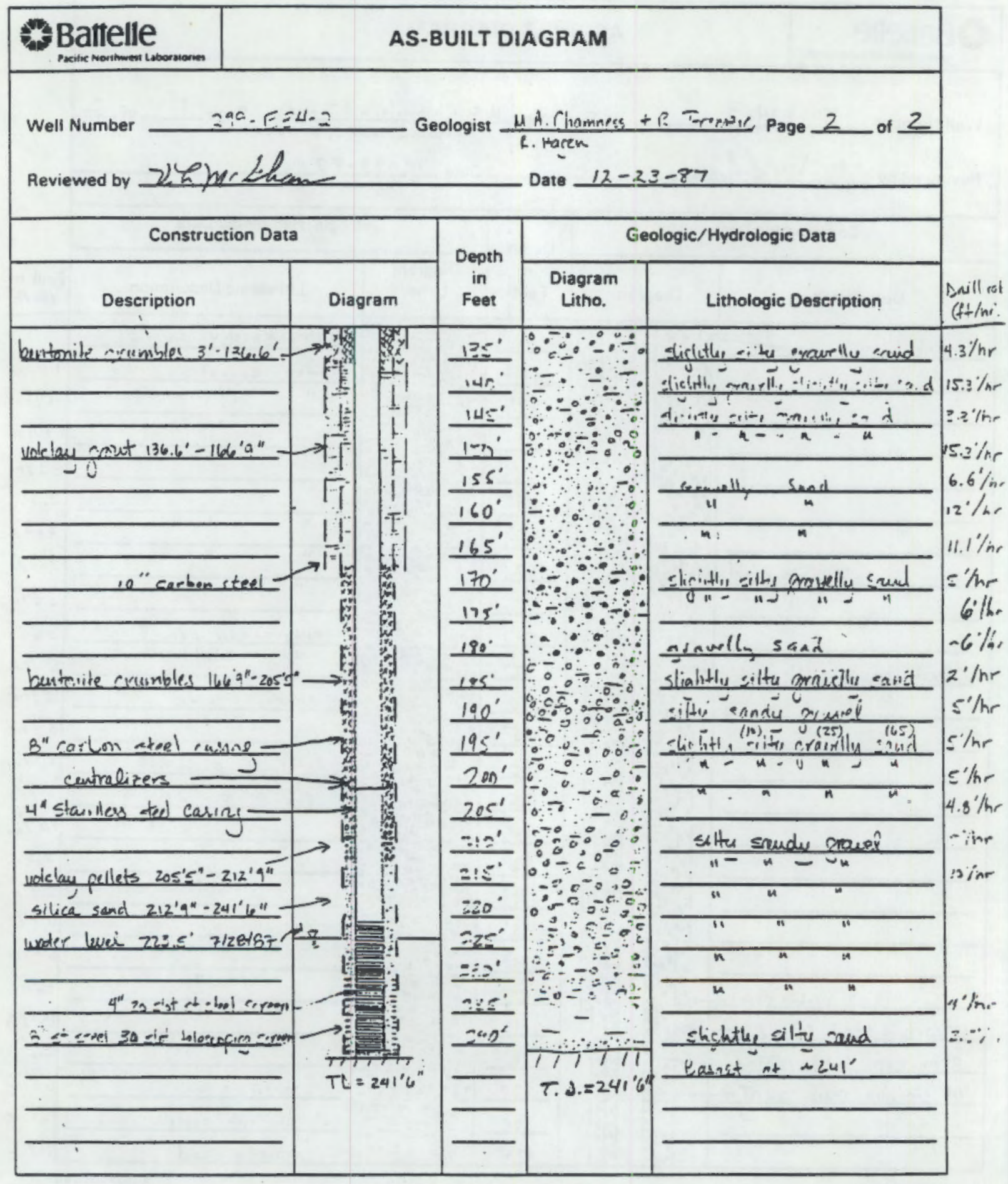

A.1600-18s 13/8n

FIGURE A.6. (contd) (page 2 of 2) 

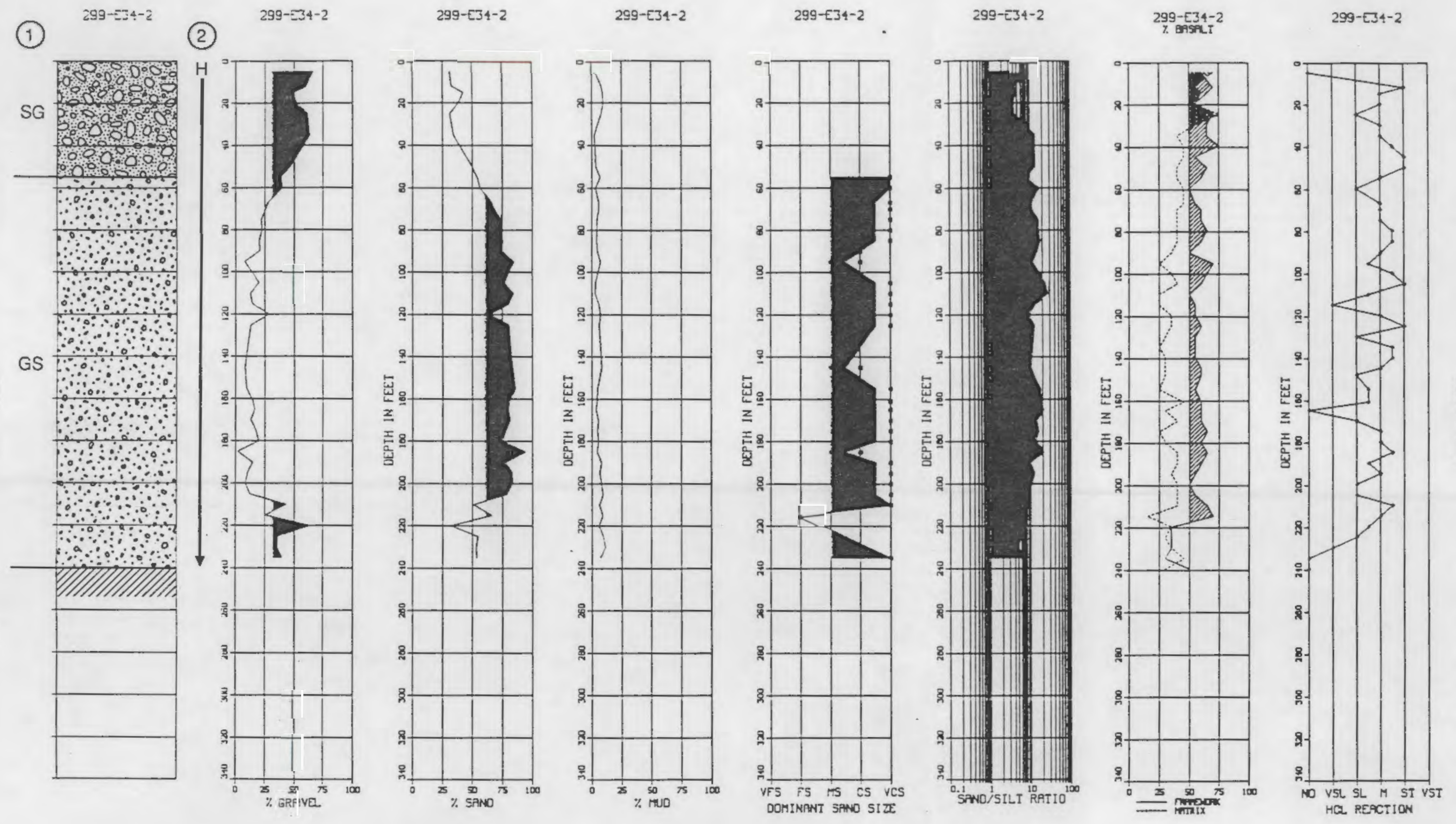

$299-534-2$

$299-234-2$

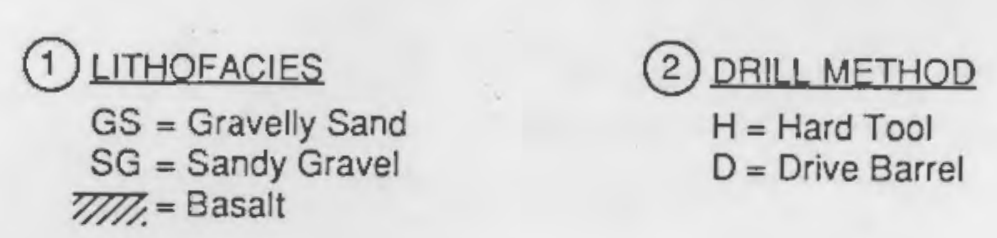

FIGURE A.7. Geologic and Geophysical Data for Well 299-E34-2 


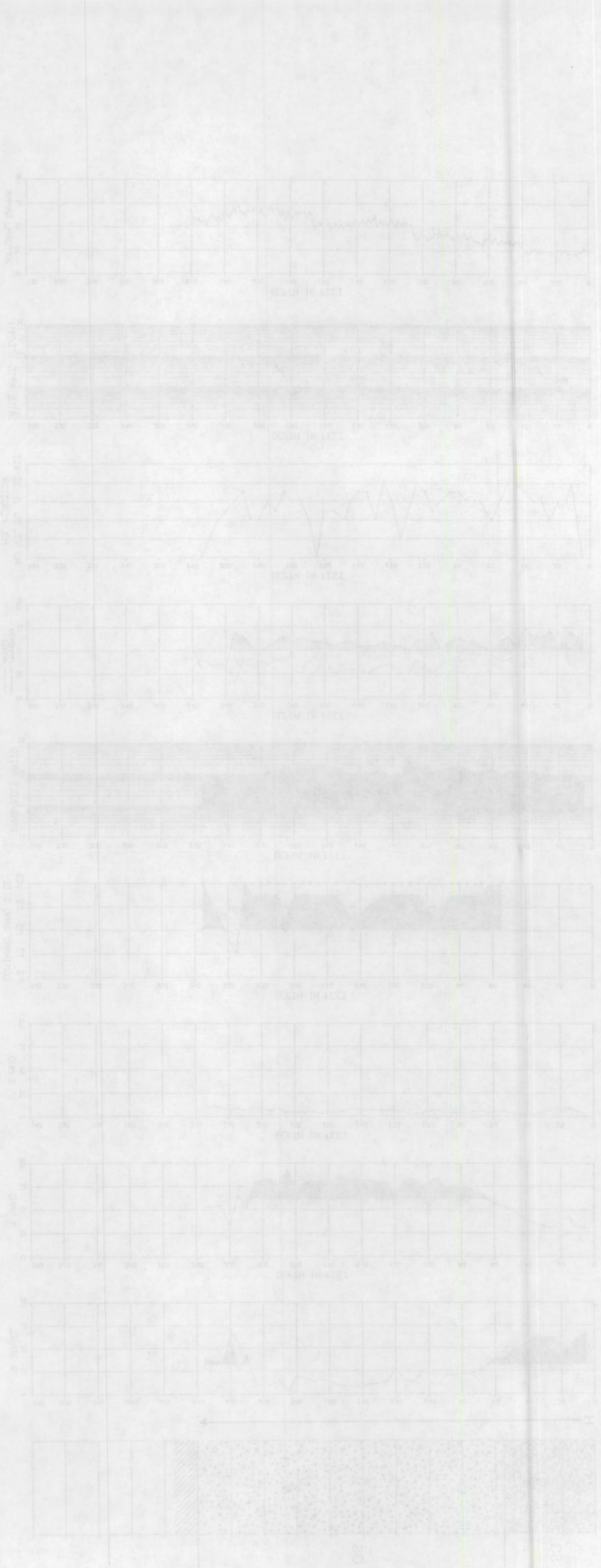




\section{REFERENCES}

Last, G. V., B. N. Bjornstad, M. P. Bergeron, M. A. Chamness, A. S. Cline, S. P. Airhart, and J. S. Wilbur. 19B9. Interim Characterization Report for the 200 Area Low-Level Burial Ground Detection-Level Monitoring Project.

PNL-6820, Pacific Northwest Laboratory, Richland, Washington. 
$\checkmark$ 


\section{APPENDIX B}

WATER-CHEMISTRY DATA LISTINGS AND SUMMARIES 
APPENDIX B

\section{WATER-CHEMISTRY DATA LISTINGS AND SUMMARIES}

This appendix presents recent chemical data available from all existing wells within $1000 \mathrm{ft}$ of the 216-B-63 trench. These include:

- 299-E27-8

- 299-E34-1

- 299-E34-2.

However, because these welis are all currently upgradient (east) of the trench, data from one downgradient weil (299-E33-18) are included for completeness, even though it is more than $1000 \mathrm{ft}$ from the trench and may not be representative of ground-water quality immediately downgradient of the trench.

Ground-water samples from the 200-East Area wells have been analyzed for the various constituents 7 isted in Table B.1, although not all samples have been anaiyzed for all constituents. The most recent concentrations of constituents present in samples from the four wells are listed in Tabie B.2. The "less-than" flag indicates that samples were below the detection limit for that constituent. Negative analysis values, associated with certain radiological constituents, indicate samples were below background radiation leve?s. 
IABLE B.1. List of Possible Constituents Analyzed for in Separations Areas Ground-Water Samples

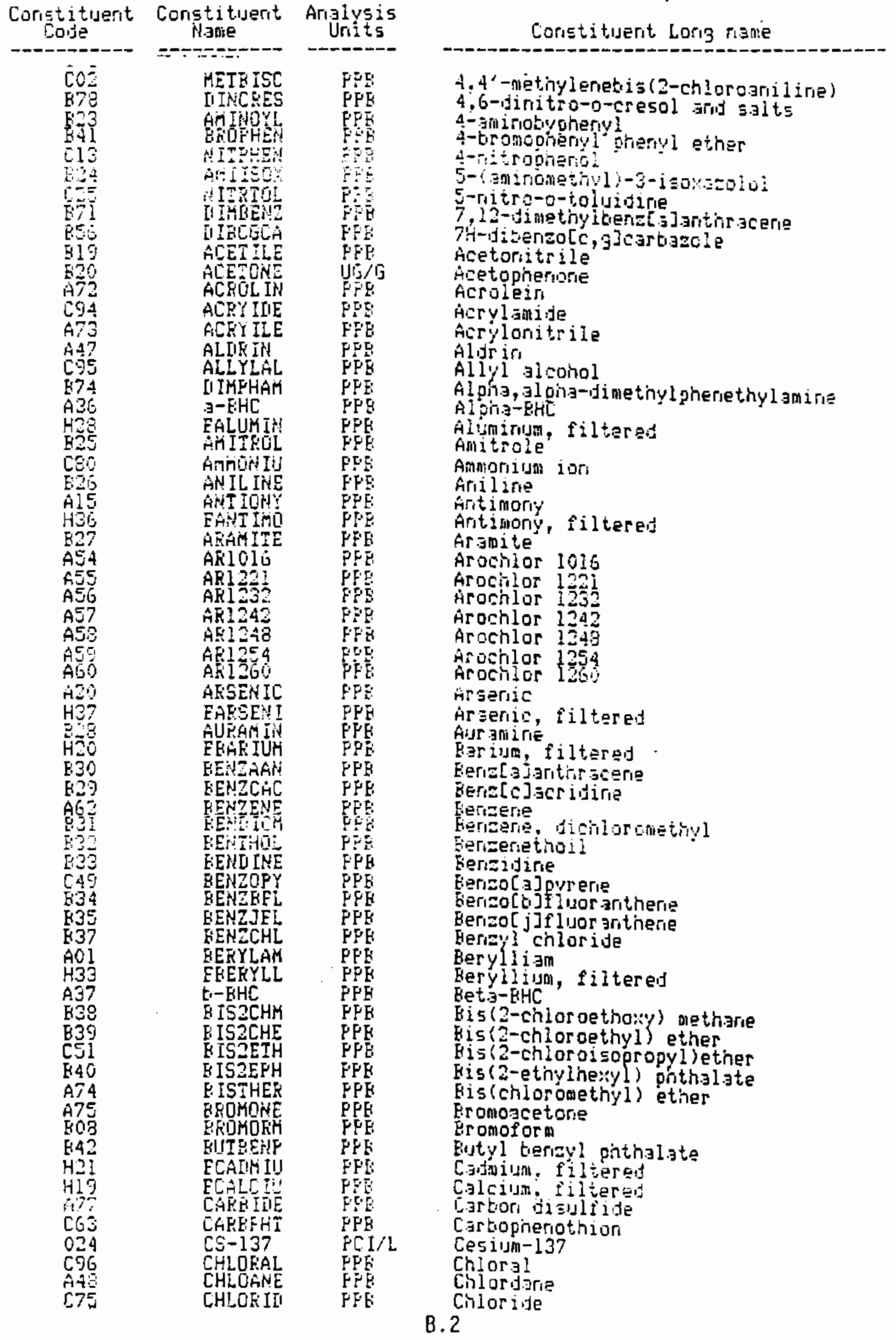


TABLE B.1. (contd)

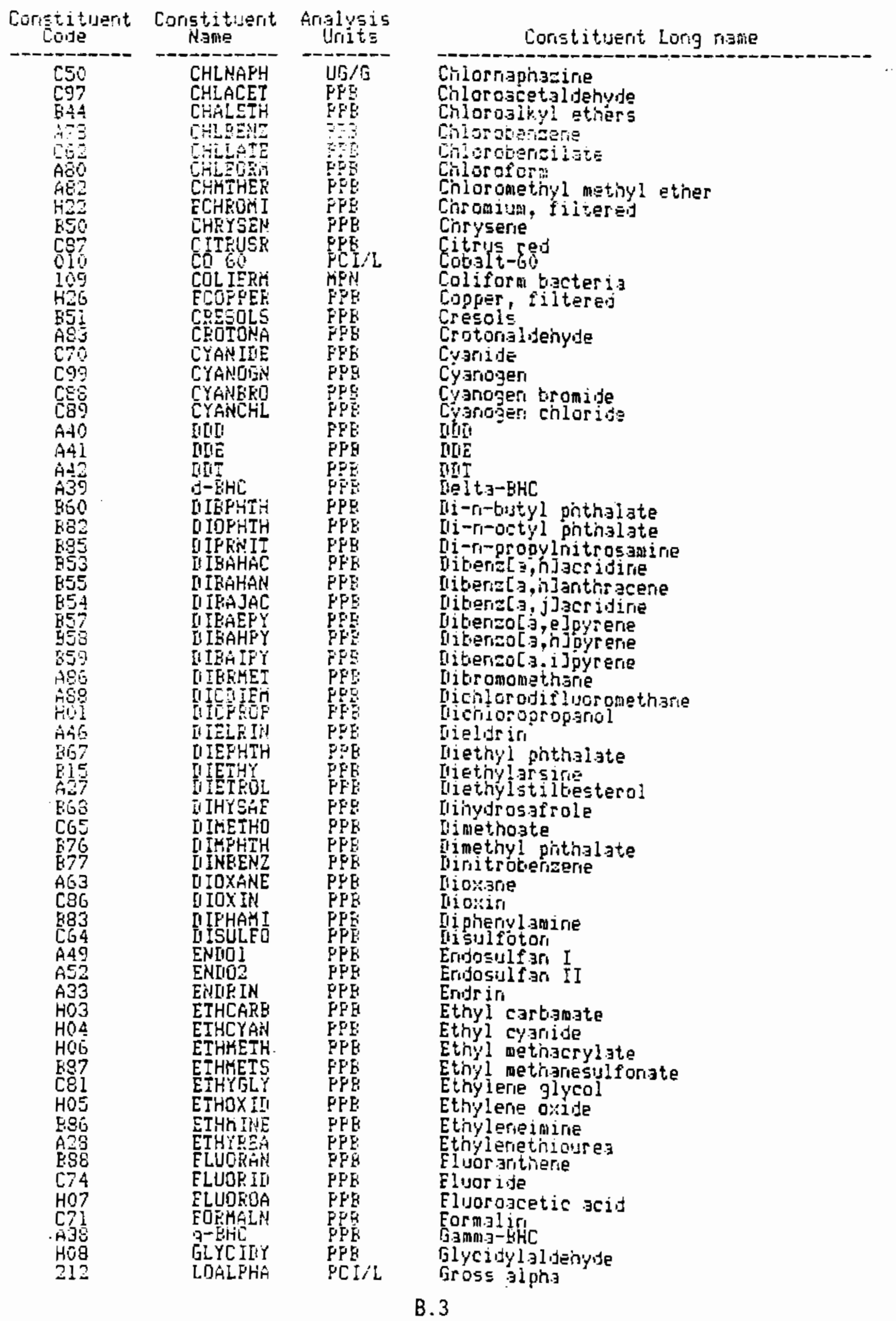




\section{IABLE B.1. (contd)}

\begin{tabular}{|c|c|c|c|}
\hline $\begin{array}{c}\text { Corigtitiserit } \\
\text { Code }\end{array}$ & $\begin{array}{c}\text { Congtit.userit } \\
\text { Name }\end{array}$ & $\begin{array}{c}\text { Arialusis } \\
\text { Urites }\end{array}$ & Constituent Lorg name \\
\hline 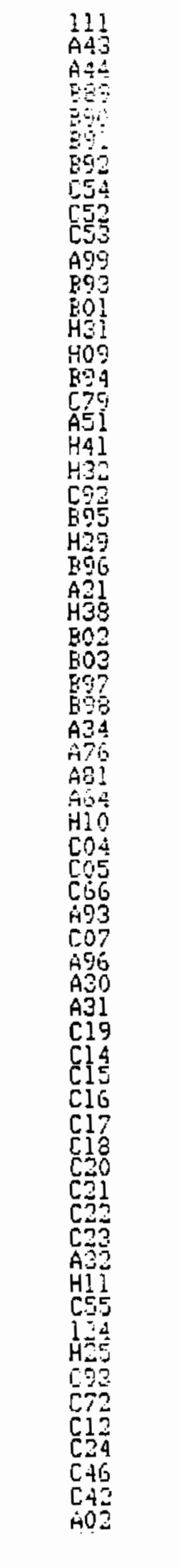 & 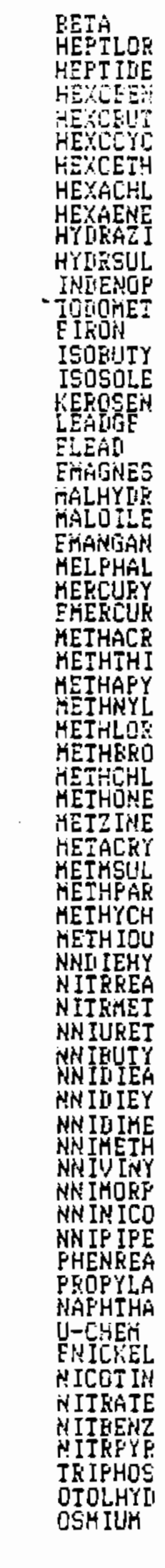 & 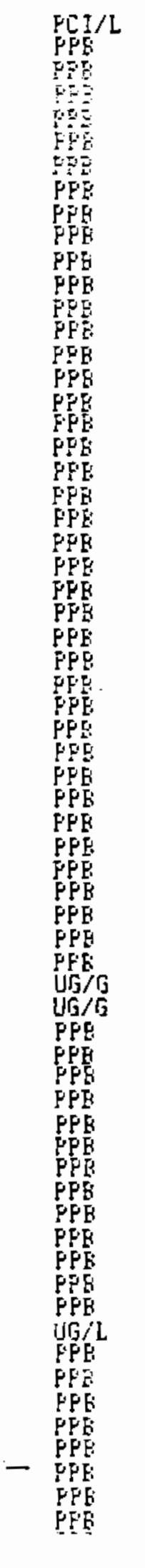 & 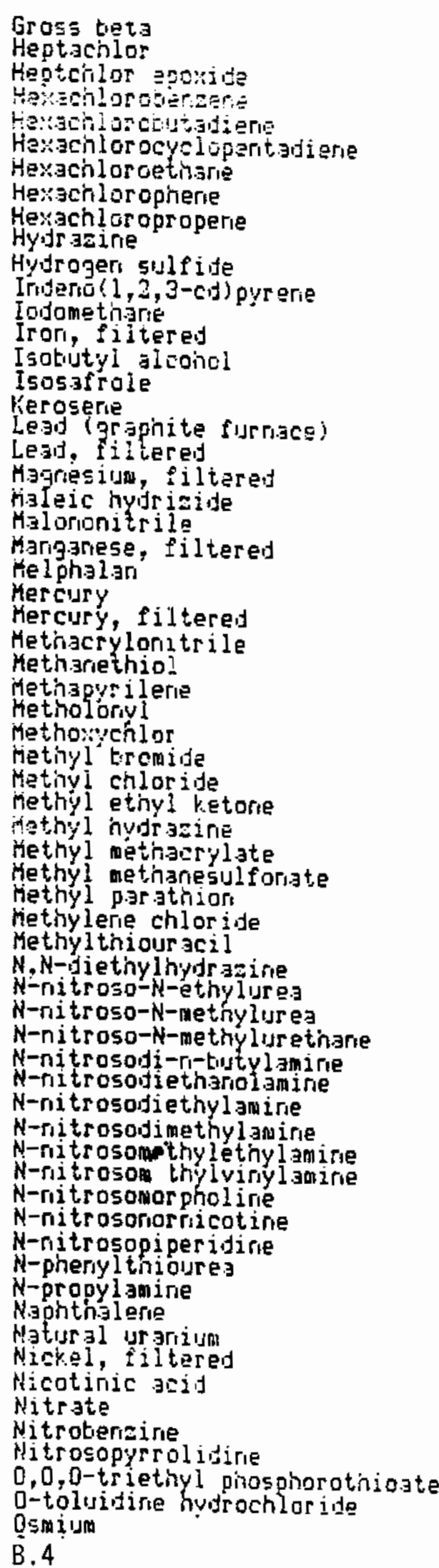 \\
\hline
\end{tabular}


IABLE B.1. (contd)

\begin{tabular}{|c|c|c|c|}
\hline $\begin{array}{c}\text { Corietituerit } \\
\text { Coje }\end{array}$ & $\begin{array}{c}\text { Coristituserit } \\
\text { Name }\end{array}$ & $\begin{array}{c}\text { Arıjoysis } \\
\text { infits }\end{array}$ & Constituent Lorrg ragle \\
\hline 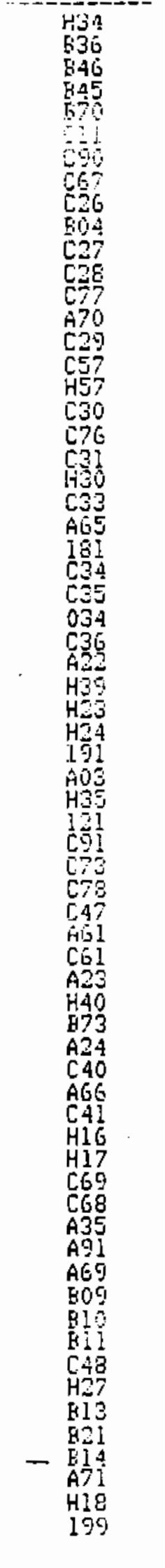 & 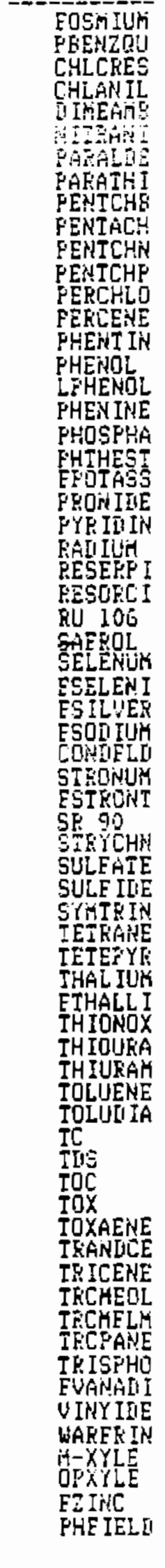 & 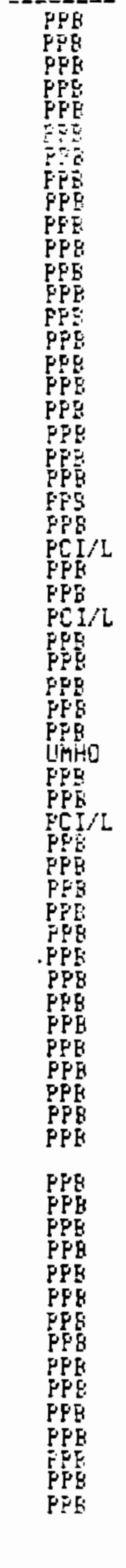 & 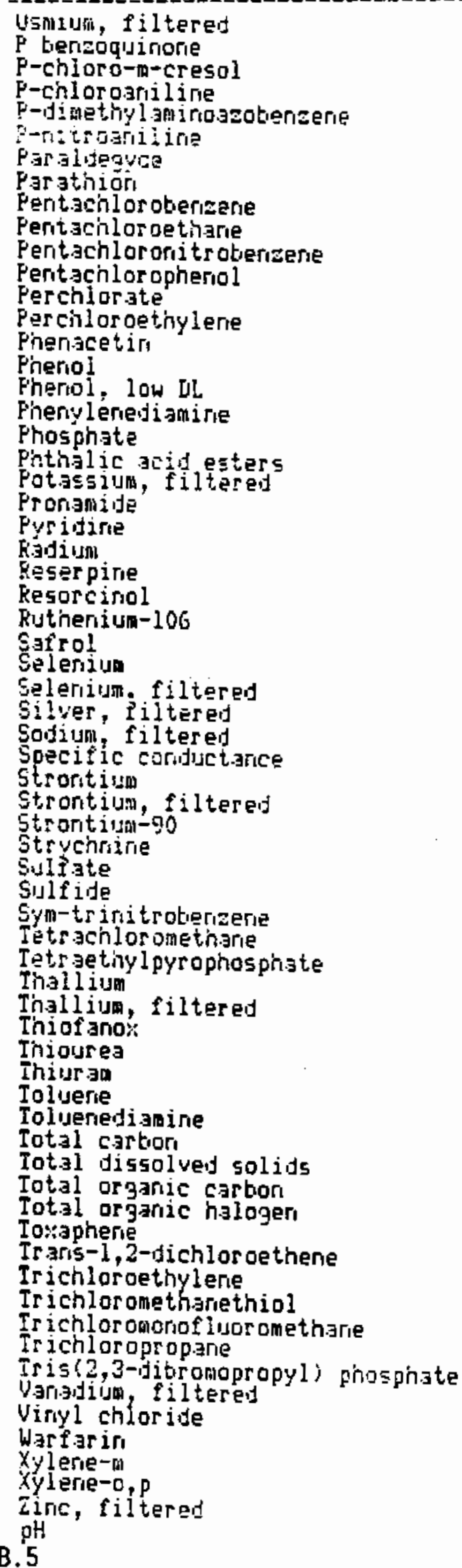 \\
\hline
\end{tabular}


IABLE_B.2. Chemistry Data for WelTs in 200-East Area

\begin{tabular}{|c|c|c|c|c|c|}
\hline $\begin{array}{l}\text { WELL } \\
\text { NAME }\end{array}$ & $\begin{array}{c}\text { COLLECTION } \\
\text { DATE }\end{array}$ & $\begin{array}{l}\text { CONSTI ITUENT } \\
\text { NAME }\end{array}$ & $\begin{array}{l}\text { LESS } \\
\text { THAN } \\
\text { FLAG }\end{array}$ & $\begin{array}{l}\text { ANALYSIS } \\
\text { VALUE }\end{array}$ & $\begin{array}{l}\text { ANALYSIS } \\
\text { UNITS }\end{array}$ \\
\hline $\begin{array}{l}2-E 27-8 \\
2-E 27-8 \\
2-E 27-8 \\
2-E 27-8 \\
2-E 27-8 \\
2-E 27-8 \\
2-E 27-8 \\
2-E 27-8 \\
2-E 27-8 \\
2-E 27-8 \\
2-E 27-8 \\
2-E 27-8 \\
2-E 27-8 \\
2-E 27-B \\
2-E 27-8 \\
2-E 27-8 \\
2-E 27-8 \\
2-E 27-8 \\
2-E 27-8\end{array}$ & $\begin{array}{l}9 / 22 / 88 \\
9 / 22 / 88 \\
9 / 22 / 88 \\
9 / 22 / 88 \\
9 / 22 / 88 \\
9 / 22 / 88 \\
9 / 22 / 88 \\
9 / 22 / 88 \\
9 / 22 / 88 \\
9 / 22 / 88 \\
9 / 22 / 88 \\
9 / 22 / 88 \\
9 / 22 / 88 \\
9 / 22 / 88 \\
9 / 22 / 88 \\
9 / 22 / 88 \\
9 / 22 / 88 \\
9 / 22 / 88 \\
9 / 22 / 88\end{array}$ & $\begin{array}{l}1,1,1-\mathrm{T} \\
1,1,2-\mathrm{T} \\
1,1-\mathrm{DIC} \\
1,2-\mathrm{DIC} \\
1 \text {-napha } \\
1112-\mathrm{tc} \\
1122 \text {-tc } \\
12 \text {-dben } \\
123 \text {-trp } \\
1234 \mathrm{TE} \\
1235 \mathrm{TE} \\
123 \mathrm{TRI} \\
13-\text { dben } \\
135 \mathrm{TRI} \\
14-\text { dben } \\
2,4,5-\mathrm{T} \\
2,4,5 \mathrm{TP} \\
2,4-0 \\
2-\text { napha }\end{array}$ & $\begin{array}{l}< \\
< \\
< \\
< \\
< \\
< \\
< \\
< \\
< \\
< \\
< \\
< \\
< \\
< \\
< \\
< \\
< \\
< \\
< \\
<\end{array}$ & $\begin{array}{l}5.0000 \mathrm{E}+00 \\
5.0000 \mathrm{E}+00 \\
1.0000 \mathrm{E}+01 \\
1.0000 \mathrm{E}+01 \\
1.0000 \mathrm{E}+0 \mathrm{I} \\
1.0000 \mathrm{E}+01 \\
1.0000 \mathrm{E}+0 \mathrm{I} \\
1.0000 \mathrm{E}+01 \\
1.0000 \mathrm{E}+01 \\
1.0000 \mathrm{E}+01 \\
1.0000 \mathrm{E}+01 \\
1.0000 \mathrm{E}+01 \\
1.0000 \mathrm{E}+01 \\
1.0000 \mathrm{E}+01 \\
1.0000 \mathrm{E}+01 \\
2.0000 \mathrm{E}+00 \\
2.0000 \mathrm{E}+00 \\
2.0000 \mathrm{E}+00 \\
1.0000 \mathrm{E}+01\end{array}$ & $\begin{array}{l}P P B \\
P P B \\
P P B \\
P P B \\
P P B \\
P P B \\
P P B \\
\text { PPB } \\
\text { PPB } \\
\text { PPB } \\
\text { PPB } \\
\text { PPB } \\
\text { PPB } \\
\text { PPB } \\
\text { PPB } \\
\text { PPB } \\
\text { PPB } \\
\text { PPB } \\
\text { PPB }\end{array}$ \\
\hline
\end{tabular}


IABLE B.2. (contd)

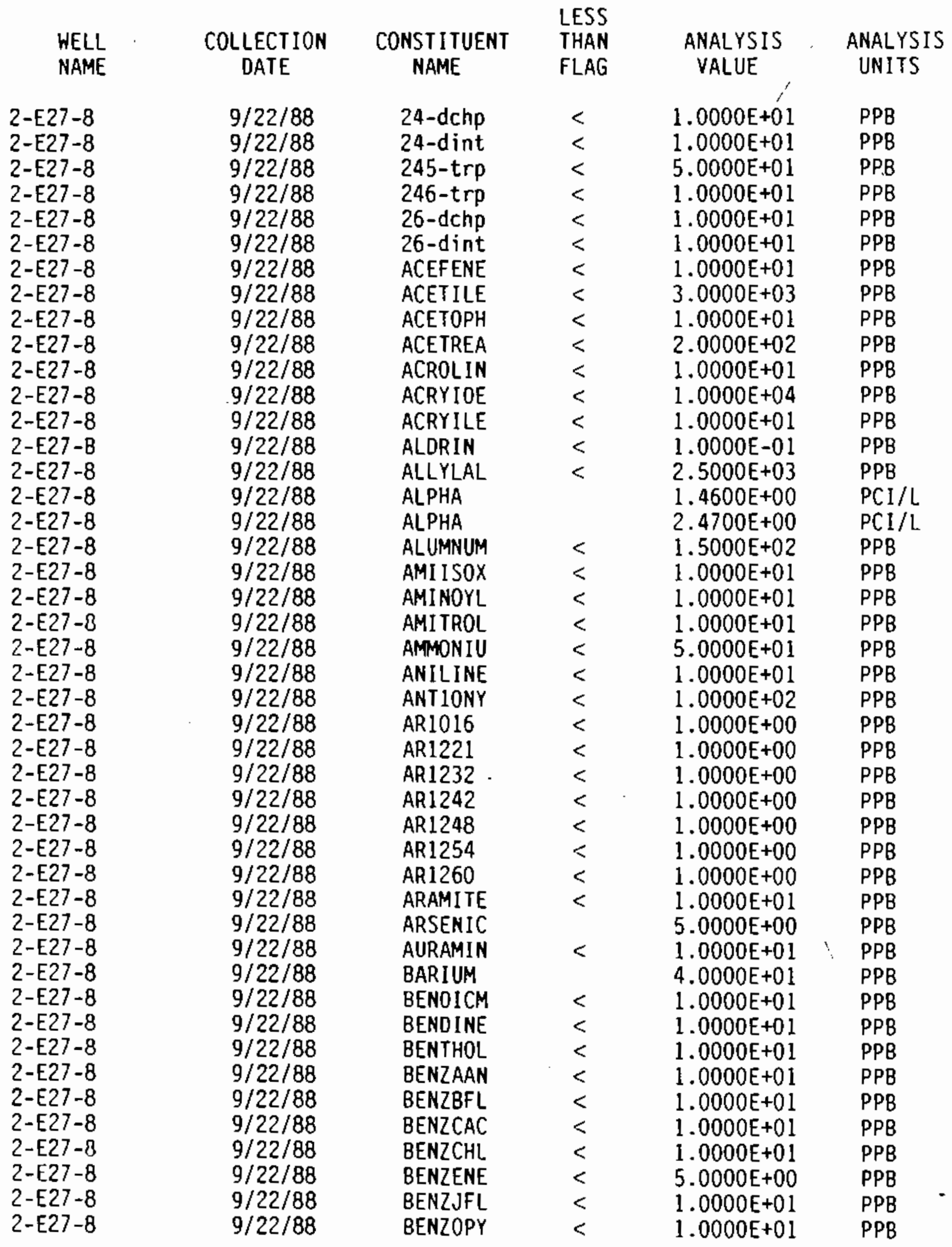


TABLE B.2. (contd)

\begin{tabular}{|c|c|c|c|c|c|}
\hline $\begin{array}{l}\text { WELL } \\
\text { NAME }\end{array}$ & $\begin{array}{c}\text { COLLECTION } \\
\text { DATE }\end{array}$ & $\begin{array}{l}\text { CONST ITUENT } \\
\text { NAME }\end{array}$ & $\begin{array}{l}\text { LESS } \\
\text { THAN } \\
\text { FLAG }\end{array}$ & $\begin{array}{l}\text { ANALYSIS } \\
\text { VALUE }\end{array}$ & $\begin{array}{l}\text { ANALYSIS } \\
\text { UNITS }\end{array}$ \\
\hline $\begin{array}{l}2-E 27-8 \\
2-E 27-8 \\
2-E 27-8 \\
2-E 27-8 \\
2-E 27-8 \\
2-E 27-8 \\
2-E 27-8 \\
2-E 27-8 \\
2-E 27-8 \\
2-E 27-8 \\
2-E 27-8 \\
2-E 27-8 \\
2-E 27-8 \\
2-E 27-8 \\
2-E 27-8 \\
2-E 27-8 \\
2-E 27-8 \\
2-E 27-8 \\
2-E 27-8 \\
2-E 27-8 \\
2-E 27-8 \\
2-E 27-8 \\
2-E 27-8 \\
2-E 27-8 \\
2-E 27-8 \\
2-E 27-8 \\
2-E 27-8 \\
2-E 27-8 \\
2-E 27-8 \\
2-E 27-8 \\
2-E 27-8 \\
2-E 27-8 \\
2-E 27-8 \\
2-E 27-8 \\
2-E 27-8 \\
2-E 27-8 \\
2-E 27-8 \\
2-E 27-8 \\
2-E 27-8 \\
2-E 27-8 \\
2-E 27-8 \\
2-E 27-8 \\
2-E 27-8 \\
2-E 27-8 \\
2-E 27-8\end{array}$ & $\begin{array}{l}9 / 22 / 88 \\
9 / 22 / 88 \\
9 / 22 / 88 \\
9 / 22 / 88 \\
9 / 22 / 88 \\
9 / 22 / 88 \\
9 / 22 / 88 \\
9 / 22 / 88 \\
9 / 22 / 88 \\
9 / 22 / 88 \\
9 / 22 / 88 \\
9 / 22 / 88 \\
9 / 22 / 88 \\
9 / 22 / 88 \\
9 / 22 / 88 \\
9 / 22 / 88 \\
9 / 22 / 88 \\
9 / 22 / 88 \\
9 / 22 / 88 \\
9 / 22 / 88 \\
9 / 22 / 88 \\
9 / 22 / 88 \\
9 / 22 / 88 \\
9 / 22 / 88 \\
9 / 22 / 88 \\
9 / 22 / 88 \\
9 / 22 / 88 \\
9 / 22 / 88 \\
9 / 22 / 88 \\
9 / 22 / 88 \\
9 / 22 / 88 \\
9 / 22 / 88 \\
9 / 22 / 88 \\
9 / 22 / 88 \\
9 / 22 / 88 \\
9 / 22 / 88 \\
9 / 22 / 88 \\
9 / 22 / 88 \\
9 / 22 / 88 \\
9 / 22 / 88 \\
9 / 22 / 88 \\
9 / 22 / 88 \\
9 / 22 / 88 \\
9 / 22 / 88 \\
9 / 22 / 88\end{array}$ & $\begin{array}{l}\text { BERYLUM } \\
\text { BETA } \\
\text { BETA } \\
\text { BISZCHE } \\
\text { BIS2CHM } \\
\text { BIS2EPH } \\
\text { BIS2ETH } \\
\text { BISTHER } \\
\text { BROMONE } \\
\text { BROMORM } \\
\text { BROPHEN } \\
\text { BUTBENP } \\
\text { BUTDINP } \\
\text { CADMIUM } \\
\text { CALCIUM } \\
\text { CARBIDE } \\
\text { CARBPHT } \\
\text { CHALETH } \\
\text { CHLACET } \\
\text { CHLANIL } \\
\text { CHLBENZ } \\
\text { CHLCRES } \\
\text { CHLEPOX } \\
\text { CHLFORM } \\
\text { CHLLATE } \\
\text { CHLNAPH } \\
\text { CHLNAPZ } \\
\text { CHLOANE } \\
\text { CHLOREA } \\
\text { CHLORID } \\
\text { CHLORID } \\
\text { CHLPHEN } \\
\text { CHLPROP } \\
\text { CHLTHER } \\
\text { CHMTHER } \\
\text { CHROMUM } \\
\text { CHRYSEN } \\
\text { CITRUSR } \\
\text { CO-60 } \\
\text { COLIFRM } \\
\text { CONDFLD } \\
\text { CONDLAB } \\
\text { CONDLAB } \\
\text { CONOLAB } \\
\text { CONDLAB }\end{array}$ & $\begin{array}{l} \\
< \\
< \\
< \\
< \\
< \\
< \\
< \\
< \\
< \\
< \\
< \\
< \\
< \\
< \\
< \\
< \\
< \\
< \\
< \\
< \\
< \\
< \\
< \\
< \\
< \\
< \\
< \\
< \\
< \\
< \\
< \\
< \\
<\end{array}$ & $\begin{array}{l}5.0000 \mathrm{E}+00 \\
1.0200 \mathrm{E}+01 \\
1.0500 \mathrm{E}+01 \\
1.0000 \mathrm{E}+01 \\
1.0000 \mathrm{E}+01 \\
1.0000 \mathrm{E}+01 \\
1.0000 \mathrm{E}+01 \\
1.0000 \mathrm{E}+01 \\
1.0000 \mathrm{E}+01 \\
1.0000 \mathrm{E}+01 \\
1.0000 \mathrm{E}+01 \\
1.0000 \mathrm{E}+01 \\
1.0000 \mathrm{E}+01 \\
2.0000 \mathrm{E}+00 \\
3.8800 \mathrm{E}+04 \\
1.0000 \mathrm{E}+01 \\
2.0000 \mathrm{E}+00 \\
1.0000 \mathrm{E}+01 \\
1.6000 \mathrm{E}+04 \\
1.0000 \mathrm{E}+01 \\
1.0000 \mathrm{E}+01 \\
1.0000 \mathrm{E}+01 \\
1.0000 \mathrm{E}+01 \\
5.0000 \mathrm{E}+00 \\
3.0000 \mathrm{E}+01 \\
1.0000 \mathrm{E}+01 \\
1.0000 \mathrm{E}+01 \\
1.0000 \mathrm{E}+00 \\
2.0000 \mathrm{E}+02 \\
6.0100 \mathrm{E}+03 \\
6.3700 \mathrm{E}+03 \\
1.0000 \mathrm{E}+01 \\
4.0000 \mathrm{E}+03 \\
1.0000 \mathrm{E}+01 \\
1.0000 \mathrm{E}+01 \\
2.6000 \mathrm{E}+01 \\
1.0000 \mathrm{E}+01 \\
1.0000 \mathrm{E}+03 \\
6.4000 \mathrm{E}+00 \\
2.2000 \mathrm{E}+00 \\
2.7200 \mathrm{E}+02 \\
3.3000 \mathrm{E}+02 \\
3.3100 \mathrm{E}+02 \\
3.3400 \mathrm{E}+02 \\
3.3500 \mathrm{E}+02\end{array}$ & $\begin{array}{l}\text { PPB } \\
\text { PCI/L } \\
\text { PCI/L } \\
\text { PPB } \\
\text { PPB } \\
\text { PPB } \\
\text { PPB } \\
\text { PPB } \\
\text { PPB } \\
\text { PPB } \\
\text { PPB } \\
\text { PPB } \\
\text { PPB } \\
\text { PPB } \\
\text { PPB } \\
\text { PPB } \\
\text { PPB } \\
\text { PPB } \\
\text { PPB } \\
\text { PPB } \\
\text { PPB } \\
\text { PPB } \\
\text { PPB } \\
\text { PPB } \\
\text { PPB } \\
\text { PPB } \\
\text { PPB } \\
\text { PPB } \\
\text { PPB } \\
\text { PPB } \\
\text { PPB } \\
\text { PPB } \\
\text { PPB } \\
\text { PPB } \\
\text { PPB } \\
\text { PPB } \\
\text { PPB } \\
\text { PPB } \\
\text { PCI/L } \\
\text { MPN } \\
\text { UMH0 } \\
\text { UMH0 } \\
\text { UMH0 } \\
\text { UMH0 } \\
\text { UMH0 }\end{array}$ \\
\hline
\end{tabular}


IABLE B.2. (contd)

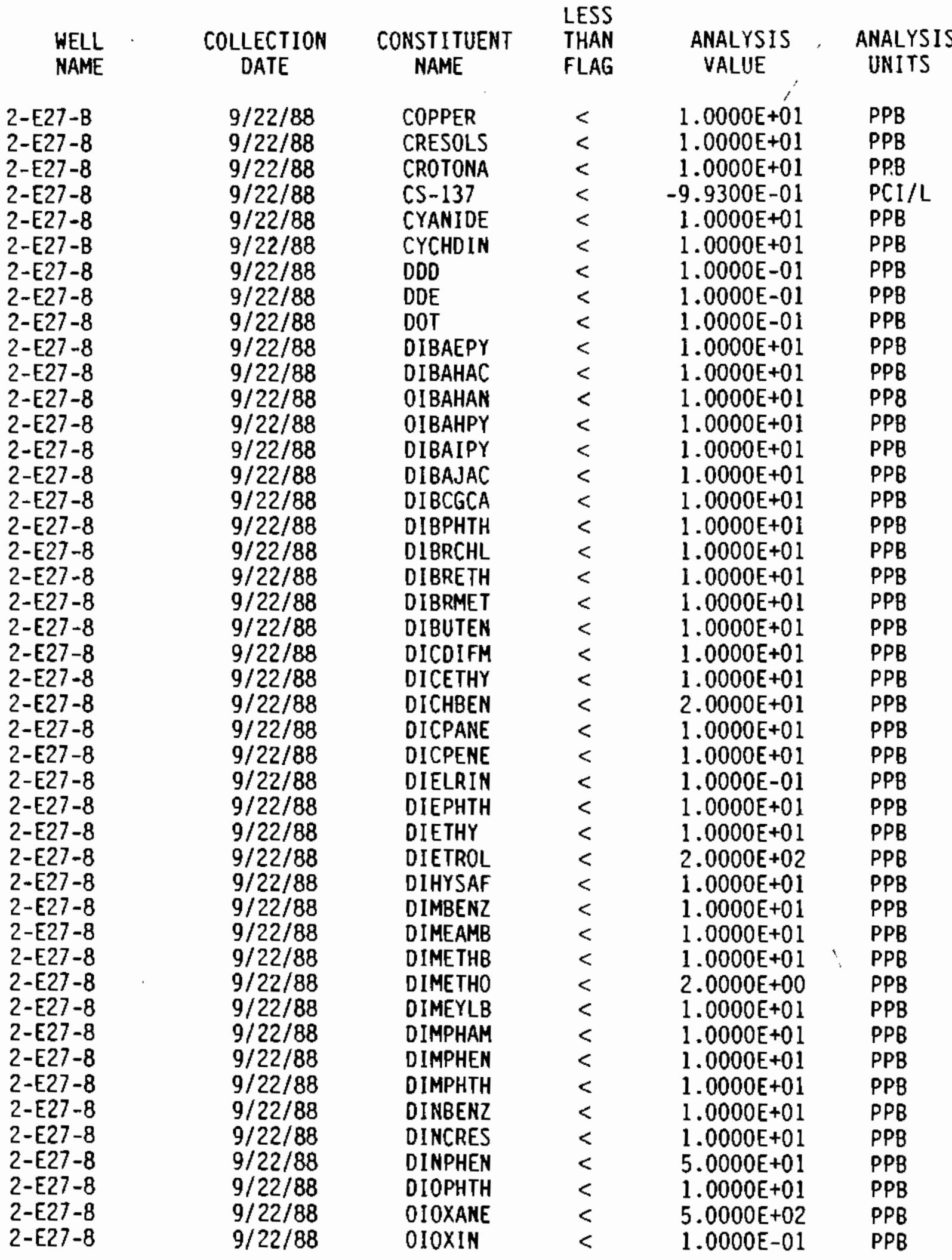


IABLE B.2. (contd)

\begin{tabular}{|c|c|c|c|c|c|}
\hline $\begin{array}{l}\text { WELL } \\
\text { NAME }\end{array}$ & $\begin{array}{l}\text { COLLECTION } \\
\text { DATE }\end{array}$ & $\begin{array}{l}\text { CONST I TUENT } \\
\text { NAME }\end{array}$ & $\begin{array}{l}\text { LESS } \\
\text { THAN } \\
\text { FLAG }\end{array}$ & $\begin{array}{l}\text { ANALYSIS } \\
\text { VALUE }\end{array}$ & $\begin{array}{l}\text { ANALYSIS } \\
\text { UNITS }\end{array}$ \\
\hline $\begin{array}{l}2-E 27-8 \\
2-E 27-8 \\
2-E 27-8 \\
2-E 27-8 \\
2-E 27-8 \\
2-E 27-8 \\
2-E 27-8 \\
2-E 27-8 \\
2-E 27-8 \\
2-E 27-8 \\
2-E 27-8 \\
2-E 27-8 \\
2-E 27-8 \\
2-E 27-8 \\
2-E 27-8 \\
2-E 27-8 \\
2-E 27-8 \\
2-E 27-8 \\
2-E 27-8 \\
2-E 27-8 \\
2-E 27-8 \\
2-E 27-8 \\
2-E 27-8 \\
2-E 27-8 \\
2-E 27-8 \\
2-E 27-8 \\
2-E 27-8 \\
2-E 27-8 \\
2-E 27-8 \\
2-E 27-8 \\
2-E 27-8 \\
2-E 27-8 \\
2-E 27-8 \\
2-E 27-8 \\
2-E 27-8 \\
2-E 27-8 \\
2-E 27-8 \\
2-E 27-8 \\
2-E 27-8 \\
2-E 27-8 \\
2-E 27-8 \\
2-E 27-8 \\
2-E 27-8 \\
2-E 27-8 \\
2-E 27-8\end{array}$ & $\begin{array}{l}9 / 22 / 88 \\
9 / 22 / 88 \\
9 / 22 / 88 \\
9 / 22 / 88 \\
9 / 22 / 88 \\
9 / 22 / 88 \\
9 / 22 / 88 \\
9 / 22 / 88 \\
9 / 22 / 88 \\
9 / 22 / 88 \\
9 / 22 / 88 \\
9 / 22 / 88 \\
9 / 22 / 88 \\
9 / 22 / 88 \\
9 / 22 / 88 \\
9 / 22 / 88 \\
9 / 22 / 88 \\
9 / 22 / 88 \\
9 / 22 / 88 \\
9 / 22 / 88 \\
9 / 22 / 88 \\
9 / 22 / 88 \\
9 / 22 / 88 \\
9 / 22 / 88 \\
9 / 22 / 88 \\
9 / 22 / 88 \\
9 / 22 / 88 \\
9 / 22 / 88 \\
9 / 22 / 88 \\
9 / 22 / 88 \\
9 / 22 / 88 \\
9 / 22 / 88 \\
9 / 22 / 88 \\
9 / 22 / 88 \\
9 / 22 / 88 \\
9 / 22 / 88 \\
9 / 22 / 88 \\
9 / 22 / 88 \\
9 / 22 / 88 \\
9 / 22 / 88 \\
9 / 22 / 88 \\
9 / 22 / 88 \\
9 / 22 / 88 \\
9 / 22 / 88 \\
9 / 22 / 88\end{array}$ & $\begin{array}{l}\text { DIPHAMI } \\
\text { DIPHHYD } \\
\text { DIPRNIT } \\
\text { DISULFO } \\
\text { ENDOI } \\
\text { ERDO2 } \\
\text { ENDRIN } \\
\text { ETHCARB } \\
\text { ETHCYAN } \\
\text { ETHMETH } \\
\text { ETHYETS } \\
\text { ETHMINE } \\
\text { ETHOXID } \\
\text { ETHYGLY } \\
\text { ETHYREA } \\
\text { FALUMIN } \\
\text { FANTIMO } \\
\text { FARSENI } \\
\text { FBARIUM } \\
\text { FBARIUM } \\
\text { FBERYLL } \\
\text { FCAOMIU } \\
\text { FCALCIU } \\
\text { FCALCIU } \\
\text { FCHROMI } \\
\text { FCOPPER } \\
\text { FIRON } \\
\text { FLEAD } \\
\text { FLUORAN } \\
\text { FLUORID } \\
\text { FMAGNES } \\
\text { FMAGNES } \\
\text { FMANGAN } \\
\text { FMERCUR } \\
\text { FNICKEL } \\
\text { FORMALN } \\
\text { FPOTASS } \\
\text { FPOTASS } \\
\text { FSELENI } \\
\text { FSILVER } \\
\text { FSODIUM } \\
\text { FSODIUM } \\
\text { FSTRONT } \\
\text { FSTRONT } \\
\text { FTHALLI }\end{array}$ & $\begin{array}{l}< \\
< \\
< \\
< \\
< \\
< \\
< \\
< \\
< \\
< \\
< \\
< \\
< \\
< \\
< \\
< \\
< \\
< \\
< \\
<\end{array}$ & $\begin{array}{l}1.0000 E+01 \\
1.0000 E+01 \\
1.0000 E+01 \\
2.0000 E+00 \\
1.0000 E-01 \\
1.0000 E-01 \\
1.0000 E-01 \\
5.0000 E+03 \\
2.0000 E+03 \\
1.0000 E+01 \\
1.0000 E+01 \\
1.0000 E+01 \\
3.0000 E+03 \\
1.0000 E+04 \\
2.0000 E+02 \\
1.5000 E+02 \\
1.0000 E+02 \\
8.0000 E+00 \\
3.9000 E+01 \\
4.1000 E+01 \\
5.0000 E+00 \\
2.0000 E+00 \\
3.9800 E+04 \\
4.1600 E+04 \\
1.0000 E+01 \\
1.0000 E+01 \\
3.0000 E+01 \\
5.0000 E+00 \\
1.0000 E+01 \\
5.0000 E+02 \\
1.1100 E+04 \\
1.1600 E+04 \\
5.0000 E+00 \\
1.0000 E-01 \\
1.0000 E+01 \\
5.0000 E+02 \\
7.6000 E+03 \\
7.9300 E+03 \\
5.0000 E+00 \\
1.0000 E+01 \\
1.6500 E+04 \\
1.6900 E+04 \\
1.9200 E+02 \\
1.9800 E+02 \\
5.0000 E+00\end{array}$ & 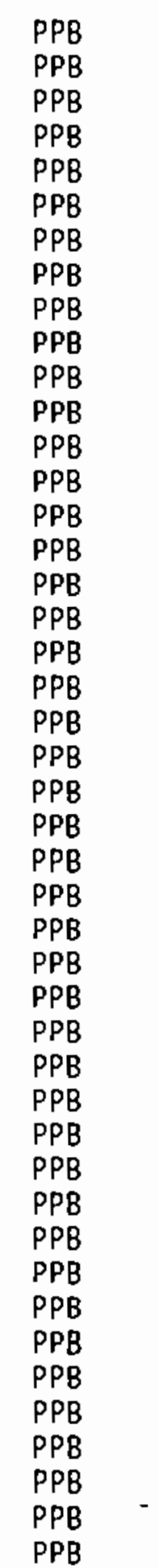 \\
\hline
\end{tabular}

B. 10 
IABLE B.2. (contd)

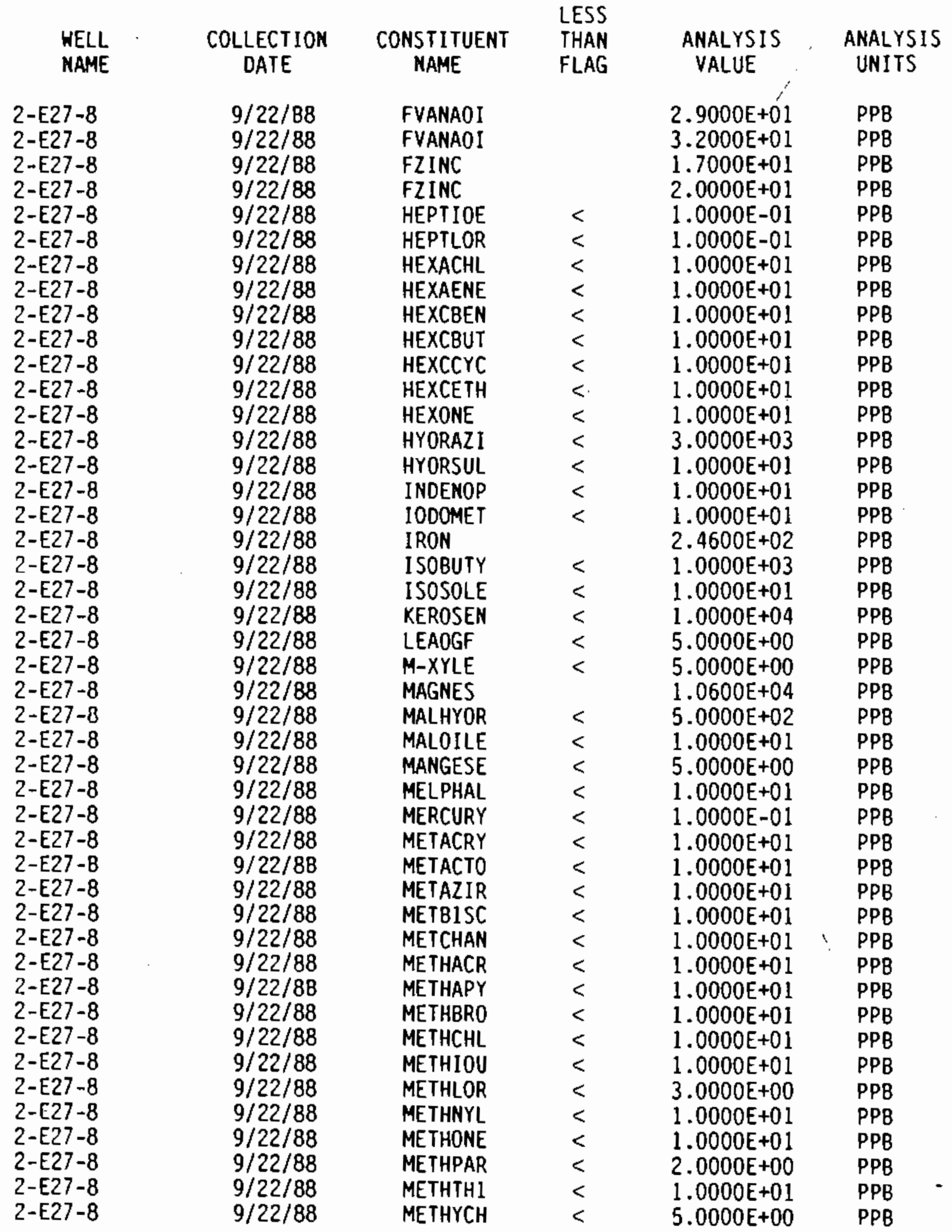

B. 11 
TABLE B.2. (contd)

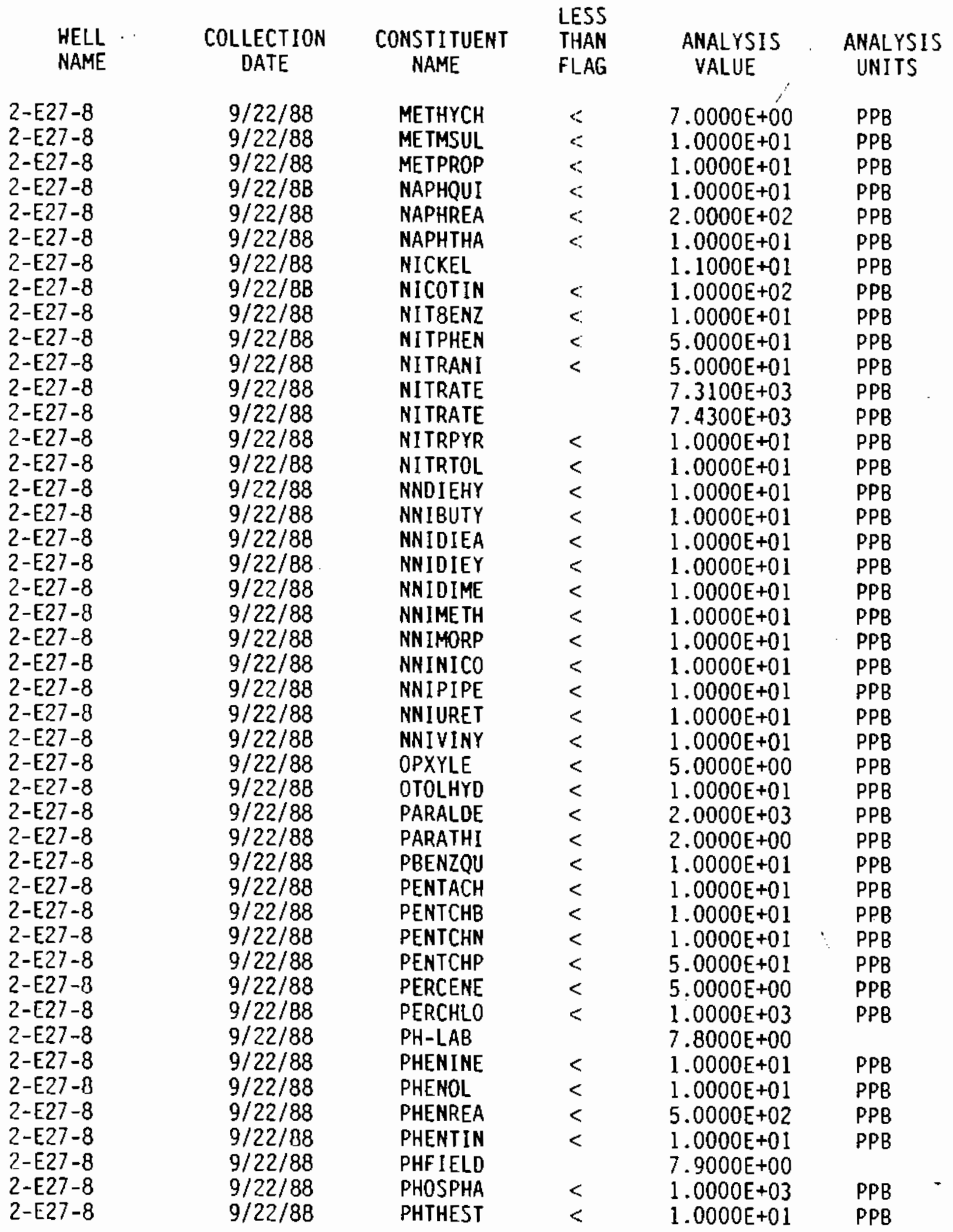

B. 12 
TABLE B.2. (contd)

\begin{tabular}{|c|c|c|c|c|c|}
\hline $\begin{array}{l}\text { WELL } \\
\text { NAME }\end{array}$ & $\begin{array}{l}\text { COLLECTION } \\
\text { DATE }\end{array}$ & $\begin{array}{l}\text { CONST ITUENT } \\
\text { NAME }\end{array}$ & $\begin{array}{l}\text { LESS } \\
\text { THAN } \\
\text { FLAG }\end{array}$ & $\begin{array}{l}\text { ANALYSIS } \\
\text { VALUE }\end{array}$ & $\begin{array}{l}\text { ANALYSIS } \\
\text { UNITS }\end{array}$ \\
\hline $\begin{array}{l}2-E 27-8 \\
2-E 27-8 \\
2-E 27-8 \\
2-E 27-8 \\
2-E 27-8 \\
2-E 27-8 \\
2-E 27-8 \\
2-E 27-8 \\
2-E 27-8 \\
2-E 27-8 \\
2-E 27-8 \\
2-E 27-8 \\
2-E 27-8 \\
2-E 27-8 \\
2-E 27-8 \\
2-E 27-8 \\
2-E 27-8 \\
2-E 27-8 \\
2-E 27-8 \\
2-E 27-8 \\
2-E 27-8 \\
2-E 27-8 \\
2-E 27-8 \\
2-E 27-8 \\
2-E 27-8 \\
2-E 27-8 \\
2-E 27-8 \\
2-E 27-8 \\
2-E 27-8 \\
2-E 27-8 \\
2-E 27-8 \\
2-E 27-8 \\
2-E 27-8 \\
2-E 27-8 \\
2-E 27-8 \\
2-E 27-8 \\
2-E 27-8 \\
2-E 27-8 \\
2-E 27-8 \\
2-E 27-8 \\
2-E 27-8 \\
2-E 27-8 \\
2-E 27-8 \\
2-E 27-8 \\
2-E 27-8\end{array}$ & $\begin{array}{l}9 / 22 / 88 \\
9 / 22 / 88 \\
9 / 22 / 88 \\
9 / 22 / 88 \\
9 / 22 / 88 \\
9 / 22 / 88 \\
9 / 22 / 88 \\
9 / 22 / 88 \\
9 / 22 / 88 \\
9 / 22 / 88 \\
9 / 22 / 88 \\
9 / 22 / 88 \\
9 / 22 / 88 \\
9 / 22 / 88 \\
9 / 22 / 88 \\
9 / 22 / 88 \\
9 / 22 / 88 \\
9 / 22 / 88 \\
9 / 22 / 88 \\
9 / 22 / 88 \\
9 / 22 / 88 \\
9 / 22 / 88 \\
9 / 22 / 88 \\
9 / 22 / 88 \\
9 / 22 / 88 \\
9 / 22 / 88 \\
9 / 22 / 88 \\
9 / 22 / 88 \\
9 / 22 / 88 \\
9 / 22 / 88 \\
9 / 22 / 88 \\
9 / 22 / 88 \\
9 / 22 / 88 \\
9 / 22 / 88 \\
9 / 22 / 88 \\
9 / 22 / 88 \\
9 / 22 / 88 \\
9 / 22 / 88 \\
9 / 22 / 88 \\
9 / 22 / 88 \\
9 / 22 / 88 \\
9 / 22 / 88 \\
9 / 22 / 88 \\
9 / 22 / 88 \\
9 / 22 / 88\end{array}$ & $\begin{array}{l}\text { PICOLIN } \\
\text { POTASUM } \\
\text { PRONIDE } \\
\text { PROPYLA } \\
\text { PROPYNO } \\
\text { PYRIDIN } \\
\text { RAOIUM } \\
\text { RESERPI } \\
\text { RESORCI } \\
\text { RU-106 } \\
\text { SAFROL } \\
\text { SELENUM } \\
\text { SILVER } \\
\text { SODIUM } \\
\text { SR 9O } \\
\text { STRONUM } \\
\text { STRYCHN } \\
\text { SULFATE } \\
\text { SULFATE } \\
\text { SULFIDE } \\
\text { SYMTRIN } \\
\text { TC } \\
\text { TC-99 } \\
\text { TETEPYR } \\
\text { TETRANE } \\
\text { TETRCHB } \\
\text { TETRCHP } \\
\text { THALIUM } \\
\text { THIONOX } \\
\text { THIOURA } \\
\text { THIURAM } \\
\text { TOC } \\
\text { TOC } \\
\text { TOC } \\
\text { TOC } \\
\text { TOLUOIA } \\
\text { TOLUENE } \\
\text { TOXAENE } \\
\text { TOXLOL } \\
\text { TOXLOL } \\
\text { TOXLDL } \\
\text { TRANOCE } \\
\text { TRCMEOL } \\
\text { TRCMFLM } \\
\text { TRCPANE }\end{array}$ & $\begin{array}{l}< \\
< \\
< \\
< \\
< \\
< \\
< \\
< \\
< \\
< \\
< \\
< \\
< \\
< \\
< \\
< \\
< \\
< \\
< \\
< \\
< \\
< \\
< \\
< \\
< \\
< \\
< \\
< \\
<\end{array}$ & $\begin{array}{r}1.0000 E+01 \\
7.0000 E+03 \\
1.0000 E+01 \\
1.0000 E+04 \\
8.0000 E+03 \\
5.0000 E+02 \\
1.4600 E-01 \\
1.0000 E+01 \\
1.0000 E+01 \\
-1.1100 E+01 \\
1.0000 E+01 \\
5.0000 E+00 \\
1.0000 E+01 \\
1.5600 E+04 \\
9.0200 E-02 \\
1.8600 E+02 \\
5.0000 E+01 \\
4.6200 E+04 \\
4.7300 E+04 \\
1.0000 E+03 \\
1.0000 E+01 \\
1.9900 E+04 \\
1.1300 E+00 \\
2.0000 E+00 \\
5.0000 E+00 \\
1.0000 E+01 \\
1.0000 E+01 \\
5.0000 E+00 \\
1.0000 E+01 \\
2.0000 E+02 \\
1.0000 E+01 \\
4.000 E E+02 \\
5.0000 E+02 \\
6.0000 E+02 \\
7.0000 E+02 \\
1.0000 E+01 \\
5.0000 E+00 \\
1.0000 E+00 \\
4.0000 E+00 \\
5.0000 E+00 \\
7.0000 E+00 \\
1.0000 E+01 \\
1.0000 E+01 \\
1.0000 E+01 \\
1.0000 E+01\end{array}$ & $\begin{array}{l}P P B \\
P P B \\
P P B \\
P P B \\
P P B \\
P P B \\
P C I / L \\
P P B \\
P P B \\
P C 1 / L \\
P P B \\
P P B \\
P P B \\
P P B \\
P C I / L \\
P P B \\
P P B \\
P P B \\
P P B \\
P P B \\
P P B \\
P P B \\
P C I / L \\
P P B \\
P P B \\
P P B \\
P P B \\
P P B \\
P P B \\
P P B \\
P P B \\
P P B \\
P P B \\
P P B \\
P P B \\
P P B \\
P P B \\
P P B \\
P P B \\
P P B \\
P P B \\
P P B \\
P P B \\
P P B \\
P P B\end{array}$ \\
\hline & & & & & \\
\hline
\end{tabular}


IABLE B.2. (contd)

\begin{tabular}{|c|c|c|c|c|c|}
\hline $\begin{array}{l}\text { WELL } \\
\text { NAME }\end{array}$ & $\begin{array}{c}\text { COLLECTION } \\
\text { DATE }\end{array}$ & $\begin{array}{l}\text { CONST I TUENT } \\
\text { NAME }\end{array}$ & $\begin{array}{l}\text { LESS } \\
\text { THAN } \\
\text { FLAG }\end{array}$ & $\begin{array}{l}\text { ANALYSIS } \\
\text { VALUE }\end{array}$ & $\begin{array}{l}\text { ANALYSIS } \\
\text { UNITS }\end{array}$ \\
\hline $\begin{array}{l}2-E 27-8 \\
2-E 27-8 \\
2-E 27-8 \\
2-E 27-8 \\
2-E 27-8 \\
2-E 27-8 \\
2-E 27-8 \\
2-E 27-8 \\
2-E 27-8 \\
2-E 27-8 \\
2-E 27-8 \\
2-E 27-8 \\
2-E 27-8 \\
2-E 27-8 \\
2-E 27-8 \\
2-E 27-8\end{array}$ & $\begin{array}{l}9 / 22 / 88 \\
9 / 22 / 88 \\
9 / 22 / 88 \\
9 / 22 / 88 \\
9 / 22 / 88 \\
9 / 22 / 88 \\
9 / 22 / 88 \\
9 / 22 / 88 \\
9 / 22 / 88 \\
9 / 22 / 88 \\
9 / 22 / 88 \\
9 / 22 / 88 \\
9 / 22 / 88 \\
9 / 22 / 88 \\
9 / 22 / 88 \\
9 / 22 / 88\end{array}$ & $\begin{array}{l}\text { TRIBUPH } \\
\text { TRICENE } \\
\text { TRICHLB } \\
\text { TRIPHOS } \\
\text { TRISPHO } \\
\text { TRITIUM } \\
\text { U-CHEM } \\
\text { U-CHEM } \\
\text { VANADUM } \\
\text { VINYIDE } \\
\text { WARFRIN } \\
\text { ZINC } \\
\text { a-BHC } \\
\text { b-BHC } \\
\text { d-BHC } \\
\text { פ-DHC . }\end{array}$ & $\begin{array}{l}< \\
< \\
< \\
< \\
< \\
<\end{array}$ & $\begin{array}{l}1.0000 E+01 \\
5.0000 E+00 \\
1.0000 E+01 \\
1.0000 E+01 \\
1.0000 E+01 \\
1.0500 E+04 \\
2.6000 E+00 \\
2.8500 E+00 \\
2.8000 E+01 \\
1.0000 E+01 \\
1.0000 E+01 \\
2.8000 E+01 \\
1.0000 E-01 \\
1.0000 E-01 \\
1.0000 E-01 \\
1.0000 E-01\end{array}$ & $\begin{array}{l}P P B \\
P P B \\
P P B \\
P P B \\
P P B \\
P C I / L \\
U G / L \\
U G / L \\
P P B \\
P P B \\
P P B \\
P P B \\
P P B \\
P P B \\
P P B \\
P P D\end{array}$ \\
\hline
\end{tabular}


IABLE B.2. (contd)

\begin{tabular}{|c|c|c|c|c|c|}
\hline $\begin{array}{l}\text { WELL } \\
\text { NAME }\end{array}$ & $\begin{array}{c}\text { COLLECTION } \\
\text { DATE }\end{array}$ & $\begin{array}{l}\text { CONSTITUENT } \\
\text { NAME }\end{array}$ & $\begin{array}{l}\text { LESS } \\
\text { THAN } \\
\text { FLAG }\end{array}$ & $\begin{array}{l}\text { ANALYSIS } \\
\text { VALUE }\end{array}$ & $\begin{array}{l}\text { ANALYSIS } \\
\text { UNITS }\end{array}$ \\
\hline $\begin{array}{l}2-E 34-1 \\
2-E 34-1 \\
2-E 34-1 \\
2-E 34-1 \\
2-E 34-1 \\
2-E 34-1 \\
2-E 34-1 \\
2-E 34-1 \\
2-E 34-1 \\
2-E 34-1 \\
2-E 34-1 \\
2-E 34-1 \\
2-E 34-1 \\
2-E 34-1 \\
2-E 34-1 \\
2-E 34-1 \\
2-E 34-1\end{array}$ & $\begin{array}{l}1 / 21 / 85 \\
1 / 21 / 85 \\
1 / 21 / 85 \\
1 / 21 / 85 \\
1 / 21 / 85 \\
1 / 21 / 85 \\
1 / 21 / 85 \\
2 / 11 / 85 \\
2 / 12 / 85 \\
2 / 12 / 85 \\
2 / 12 / 85 \\
2 / 12 / 85 \\
2 / 12 / 85 \\
2 / 12 / 85 \\
3 / 18 / 85 \\
3 / 18 / 85 \\
3 / 18 / 85\end{array}$ & $\begin{array}{l}\text { ALPHA } \\
\text { BETA } \\
\text { CO-60 } \\
\text { C5-137 } \\
\text { N03-10N } \\
\text { RU-106 } \\
\text { TRITIUM } \\
\text { N03-10N } \\
\text { ALPHA } \\
\text { BETA } \\
\text { CO-60 } \\
\text { CS-I37 } \\
\text { RU-106 } \\
\text { TRITIUM } \\
\text { ALPHA } \\
\text { BETA } \\
\text { CO-60 }\end{array}$ & & $\begin{array}{r}1.6500 E+00 \\
8.7600 E+00 \\
4.5100 E+00 \\
-3.7800 E+00 \\
1.4000 E+01 \\
1.4400 E+01 \\
3.9000 E+02 \\
1.4000 E+01 \\
3.0900 E+00 \\
1.0000 E+01 \\
3.0500 E+00 \\
3.2000 E-01 \\
-3.0100 E+01 \\
1.8900 E+02 \\
2.5900 E+00 \\
7.8500 E+00 \\
-5.0900 E+00\end{array}$ & $\begin{array}{l}P C I / L \\
P C I / L \\
P C I / L \\
P C I / L \\
M G / L \\
P C I / L \\
P C I / L \\
M G / L \\
P C I / L \\
P C I / L \\
P C I / L \\
P C I / L \\
P C I / L \\
P C I / L \\
P C I / L \\
P C I / L \\
P C I / L\end{array}$ \\
\hline
\end{tabular}


TABLE B.2. (contd)

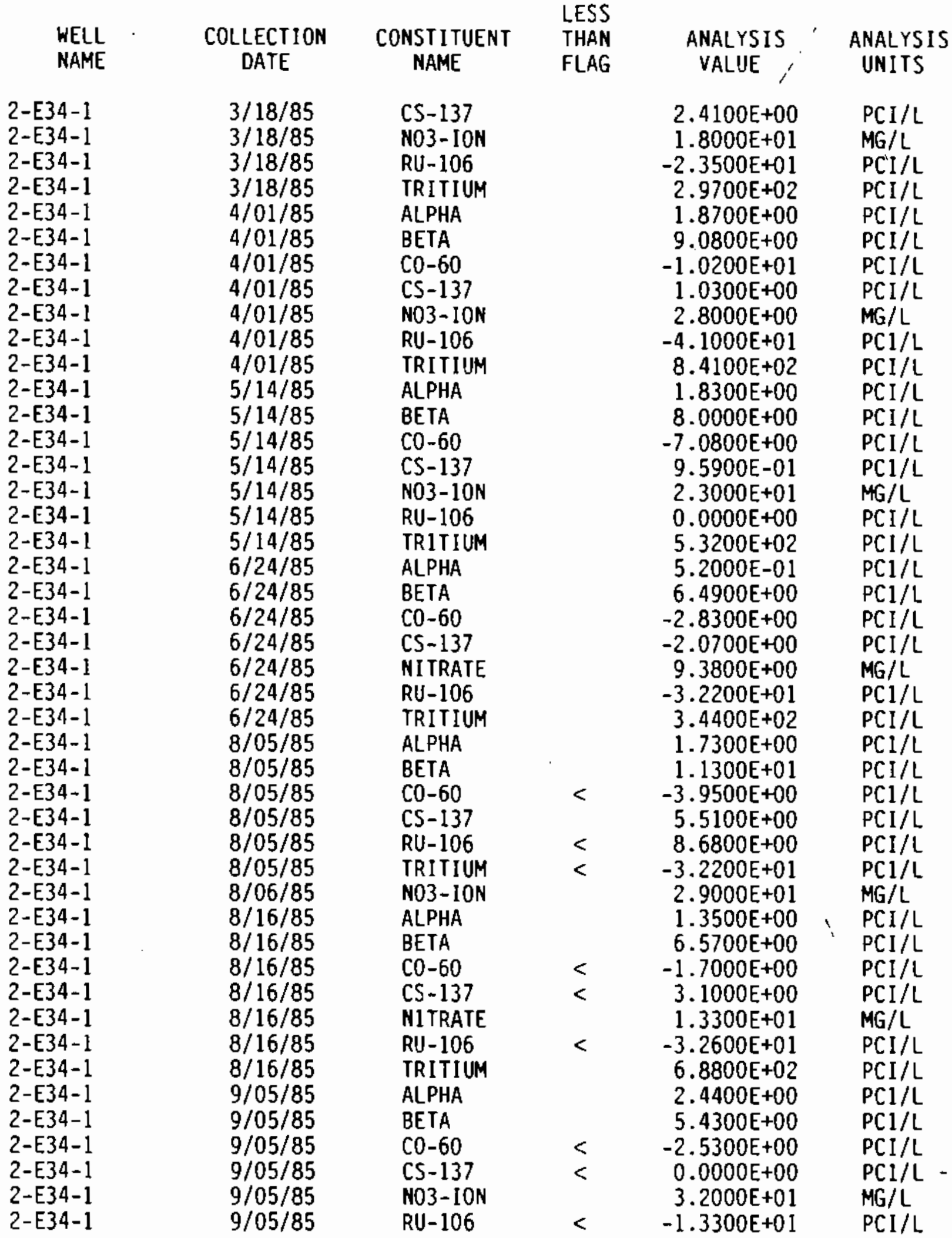


TABLE B.2. (contd)

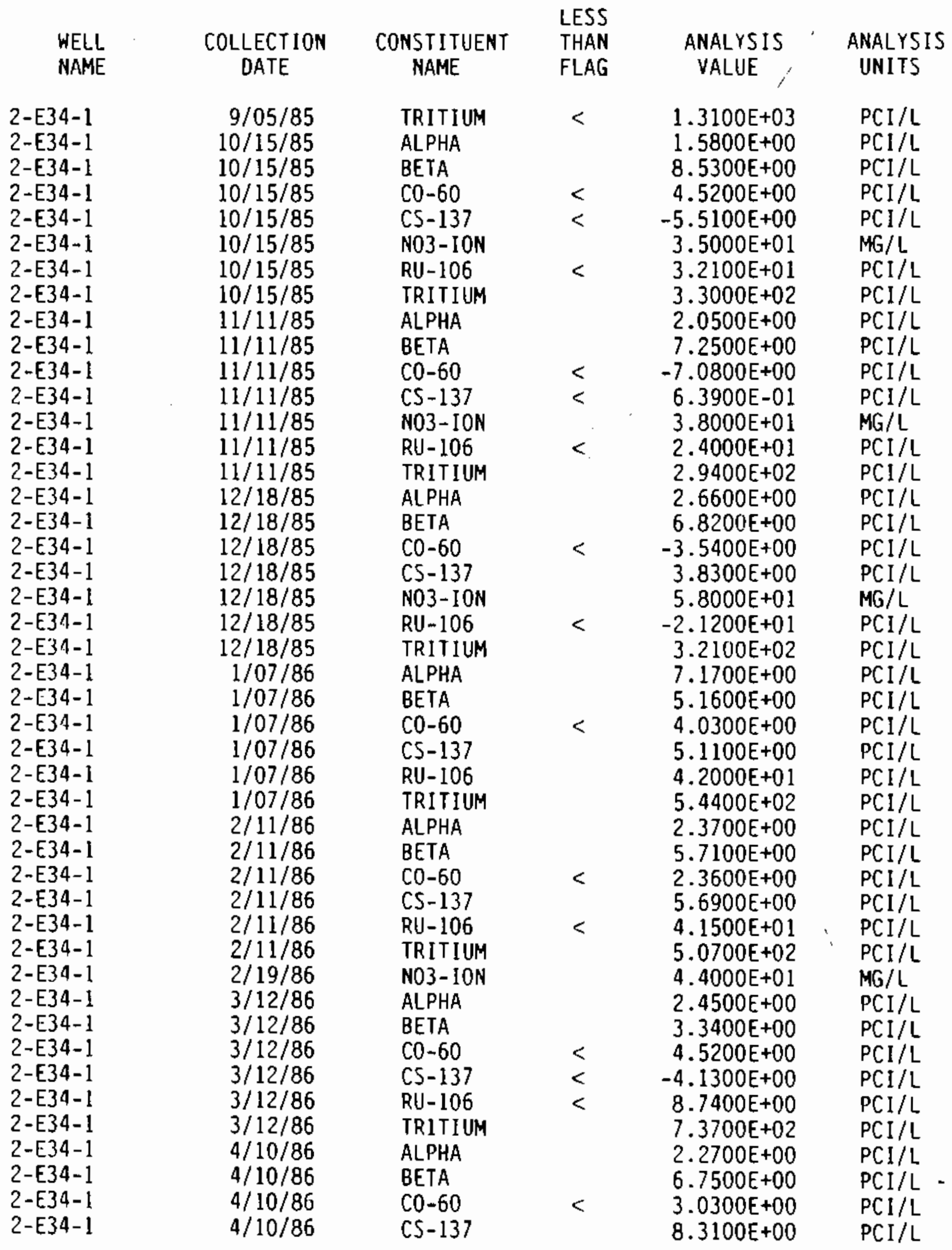


TABLE B.2. (contd)

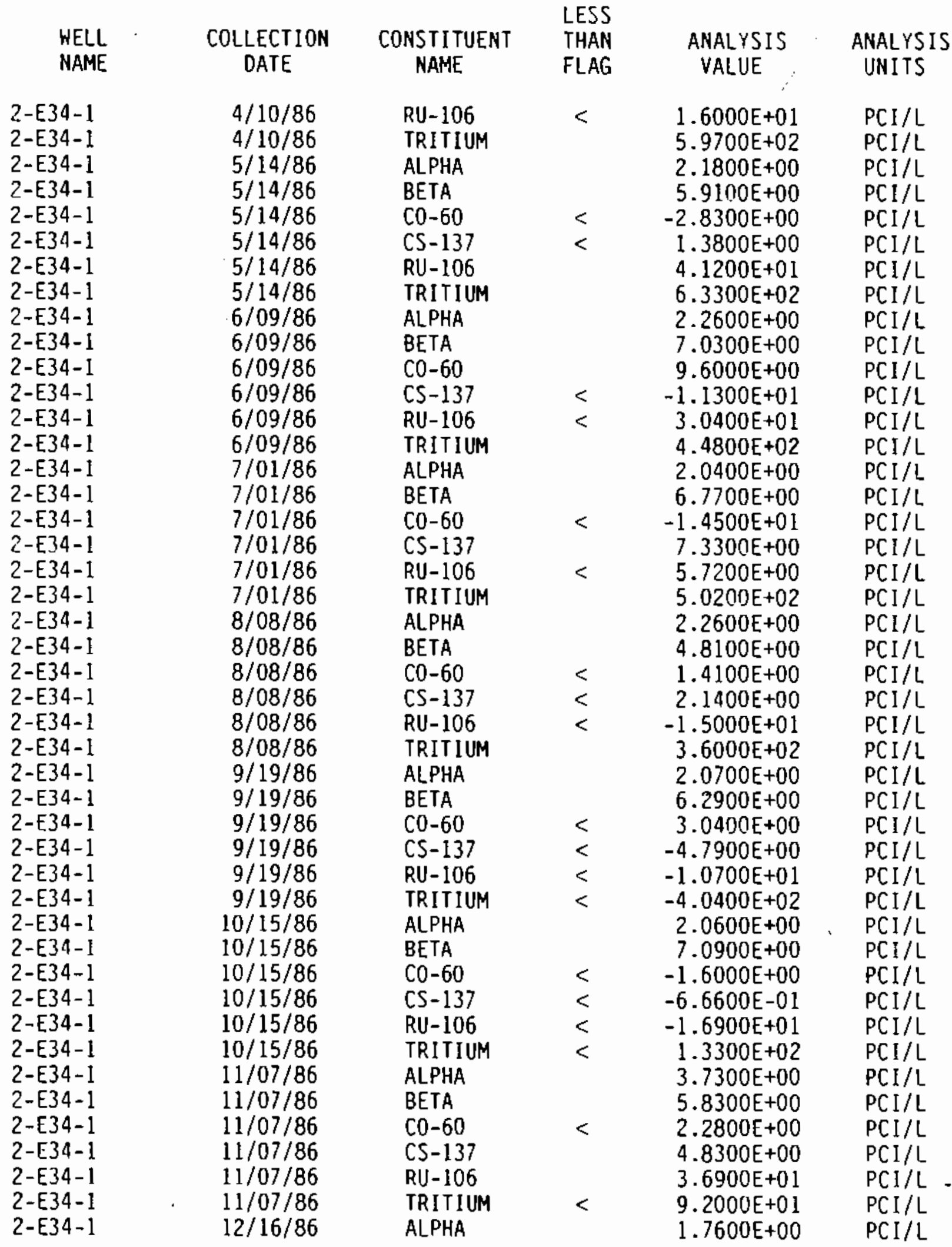


IABLE B.2. (contd)

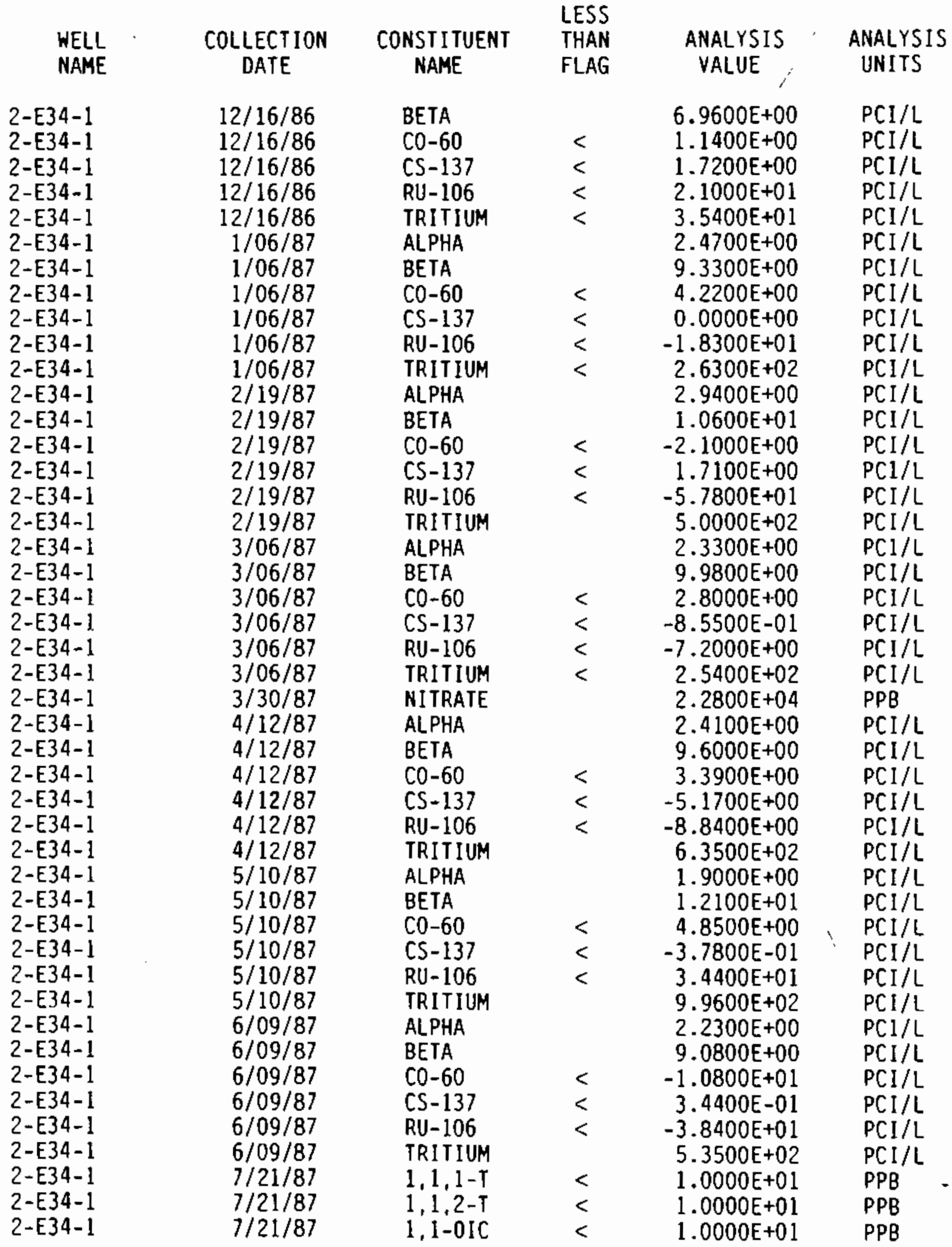


IABLE B.2. (contd)

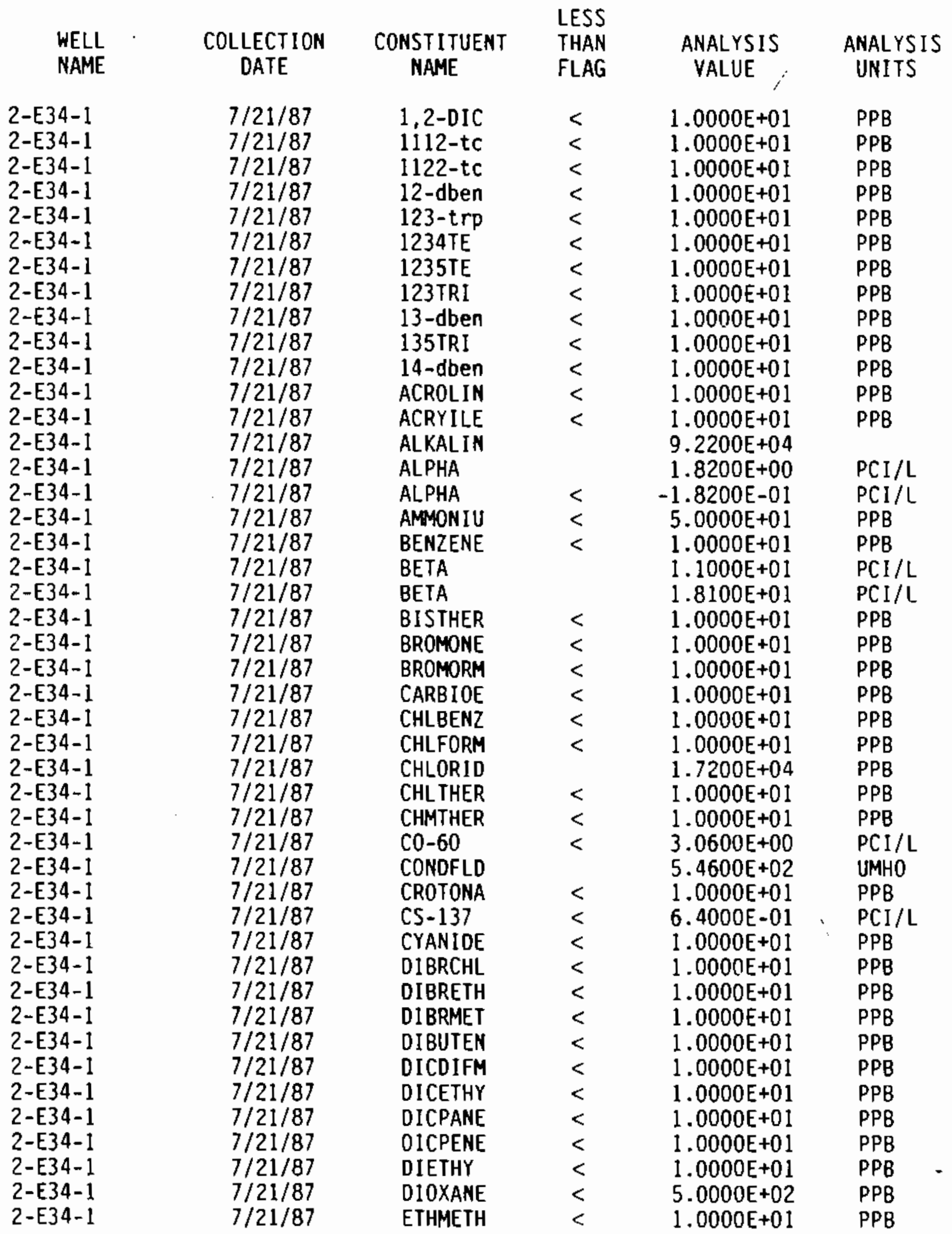


TABLE B.2. (contd)

\begin{tabular}{|c|c|c|c|c|c|}
\hline $\begin{array}{l}\text { WELL } \\
\text { NAME }\end{array}$ & $\begin{array}{c}\text { COLLECTION } \\
\text { DATE }\end{array}$ & $\begin{array}{l}\text { CONST ITUENT } \\
\text { NAME }\end{array}$ & $\begin{array}{l}\text { LESS } \\
\text { THAN } \\
\text { FLAG }\end{array}$ & $\begin{array}{l}\text { ANALYSIS } \\
\text { VALUE }\end{array}$ & $\begin{array}{l}\text { ANALYSIS } \\
\text { UNITS }\end{array}$ \\
\hline $\begin{array}{l}2-E 34-1 \\
2-E 34-1 \\
2-E 34-1 \\
2-E 34-1 \\
2-E 34-1 \\
2-E 34-1 \\
2-E 34-1 \\
2-E 34-1 \\
2-E 34-1 \\
2-E 34-1 \\
2-E 34-1 \\
2-E 34-1 \\
2-E 34-1 \\
2-E 34-1 \\
2-E 34-1 \\
2-E 34-1 \\
2-E 34-1 \\
2-E 34-1 \\
2-E 34-1 \\
2-E 34-1 \\
2-E 34-1 \\
2-E 34-1 \\
2-E 34-1 \\
2-E 34-1 \\
2-E 34-1 \\
2-E 34-1 \\
2-E 34-1 \\
2-E 34-1 \\
2-E 34-1 \\
2-E 34-1 \\
2-E 34-1 \\
2-E 34-1 \\
2-E 34-1 \\
2-E 34-1 \\
2-E 34-1 \\
2-E 34-1 \\
2-E 34-1 \\
2-E 34-1 \\
2-E 34-1 \\
2-E 34-1 \\
2-E 34-1 \\
2-E 34-1 \\
2-E 34-1 \\
2-E 34-1 \\
2-E 34-1\end{array}$ & $\begin{array}{l}7 / 21 / 87 \\
7 / 21 / 87 \\
7 / 21 / 87 \\
7 / 21 / 87 \\
7 / 21 / 87 \\
7 / 21 / 87 \\
7 / 21 / 87 \\
7 / 21 / 87 \\
7 / 21 / 87 \\
7 / 21 / 87 \\
7 / 21 / 87 \\
7 / 21 / 87 \\
7 / 21 / 87 \\
7 / 21 / 87 \\
7 / 21 / 87 \\
7 / 21 / 87 \\
7 / 21 / 87 \\
7 / 21 / 87 \\
7 / 21 / 87 \\
7 / 21 / 87 \\
7 / 21 / 87 \\
7 / 21 / 87 \\
7 / 21 / 87 \\
7 / 21 / 87 \\
7 / 21 / 87 \\
7 / 21 / 87 \\
7 / 21 / 87 \\
7 / 21 / 87 \\
7 / 21 / 87 \\
7 / 21 / 87 \\
7 / 21 / 87 \\
7 / 21 / 87 \\
7 / 21 / 87 \\
7 / 21 / 87 \\
7 / 21 / 87 \\
7 / 21 / 87 \\
7 / 21 / 87 \\
7 / 21 / 87 \\
7 / 21 / 87 \\
7 / 21 / 87 \\
7 / 21 / 87 \\
7 / 21 / 87 \\
7 / 21 / 87 \\
7 / 21 / 87 \\
7 / 21 / 87\end{array}$ & $\begin{array}{l}\text { FALUMIN } \\
\text { FANTIMO } \\
\text { FARSENI } \\
\text { FBARIUM } \\
\text { FBERYLL } \\
\text { FCADMIU } \\
\text { FCALCIU } \\
\text { FCHROMI } \\
\text { FCOPPER } \\
\text { FIRON } \\
\text { FLEAD } \\
\text { FLUORID } \\
\text { FMAGNES } \\
\text { FMANGAN } \\
\text { FMERCUR } \\
\text { FNICKEL } \\
\text { FORMALN } \\
\text { FOSMIUM } \\
\text { FPOTASS } \\
\text { FSELENI } \\
\text { FSILVER } \\
\text { FSODIUM } \\
\text { FSTRONT } \\
\text { FVANADI } \\
\text { FZINC } \\
\text { HEXACHL } \\
\text { HEXCBEN } \\
\text { HYDRSUL } \\
\text { IOOOMET } \\
\text { KEROSEN } \\
\text { LFLUORD } \\
\text { LHYORAZ } \\
\text { M-XYLE } \\
\text { METACRY } \\
\text { METHACR } \\
\text { METHBRO } \\
\text { METHCHL } \\
\text { METHONE } \\
\text { METHTHI } \\
\text { METHYCH } \\
\text { NAPHTHA } \\
\text { NITRATE } \\
\text { NNOIEHY } \\
\text { OPXYLE } \\
\text { PENTACH }\end{array}$ & $\begin{array}{l}< \\
< \\
< \\
< \\
< \\
< \\
< \\
< \\
< \\
< \\
< \\
< \\
< \\
< \\
< \\
< \\
< \\
< \\
<\end{array}$ & $\begin{array}{l}1.5000 \mathrm{E}+02 \\
1.0000 \mathrm{E}+02 \\
5.0000 \mathrm{E}+00 \\
3.6000 \mathrm{E}+01 \\
5.0000 \mathrm{E}+00 \\
2.0000 \mathrm{E}+00 \\
5.8100 \mathrm{E}+04 \\
3.0000 \mathrm{E}+00 \\
1.0000 \mathrm{E}+01 \\
1.1800 \mathrm{E}+02 \\
5.0000 \mathrm{E}+00 \\
6.8200 \mathrm{E}+02 \\
1.7200 \mathrm{E}+04 \\
1.2000 \mathrm{E}+01 \\
1.0000 \mathrm{E}-01 \\
1.0000 \mathrm{E}+01 \\
5.0000 \mathrm{E}+02 \\
3.0000 \mathrm{E}+02 \\
8.0100 \mathrm{E}+03 \\
5.0000 \mathrm{E}+00 \\
1.0000 \mathrm{E}+01 \\
2.4900 \mathrm{E}+04 \\
3.0500 \mathrm{E}+02 \\
1.3000 \mathrm{E}+01 \\
1.7000 \mathrm{E}+01 \\
1.0000 \mathrm{E}+01 \\
1.0000 \mathrm{E}+01 \\
1.0000 \mathrm{E}+01 \\
1.0000 \mathrm{E}+01 \\
1.0000 \mathrm{E}+04 \\
4.7000 \mathrm{E}+02 \\
3.0000 \mathrm{E}+01 \\
1.0000 \mathrm{E}+01 \\
1.0000 \mathrm{E}+01 \\
1.0000 \mathrm{E}+01 \\
1.0000 \mathrm{E}+01 \\
1.0000 \mathrm{E}+01 \\
1.0000 \mathrm{E}+01 \\
1.0000 \mathrm{E}+01 \\
1.0000 \mathrm{E}+01 \\
1.0000 \mathrm{E}+01 \\
1.9400 \mathrm{E}+04 \\
1.0000 \mathrm{E}+01 \\
1.0000 \mathrm{E}+01 \\
1.0000 \mathrm{E}+01\end{array}$ & 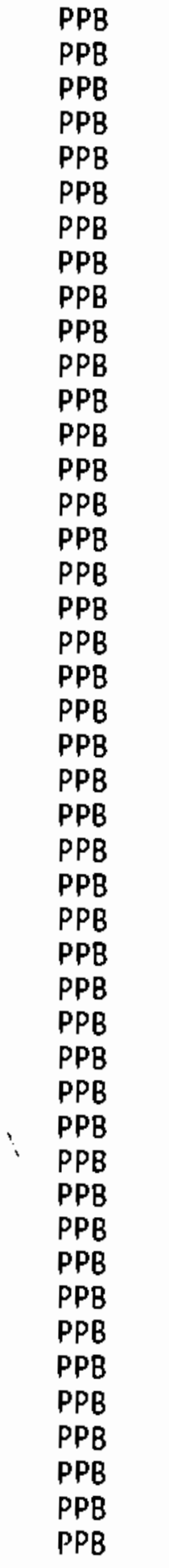 \\
\hline
\end{tabular}


TABLE B.2. (contd)

\begin{tabular}{|c|c|c|c|c|c|}
\hline $\begin{array}{l}\text { WELL } \\
\text { NAME }\end{array}$ & $\begin{array}{c}\text { COLLECTION } \\
\text { DATE }\end{array}$ & $\begin{array}{l}\text { CONST I TUENT } \\
\text { NAME }\end{array}$ & $\begin{array}{l}\text { LESS } \\
\text { THAN } \\
\text { FLAG }\end{array}$ & $\begin{array}{l}\text { ANALYSIS } \\
\text { VALUE }\end{array}$ & $\begin{array}{l}\text { ANALYSIS } \\
\text { UNITS }\end{array}$ \\
\hline $\begin{array}{l}2-E 34-1 \\
2-E 34-1 \\
2-E 34-1 \\
2-E 34-1 \\
2-E 34-1 \\
2-E 34-1 \\
2-E 34-1 \\
2-E 34-1 \\
2-E 34-1 \\
2-E 34-1 \\
2-E 34-1 \\
2-E 34-1 \\
2-E 34-1 \\
2-E 34-1 \\
2-E 34-1 \\
2-E 34-1 \\
2-E 34-1 \\
2-E 34-1 \\
2-E 34-1 \\
2-E 34-1 \\
2-E 34-1 \\
2-E 34-1 \\
2-E 34-1 \\
2-E 34-1 \\
2-E 34-1 \\
2-E 34-1 \\
2-E 34-1 \\
2-E 34-1 \\
2-E 34-1 \\
2-E 34-1 \\
2-E 34-1 \\
2-E 34-1 \\
2-E 34-1 \\
2-E 34-1 \\
2-E 34-1 \\
2-E 34-1 \\
2-E 34-1 \\
2-E 34-1 \\
2-E 34-1 \\
2-E 34-1 \\
2-E 34-1 \\
2-E 34-1 \\
2-E 34-1 \\
2-E 34-1 \\
2-E 34-1\end{array}$ & $\begin{array}{l}7 / 21 / 87 \\
7 / 21 / 87 \\
7 / 21 / 87 \\
7 / 21 / 87 \\
7 / 21 / 87 \\
7 / 21 / 87 \\
7 / 21 / 87 \\
7 / 21 / 87 \\
7 / 21 / 87 \\
7 / 21 / 87 \\
7 / 21 / 87 \\
7 / 21 / 87 \\
7 / 21 / 87 \\
7 / 21 / 87 \\
7 / 21 / 87 \\
7 / 21 / 87 \\
7 / 21 / 87 \\
7 / 21 / 87 \\
7 / 21 / 87 \\
7 / 21 / 87 \\
7 / 21 / 87 \\
7 / 21 / 87 \\
7 / 21 / 87 \\
8 / 13 / 87 \\
8 / 13 / 87 \\
8 / 13 / 87 \\
8 / 13 / 87 \\
8 / 13 / 87 \\
8 / 13 / 87 \\
9 / 15 / 87 \\
9 / 15 / 87 \\
9 / 15 / 87 \\
9 / 15 / 87 \\
9 / 15 / 87 \\
9 / 15 / 87 \\
10 / 07 / 87 \\
10 / 07 / 87 \\
10 / 07 / 87 \\
10 / 07 / 87 \\
10 / 07 / 87 \\
10 / 07 / 87 \\
11 / 10 / 87 \\
11 / 10 / 87 \\
11 / 10 / 87 \\
11 / 10 / 87\end{array}$ & $\begin{array}{l}\text { PENTCHB } \\
\text { PERCENE } \\
\text { PH-LAB } \\
\text { PHENOL } \\
\text { PHFIELD } \\
\text { PHOSPHA } \\
\text { PYRIDIN } \\
\text { RU-106 } \\
\text { SULFATE } \\
\text { TC } \\
\text { TETRANE } \\
\text { TETRCHB } \\
\text { TOC } \\
\text { TOLUENE } \\
\text { TOXLDL } \\
\text { TRANDCE } \\
\text { TRCMEOL } \\
\text { TRCMFLM } \\
\text { TRCPANE } \\
\text { TRICENE } \\
\text { TRICHLB } \\
\text { TRITIUM } \\
\text { VINYIDE } \\
\text { ALPHA } \\
\text { BETA } \\
\text { CO-60 } \\
\text { CS-137 } \\
\text { RU-106 } \\
\text { TRITIUM } \\
\text { ALPHA } \\
\text { BETA } \\
\text { CO-60 } \\
\text { CS-137 } \\
\text { RU-106 } \\
\text { TRITIUM } \\
\text { ALPHA } \\
\text { BETA } \\
\text { C0-60 } \\
\text { CS-I37 } \\
\text { RU-106 } \\
\text { TRITIUM } \\
\text { ALPHA } \\
\text { BETA } \\
\text { CO-60 } \\
\text { CS-I37 }\end{array}$ & $\begin{array}{l}< \\
< \\
< \\
< \\
< \\
< \\
< \\
< \\
< \\
< \\
< \\
< \\
<\end{array}$ & 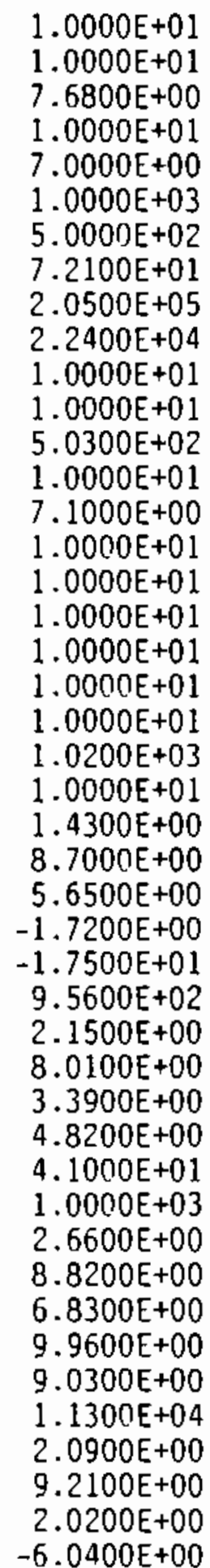 & $\begin{array}{l}\text { PPB } \\
P P B \\
\text { PPB } \\
\\
P P B \\
P P B \\
P C I / L \\
P P B \\
P P B \\
P P B \\
P P B \\
P P B \\
P P B \\
P P B \\
P P B \\
P P B \\
P P B \\
P P B \\
P P B \\
P P B \\
P C I / L \\
P P B \\
P C I / L \\
P C I / L \\
P C I / L \\
P C I / L \\
P C I / L \\
P C I / L \\
P C I / L \\
P C I / L \\
P C I / L \\
P C I / L \\
P C I / L \\
P C I / L \\
P C I / L \\
P C I / L \\
P C I / L \\
P C I / L \\
P C I / L \\
P C I / L \\
P C I / L \\
P C I / L \\
P C I / L \\
P C I / L\end{array}$ \\
\hline
\end{tabular}


TABLE B.2. (contd)

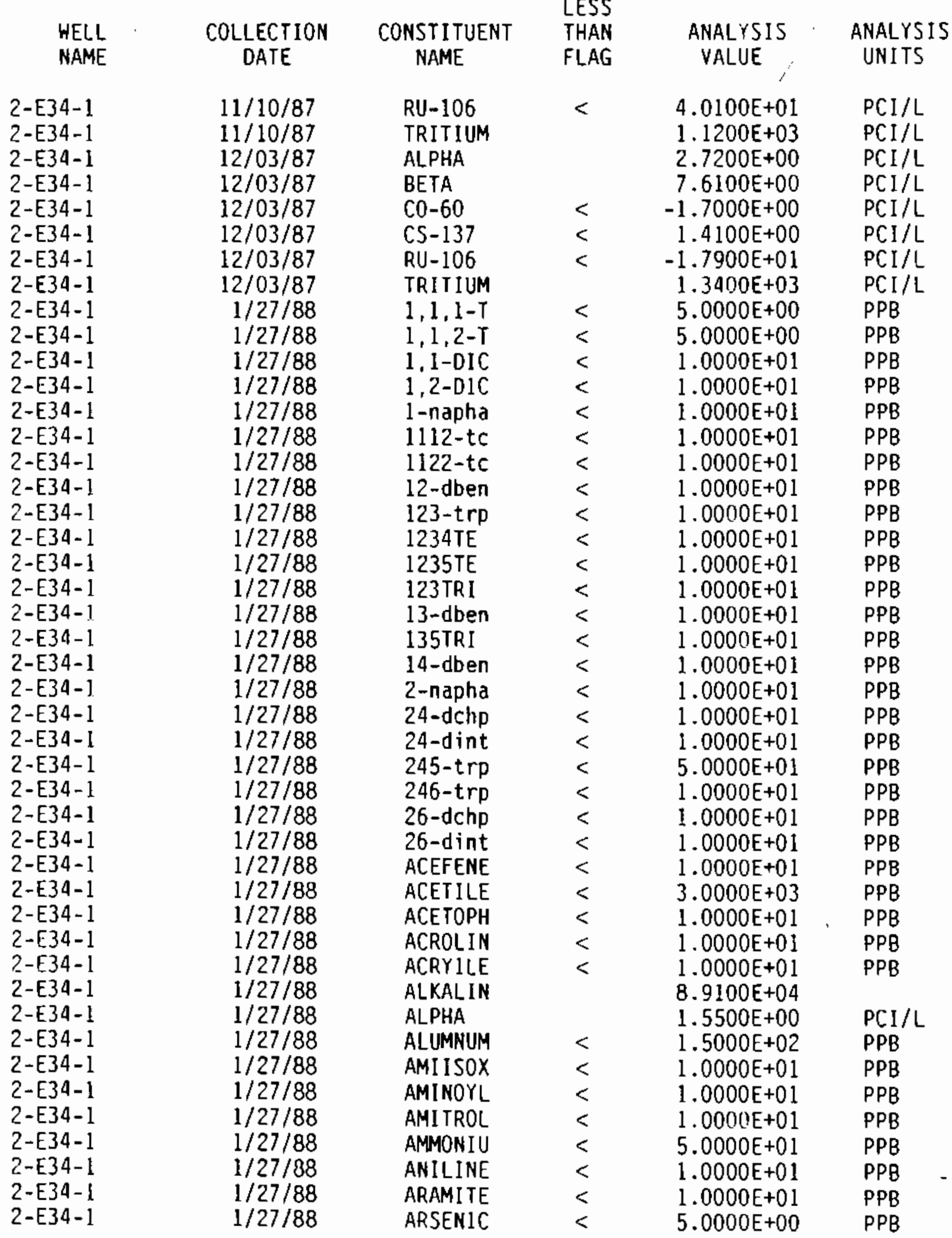


TABLE B.2. (contd)

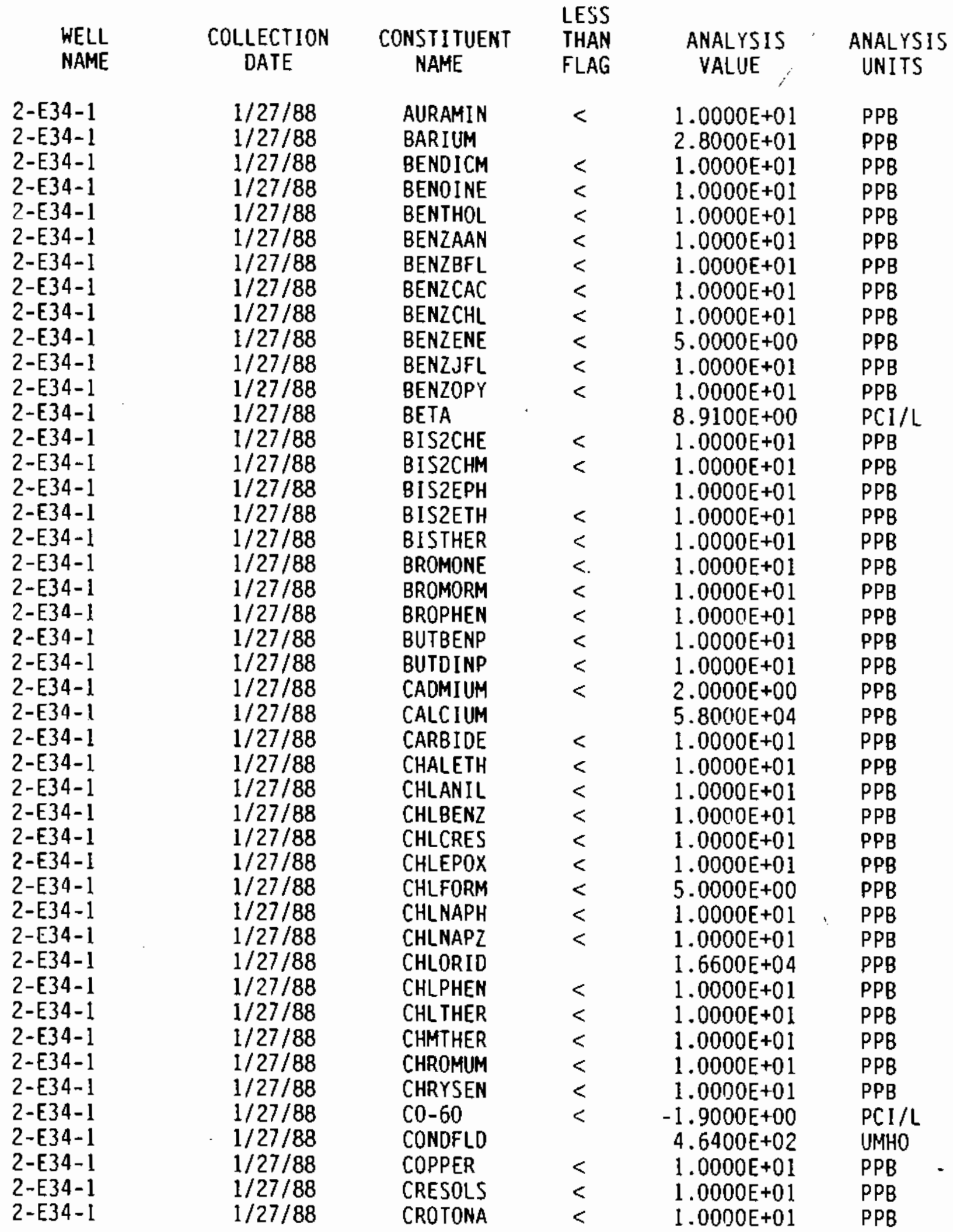


TABLE B.2. (contd)

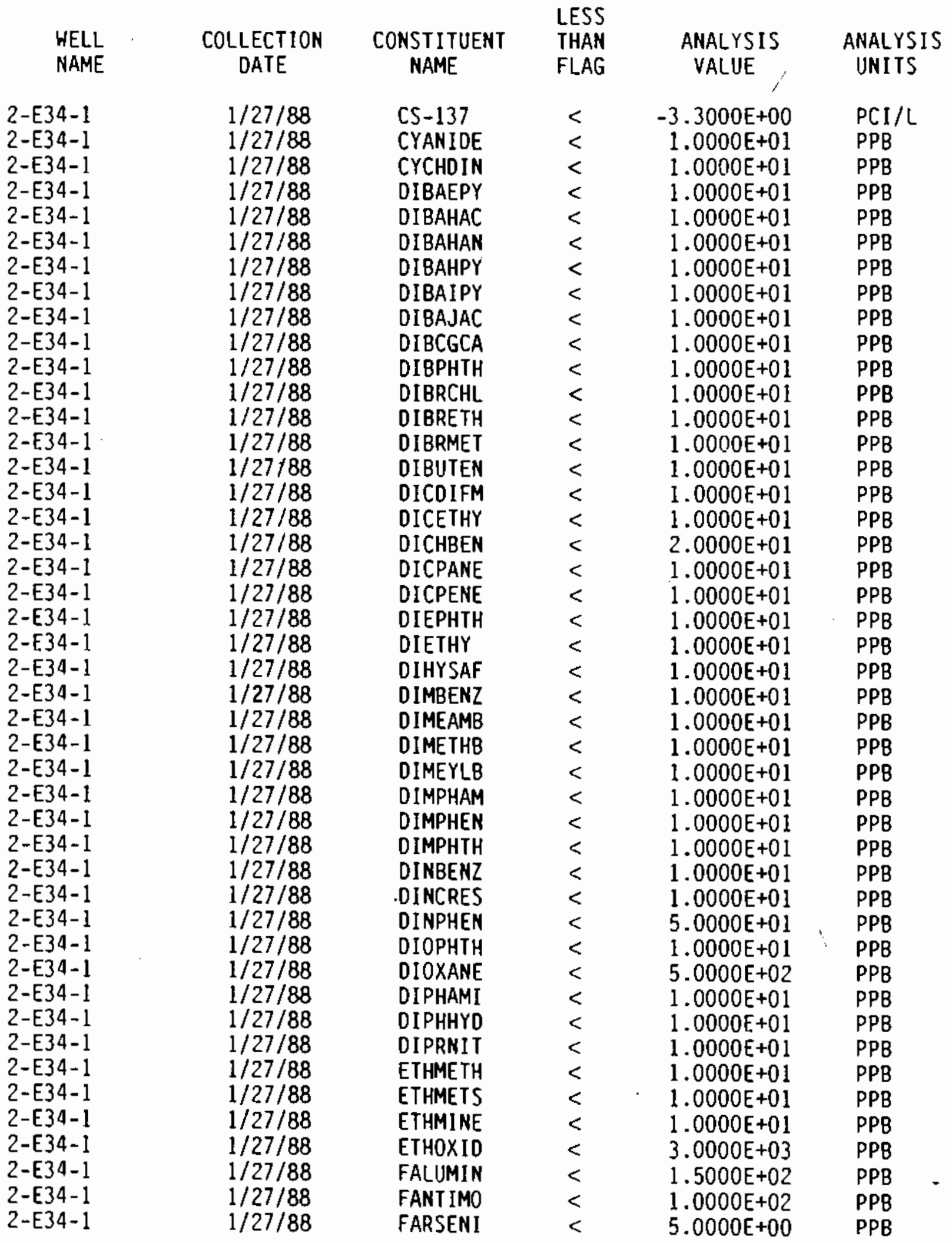


TABLE B.2. (contd)

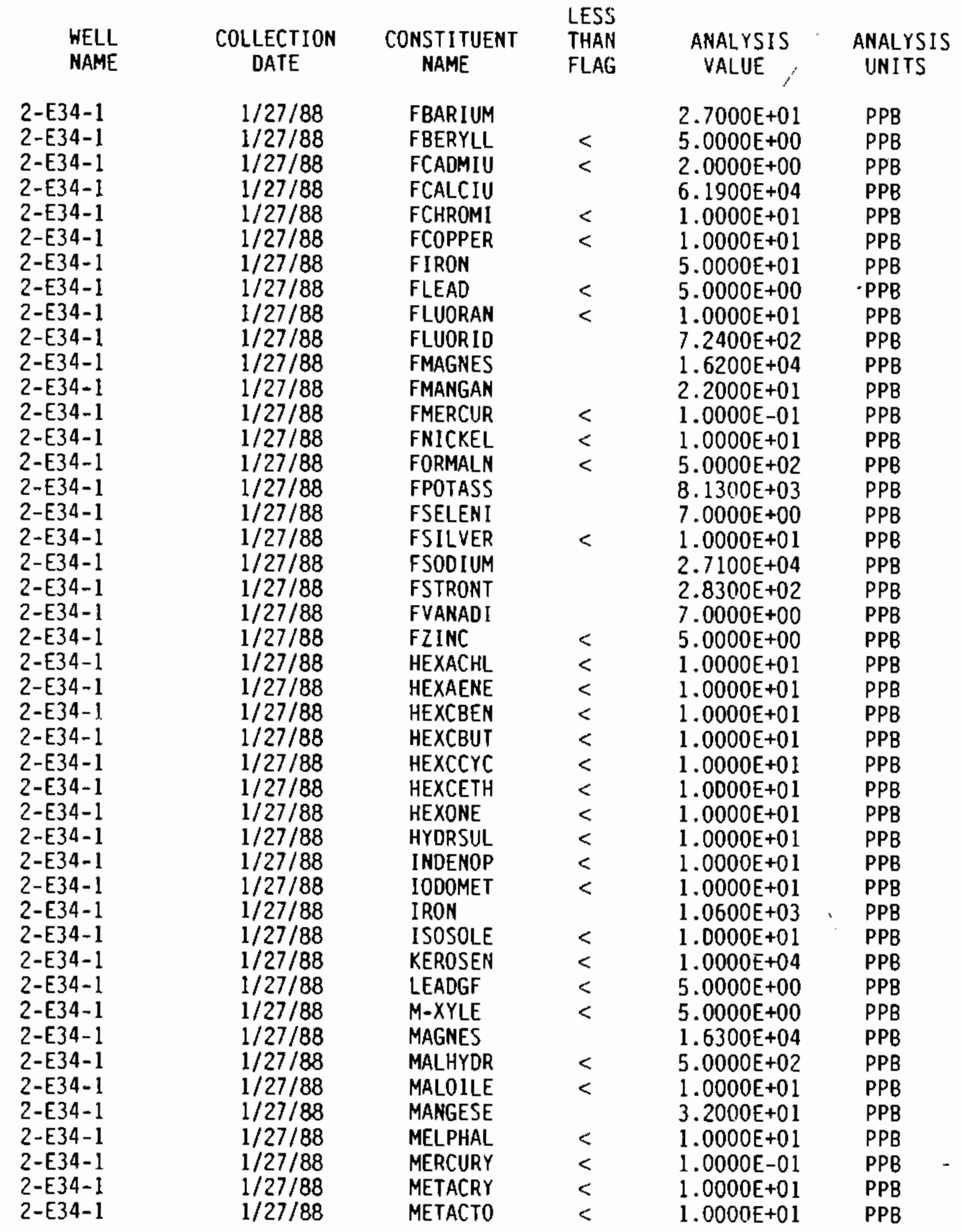


TABLE B.2. (contd)

\begin{tabular}{|c|c|c|c|c|c|}
\hline $\begin{array}{l}\text { WELL } \\
\text { NAME }\end{array}$ & $\begin{array}{l}\text { COLLECTION } \\
\text { DATE }\end{array}$ & $\begin{array}{l}\text { CONST I TUENT } \\
\text { NAME }\end{array}$ & $\begin{array}{l}\text { LESS } \\
\text { THAN } \\
\text { FLAG }\end{array}$ & $\begin{array}{l}\text { ANALYSIS } \\
\text { VALUE }\end{array}$ & $\begin{array}{l}\text { ANALYSIS } \\
\text { UNITS }\end{array}$ \\
\hline $2-E 34-1$ & $1 / 27 / 88$ & METAZIR & $<$ & $1.0000 E+01$ & PPB \\
\hline $2-E 34-1$ & $1 / 27 / 88$ & METBISC & $<$ & $1.0000 E+01$ & PPB \\
\hline $2-E 34-1$ & $1 / 27 / 88$ & METCHAN & $<$ & $1.0000 \mathrm{E}+01$ & PPB \\
\hline $2-E 34-1$ & $1 / 27 / 88$ & METHACR & $<$ & $1.0000 E+01$ & PPB \\
\hline 2-E34-1 & $1 / 27 / 88$ & METHAPY & $<$ & $1.0000 \mathrm{E}+01$ & PPB \\
\hline $2-E 34-1$ & $1 / 27 / 88$ & METHBRO & $<$ & $1.0000 \mathrm{E}+01$ & PPB \\
\hline $2-E 34-1$ & $1 / 27 / 88$ & METHCHL & $<$ & $1.0000 \mathrm{E}+01$ & PPB \\
\hline $2-E 34-1$ & $1 / 27 / 88$ & METHIOU & $<$ & $1.0000 \mathrm{E}+01$ & PPB \\
\hline $2-E 34-1$ & $1 / 27 / 88$ & METHNYL & $<$ & $1.0000 E+01$ & PPB \\
\hline $2-E 34-1$ & $1 / 27 / 88$ & METHONE & $<$ & $1.0000 E+01$ & PPB \\
\hline $2-E 34-1$ & $1 / 27 / 88$ & METHTHI & $<$ & $1.0000 E+01$ & PPB \\
\hline $2-E 34-1$ & $1 / 27 / 88$ & METHYCH & $<$ & $1.0000 E+01$ & PPB \\
\hline $2-E 34-1$ & $1 / 27 / 88$ & METMSUL & $<$ & $1.0000 E+01$ & PPB \\
\hline $2-E 34-1$ & $1 / 27 / 88$ & METPROP & $<$ & $1.0000 E+01$ & PPB \\
\hline $2-E 34-1$ & $1 / 27 / 88$ & NAPHQUI & $<$ & $1.0000 \mathrm{E}+01$ & PPB \\
\hline $2-E 34-1$ & $1 / 27 / 88$ & NAPHTHA & $<$ & $1.0000 \mathrm{E}+01$ & PPB \\
\hline $2-E 34-1$ & $1 / 27 / 88$ & NICKEL & $<$ & $1.0000 \mathrm{E}+01$ & PPB \\
\hline $2-E 34-1$ & $1 / 27 / 88$ & NICOTIN & $<$ & $1.0000 \mathrm{E}+02$ & PPB \\
\hline $2-E 34-1$ & $1 / 27 / 88$ & NI TBENZ & $<$ & $1.0000 \mathrm{E}+01$ & PPB \\
\hline $2-E 34-1$ & $1 / 27 / 88$ & NITPHEN & $<$ & $5.0000 E+01$ & PPB \\
\hline $2-E 34-1$ & $1 / 27 / 88$ & NITRANI & $<$ & $5.0000 E+01$ & PPB \\
\hline $2-E 34-1$ & $1 / 27 / 88$ & NITRATE & & $1.3400 E+04$ & PPB \\
\hline $2-E 34-1$ & $1 / 27 / 88$ & NITRPYR & $<$ & $1.0000 \mathrm{E}+0 \mathrm{i}$ & PPB \\
\hline $2-E 34-1$ & $1 / 27 / 88$ & NITRTOL & $<$ & $1.0000 E+01$ & PPB \\
\hline $2-E 34-1$ & $1 / 27 / 88$ & NNDIEHY & $<$ & $1.0000 E+01$ & PPB \\
\hline $2-E 34-1$ & $1 / 27 / 88$ & NNIBUTY & $<$ & $1.0000 \mathrm{E}+01$ & PPB \\
\hline $2-E 34-1$ & $1 / 27 / 88$ & NNIOIEA & $<$ & $1.0000 \mathrm{E}+01$ & PPB \\
\hline 2-E34-1 & $1 / 27 / 88$ & NNIDIEY & $<$ & $1.0000 \mathrm{E}+01$ & PPB \\
\hline $2-E 34-1$ & $1 / 27 / 88$ & NNIDIME & $<$ & $1.0000 E+01$ & PPB \\
\hline $2-E 34-1$ & $1 / 27 / 88$ & NNIMETH & $<$ & $1.0000 \mathrm{E}+01$ & PPB \\
\hline $2-E 34-1$ & $1 / 27 / 88$ & NN IMORP & $<$ & $1.0000 \mathrm{E}+\mathrm{D} 1$ & PPB \\
\hline $2-E 34-1$ & $1 / 27 / 88$ & NNINICO & $<$ & $1.0000 E+01$ & PPB \\
\hline $2-E 34-1$ & $1 / 27 / 88$ & NN IPIPE & $<$ & $1.0000 E+01$ & PPB \\
\hline $2-E 34-1$ & $1 / 27 / 88$ & NNIURET & $<$ & $1.0000 \mathrm{E}+01$ & PPB \\
\hline $2-E 34-1$ & $1 / 27 / 88$ & NNIVINY & $<$ & $1.0000 E+01$ & PPB \\
\hline 2-E34-1 & $1 / 27 / 88$ & OPXYLE & $<$ & $5.0000 E+00$ & PPB \\
\hline $4-1$ & $1 / 27 / 88$ & OTOLHYO & $<$ & $1.0000 \mathrm{E}+01$ & PPB \\
\hline & $1 / 27 / 88$ & PBENZQU & $<$ & $1.0000 \mathrm{E}+01$ & PPB \\
\hline & $1 / 27 / 88$ & PENTACH & $<$ & $1.0000 E+01$ & PPB \\
\hline-1 & $1 / 27 / 88$ & PENTCHB & $<$ & $1.0000 \mathrm{E}+01$ & PPB \\
\hline $1-1$ & $1 / 27 / 88$ & PENTCHN & $<$ & $1.0000 E+01$ & PPB \\
\hline $4-1$ & $1 / 27 / 88$ & PENTCHP & $<$ & $5.0000 E+01$ & PPB \\
\hline $1-1$ & $1 / 27 / 88$ & PERCENE & $<$ & $5.0000 E+00$ & PPB \\
\hline & $1 / 27 / 88$ & PH-LAB & & $7.7000 \mathrm{E}+00$ & \\
\hline & $1 / 27 / 88$ & PHENINE & $<$ & $1.0000 E+01$ & PPB \\
\hline
\end{tabular}


IABLE B.2. (contd)

\begin{tabular}{|c|c|c|c|c|c|}
\hline $\begin{array}{l}\text { WELL } \\
\text { NAME }\end{array}$ & $\begin{array}{c}\text { COLLECTION } \\
\text { OATE }\end{array}$ & $\begin{array}{l}\text { CONST ITUENT } \\
\text { NAME }\end{array}$ & $\begin{array}{l}\text { LESS } \\
\text { THAN } \\
\text { FLAG }\end{array}$ & $\begin{array}{l}\text { ANALYSIS } \\
\text { VALUE }\end{array}$ & $\begin{array}{l}\text { ANALYSIS } \\
\text { UNITS }\end{array}$ \\
\hline $\begin{array}{l}2-E 34-1 \\
2-E 34-1 \\
2-E 34-1 \\
2-E 34-1 \\
2-E 34-1 \\
2-E 34-1 \\
2-E 34-1 \\
2-E 34-1 \\
2-E 34-1 \\
2-E 34-1 \\
2-E 34-1 \\
2-E 34-1 \\
2-E 34-1 \\
2-E 34-1 \\
2-E 34-1 \\
2-E 34-1 \\
2-E 34-1 \\
2-E 34-1 \\
2-E 34-1 \\
2-E 34-1 \\
2-E 34-1 \\
2-E 34-1 \\
2-E 34-1 \\
2-E 34-1 \\
2-E 34-1 \\
2-E 34-1 \\
2-E 34-1 \\
2-E 34-1 \\
2-E 34-1 \\
2-E 34-1 \\
2-E 34-1 \\
2-E 34-1 \\
2-E 34-1 \\
2-E 34-1 \\
2-E 34-1 \\
2-E 34-1 \\
2-E 34-1 \\
2-E 34-1 \\
2-E 34-1 \\
2-E 34-1 \\
2-E 34-1 \\
2-E 34-1 \\
2-E 34-1 \\
2-E 34-1 \\
2-E 34-1\end{array}$ & $\begin{array}{l}1 / 27 / 88 \\
1 / 27 / 88 \\
1 / 27 / 88 \\
1 / 27 / 88 \\
1 / 27 / 88 \\
1 / 27 / 88 \\
1 / 27 / 88 \\
1 / 27 / 88 \\
1 / 27 / 88 \\
1 / 27 / 88 \\
1 / 27 / 88 \\
1 / 27 / 88 \\
1 / 27 / 88 \\
1 / 27 / 88 \\
1 / 27 / 88 \\
1 / 27 / 88 \\
1 / 27 / 88 \\
1 / 27 / 88 \\
1 / 27 / 88 \\
1 / 27 / 88 \\
1 / 27 / 88 \\
1 / 27 / 88 \\
1 / 27 / 88 \\
1 / 27 / 88 \\
1 / 27 / 88 \\
1 / 27 / 88 \\
1 / 27 / 88 \\
1 / 27 / 88 \\
1 / 27 / 88 \\
1 / 27 / 88 \\
1 / 27 / 88 \\
1 / 27 / 88 \\
1 / 27 / 88 \\
1 / 27 / 88 \\
1 / 27 / 88 \\
1 / 27 / 88 \\
1 / 27 / 88 \\
1 / 27 / 88 \\
1 / 27 / 88 \\
1 / 27 / 88 \\
1 / 27 / 88 \\
1 / 27 / 88 \\
1 / 27 / 88 \\
1 / 27 / 88 \\
6 / 03 / 88\end{array}$ & $\begin{array}{l}\text { PHENOL } \\
\text { PHENTIN } \\
\text { PHFIELO } \\
\text { PHOSPHA } \\
\text { PHTHEST } \\
\text { PICOLIN } \\
\text { POTASUM } \\
\text { PRONIOE } \\
\text { PYRIOIN } \\
\text { RADIUM } \\
\text { RESERPI } \\
\text { RESORCI } \\
\text { RU-IO6 } \\
\text { SAFROL } \\
\text { SELENUM } \\
\text { SILVER } \\
\text { SOOIUM } \\
\text { STRYCHN } \\
\text { SULFATE } \\
\text { SYMTRIN } \\
\text { TC } \\
\text { TETRANE } \\
\text { TETRCHB } \\
\text { TETRCHP } \\
\text { THIONOX } \\
\text { THIURAM } \\
\text { TOC } \\
\text { TOLUDIA } \\
\text { TOLUENE } \\
\text { TOXLOL } \\
\text { TRANDCE } \\
\text { TRCMEOL } \\
\text { TRCMFLM } \\
\text { TRCPANE } \\
\text { TRIBUPH } \\
\text { TRICENE } \\
\text { TRICHLB } \\
\text { TRIPHOS } \\
\text { TRISPHO } \\
\text { TRITIUM } \\
\text { VANAOUM } \\
\text { VINYIDE } \\
\text { WARFRIN } \\
\text { ZINC } \\
\text { ALPHA }\end{array}$ & $\begin{array}{l}< \\
< \\
< \\
< \\
< \\
< \\
< \\
< \\
< \\
< \\
< \\
< \\
< \\
< \\
< \\
< \\
< \\
< \\
< \\
< \\
< \\
< \\
< \\
< \\
< \\
< \\
< \\
< \\
< \\
< \\
< \\
< \\
< \\
< \\
< \\
< \\
<\end{array}$ & $\begin{array}{l}1.0000 \mathrm{E}+01 \\
1.0000 \mathrm{E}+01 \\
7.6000 \mathrm{E}+00 \\
1.0000 \mathrm{E}+03 \\
1.0000 \mathrm{E}+01 \\
1.0000 \mathrm{E}+01 \\
8.8000 \mathrm{E}+03 \\
1.0000 \mathrm{E}+01 \\
5.0000 \mathrm{E}+02 \\
1.6400 \mathrm{E}-01 \\
1.0000 \mathrm{E}+01 \\
1.0000 \mathrm{E}+01 \\
3.7000 \mathrm{E}+01 \\
1.0000 \mathrm{E}+01 \\
5.0000 \mathrm{E}+00 \\
1.0000 \mathrm{E}+01 \\
3.0300 \mathrm{E}+04 \\
5.0000 \mathrm{E}+01 \\
1.5300 \mathrm{E}+05 \\
1.0000 \mathrm{E}+01 \\
2.3000 \mathrm{E}+04 \\
5.0000 \mathrm{E}+00 \\
1.0000 \mathrm{E}+01 \\
1.0000 \mathrm{E}+01 \\
1.0000 \mathrm{E}+01 \\
1.0000 \mathrm{E}+01 \\
4.2100 \mathrm{E}+02 \\
1.0000 \mathrm{E}+01 \\
5.0000 \mathrm{E}+00 \\
2.6500 \mathrm{E}+01 \\
1.0000 \mathrm{E}+01 \\
1.0000 \mathrm{E}+01 \\
1.0000 \mathrm{E}+01 \\
1.0000 \mathrm{E}+01 \\
1.0000 \mathrm{E}+01 \\
5.0000 \mathrm{E}+00 \\
1.0000 \mathrm{E}+01 \\
1.0000 \mathrm{E}+01 \\
1.0000 \mathrm{E}+01 \\
1.4600 \mathrm{E}+03 \\
9.0000 \mathrm{E}+00 \\
1.0000 \mathrm{E}+01 \\
1.0000 \mathrm{E}+01 \\
5.0000 \mathrm{E}+00 \\
1.8700 \mathrm{E}+00\end{array}$ & 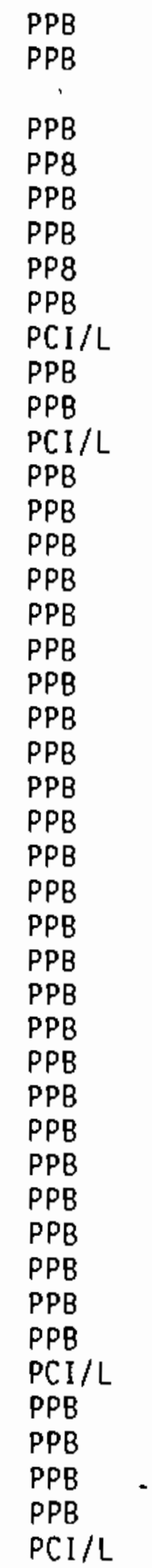 \\
\hline
\end{tabular}


IABLE B.2. (contd)

\begin{tabular}{|c|c|c|c|c|c|}
\hline $\begin{array}{l}\text { HELL } \\
\text { NAME }\end{array}$ & $\begin{array}{c}\text { COLLECTION } \\
\text { DATE }\end{array}$ & $\begin{array}{l}\text { CONSTI ITUENT } \\
\text { NAME }\end{array}$ & $\begin{array}{l}\text { LESS } \\
\text { THAN } \\
\text { FLAG }\end{array}$ & $\begin{array}{l}\text { ANALYSIS } \\
\text { VALUE }\end{array}$ & $\begin{array}{c}\text { ANALYSIS } \\
\text { UNITS }\end{array}$ \\
\hline 2-E34-1 & $6 / 03 / 88$ & BETA & & $9.0500 E+00$ & PCI/L \\
\hline $2-E 34-1$ & $6 / 03 / 88$ & $C 0-60$ & $<$ & $-1.5200 E+00$ & $\mathrm{PCI} / \mathrm{L}$ \\
\hline $2-E 34-1$ & $6 / 03 / 88$ & CS -137 & $<$ & $2.4700 E+00$ & $\mathrm{PCI} / \mathrm{L}$ \\
\hline $2-E 34-1$ & $6 / 03 / 88$ & RU-106 & $<$ & $-1.8000 \mathrm{E}+01$ & PCI/L \\
\hline $2-E 34-1$ & $6 / 03 / 88$ & TRITIUM & & $1.5100 E+03$ & $\mathrm{PCI} / \mathrm{L}$ \\
\hline $2-E 34-1$ & $7 / 26 / 88$ & ALPHA & & $1.5500 \mathrm{E}+00$ & $\mathrm{PCI} / \mathrm{L}$ \\
\hline $2-E 34-1$ & $7 / 26 / 88$ & BETA & & $5.8900 \mathrm{E}+00$ & $\mathrm{PCI} / \mathrm{L}$ \\
\hline $2-E 34-1$ & $7 / 26 / 88$ & $\mathrm{CO}-60$ & $<$ & $-4.1300 E+00$ & $\mathrm{PCI} / \mathrm{L}$ \\
\hline $2-E 34-1$ & $7 / 26 / 88$ & CS-137 & $<$ & $-2.9800 E+00$ & $\mathrm{PCI} / \mathrm{L}$ \\
\hline $2-E 34-1$ & $7 / 26 / 88$ & RU-106 & $<$ & $3.1200 \mathrm{E}+00$ & $\mathrm{PCI} / \mathrm{L}$ \\
\hline $2-E 34-1$ & $7 / 26 / 88$ & TRITIUM & & $1.6900 \mathrm{E}+03$ & $\mathrm{PCI} / \mathrm{L}$ \\
\hline $2-E 34-1$ & $10 / 25 / 88$ & ALPHA & & $1.7600 \mathrm{E}+00$ & $\mathrm{PCI} / \mathrm{L}$ \\
\hline $2-E 34-1$ & $10 / 25 / 88$ & BETA & & $9.8300 \mathrm{E}+00$ & $\mathrm{PCI} / \mathrm{L}$ \\
\hline $2-E 34-1$ & $10 / 25 / 88$ & $\mathrm{Co}-60$ & $<$ & $-1.6300 \mathrm{E}+00$ & $\mathrm{PCI} / \mathrm{L}$ \\
\hline $2-E 34-1$ & $10 / 25 / 88$ & CS -137 & $<$ & $-8.8100 \mathrm{E}-01$ & $\mathrm{PCI} / \mathrm{L}$ \\
\hline $2-E 34-1$ & $10 / 25 / 88$ & RU-106 & $<$ & $1.3600 \mathrm{E}+01$ & $\mathrm{PCI} / \mathrm{L}$ \\
\hline $\begin{array}{l}2-E 34-1 \\
2-E 34-1\end{array}$ & $\begin{array}{l}10 / 25 / 88 \\
11 / 09 / 88\end{array}$ & TRITIUM & & $1.9000 E+03$ & $\mathrm{PCI} / \mathrm{L}$ \\
\hline $2-E 34-1$ & $11 / 09 / 88$ & AMMONIU & $<$ & $5.0000 \mathrm{E}+01$ & PPB \\
\hline $2-E 34-1$ & $11 / 09 / 88$ & CHLORID & & $1.3200 E+04$ & PPB \\
\hline $2-E 34-1$ & Il $/ 09 / 88$ & CONDFLO & & $4.4000 E+02$ & UMHO \\
\hline $2-E 34-1$ & $11 / 09 / 88$ & CYANIOE & $<$ & $1.0000 E+01$ & PPB \\
\hline $2-E 34-1$ & $11 / 09 / 88$ & FLUORIO & $<$ & $5.0000 E+02$ & PPB \\
\hline $2-E 34-1$ & $11 / 09 / 88$ & NITRATE & & $1.2000 E+04$ & $\mathrm{PPB}$ \\
\hline $2-E 34-1$ & $11 / 09 / 88$ & PH-LAB & & $7.7000 \mathrm{E}+00$ & \\
\hline $2-E 34-1$ & $11 / 09 / 88$ & PHFIELD & & $7.9000 E+00$ & \\
\hline $2-E 34-1$ & $11 / 09 / 88$ & PHOSPHA & $<$ & $1.0000 E+03$ & PPB \\
\hline $2-E 34-1$ & $11 / 09 / 88$ & SULFATE & & $1.1100 E+05$ & PPB \\
\hline $2-E 34-1$ & $11 / 09 / 88$ & TOC & $<$ & $5.0000 \mathrm{E}+02$ & PPB \\
\hline $2-E 34-2$ & $9 / 23788$ & $1,1,1-T$ & $<$ & $5.0000 E+00$ & PPB \\
\hline $2-E 34-2$ & $9 / 23 / 88$ & $1,1,2-T$ & $<$ & $5.0000 E+00$ & PPB \\
\hline $2-E 34-2$ & $9 / 23 / 88$ & $1,1-0$ IC & $<$ & $1.0000 \mathrm{E}+01$ & PPB \\
\hline $2-E 34-2$ & $9 / 23 / 88$ & $1,2-D I C$ & $<$ & $1.0000 E+01$ & PPB \\
\hline 2-E34-2 & $9 / 23 / 88$ & 1-napha & $<$ & $1.0000 E+01$ & PPB \\
\hline $2-E 34-2$ & $9 / 23 / 88$ & $1112-t c$ & $<$ & $1.0000 \mathrm{E}+01$ & PPB \\
\hline $2-E 34-2$ & $9 / 23 / 88$ & $1122-t c$ & $<$ & $1.0000 \mathrm{E}+01$ & PPB \\
\hline $2-E 34-2$ & $9 / 23 / 88$ & 12 -dben & $<$ & $1.0000 \mathrm{E}+01$ & PPB \\
\hline $2-E 34-2$ & $9 / 23 / 88$ & $123-\operatorname{trp}$ & $<$ & $1.0000 \mathrm{E}+01$ & PPB \\
\hline $2-E 34-2$ & $9 / 23 / 88$ & $1234 \mathrm{TE}$ & $<$ & $1.0000 E+01$ & PPB \\
\hline $34-2$ & $9 / 23 / 88$ & $1235 \mathrm{TE}$ & $<$ & $1.0000 E+01$ & PPB \\
\hline $2-E 34-2$ & $9 / 23 / 88$ & 123TRI & $<$ & $1.0000 E+01$ & PPB \\
\hline $2-E 34-2$ & $9 / 23 / 88$ & 13-dben & $<$ & $1.0000 E+01$ & PPB \\
\hline $2-E 34-2$ & $9 / 23 / 88$ & 135TRI & $<$ & $1.0000 E+01$ & PPB \\
\hline $2-E 34-2$ & $9 / 23 / 88$ & 14 -dben & $<$ & $1.0000 \mathrm{E}+01$ & PPB \\
\hline $2-E 34-2$ & $9 / 23 / 88$ & $2,4,5-\mathrm{T}$ & $<$ & $2.0000 E+00$ & PPB \\
\hline
\end{tabular}


IABLE B.2. (contd)

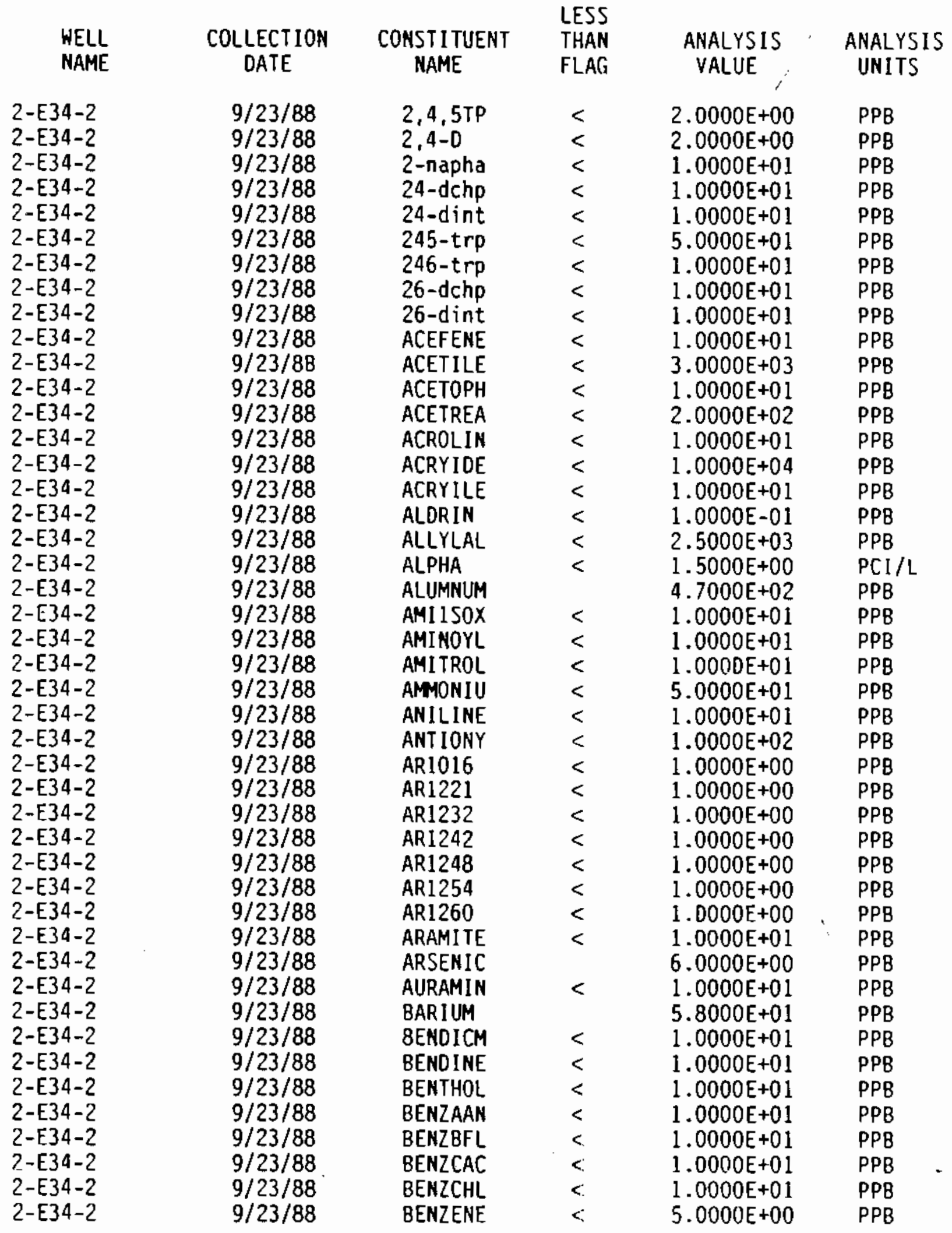


TABLE B.2. (contd)

\begin{tabular}{|c|c|c|c|c|c|}
\hline $\begin{array}{l}\text { WELL } \\
\text { NAME }\end{array}$ & $\begin{array}{l}\text { COLLECTION } \\
\text { DATE }\end{array}$ & $\begin{array}{l}\text { CONST ITUENT } \\
\text { NAME }\end{array}$ & $\begin{array}{l}\text { LESS } \\
\text { THAN } \\
\text { FLAG }\end{array}$ & $\begin{array}{l}\text { ANALYSIS } \\
\text { VALUE }\end{array}$ & $\begin{array}{l}\text { ANALYSIS } \\
\text { UNITS }\end{array}$ \\
\hline $\begin{array}{l}2-E 34-2 \\
2-E 34-2 \\
2-E 34-2 \\
2-E 34-2 \\
2-E 34-2 \\
2-E 34-2 \\
2-E 34-2 \\
2-E 34-2 \\
2-E 34-2 \\
2-E 34-2 \\
2-E 34-2 \\
2-E 34-2 \\
2-E 34-2 \\
2-E 34-2 \\
2-E 34-2 \\
2-E 34-2 \\
2-E 34-2 \\
2-E 34-2 \\
2-E 34-2 \\
2-E 34-2 \\
2-E 34-2 \\
2-E 34-2 \\
2-E 34-2 \\
2-E 34-2 \\
2-E 34-2 \\
2-E 34-2 \\
2-E 34-2 \\
2-E 34-2 \\
2-E 34-2 \\
2-E 34-2 \\
2-E 34-2 \\
2-E 34-2 \\
2-E 34-2 \\
2-E 34-2 \\
2-E 34-2 \\
2-E 34-2 \\
2-E 34-2 \\
2-E 34-2 \\
2-E 34-2 \\
2-E 34-2 \\
2-E 34-2 \\
2-E 34-2 \\
2-E 34-2 \\
2-E 34-2 \\
2-E 34-2\end{array}$ & $\begin{array}{l}9 / 23 / 88 \\
9 / 23 / 88 \\
9 / 23 / 88 \\
9 / 23 / 88 \\
9 / 23 / 88 \\
9 / 23 / 88 \\
9 / 23 / 88 \\
9 / 23 / 88 \\
9 / 23 / 88 \\
9 / 23 / 88 \\
9 / 23 / 88 \\
9 / 23 / 88 \\
9 / 23 / 88 \\
9 / 23 / 88 \\
9 / 23 / 88 \\
9 / 23 / 88 \\
9 / 23 / 88 \\
9 / 23 / 88 \\
9 / 23 / 88 \\
9 / 23 / 88 \\
9 / 23 / 88 \\
9 / 23 / 88 \\
9 / 23 / 88 \\
9 / 23 / 88 \\
9 / 23 / 88 \\
9 / 23 / 88 \\
9 / 23 / 88 \\
9 / 23 / 88 \\
9 / 23 / 88 \\
9 / 23 / 88 \\
9 / 23 / 88 \\
9 / 23 / 88 \\
9 / 23 / 88 \\
9 / 23 / 88 \\
9 / 23 / 88 \\
9 / 23 / 88 \\
9 / 23 / 88 \\
9 / 23 / 88 \\
9 / 23 / 88 \\
9 / 23 / 88 \\
9 / 23 / 88 \\
9 / 23 / 88 \\
9 / 23 / 88 \\
9 / 23 / 88 \\
9 / 23 / 88\end{array}$ & $\begin{array}{l}\text { BENZJFL } \\
\text { BENZOPY } \\
\text { BERYLUM } \\
\text { BETA } \\
\text { BIS2CHE } \\
\text { BIS2CHM } \\
\text { BIS2EPH } \\
\text { BIS2ETH } \\
\text { BISTHER } \\
\text { BROMONE } \\
\text { BROMORM } \\
\text { BROPHEN } \\
\text { BUTBENP } \\
\text { BUTDINP } \\
\text { CADMIUM } \\
\text { CALCIUM } \\
\text { CARBIOE } \\
\text { CARBPHT } \\
\text { CHALETH } \\
\text { CHLACET } \\
\text { CHLANIL } \\
\text { CHLBENZ } \\
\text { CHLCRES } \\
\text { CHLEPOX } \\
\text { CHLFORM } \\
\text { CHLLATE } \\
\text { CHLNAPH } \\
\text { CHLNAPZ } \\
\text { CHLOANE } \\
\text { CHLOREA } \\
\text { CHLORID } \\
\text { CHLPHEN } \\
\text { CHLPROP } \\
\text { CHLTHER } \\
\text { CHMTHER } \\
\text { CHROMUM } \\
\text { CHRYSEN } \\
\text { CITRUSR } \\
\text { CO-60 } \\
\text { COLIFRM } \\
\text { CONDFLD } \\
\text { CONDLAB } \\
\text { CONDLAB } \\
\text { CONOLAB } \\
\text { CONDLAB }\end{array}$ & $\begin{array}{l}< \\
< \\
< \\
< \\
< \\
< \\
< \\
< \\
< \\
< \\
< \\
< \\
< \\
< \\
< \\
< \\
< \\
< \\
< \\
< \\
< \\
< \\
< \\
< \\
< \\
< \\
< \\
< \\
< \\
< \\
< \\
< \\
< \\
< \\
<\end{array}$ & $\begin{array}{l}1.0000 E+01 \\
1.0000 E+01 \\
5.0000 E+00 \\
1.0600 E+01 \\
1.0000 E+01 \\
1.0000 E+01 \\
1.0000 E+01 \\
1.0000 E+01 \\
1.0000 E+01 \\
1.0000 E+01 \\
1.0000 E+01 \\
1.0000 E+01 \\
1.0000 E+01 \\
1.0000 E+01 \\
2.0000 E+00 \\
6.2300 E+04 \\
1.0000 E+01 \\
2.0000 E+00 \\
1.0000 E+01 \\
1.6000 E+04 \\
1.0000 E+01 \\
1.0000 E+01 \\
1.0000 E+01 \\
1.0000 E+01 \\
5.0000 E+00 \\
3.0000 E+01 \\
1.0000 E+01 \\
1.0000 E+01 \\
1.0000 E+00 \\
2.0000 E+02 \\
1.1400 E+04 \\
1.0000 E+01 \\
4.0000 E+03 \\
1.0000 E+01 \\
1.0000 E+01 \\
4.9000 E+01 \\
1.0000 E+01 \\
1.0000 E+03 \\
-3.9700 E+00 \\
2.2000 E+00 \\
4.3800 E+02 \\
5.5300 E+02 \\
5.5500 E+02 \\
5.5600 E+02 \\
5.5700 E+02\end{array}$ & 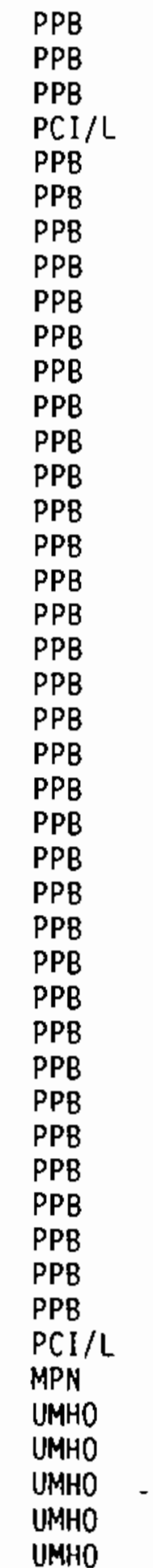 \\
\hline
\end{tabular}


TABLE B.2. (contd)

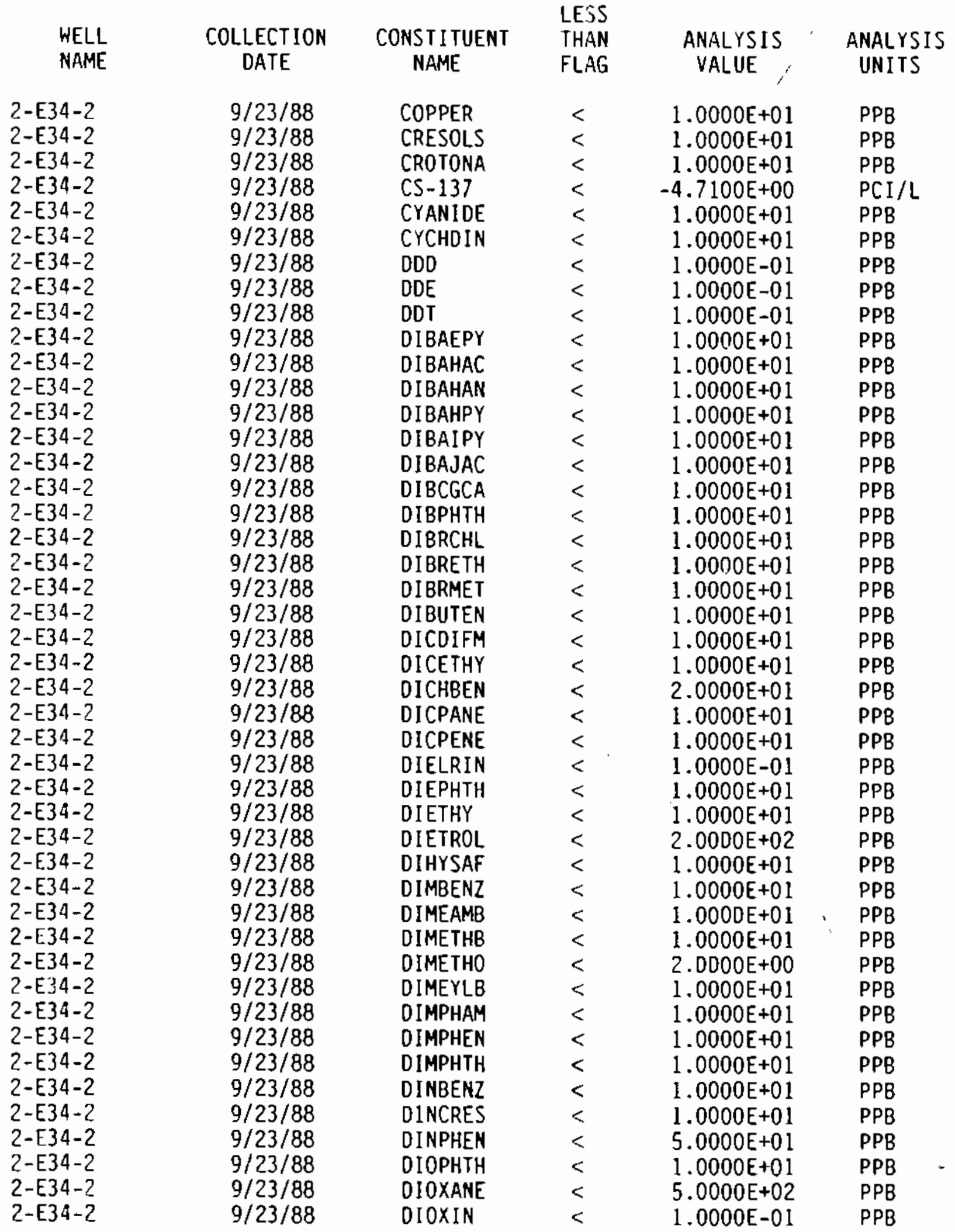


IABLE B.2. (contd)

\begin{tabular}{|c|c|c|c|c|c|}
\hline $\begin{array}{l}\text { WELL } \\
\text { NAME }\end{array}$ & $\begin{array}{c}\text { COLLECTION } \\
\text { DATE }\end{array}$ & $\begin{array}{l}\text { CONST I TUENT } \\
\text { NAME }\end{array}$ & $\begin{array}{l}\text { LESS } \\
\text { THAN } \\
\text { FLAG }\end{array}$ & $\begin{array}{l}\text { ANALYSIS } \\
\text { VALUE }\end{array}$ & $\begin{array}{l}\text { ANALYSIS } \\
\text { UNITS }\end{array}$ \\
\hline $2-E 34-2$ & $9 / 23 / 88$ & DIPHAMI & $<$ & $1.0000 E+01$ & PPB \\
\hline $2-E 34-2$ & $9 / 23 / 88$ & DIPHHYO & $<$ & $1.0000 \mathrm{E}+01$ & PPB \\
\hline $2-E 34-2$ & $9 / 23 / 88$ & DIPRNIT & $<$ & $1.0000 \mathrm{E}+01$ & PPB \\
\hline $2-E 34-2$ & $9 / 23 / 88$ & DISULFO & $<$ & $2.0000 \mathrm{E}+00$ & PPB \\
\hline $2-E 34-2$ & $9 / 23 / 88$ & ENDOI & $<$ & $1.0000 \mathrm{E}-01$ & $\mathrm{PPB}$ \\
\hline $2-E 34-2$ & $9 / 23 / 88$ & ENDO2 & $<$ & $1.0000 \mathrm{E}-01$ & PPB \\
\hline $2-E 34-2$ & $9 / 23 / 88$ & ENDRIN & $<$ & $1.0000 \mathrm{E}-01$ & PPB \\
\hline $2-E 34-2$ & $9 / 23 / 88$ & ETHCARB & $<$ & $5.0000 E+03$ & PPB \\
\hline $2-E 34-2$ & $9 / 23 / 88$ & ETHCYAN & $<$ & $2.0000 E+03$ & PPB \\
\hline $2-E 34-2$ & $9 / 23 / 88$ & ETHMETH & $<$ & $1.0000 E+01$ & PPB \\
\hline $2-E 34-2$ & $9 / 23 / 88$ & ETHMETS & $<$ & $1.0000 E+01$ & PPB \\
\hline $2-E 34-2$ & $9 / 23 / 88$ & ETHMINE & $<$ & $1.0000 E+01$ & PPB \\
\hline $2-E 34-2$ & $9 / 23 / 88$ & ETHOXID & $<$ & $3.0000 E+03$ & PPB \\
\hline $2-E 34-2$ & $9 / 23 / 88$ & ETHYGLY & $<$ & $1.0000 E+04$ & PPB \\
\hline $2-E 34-2$ & $9 / 23 / 88$ & ETHYREA & $<$ & $2.0000 \mathrm{E}+02$ & PPB \\
\hline $2-E 34-2$ & $9 / 23 / 88$ & FALUMIN & $<$ & $1.5000 E+02$ & PPB \\
\hline $2-E 34-2$ & $9 / 23 / 88$ & FANTIMO & $<$ & $1.0000 \mathrm{E}+02$ & PPB \\
\hline $2-E 34-2$ & $9 / 23 / 88$ & FARSENI & & $6.0000 E+00$ & PPB \\
\hline $2-E 34-2$ & $9 / 23 / 88$ & FBARIUM & & $4.1000 E+01$ & PPB \\
\hline $2-E 34-2$ & $9 / 23 / 88$ & FBERYLL & $<$ & $5.0000 E+00$ & PPB \\
\hline$\hat{c}-E 34-2$ & $9 / 23 / 88$ & FCAOMIU & $<$ & $2.0000 \mathrm{E}+00$ & PPB \\
\hline $2-E 31-2$ & $9 / 23 / 88$ & FCALCIU & & $5.6500 \mathrm{E}+04$ & PPB \\
\hline $2-E 34-2$ & $9 / 23 / 88$ & FCHROMI & $<$ & $1.0000 E+01$ & PPB \\
\hline $2-E 34-2$ & $9 / 23 / 88$ & FCOPPER & $<$ & $1.0000 E+01$ & PPB \\
\hline $2-E 34-2$ & $9 / 23 / 88$ & FIRON & $<$ & $3.0000 E+01$ & PPB \\
\hline $2-E 34-2$ & $9 / 23 / 88$ & FLEAD & $<$ & $5.0000 \mathrm{E}+00$ & PPB \\
\hline $2-E 34-2$ & $9 / 23 / 88$ & FLUORAN & $<$ & $1.0000 E+01$ & PPB \\
\hline $2-E 34-2$ & $9 / 23 / 88$ & FLUORID & $<$ & $5.0000 E+02$ & PPB \\
\hline $2-E 34-2$ & $9 / 23 / 88$ & FMAGNES & & $1.6000 E+04$ & PPB \\
\hline $2-E 34-2$ & $9 / 23 / 88$ & FMANGAN & $<$ & $5.0000 \mathrm{E}+00$ & PPB \\
\hline $2-E 34-2$ & $9 / 23 / 88$ & FMERCUR & $<$ & $1.0000 E-01$ & PPB \\
\hline $2-E 34-2$ & $9 / 23 / 88$ & FNICKEL & $<$ & $1.0000 \mathrm{E}+01$ & PPB \\
\hline $2-E 34-2$ & $9 / 23 / 88$ & FORMALN & $<$ & $5.0000 \mathrm{E}+02$ & PPB \\
\hline $2-E 34-2$ & $9 / 23 / 88$ & FPOTASS & & $8.1700 E+03$ & PPB \\
\hline $2-E 34-2$ & $9 / 23 / 88$ & FSELENI & & $8.0000 E+00$ & PPB \\
\hline $2-E 34-2$ & $9 / 23 / 88$ & FSILVER & $<$ & $1.0000 \mathrm{E}+01$ & PPB \\
\hline $2-E 34-2$ & $9 / 23 / 88$ & FSODIUM & & $3.1300 \mathrm{E}+04$ & PPB \\
\hline $2-E 34-2$ & $9 / 23 / 88$ & FSTRONT & & $2.6700 \mathrm{E}+02$ & PPB \\
\hline $4-2$ & $9 / 23 / 88$ & FTHALL 1 & $<$ & $5.0000 E+00$ & PPB \\
\hline $4-2$ & $9 / 23 / 88$ & FVANADI & & $2.2000 E+01$ & PPB \\
\hline $2-E 34-2$ & $9 / 23 / 88$ & FZINC & $<$ & $5.0000 E+00$ & PPB \\
\hline $34-2$ & $9 / 23 / 88$ & HEPTIDE & $<$ & $1.0000 \mathrm{E}-01$ & PPB \\
\hline $4-2$ & $9 / 23 / 88$ & HEPTLOR & $<$ & $1.0000 E-01$ & PPB \\
\hline $4-2$ & $9 / 23 / 88$ & HEXACHL & $<$ & $1.0000 \mathrm{E}+01$ & PPB \\
\hline $4-2$ & $9 / 23 / 88$ & HEXAENE & $<$ & $1.0000 E+01$ & PPB \\
\hline
\end{tabular}


IABLE B.2. (contd)

\begin{tabular}{|c|c|c|c|c|c|}
\hline $\begin{array}{l}\text { WELL } \\
\text { NAME }\end{array}$ & $\begin{array}{l}\text { COLLECTION } \\
\text { DATE }\end{array}$ & $\begin{array}{l}\text { CONSTITUENT } \\
\text { NAME }\end{array}$ & $\begin{array}{l}\text { LESS } \\
\text { THAN } \\
\text { FLAG }\end{array}$ & $\begin{array}{l}\text { ANALYSIS } \\
\text { VALUE }\end{array}$ & $\begin{array}{l}\text { ANALYSIS } \\
\text { UNITS }\end{array}$ \\
\hline $2-E 34-2$ & $9 / 23 / 88$ & HEXCBEN & $<$ & $1.0000 E+01$ & PPB \\
\hline $2-E 34-2$ & $9 / 23 / 88$ & HEXCBUT & $<$ & $1.0000 E+01$ & PPB \\
\hline $2-E 34-2$ & $9 / 23 / 88$ & HEXCCYC & $<$ & $1.0000 E+01$ & PPB \\
\hline $2-E 34-2$ & $9 / 23 / 88$ & HEXCETH & $<$ & $1.0000 E+01$ & PPB \\
\hline $2-E 34-2$ & $9 / 23 / 88$ & HEXONE & $<$ & $1.0000 E+01$ & PPB \\
\hline $2-E 34-2$ & $9 / 23 / 88$ & HYORAZ I & $<$ & $3.0000 \mathrm{E}+03$ & PPB \\
\hline $2-E 34-2$ & $9 / 23 / 88$ & HYORSUL & $<$ & $1.0000 E+01$ & PPB \\
\hline $2-E 34-2$ & $9 / 23 / 88$ & INDENOP & $<$ & $1.0000 E+01$ & PPB \\
\hline $2-E 34-2$ & $9 / 23 / 88$ & IODOHET & $<$ & $1.0000 E+01$ & PPB \\
\hline $2-E 34-2$ & $9 / 23 / 88$ & IRON & & $1.2500 E+03$ & PPB \\
\hline $2-E 34-2$ & $9 / 23 / 88$ & ISOBUTY & $<$ & $1.0000 E+03$ & PPB \\
\hline $2-E 34-2$ & $9 / 23 / 88$ & ISOSOLE & $<$ & $1.0000 E+01$ & PPB \\
\hline $2-E 34-2$ & $9 / 23 / 88$ & KEROSEN & $<$ & $1.0000 E+04$ & PPB \\
\hline $2-E 34-2$ & $9 / 23 / 88$ & LEADGF & $<$ & $5.0000 E+00$ & PPB \\
\hline $2-E 34-2$ & $9 / 23 / 88$ & M-XYLE & $<$ & $5.0000 E+00$ & PPB \\
\hline $2-E 34-2$ & $9 / 23 / 88$ & MAGNES & & $1.7100 E+04$ & PPB \\
\hline $2-E 34-2$ & $9 / 23 / 88$ & MALHYDR & $<$ & $5.0000 \mathrm{E}+02$ & PPB \\
\hline $2-E 34-2$ & $9 / 23 / 88$ & MALOILE & $<$ & $1.0000 E+01$ & PPB \\
\hline $2-E 34-2$ & $9 / 23 / 88$ & MANGESE & & $3.0000 \mathrm{E}+01$ & PPB \\
\hline $2-E 34-2$ & $9 / 23 / 88$ & MELPHAL & $<$ & $1.0000 E+01$ & PPB \\
\hline $2-E 34-2$ & $9 / 23 / 88$ & MERCURY & $<$ & $1.0000 E-01$ & PPB \\
\hline $2-E 34-2$ & $9 / 23 / 88$ & METACRY & $<$ & $1.0000 E+01$ & PPB \\
\hline $2-E 34-2$ & $9 / 23 / 88$ & METACTO & $<$ & $1.0000 E+01$ & PPB \\
\hline $2-E 34-2$ & $9 / 23 / 88$ & METAZ IR & $<$ & $1.0000 \mathrm{E}+01$ & PPB \\
\hline $2-E 34-2$ & $9 / 23 / 88$ & METBISC & $<$ & $1.0000 E+01$ & PPB \\
\hline $2-E 34-2$ & $9 / 23 / 88$ & METCHAN & $<$ & $1.0000 E+01$ & PPB \\
\hline $2-E 34-2$ & $9 / 23 / 88$ & METHACR & $<$ & $1.0000 E+01$ & PPB \\
\hline $2-E 34-2$ & $9 / 23 / 88$ & METHAPY & $<$ & $1.0000 E+01$ & PPB \\
\hline $2-E 34-2$ & $9 / 23 / 88$ & METHBRO & $<$ & $1.0000 E+01$ & PPB \\
\hline $2-E 34-2$ & $9 / 23 / 88$ & METHCHL & $<$ & $1.0000 \mathrm{E}+01$ & PPB \\
\hline $2-E 34-2$ & $9 / 23 / 88$ & METHIOU & $<$ & $1.0000 E+01$ & PPB \\
\hline $2-E 34-2$ & $9 / 23 / 88$ & METHLOR & $<$ & $3.0000 E+00$ & PPB \\
\hline $2-E 34-2$ & $9 / 23 / 88$ & METHNYL & $<$ & $1.0000 E+01$ & PPB \\
\hline $2-E 34-2$ & $9 / 23 / 88$ & METHONE & $<$ & $1.0000 E+01$ & PPB \\
\hline $2-E 34-2$ & $9 / 23 / 88$ & METHPAR & $<$ & $2.0000 E+00$ & PPB \\
\hline $4-2$ & $9 / 23 / 88$ & METHTHI & $<$ & $1.0000 E+01$ & PPB \\
\hline $4-2$ & $9 / 23 / 88$ & METHYCH & $<$ & $1.0000 E+01$ & PPB \\
\hline $34-2$ & $9 / 23 / 88$ & METMSUL & $<$ & 1. $D 000 E+01$ & PPB \\
\hline $4-2$ & $9 / 23 / 88$ & METPROP & $<$ & $1.0000 E+01$ & PPB \\
\hline $4-2$ & $9 / 23 / 88$ & NAPHQUI & $<$ & $1.0000 \mathrm{E}+01$ & PPB \\
\hline $4-2$ & $9 / 23 / 88$ & NAPHREA & $<$ & $2.0000 E+02$ & PPB \\
\hline $34-2$ & $9 / 23 / 88$ & NAPHTHA & $<$ & $1.0000 \mathrm{E}+01$ & PPB \\
\hline $34-2$ & $9 / 23 / 88$ & NICKEL & & $2.2000 \mathrm{E}+01$ & PPB \\
\hline $34-2$ & $9 / 23 / 88$ & NICOTIN & $<$ & $1.0000 E+02$ & PPB \\
\hline $34-2$ & $9 / 23 / 88$ & NITBENZ & $<$ & $1.0000 \mathrm{E}+01$ & PPB \\
\hline
\end{tabular}


TABLE B.2. (contd)

\begin{tabular}{|c|c|c|c|c|c|}
\hline $\begin{array}{l}\text { HELL } \\
\text { NAME }\end{array}$ & $\begin{array}{l}\text { COLLECTION } \\
\text { DATE }\end{array}$ & $\begin{array}{l}\text { CONST I TUENT } \\
\text { NAME }\end{array}$ & $\begin{array}{l}\text { LESS } \\
\text { THAN } \\
\text { FLAG }\end{array}$ & $\begin{array}{l}\text { ANALYSIS } \\
\text { VALUE }\end{array}$ & $\begin{array}{l}\text { ANALYSIS } \\
\text { UNITS }\end{array}$ \\
\hline $\begin{array}{l}2-E 34-2 \\
2-E 34-2 \\
2-E 34-2 \\
2-E 34-2 \\
2-E 34-2 \\
2-E 34-2 \\
2-E 34-2 \\
2-E 34-2 \\
2-E 34-2 \\
2-E 34-2 \\
2-E 34-2 \\
2-E 34-2 \\
2-E 34-2 \\
2-E 34-2 \\
2-E 34-2 \\
2-E 34-2 \\
2-E 34-2 \\
2-E 34-2 \\
2-E 34-2 \\
2-E 34-2 \\
2-E 34-2 \\
2-E 34-2 \\
2-E 34-2 \\
2-E 34-2 \\
2-E 34-2 \\
2-E 34-2 \\
2-E 34-2 \\
2-E 34-2 \\
2-E 34-2 \\
2-E 34-2 \\
2-E 34-2 \\
2-E 34-2 \\
2-E 34-2 \\
2-E 34-2 \\
2-E 34-2 \\
2-E 34-2 \\
2-E 34-2 \\
2-E 34-2 \\
2-E 34-2 \\
2-E 34-2 \\
2-E 34-2 \\
2-E 34-2 \\
2-E 34-2 \\
2-E 34-2 \\
2-E 34-2\end{array}$ & $\begin{array}{l}9 / 23 / 88 \\
9 / 23 / 88 \\
9 / 23 / 88 \\
9 / 23 / 88 \\
9 / 23 / 88 \\
9 / 23 / 88 \\
9 / 23 / 88 \\
9 / 23 / 88 \\
9 / 23 / 88 \\
9 / 23 / 88 \\
9 / 23 / 88 \\
9 / 23 / 88 \\
9 / 23 / 88 \\
9 / 23 / 88 \\
9 / 23 / 88 \\
9 / 23 / 88 \\
9 / 23 / 88 \\
9 / 23 / 88 \\
9 / 23 / 88 \\
9 / 23 / 88 \\
9 / 23 / 88 \\
9 / 23 / 88 \\
9 / 23 / 88 \\
9 / 23 / 88 \\
9 / 23 / 88 \\
9 / 23 / 88 \\
9 / 23 / 88 \\
9 / 23 / 88 \\
9 / 23 / 88 \\
9 / 23 / 88 \\
9 / 23 / 88 \\
9 / 23 / 88 \\
9 / 23 / 88 \\
9 / 23 / 88 \\
9 / 23 / 88 \\
9 / 23 / 88 \\
9 / 23 / 88 \\
9 / 23 / 88 \\
9 / 23 / 88 \\
9 / 23 / 88 \\
9 / 23 / 88 \\
9 / 23 / 88 \\
9 / 23 / 88 \\
9 / 23 / 88 \\
9 / 23 / 88\end{array}$ & $\begin{array}{l}\text { NITPHEN } \\
\text { NITRANI } \\
\text { NITRATE } \\
\text { NITRPYR } \\
\text { NITRTOL } \\
\text { NNDIEHY } \\
\text { NNIBUTY } \\
\text { NNIDIEA } \\
\text { NNIOIEY } \\
\text { NNIDIME } \\
\text { NNIMETH } \\
\text { NNIMORP } \\
\text { NNINICO } \\
\text { NNIPIPE } \\
\text { NNIURET } \\
\text { NNIVINY } \\
\text { OPXYLE } \\
\text { OTOLHYD } \\
\text { PARALDE } \\
\text { PARATHI } \\
\text { PBENZQU } \\
\text { PENTACH } \\
\text { PENTCHB } \\
\text { PENTCHN } \\
\text { PENTCHP } \\
\text { PERCENE } \\
\text { PERCHLO } \\
\text { PH-LAB } \\
\text { PH-LAB } \\
\text { PHENINE } \\
\text { PHENOL } \\
\text { PHENREA } \\
\text { PHENTIN } \\
\text { PHFIELD } \\
\text { PHOSPHA } \\
\text { PHTHEST } \\
\text { PICOLIN } \\
\text { POTASUM } \\
\text { PRONIDE } \\
\text { PROPYLA } \\
\text { PROPYNO } \\
\text { PYRIDIN } \\
\text { RADIUM } \\
\text { RESERPI } \\
\text { RESORCI }\end{array}$ & 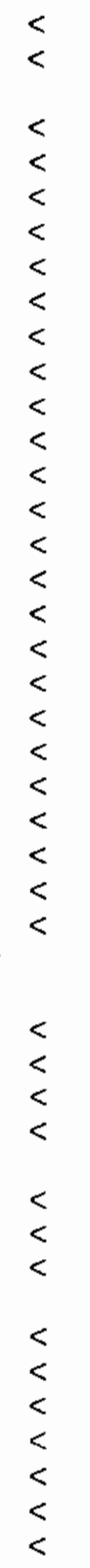 & $\begin{array}{l}5.0000 \mathrm{E}+01 \\
5.0000 \mathrm{E}+01 \\
1.1800 \mathrm{E}+04 \\
1.0000 \mathrm{E}+01 \\
1.0000 \mathrm{E}+01 \\
1.0000 \mathrm{E}+01 \\
1.0000 \mathrm{E}+01 \\
1.0000 \mathrm{E}+01 \\
1.0000 \mathrm{E}+01 \\
1.0000 \mathrm{E}+01 \\
1.0000 \mathrm{E}+01 \\
1.0000 \mathrm{E}+01 \\
1.0000 \mathrm{E}+01 \\
1.0000 \mathrm{E}+01 \\
1.0000 \mathrm{E}+01 \\
1.0000 \mathrm{E}+01 \\
5.0000 \mathrm{E}+00 \\
1.0000 \mathrm{E}+01 \\
2.0000 \mathrm{E}+03 \\
2.0000 \mathrm{E}+00 \\
1.0000 \mathrm{E}+01 \\
1.0000 \mathrm{E}+01 \\
1.0000 \mathrm{E}+01 \\
1.0000 \mathrm{E}+01 \\
5.0000 \mathrm{E}+01 \\
5.0000 \mathrm{E}+00 \\
1.0000 \mathrm{E}+03 \\
7.8000 \mathrm{E}+00 \\
7.9000 \mathrm{E}+00 \\
1.0000 \mathrm{E}+01 \\
1.0000 \mathrm{E}+01 \\
5.0000 \mathrm{E}+02 \\
1.0000 \mathrm{E}+01 \\
8.0000 \mathrm{E}+00 \\
1.0000 \mathrm{E}+03 \\
1.0000 \mathrm{E}+01 \\
1.0000 \mathrm{E}+01 \\
8.8600 \mathrm{E}+03 \\
1.0000 \mathrm{E}+01 \\
1.0000 \mathrm{E}+04 \\
8.0000 \mathrm{E}+03 \\
5.0000 \mathrm{E}+02 \\
1.3900 \mathrm{E}-01 \\
1.0000 \mathrm{E}+01 \\
1.0000 \mathrm{E}+01\end{array}$ & 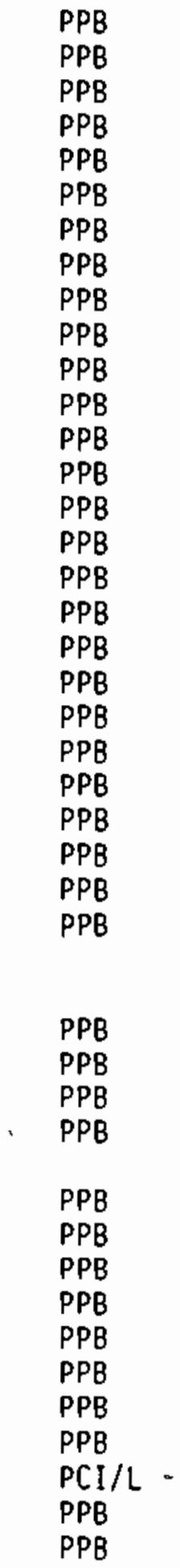 \\
\hline
\end{tabular}


TABLE B.2. (contd)

\begin{tabular}{|c|c|c|c|c|c|}
\hline $\begin{array}{l}\text { WELL } \\
\text { NAME }\end{array}$ & $\begin{array}{l}\text { COLLECTION } \\
\text { DATE }\end{array}$ & $\begin{array}{l}\text { CONST I TUENT } \\
\text { NAME }\end{array}$ & $\begin{array}{l}\text { LESS } \\
\text { THAN } \\
\text { FLAG }\end{array}$ & $\begin{array}{l}\text { ANALYSIS } \\
\text { VALUE }\end{array}$ & $\begin{array}{l}\text { ANALYSIS } \\
\text { UNITS }\end{array}$ \\
\hline $\begin{array}{l}2-E 34-2 \\
2-E 34-2 \\
2-E 34-2 \\
2-E 34-2 \\
2-E 34-2 \\
2-E 34-2 \\
2-E 34-2 \\
2-E 34-2 \\
2-E 34-2 \\
2-E 34-2 \\
2-E 34-2 \\
2-E 34-2 \\
2-E 34-2 \\
2-E 34-2 \\
2-E 34-2 \\
2-E 34-2 \\
2-E 34-2 \\
2-E 34-2 \\
2-E 34-2 \\
2-E 34-2 \\
2-E 34-2 \\
2-E 34-2 \\
2-E 34-2 \\
2-E 34-2 \\
2-E 34-2 \\
2-E 34-2 \\
2-E 34-2 \\
2-E 34-2 \\
2-E 34-2 \\
2-E 34-2 \\
2-E 34-2 \\
2-E 34-2 \\
2-E 34-2 \\
2-E 34-2 \\
2-E 34-2 \\
2-E 34-2 \\
2-E 34-2 \\
2-E 34-2 \\
2-E 34-2 \\
2-E 34-2 \\
2-E 34-2 \\
2-E 34-2 \\
2-E 34-2 \\
2-E 34-2 \\
2-E 34-2\end{array}$ & $\begin{array}{l}9 / 23 / 88 \\
9 / 23 / 88 \\
9 / 23 / 88 \\
9 / 23 / 88 \\
9 / 23 / 88 \\
9 / 23 / 88 \\
9 / 23 / 88 \\
9 / 23 / 88 \\
9 / 23 / 88 \\
9 / 23 / 88 \\
9 / 23 / 88 \\
9 / 23 / 88 \\
9 / 23 / 88 \\
9 / 23 / 88 \\
9 / 23 / 88 \\
9 / 23 / 88 \\
9 / 23 / 88 \\
9 / 23 / 88 \\
9 / 23 / 88 \\
9 / 23 / 88 \\
9 / 23 / 88 \\
9 / 23 / 88 \\
9 / 23 / 88 \\
9 / 23 / 88 \\
9 / 23 / 88 \\
9 / 23 / 88 \\
9 / 23 / 88 \\
9 / 23 / 88 \\
9 / 23 / 88 \\
9 / 23 / 88 \\
9 / 23 / 88 \\
9 / 23 / 88 \\
9 / 23 / 88 \\
9 / 23 / 88 \\
9 / 23 / 88 \\
9 / 23 / 88 \\
9 / 23 / 88 \\
9 / 23 / 88 \\
9 / 23 / 88 \\
9 / 23 / 88 \\
9 / 23 / 88 \\
9 / 23 / 88 \\
9 / 23 / 88 \\
9 / 23 / 88 \\
9 / 23 / 88\end{array}$ & $\begin{array}{l}\text { RU-106 } \\
\text { SAFROL } \\
\text { SELENUM } \\
\text { SILVER } \\
\text { SODIUM } \\
\text { SR 90 } \\
\text { STRONUM } \\
\text { STRYCHN } \\
\text { SULFATE } \\
\text { SULFIDE } \\
\text { SYMTRIN } \\
\text { TC } \\
\text { TC-99 } \\
\text { TETEPYR } \\
\text { TETRANE } \\
\text { TETRCHB } \\
\text { TETRCHP } \\
\text { THALIUM } \\
\text { THIONOX } \\
\text { THIOURA } \\
\text { THIURAM } \\
\text { TOC } \\
\text { TOC } \\
\text { TOC } \\
\text { TOLUOIA } \\
\text { TOLUENE } \\
\text { TOXAENE } \\
\text { TOXLDL } \\
\text { TOXLDL } \\
\text { TOXLDL } \\
\text { TRANOCE } \\
\text { TRCMEOL } \\
\text { TRCMFLM } \\
\text { TRCPANE } \\
\text { TRIBUPH } \\
\text { TRICENE } \\
\text { TRICHLB } \\
\text { TRIPHOS } \\
\text { TRISPHO } \\
\text { TRITIIUM } \\
\text { U-CHEM } \\
\text { VANADUM } \\
\text { VINYIOE } \\
\text { WARFRIN } \\
\text { ZINC }\end{array}$ & $\begin{array}{l}< \\
< \\
< \\
< \\
< \\
< \\
< \\
< \\
< \\
< \\
< \\
< \\
< \\
< \\
< \\
< \\
< \\
< \\
< \\
< \\
< \\
< \\
< \\
< \\
< \\
< \\
< \\
< \\
< \\
< \\
< \\
< \\
< \\
< \\
<\end{array}$ & $\begin{array}{r}-2.9700 \mathrm{E}+00 \\
1.0000 \mathrm{E}+01 \\
9.0000 \mathrm{E}+00 \\
1.0000 \mathrm{E}+01 \\
3.3300 \mathrm{E}+04 \\
1.7400 \mathrm{E}-01 \\
2.8300 \mathrm{E}+02 \\
5.0000 \mathrm{E}+01 \\
1.5000 \mathrm{E}+05 \\
1.0000 \mathrm{E}+03 \\
1.0000 \mathrm{E}+01 \\
2.0900 \mathrm{E}+04 \\
-3.6300 \mathrm{E}+00 \\
2.0000 \mathrm{E}+00 \\
5.0000 \mathrm{E}+00 \\
1.0000 \mathrm{E}+01 \\
1.0000 \mathrm{E}+01 \\
5.0000 \mathrm{E}+00 \\
1.0000 \mathrm{E}+01 \\
2.0000 \mathrm{E}+02 \\
1.0000 \mathrm{E}+01 \\
3.0000 \mathrm{E}+02 \\
4.0000 \mathrm{E}+02 \\
5.0000 \mathrm{E}+02 \\
1.0000 \mathrm{E}+01 \\
5.0000 \mathrm{E}+00 \\
1.0000 \mathrm{E}+00 \\
4.0000 \mathrm{E}+00 \\
6.0000 \mathrm{E}+00 \\
7.0000 \mathrm{E}+00 \\
1.0000 \mathrm{E}+01 \\
1.0000 \mathrm{E}+01 \\
1.0000 \mathrm{E}+01 \\
1.0000 \mathrm{E}+01 \\
1.0000 \mathrm{E}+01 \\
5.0000 \mathrm{E}+00 \\
1.0000 \mathrm{E}+01 \\
1.0000 \mathrm{E}+01 \\
1.0000 \mathrm{E}+01 \\
2.1000 \mathrm{E}+03 \\
3.4500 \mathrm{E}+00 \\
2.7000 \mathrm{E}+01 \\
1.0000 \mathrm{E}+01 \\
1.0000 \mathrm{E}+01 \\
1.9000 \mathrm{E}+01\end{array}$ & $\begin{array}{l}\text { PCI/L } \\
\text { PPB } \\
\text { PPB } \\
\text { PPB } \\
\text { PPB } \\
\text { PCI/L } \\
\text { PPB } \\
\text { PPB } \\
\text { PPB } \\
\text { PPB } \\
\text { PPB } \\
\text { PPB } \\
\text { PCI/L } \\
\text { PPB } \\
\text { PPB } \\
\text { PPB } \\
\text { PPB } \\
\text { PPB } \\
\text { PPB } \\
\text { PPB } \\
\text { PPB } \\
\text { PPB } \\
\text { PPB } \\
\text { PPB } \\
\text { PPB } \\
\text { PPB } \\
\text { PPB } \\
\text { PPB } \\
\text { PPB } \\
\text { PPB } \\
\text { PPB } \\
\text { PPB } \\
\text { PPB } \\
\text { PPB } \\
\text { PPB } \\
\text { PPB } \\
\text { PPB } \\
\text { PPB } \\
\text { PPB } \\
\text { PCI/L } \\
\text { UG /L } \\
\text { PPB } \\
\text { PPB } \\
\text { PPB } \\
\text { PPB }\end{array}$ \\
\hline
\end{tabular}


TABLE B.2. (contd)

\begin{tabular}{|c|c|c|c|c|c|}
\hline $\begin{array}{l}\text { HELL } \\
\text { NAME }\end{array}$ & $\begin{array}{c}\text { COLLECTION } \\
\text { DATE }\end{array}$ & $\begin{array}{l}\text { CONST I TUENT } \\
\text { NAME }\end{array}$ & $\begin{array}{l}\text { LESS } \\
\text { THAN } \\
\text { FLAG }\end{array}$ & $\begin{array}{l}\text { ANALYSIS } \\
\text { VALUE }\end{array}$ & $\begin{array}{l}\text { ANALYSIS } \\
\text { UNITS }\end{array}$ \\
\hline $2-E 34-2$ & $9 / 23 / 88$ & $a-B H C$ & $<$ & $1.0000 E-01$ & PPB \\
\hline $2-E 34-2$ & $9 / 23 / 88$ & $\mathrm{~b}-\mathrm{BHC}$ & $<$ & $1.0000 E-01$ & PPB \\
\hline $2-E 34-2$ & $9 / 23 / 88$ & $d-B H C$ & $<$ & $1.0000 \mathrm{E}-01$ & PPB \\
\hline $2-E 34-2$ & $9 / 23 / 88$ & $g-B H C$ & $<$ & $1.0000 E-01$ & PPB \\
\hline $2-E 34-3$ & $9 / 23 / 88$ & $1,1,1-T$ & $<$ & $5.0000 E+00$ & PPB \\
\hline $2-E 34-3$ & $9 / 23 / 88$ & $1,1,2-T$ & $<$ & $5.0000 E+00$ & PPB \\
\hline $2-E 34-3$ & $9 / 23 / 88$ & $1,1-0 I C$ & $<$ & $1.0000 \mathrm{E}+01$ & PPB \\
\hline $2-E 34-3$ & $9 / 23 / 88$ & $1,2-0 I C$ & $<$ & $1.0000 \mathrm{E}+01$ & PPB \\
\hline $2-E 34-3$ & $9 / 23 / 88$ & 1-napha & $<$ & $1.0000 \mathrm{E}+01$ & PPB \\
\hline $2-E 34-3$ & $9 / 23 / 88$ & $1112-t c$ & $<$ & $1.0000 \mathrm{E}+01$ & PPB \\
\hline $2-E 34-3$ & $9 / 23 / 88$ & $1122-t c$ & $<$ & $1.0000 \mathrm{E}+0 \mathrm{I}$ & PPB \\
\hline $2-E 34-3$ & $9 / 23 / 88$ & 12-dben & $<$ & $1.0000 E+01$ & PPB \\
\hline $2-E 34-3$ & $9 / 23 / 88$ & 123-trp & $<$ & $1.0000 E+01$ & PPB \\
\hline $2-E 34-3$ & $9 / 23 / 88$ & $1234 \mathrm{TE}$ & $<$ & $1.0000 E+01$ & PPB \\
\hline $2-E 34-3$ & $9 / 23 / 88$ & 1235TE & $<$ & $1.0000 \mathrm{E}+01$ & PPB \\
\hline $2-E 34-3$ & $9 / 23 / 88$ & 123TRI & $<$ & $1.0000 \mathrm{E}+01$ & PPB \\
\hline$\hat{c}-E 34-3$ & $9 / 23 / 88$ & 13-dben & $<$ & $1.0000 E+01$ & PPB \\
\hline $2-E 34-3$ & $9 / 23 / 88$ & 135TRI & $<$ & $1.0000 E+01$ & PPB \\
\hline $2-E 34-3$ & $9 / 23 / 88$ & 14-dben & $<$ & $1.0000 E+01$ & PPB \\
\hline $2-E 34-3$ & $9 / 23 / 88$ & $2,4,5-T$ & $<$ & $2.0000 E+00$ & PPB \\
\hline $2-E 34-3$ & $9 / 23 / 88$ & $2,4,5 \mathrm{TP}$ & $<$ & $2.0000 E+00$ & PPB \\
\hline $2-E 34-3$ & $9 / 23 / 88$ & $2,4-0$ & $<$ & $2.0000 E+00$ & PPB \\
\hline $2-E 34-3$ & $9 / 23 / 88$ & 2-napha & $<$ & $1.0000 \mathrm{E}+01$ & PPB \\
\hline $2-E 34-3$ & $9 / 23 / 88$ & $24-d \operatorname{chp}$ & $<$ & $1.0000 \mathrm{E}+01$ & PPB \\
\hline $2-E 34-3$ & $9 / 23 / 88$ & 24-dint & $<$ & $1.0000 \mathrm{E}+01$ & PPB \\
\hline $2-E 34-3$ & $9 / 23 / 88$ & $245-t r p$ & $<$ & $5.0000 \mathrm{E}+01$ & PPB \\
\hline $2-E 34-3$ & $9 / 23 / 88$ & 246-trp & $<$ & $1.0000 E+01$ & PPB \\
\hline $2-E 34-3$ & $9 / 23 / 88$ & 26-dchp & $<$ & $1.0000 E+01$ & PPB \\
\hline $2-E 34-3$ & $9 / 23 / 88$ & 26-dint & $<$ & $1.0000 E+01$ & PPB \\
\hline $2-E 34-3$ & $9 / 23 / 88$ & ACEFENE & $<$ & $1.0000 E+01$ & PPB \\
\hline $2-E 34-3$ & $9 / 23 / 88$ & ACETILE & $<$ & $3.0000 E+03$ & PPB \\
\hline $2-E 34-3$ & $9 / 23 / 88$ & ACETOPH & $<$ & $1.0000 E+01$ & PPB \\
\hline $4-3$ & $9 / 23 / 88$ & ACETREA & $<$ & $2.0000 \mathrm{E}+02$ & $\mathrm{PPB}$ \\
\hline $4-3$ & $9 / 23 / 88$ & ACROL IN & $<$ & $1.0000 E+01$ & $\mathrm{PPB}$ \\
\hline $4-3$ & $9 / 23 / 88$ & ACRYIDE & $<$ & $1.0000 E+04$ & PPB \\
\hline $4-3$ & $9 / 23 / 88$ & ACRYILE & $<$ & $1.0000 E+01$ & PPB \\
\hline $4-3$ & $9 / 23 / 88$ & ALORIN & $<$ & $1.0000 E-01$ & $\mathrm{PPB}$ \\
\hline $4-3$ & $9 / 23 / 88$ & ALLYLAL & $<$ & $2.5000 E+03$ & PPB \\
\hline $4-3$ & $9 / 23 / 88$ & ALPHA & & $1.2700 \mathrm{E}+00$ & $\mathrm{PCI} / \mathrm{L}$ \\
\hline $4-3$ & $9 / 23 / 88$ & ALUMNUM & $<$ & $1.5000 E+02$ & PPB \\
\hline $4-3$ & $9 / 23 / 88$ & AMI ISOX & $<$ & $1.0000 E+01$ & PPB \\
\hline $4-3$ & $9 / 23 / 88$ & AMINOYL & $<$ & $1.0000 E+01$ & PPB \\
\hline $4-3$ & $9 / 23 / 88$ & AMITROL & $<$ & $1.0000 E+01$ & PPB \\
\hline $4-3$ & $9 / 23 / 88$ & AMMONIU & $<$ & $5.0000 \mathrm{E}+01$ & PPB \\
\hline $34-3$ & $9 / 23 / 88$ & ANILINE & $<$ & $1.0000 \mathrm{E}+01$ & PPB \\
\hline
\end{tabular}


TABLE B.2. (contd)

\begin{tabular}{|c|c|c|c|c|c|}
\hline $\begin{array}{l}\text { WELL } \\
\text { NAME }\end{array}$ & $\begin{array}{c}\text { COLLECTION } \\
\text { DATE }\end{array}$ & $\begin{array}{l}\text { CONST ITUENT } \\
\text { NAME }\end{array}$ & $\begin{array}{l}\text { LESS } \\
\text { THAN } \\
\text { FLAG }\end{array}$ & $\begin{array}{l}\text { ANALYSIS } \\
\text { VALUE }\end{array}$ & $\begin{array}{l}\text { ANALYSIS } \\
\text { UNITS }\end{array}$ \\
\hline $\begin{array}{l}2-E 33-18 \\
2-E 33-18 \\
2-E 33-18 \\
2-E 33-18 \\
2-E 33-18 \\
2-E 33-18 \\
2-E 33-18 \\
2-E 33-18 \\
2-E 33-18 \\
2-E 33-18 \\
2-E 33-18 \\
2-E 33-18 \\
2-E 33-18 \\
2-E 33-18 \\
2-E 33-18 \\
2-E 33-18 \\
2-E 33-18 \\
2-E 33-18 \\
2-E 33-18 \\
2-E 33-18 \\
2-E 33-18 \\
2-E 33-18 \\
2-E 33-18\end{array}$ & $\begin{array}{r}1 / 03 / 85 \\
1 / 03 / 85 \\
1 / 03 / 85 \\
1 / 03 / 85 \\
1 / 03 / 85 \\
2 / 13 / 85 \\
2 / 13 / 85 \\
2 / 13 / 85 \\
2 / 13 / 85 \\
2 / 13 / 85 \\
4 / 15 / 85 \\
4 / 15 / 85 \\
4 / 15 / 85 \\
4 / 15 / 85 \\
4 / 15 / 85 \\
9 / 05 / 85 \\
9 / 05 / 85 \\
9 / 05 / 85 \\
9 / 05 / 85 \\
9 / 05 / 85 \\
12 / 19 / 85 \\
12 / 19 / 85 \\
12 / 19 / 85\end{array}$ & $\begin{array}{l}\text { BETA } \\
\text { CO-60 } \\
\text { CS-137 } \\
\text { RU-106 } \\
\text { SR 90 } \\
\text { BETA } \\
\text { CO-60 } \\
\text { CS-137 } \\
\text { RU-106 } \\
\text { SR 90 } \\
\text { BETA } \\
\text { CO-60 } \\
\text { CS-137 } \\
\text { RU-106 } \\
\text { SR 90 } \\
\text { BETA } \\
\text { CO-60 } \\
\text { CS- } 137 \\
\text { RU-106 } \\
\text { SR 90 } \\
\text { BETA } \\
\text { CO-60 } \\
\text { CS- } 137\end{array}$ & $\begin{array}{l}< \\
< \\
< \\
< \\
< \\
<\end{array}$ & $\begin{array}{r}1.1800 \mathrm{E}+01 \\
4.5100 \mathrm{E}+00 \\
3.7900 \mathrm{E}+00 \\
-8.7100 \mathrm{E}+00 \\
-4.8200 \mathrm{E}-01 \\
1.1200 \mathrm{E}+01 \\
-1.7000 \mathrm{E}+00 \\
-2.0700 \mathrm{E}+00 \\
2.9700 \mathrm{E}+01 \\
6.3800 \mathrm{E}-01 \\
1.4100 \mathrm{E}+01 \\
-3.0200 \mathrm{E}+00 \\
7.6500 \mathrm{E}+00 \\
6.0700 \mathrm{E}+01 \\
1.4100 \mathrm{E}-01 \\
1.1000 \mathrm{E}+01 \\
-4.5500 \mathrm{E}+00 \\
4.7900 \mathrm{E}+00 \\
8.0100 \mathrm{E}+00 \\
3.5400 \mathrm{E}-01 \\
1.0800 \mathrm{E}+01 \\
-2.9500 \mathrm{E}+00 \\
1.0700 \mathrm{E}+00\end{array}$ & $\begin{array}{l}\text { PCI/L } \\
P C I / L \\
P C I / L \\
P C I / L \\
P C I / L \\
P C I / L \\
P C I / L \\
P C I / L \\
P C I / L \\
P C I / L \\
P C I / L \\
P C I / L \\
P C I / L \\
P C I / L \\
P C I / L \\
P C I / L \\
P C I / L \\
P C I / L \\
P C I / L \\
P C I / L \\
P C I / L \\
P C I / L \\
P C I / L\end{array}$ \\
\hline
\end{tabular}


TABLE B.2. (contd)

\begin{tabular}{|c|c|c|c|c|c|}
\hline $\begin{array}{l}\text { WELL } \\
\text { NAME }\end{array}$ & $\begin{array}{l}\text { COLLECTION } \\
\text { DATE }\end{array}$ & $\begin{array}{c}\text { CONSTITUENT } \\
\text { NAME }\end{array}$ & $\begin{array}{l}\text { LESS } \\
\text { THAN } \\
\text { FLAG }\end{array}$ & $\begin{array}{l}\text { ANALYSIS } \\
\text { VALUE }\end{array}$ & $\begin{array}{l}\text { ANALYSIS } \\
\text { UNITS }\end{array}$ \\
\hline $\begin{array}{l}2-E 33-18 \\
2-E 33-18 \\
2-E 33-18 \\
2-E 33-18 \\
2-E 33-18 \\
2-E 33-18 \\
2-E 33-18 \\
2-E 33-18 \\
2-E 33-18 \\
2-E 33-18 \\
2-E 33-18 \\
2-E 33-18 \\
2-E 33-18 \\
2-E 33-18 \\
2-E 33-18 \\
2-E 33-18 \\
2-E 33-18 \\
2-E 33-18 \\
2-E 33-18 \\
2-E 33-18 \\
2-E 33-18 \\
2-E 33-18 \\
2-E 33-18 \\
2-E 33-18 \\
2-E 33-18 \\
2-E 33-18 \\
2-E 33-18 \\
2-E 33-18 \\
2-E 33-18 \\
2-E 33-18 \\
2-E 33-18 \\
2-E 33-18 \\
2-E 33-18 \\
2-E 33-18 \\
2-E 33-18 \\
2-E 33-18 \\
2-E 33-18 \\
2-E 33-18 \\
2-E 33-18 \\
2-E 33-18 \\
2-E 33-18 \\
2-E 33-18 \\
2-E 33-18 \\
2-E 33-18 \\
2-E 33-18\end{array}$ & $\begin{array}{r}12 / 19 / 85 \\
12 / 19 / 85 \\
2 / 27 / 86 \\
2 / 27 / 86 \\
2 / 27 / 86 \\
2 / 27 / 86 \\
2 / 27 / 86 \\
5 / 05 / 86 \\
5 / 05 / 86 \\
5 / 05 / 86 \\
5 / 05 / 86 \\
5 / 05 / 86 \\
8 / 11 / 86 \\
8 / 11 / 86 \\
8 / 11 / 86 \\
8 / 11 / 86 \\
8 / 11 / 86 \\
10 / 29 / 86 \\
10 / 29 / 86 \\
10 / 29 / 86 \\
10 / 29 / 86 \\
10 / 29 / 86 \\
3 / 24 / 87 \\
3 / 24 / 87 \\
3 / 24 / 87 \\
3 / 24 / 87 \\
3 / 24 / 87 \\
3 / 24 / 87 \\
3 / 24 / 87 \\
3 / 24 / 87 \\
3 / 24 / 87 \\
3 / 24 / 87 \\
3 / 24 / 87 \\
3 / 24 / 87 \\
3 / 24 / 87 \\
3 / 24 / 87 \\
3 / 24 / 87 \\
3 / 24 / 87 \\
3 / 24 / 87 \\
3 / 24 / 87 \\
3 / 24 / 87 \\
3 / 24 / 87 \\
3 / 24 / 87 \\
3 / 24 / 87 \\
3 / 24 / 87\end{array}$ & $\begin{array}{l}\text { RU-106 } \\
\text { SR 90 } \\
\text { BETA } \\
\text { C0-60 } \\
\text { CS-137 } \\
\text { RU-106 } \\
\text { SR 90 } \\
\text { BETA } \\
\text { C0-60 } \\
\text { CS-137 } \\
\text { RU-106 } \\
\text { SR 90 } \\
\text { BETA } \\
\text { CO-60 } \\
\text { CS-137 } \\
\text { RU-106 } \\
\text { SR 90 } \\
\text { BETA } \\
\text { CO-60 } \\
\text { CS-137 } \\
\text { RU-106 } \\
\text { SR 90 } \\
1,1,1-T \\
\text { 1,1.2-T } \\
\text { ALKALIN } \\
\text { ALPHA } \\
\text { AMMONIU } \\
\text { BETA } \\
\text { BETA } \\
\text { CHLF0RM } \\
\text { CHLORID } \\
\text { C0-60 } \\
\text { CONDFLD } \\
\text { CS-137 } \\
\text { CYANIDE } \\
\text { FALUMIN } \\
\text { FANTIM0 } \\
\text { FARSENI } \\
\text { FBARIUM } \\
\text { FBERYLL } \\
\text { FCADMIU } \\
\text { FCALCIU } \\
\text { FCHROMI } \\
\text { FCOPPER } \\
\text { FIRON }\end{array}$ & $\begin{array}{l} \\
< \\
< \\
< \\
\\
< \\
< \\
\\
< \\
< \\
< \\
< \\
< \\
<\end{array}$ & $\begin{array}{r}-2.3600 E+01 \\
2.5400 E-01 \\
1.1400 E+01 \\
-1.5100 E+00 \\
-8.6200 E+00 \\
-1.5800 E+01 \\
4.2700 E-01 \\
1.4900 E+01 \\
6.7700 E+00 \\
6.1900 E+00 \\
-3.7700 E+01 \\
-2.1100 E-01 \\
1.3000 E+01 \\
6.8200 E+00 \\
-6.8900 E-01 \\
-1.5100 E+01 \\
2.6600 E+00 \\
8.7700 E+00 \\
5.6300 E-01 \\
4.8200 E+00 \\
1.4400 E+01 \\
3.7100 E-01 \\
1.0000 E+01 \\
1.0000 E+01 \\
9.6000 E+04 \\
2.6200 E+00 \\
5.0000 E+01 \\
8.6300 E+00 \\
1.4900 E+01 \\
1.0000 E+01 \\
2.6700 E+03 \\
-1.8300 E+00 \\
2.3300 E+02 \\
3.0200 E+00 \\
1.0000 E+01 \\
1.5000 E+02 \\
1.0000 E+02 \\
8.0000 E+00 \\
1.9000 E+01 \\
5.0000 E+00 \\
2.0000 E+00 \\
2.5200 E+04 \\
1.0000 E+01 \\
1.0000 E+01 \\
5.0000 E+01\end{array}$ & $\begin{array}{l}\mathrm{PCI} I / \mathrm{L} \\
\mathrm{PCI} / \mathrm{L} \\
\mathrm{PCI} / \mathrm{L} \\
\mathrm{PCI} / \mathrm{L} \\
\mathrm{PCI} / \mathrm{L} \\
\mathrm{PCI} / \mathrm{L} \\
\mathrm{PCI} / \mathrm{L} \\
\mathrm{PCI} / \mathrm{L} \\
\mathrm{PCI} / \mathrm{L} \\
\mathrm{PCI} / \mathrm{L} \\
\mathrm{PCI} / \mathrm{L} \\
\mathrm{PCI} / \mathrm{L} \\
\mathrm{PCI} / \mathrm{L} \\
\mathrm{PCI} / \mathrm{L} \\
\mathrm{PCI} / \mathrm{L} \\
\mathrm{PCI} / \mathrm{L} \\
\mathrm{PCI} / \mathrm{L} \\
\mathrm{PCI} / \mathrm{L} \\
\mathrm{PCI} / \mathrm{L} \\
\mathrm{PCI} / \mathrm{L} \\
\mathrm{PCI} / \mathrm{L} \\
\mathrm{PCI} / \mathrm{L} \\
\mathrm{PPB} \\
\mathrm{PPB} \\
\mathrm{PCI} \\
\mathrm{PPB} \\
\mathrm{PCI} / \mathrm{L} \\
\mathrm{PCI} / \mathrm{L} \\
\mathrm{PPB} \\
\mathrm{PPB} \\
\mathrm{PCI} / \mathrm{L} \\
\mathrm{UMH} 0 \\
\mathrm{PCI} / \mathrm{L} \\
\mathrm{PPB} \\
\mathrm{PPB} \\
\mathrm{PPB} \\
\mathrm{PPB} \\
\mathrm{PPB} \\
\mathrm{PPB} \\
\mathrm{PPB} \\
\mathrm{PPB} \\
\mathrm{PPB} \\
\mathrm{PPB} \\
\mathrm{PPB}\end{array}$ \\
\hline
\end{tabular}


TABLE B.2. (contd)

\begin{tabular}{|c|c|c|c|c|c|}
\hline $\begin{array}{l}\text { WELL } \\
\text { NAME }\end{array}$ & $\begin{array}{c}\text { COLLECTION } \\
\text { DATE }\end{array}$ & $\begin{array}{l}\text { CONST I TUENT } \\
\text { NAME }\end{array}$ & $\begin{array}{l}\text { LESS } \\
\text { THAN } \\
\text { FLAG }\end{array}$ & $\begin{array}{l}\text { ANALYSIS } \\
\text { VALUE }\end{array}$ & $\begin{array}{l}\text { ANALYSIS } \\
\text { UNITS }\end{array}$ \\
\hline $\begin{array}{l}2-E 33-18 \\
2-E 33-18 \\
2-E 33-18 \\
2-E 33-18 \\
2-E 33-18 \\
2-E 33-18 \\
2-E 33-18 \\
2-E 33-18 \\
2-E 33-18 \\
2-E 33-18 \\
2-E 33-18 \\
2-E 33-18 \\
2-E 33-18 \\
2-E 33-18 \\
2-E 33-18 \\
2-E 33-18 \\
2-E 33-18 \\
2-E 33-18 \\
2-E 33-18 \\
2-E 33-18 \\
2-E 33-18 \\
2-E 33-18 \\
2-E 33-18 \\
2-E 33-18 \\
2-E 33-18 \\
2-E 33-18 \\
2-E 33-18 \\
2-E 33-18 \\
2-E 33-18 \\
2-E 33-18 \\
2-E 33-18 \\
2-E 33-18 \\
2-E 33-18 \\
2-E 33-18 \\
2-E 33-18 \\
2-E 33-18 \\
2-E 33-18 \\
2-E 33-18 \\
2-E 33-18 \\
2-E 33-18 \\
2-E 33-18 \\
2-E 33-18 \\
2-E 33-18 \\
2-E 33-18 \\
2-E 33-18\end{array}$ & $\begin{array}{l}3 / 24 / 87 \\
3 / 24 / 87 \\
3 / 24 / 87 \\
3 / 24 / 87 \\
3 / 24 / 87 \\
3 / 24 / 87 \\
3 / 24 / 87 \\
3 / 24 / 87 \\
3 / 24 / 87 \\
3 / 24 / 87 \\
3 / 24 / 87 \\
3 / 24 / 87 \\
3 / 24 / 87 \\
3 / 24 / 87 \\
3 / 24 / 87 \\
3 / 24 / 87 \\
3 / 24 / 87 \\
3 / 24 / 87 \\
3 / 24 / 87 \\
3 / 24 / 87 \\
3 / 24 / 87 \\
3 / 24 / 87 \\
3 / 24 / 87 \\
3 / 24 / 87 \\
3 / 24 / 87 \\
3 / 24 / 87 \\
3 / 24 / 87 \\
3 / 24 / 87 \\
3 / 24 / 87 \\
3 / 24 / 87 \\
3 / 24 / 87 \\
3 / 24 / 87 \\
3 / 24 / 87 \\
3 / 24 / 87 \\
3 / 24 / 87 \\
5 / 19 / 87 \\
5 / 19 / 87 \\
5 / 19 / 87 \\
5 / 19 / 87 \\
5 / 19 / 87 \\
5 / 19 / 87 \\
5 / 19 / 87 \\
5 / 19 / 87 \\
5 / 19 / 87 \\
5 / 19 / 87\end{array}$ & $\begin{array}{l}\text { FLEAD } \\
\text { FLUORID } \\
\text { FMAGNES } \\
\text { FMANGAN } \\
\text { FMERCUR } \\
\text { FNICKEL } \\
\text { FOSMIUM } \\
\text { FPOTASS } \\
\text { FSELENI } \\
\text { FSILVER } \\
\text { FSODIUM } \\
\text { FSTRONT } \\
\text { FVANADI } \\
\text { FZINC } \\
\text { M-XYLE } \\
\text { METHONE } \\
\text { METHYCH } \\
\text { NITRATE } \\
\text { OPXYLE } \\
\text { PERCENE } \\
\text { PH-LAB } \\
\text { PHFIELD } \\
\text { PHOSPHA } \\
\text { PU-238 } \\
\text { PU39-40 } \\
\text { RADIUM } \\
\text { RU-106 } \\
\text { SR 90 } \\
\text { SULFATE } \\
\text { TETRANE } \\
\text { TOC } \\
\text { TOXLDL } \\
\text { TRICENE } \\
\text { TRITIUM } \\
\text { U } \\
1,1,1-T \\
1,1,2-T \\
\text { ALKALIN } \\
\text { ALPHA } \\
\text { AMMONIU } \\
\text { BETA } \\
\text { BETA } \\
\text { CHLFORM } \\
\text { CHLORID } \\
\text { CO-60 }\end{array}$ & $\begin{array}{l}< \\
< \\
< \\
< \\
< \\
< \\
\\
< \\
< \\
< \\
< \\
< \\
< \\
< \\
< \\
< \\
< \\
<\end{array}$ & $\begin{array}{r}5.0000 E+00 \\
5.0000 E+02 \\
8.6300 E+03 \\
5.0000 E+00 \\
1.0000 E-01 \\
1.0000 E+01 \\
3.0000 E+02 \\
4.6200 E+03 \\
5.0000 E+00 \\
1.0000 E+01 \\
1.3800 E+04 \\
3.0000 E+02 \\
2.7000 E+01 \\
5.0000 E+00 \\
1.0000 E+01 \\
1.0000 E+01 \\
1.0000 E+01 \\
1.7200 E+04 \\
1.0000 E+01 \\
1.0000 E+01 \\
7.8800 E+00 \\
8.1000 E+00 \\
1.0000 E+03 \\
0.0000 E+00 \\
-5.7100 E-03 \\
4.0200 E-02 \\
4.7700 E+01 \\
6.6500 E-01 \\
2.6800 E+04 \\
1.0000 E+01 \\
5.2900 E+02 \\
2.0000 E+01 \\
1.0000 E+01 \\
4.6700 E+02 \\
1.1800 E+00 \\
1.0000 E+01 \\
1.0000 E+01 \\
9.4000 E+04 \\
1.1900 E+00 \\
5.9000 E+01 \\
8.8500 E+00 \\
1.1500 E+01 \\
1.0000 E+01 \\
2.2300 E+03 \\
2.8100 E+00\end{array}$ & $\begin{array}{l}\text { PPB } \\
\mathrm{PPB} \\
\mathrm{PPB} \\
\mathrm{PPB} \\
\mathrm{PPB} \\
\mathrm{PPB} \\
\mathrm{PPB} \\
\mathrm{PPB} \\
\mathrm{PPB} \\
\mathrm{PPB} \\
\mathrm{PPB} \\
\mathrm{PPB} \\
\mathrm{PPB} \\
\mathrm{PPB} \\
\mathrm{PPB} \\
\mathrm{PPB} \\
\mathrm{PPB} \\
\mathrm{PPB} \\
\mathrm{PPB} \\
\mathrm{PPB} \\
\\
\mathrm{PPB} \\
\mathrm{PCI} \mathrm{I} / \mathrm{L} \\
\mathrm{PCI} / \mathrm{L} \\
\mathrm{PCI} / \mathrm{L} \\
\mathrm{PCI} / \mathrm{L} \\
\mathrm{PCI} \mathrm{L} \\
\mathrm{PPB} \\
\mathrm{PPB} \\
\mathrm{PPB} \\
\mathrm{PPB} \\
\mathrm{PPB} \\
\mathrm{PCI} / \mathrm{L} \\
\mathrm{PCI} / \mathrm{L} \\
\mathrm{PPB} \\
\mathrm{PPB} \\
\mathrm{PCI} / \mathrm{L} \\
\mathrm{PPB} \\
\mathrm{PCI} / \mathrm{L} \\
\mathrm{PCI} / \mathrm{L} \\
\mathrm{PPB} \\
\mathrm{PPB} \\
\mathrm{PCI} / \mathrm{L}\end{array}$ \\
\hline
\end{tabular}


TABLE_B.2. (contd)

\begin{tabular}{|c|c|c|c|c|c|}
\hline $\begin{array}{l}\text { WELL } \\
\text { NAME }\end{array}$ & $\begin{array}{l}\text { COLLECTION } \\
\text { DATE }\end{array}$ & $\begin{array}{l}\text { CONST ITUENT } \\
\text { NAME }\end{array}$ & $\begin{array}{l}\text { LESS } \\
\text { THAN } \\
\text { FLAG }\end{array}$ & $\begin{array}{l}\text { ANALYSIS } \\
\text { VALUE }\end{array}$ & $\begin{array}{l}\text { ANALYSIS } \\
\text { UNITS }\end{array}$ \\
\hline $\begin{array}{l}2-E 33-18 \\
2-E 33-18 \\
2-E 33-18 \\
2-E 33-18 \\
2-E 33-18 \\
2-E 33-18 \\
2-E 33-18 \\
2-E 33-18 \\
2-E 33-18 \\
2-E 33-18 \\
2-E 33-18 \\
2-E 33-18 \\
2-E 33-18 \\
2-E 33-18 \\
2-E 33-18 \\
2-E 33-18 \\
2-E 33-18 \\
2-E 33-18 \\
2-E 33-18 \\
2-E 33-18 \\
2-E 33-18 \\
2-E 33-18 \\
2-E 33-18 \\
2-E 33-18 \\
2-E 33-18 \\
2-E 33-18 \\
2-E 33-18 \\
2-E 33-18 \\
2-E 33-18 \\
2-E 33-18 \\
2-E 33-18 \\
2-E 33-18 \\
2-E 33-18 \\
2-E 33-18 \\
2-E 33-18 \\
2-E 33-18 \\
2-E 33-18 \\
2-E 33-18 \\
2-E 33-18 \\
2-E 33-18 \\
2-E 33-18 \\
2-E 33-18 \\
2-E 33-18 \\
2-E 33-18 \\
2-E 33-18\end{array}$ & $\begin{array}{l}5 / 19 / 87 \\
5 / 19 / 87 \\
5 / 19 / 87 \\
5 / 19 / 87 \\
5 / 19 / 87 \\
5 / 19 / 87 \\
5 / 19 / 87 \\
5 / 19 / 87 \\
5 / 19 / 87 \\
5 / 19 / 87 \\
5 / 19 / 87 \\
5 / 19 / 87 \\
5 / 19 / 87 \\
5 / 19 / 87 \\
5 / 19 / 87 \\
5 / 19 / 87 \\
5 / 19 / 87 \\
5 / 19 / 87 \\
5 / 19 / 87 \\
5 / 19 / 87 \\
5 / 19 / 87 \\
5 / 19 / 87 \\
5 / 19 / 87 \\
5 / 19 / 87 \\
5 / 19 / 87 \\
5 / 19 / 87 \\
5 / 19 / 87 \\
5 / 19 / 87 \\
5 / 19 / 87 \\
5 / 19 / 87 \\
5 / 19 / 87 \\
5 / 19 / 87 \\
5 / 19 / 87 \\
5 / 19 / 87 \\
5 / 19 / 87 \\
5 / 19 / 87 \\
5 / 19 / 87 \\
5 / 19 / 87 \\
5 / 19 / 87 \\
5 / 19 / 87 \\
5 / 19 / 87 \\
5 / 19 / 87 \\
5 / 19 / 87 \\
8 / 04 / 87 \\
8 / 04 / 87\end{array}$ & $\begin{array}{l}\text { CONDFLO } \\
\text { CS-137 } \\
\text { CYANIDE } \\
\text { FALUMIN } \\
\text { FANTIMO } \\
\text { FARSENI } \\
\text { FBARIUM } \\
\text { FBERYLL } \\
\text { FCADMIU } \\
\text { FCALCIU } \\
\text { FCHROMI } \\
\text { FCOPPER } \\
\text { FIRON } \\
\text { FLEAD } \\
\text { FLUORID } \\
\text { FMAGNES } \\
\text { FMANGAN } \\
\text { FMERCUR } \\
\text { FNICKEL } \\
\text { FOSMIUM } \\
\text { FPOTASS } \\
\text { FSELENI } \\
\text { FSILVER } \\
\text { FSODIUM } \\
\text { FSTRONT } \\
\text { FVANADI } \\
\text { FZINC } \\
\text { M-XYLE } \\
\text { METHONE } \\
\text { METHYCH } \\
\text { NITRATE } \\
\text { OPXYLE } \\
\text { PERCENE } \\
\text { PH-LAB } \\
\text { PHFIELD } \\
\text { PHOSPHA } \\
\text { RADIUM } \\
\text { RU-106 } \\
\text { SULFATE } \\
\text { TETRANE } \\
\text { IOC } \\
\text { TOXLDL } \\
\text { TRICENE } \\
1,1,1-T \\
1,1,2-T\end{array}$ & $\begin{array}{l}< \\
< \\
< \\
< \\
\\
< \\
< \\
\\
< \\
< \\
< \\
< \\
< \\
< \\
< \\
< \\
< \\
< \\
< \\
< \\
< \\
<\end{array}$ & $\begin{array}{r}2.2100 \mathrm{E}+02 \\
-8.5500 \mathrm{E}-01 \\
1.0000 \mathrm{E}+01 \\
1.5000 \mathrm{E}+02 \\
1.0000 \mathrm{E}+02 \\
8.0000 \mathrm{E}+00 \\
2.4000 \mathrm{E}+01 \\
5.0000 \mathrm{E}+00 \\
2.0000 \mathrm{E}+00 \\
2.7700 \mathrm{E}+04 \\
1.0000 \mathrm{E}+01 \\
1.0000 \mathrm{E}+01 \\
5.0000 \mathrm{E}+01 \\
5.0000 \mathrm{E}+00 \\
5.0000 \mathrm{E}+02 \\
9.4800 \mathrm{E}+03 \\
5.0000 \mathrm{E}+00 \\
1.0000 \mathrm{E}-01 \\
1.0000 \mathrm{E}+01 \\
3.0000 \mathrm{E}+02 \\
4.8500 \mathrm{E}+03 \\
5.0000 \mathrm{E}+00 \\
1.0000 \mathrm{E}+01 \\
1.4700 \mathrm{E}+04 \\
3.0000 \mathrm{E}+02 \\
2.6000 \mathrm{E}+01 \\
5.0000 \mathrm{E}+00 \\
1.0000 \mathrm{E}+01 \\
1.0000 \mathrm{E}+01 \\
1.0000 \mathrm{E}+01 \\
1.6700 \mathrm{E}+04 \\
1.0000 \mathrm{E}+01 \\
1.0000 \mathrm{E}+01 \\
7.8400 \mathrm{E}+00 \\
7.8000 \mathrm{E}+00 \\
1.0000 \mathrm{E}+03 \\
9.0500 \mathrm{E}-03 \\
-5.7900 \mathrm{E}+01 \\
2.7600 \mathrm{E}+04 \\
1.0000 \mathrm{E}+01 \\
4.1200 \mathrm{E}+02 \\
2.0000 \mathrm{E}+01 \\
1.0000 \mathrm{E}+01 \\
1.0000 \mathrm{E}+01 \\
1.0000 \mathrm{E}+01\end{array}$ & $\begin{array}{l}\text { UMHO } \\
\text { PCI/L } \\
\text { PPB } \\
\text { PPB } \\
\text { PPB } \\
\text { PPB } \\
\text { PPB } \\
\text { PPB } \\
\text { PPB } \\
\text { PPB } \\
\text { PPB } \\
\text { PPB } \\
\text { PPB } \\
\text { PPB } \\
\text { PPB } \\
\text { PPB } \\
\text { PPB } \\
\text { PPB } \\
\text { PPB } \\
\text { PPB } \\
\text { PPB } \\
\text { PPB } \\
\text { PPB } \\
\text { PPB } \\
\text { PPB } \\
\text { PPB } \\
\text { PPB } \\
\text { PPB } \\
\text { PPB } \\
\text { PPB } \\
\text { PPB } \\
\text { PPB } \\
\text { PPB } \\
\text { PPB } \\
\text { PPB } \\
\text { PPB }\end{array}$ \\
\hline
\end{tabular}


TABLE B.2. (contd)

\begin{tabular}{|c|c|c|c|c|c|}
\hline $\begin{array}{l}\text { WELL } \\
\text { NAME }\end{array}$ & $\begin{array}{c}\text { COLLECTION } \\
\text { DATE }\end{array}$ & $\begin{array}{l}\text { CONSTITUENT } \\
\text { NAME }\end{array}$ & $\begin{array}{l}\text { LESS } \\
\text { THAN } \\
\text { FLAG }\end{array}$ & $\begin{array}{l}\text { ANALYSIS } \\
\text { VALUE }\end{array}$ & $\begin{array}{l}\text { ANALYSIS } \\
\text { UNITS }\end{array}$ \\
\hline $2-E 33-18$ & $8 / 04 / 87$ & $1,1-D I C$ & $<$ & $1.0000 E+01$ & PPB \\
\hline $2-E 33-18$ & $8 / 04 / 87$ & $1,2-D I C$ & $<$ & 1. $0000 \mathrm{E}+01$ & PPB \\
\hline $2-E 33-18$ & $8 / 04 / 87$ & $1112-\mathrm{tc}$ & $<$ & $1.0000 E+01$ & PPB \\
\hline $2-E 33-1 B$ & $8 / 04 / 87$ & $1122-\mathrm{tc}$ & $<$ & $1.0000 E+01$ & PPB \\
\hline $2-E 33-18$ & $8 / 04 / 87$ & $123-\mathrm{trp}$ & $<$ & 1. $0000 \mathrm{E}+01$ & PPB \\
\hline $2-E 33-18$ & $8 / 04 / 87$ & ACROLIN & $<$ & $1.0000 \mathrm{E}+01$ & PPB \\
\hline $2-E 33-18$ & $8 / 04 / 87$ & ACRYILE & $<$ & $1.0000 E+01$ & PPB \\
\hline $2-E 33-18$ & $8 / 04 / 87$ & ALKALIN & & $9.6600 \mathrm{E}+04$ & \\
\hline $2-E 33-18$ & $8 / 04 / 87$ & ALPHA & & $1.5000 \mathrm{E}+00$ & $\mathrm{PCl} / \mathrm{L}$ \\
\hline $2-E 33-18$ & $8 / 04 / 87$ & AMMONIU & $<$ & $5.0000 \mathrm{E}+01$ & PPB \\
\hline $2-E 33-18$ & $8 / 04 / 87$ & BENZENE & $<$ & $1.0000 \mathrm{E}+01$ & PPB \\
\hline $2-E 33-18$ & $8 / 04 / 87$ & BETA & & $1.0800 \mathrm{E}+01$ & $\mathrm{PCI} / \mathrm{L}$ \\
\hline $2-E 33-18$ & $8 / 04 / 87$ & BETA & & $1.4500 E+01$ & $\mathrm{PCI} / \mathrm{L}$ \\
\hline $2-E 33-18$ & $8 / 04 / 87$ & BISMUTH & $<$ & $5.0000 E+00$ & PPB \\
\hline $2-[533-18$ & $8 / 04 / 87$ & BISTHER & $<$ & $1.0000 \mathrm{E}+01$ & PPB \\
\hline $2-E 33-18$ & $8 / 04 / 87$ & BROMONE & $<$ & $1.0000 E+01$ & PPB \\
\hline $2-E 33-18$ & $8 / 04 / 87$ & BROMORM & $<$ & $1.0000 E+01$ & PPB \\
\hline $2-E 33-18$ & $8 / 04 / 87$ & CARB IDE & $<$ & $1.0000 E+01$ & PPB \\
\hline $2-E 33-18$ & $8 / 04 / 87$ & CHLBENZ & $<$ & $1.0000 \mathrm{E}+01$ & PPB \\
\hline $2-E 33-18$ & $8 / 04 / 87$ & CHLFORM & $<$ & $1.0000 \mathrm{E}+01$ & PPB \\
\hline $2-E 33-18$ & $8 / 04 / 87$ & CHLORID & & $3.5600 \mathrm{E}+03$ & PPB \\
\hline $2-E 33-18$ & $8 / 04 / 87$ & CHLTHER & $<$ & $1.0000 \mathrm{E}+01$ & PPB \\
\hline $2-[33-18$ & $8 / 04 / 87$ & CHMTHER & $<$ & $1.0000 E+01$ & PPB \\
\hline $2-[33-18$ & $8 / 04 / 87$ & $\mathrm{CO}-60$ & $<$ & $-6.0900 \mathrm{E}-01$ & $\mathrm{PCI} / \mathrm{L}$ \\
\hline $2-E 33-18$ & $8 / 04 / 87$ & CONDFLD & & $2.7700 \mathrm{E}+02$ & UMHO \\
\hline $3-18$ & $8 / 04 / 87$ & CROTONA & $<$ & $1.0000 \mathrm{E}+01$ & PPB \\
\hline $2-E 33-18$ & $8 / 04 / 87$ & CS-137 & $<$ & $-1.8900 E+00$ & $\mathrm{PCI} / \mathrm{L}$ \\
\hline $2-E 33-18$ & $8 / 04 / 87$ & CYANIDE & $<$ & $1.0000 \mathrm{E}+01$ & PPB \\
\hline $2-E 33-18$ & $8 / 04 / 87$ & DIBRCHL & $<$ & $1.0000 E+01$ & PPB \\
\hline $3-18$ & $8 / 04 / 87$ & DIBRETH & $<$ & $1.0000 E+01$ & PPB \\
\hline $3-18$ & $8 / 04 / 87$ & DIBRMET & $<$ & $1.0000 E+01$ & PPB \\
\hline $2-E 33-18$ & $8 / 04 / 87$ & DIBUTEN & $<$ & $1.0000 E+01$ & PPB \\
\hline $3-10$ & $8 / 04 / 87$ & DICDIFM & $<$ & $1.0000 \mathrm{E}+01$ & PPB \\
\hline $3-18$ & $8 / 04 / 87$ & DICETHY & $<$ & $1.0000 \mathrm{E}+01$ & PPB \\
\hline $3-18$ & $8 / 04 / 87$ & DICPANE & $<$ & $1.0000 \mathrm{E}+01$ & PPB \\
\hline $3-10$ & $8 / 04 / 87$ & DICPENE & $<$ & $1.0000 \mathrm{E}+01$ & PPB \\
\hline $2-E 33-18$ & $8 / 04 / 87$ & DIETHY & $<$ & $1.0000 E+01$ & PPB \\
\hline $2-E 33-18$ & $8 / 04 / 87$ & DIOXANE & $<$ & $5.0000 \mathrm{E}+02$ & PPB \\
\hline $3-18$ & $8 / 04 / 87$ & ETHMETH & $<$ & $1.0000 \mathrm{E}+01$ & PPB \\
\hline & $8 / 04 / 87$ & FALUMIN & $<$ & $1.5000 E+02$ & PPB \\
\hline & $8 / 04 / 87$ & FANT IMO & $<$ & $1.0000 E+02$ & PPB \\
\hline-18 & $8 / 04 / 87$ & FARSENI & & $5.0000 E+00$ & PPB \\
\hline & $8 / 04 / 87$ & FBARIUM & & $1.2000 E+01$ & PPB \\
\hline & $8 / 04 / 87$ & FBERYLL & $<$ & $5.0000 \mathrm{E}+00$ & PPB \\
\hline $3-18$ & $8 / 04 / 87$ & FCADMIU & $<$ & $2.0000 \mathrm{E}+00$ & PPB \\
\hline
\end{tabular}


TABLE 8.2. (contd)

\begin{tabular}{|c|c|c|c|c|c|}
\hline $\begin{array}{l}\text { HELL } \\
\text { NAME }\end{array}$ & $\begin{array}{c}\text { COLLECTION } \\
\text { DATE }\end{array}$ & $\begin{array}{l}\text { CONSTI IUENT } \\
\text { NAME }\end{array}$ & $\begin{array}{l}\text { LESS } \\
\text { THAN } \\
\text { FLAG }\end{array}$ & $\begin{array}{l}\text { ANALYSIS } \\
\text { VALUE }\end{array}$ & $\begin{array}{l}\text { ANALYSIS } \\
\text { UNITS }\end{array}$ \\
\hline $\begin{array}{l}2-E 33-18 \\
2-E 33-18 \\
2-E 33-18 \\
2-E 33-18 \\
2-E 33-18 \\
2-E 33-18 \\
2-E 33-18 \\
2-E 33-18 \\
2-E 33-18 \\
2-E 33-18 \\
2-E 33-18 \\
2-E 33-18 \\
2-E 33-18 \\
2-E 33-18 \\
2-E 33-18 \\
2-E 33-18 \\
2-E 33-18 \\
2-E 33-18 \\
2-E 33-18 \\
2-E 33-18 \\
2-E 33-18 \\
2-E 33-18 \\
2-E 33-18 \\
2-E 33-18 \\
2-E 33-18 \\
2-E 33-18 \\
2-E 33-18 \\
2-E 33-18 \\
2-E 33-18 \\
2-E 33-18 \\
2-E 33-18 \\
2-E 33-18 \\
2-E 33-18 \\
2-E 33-18 \\
2-E 33-18 \\
2-E 33-18 \\
2-E 33-18 \\
2-E 33-18 \\
2-E 33-18 \\
2-E 33-18 \\
2-E 33-18 \\
2-E 33-18 \\
2-E 33-18 \\
2-E 33-18 \\
2-E 33-18\end{array}$ & $\begin{array}{l}8 / 04 / 87 \\
8 / 04 / 87 \\
8 / 04 / 87 \\
8 / 04 / 87 \\
8 / 04 / 87 \\
8 / 04 / 87 \\
8 / 04 / 87 \\
8 / 04 / 87 \\
8 / 04 / 87 \\
8 / 04 / 87 \\
8 / 04 / 87 \\
8 / 04 / 87 \\
8 / 04 / 87 \\
8 / 04 / 87 \\
8 / 04 / 87 \\
8 / 04 / 87 \\
8 / 04 / 87 \\
8 / 04 / 87 \\
8 / 04 / 87 \\
8 / 04 / 87 \\
8 / 04 / 87 \\
8 / 04 / 87 \\
8 / 04 / 87 \\
8 / 04 / 87 \\
8 / 04 / 87 \\
8 / 04 / 87 \\
8 / 04 / 87 \\
8 / 04 / 87 \\
8 / 04 / 87 \\
8 / 04 / 87 \\
8 / 04 / 87 \\
8 / 04 / 87 \\
8 / 04 / 87 \\
8 / 04 / 87 \\
8 / 04 / 87 \\
8 / 04 / 87 \\
8 / 04 / 87 \\
8 / 04 / 87 \\
8 / 04 / 87 \\
8 / 04 / 87 \\
8 / 04 / 87 \\
8 / 04 / 87 \\
8 / 04 / 87 \\
8 / 04 / 87 \\
8 / 04 / 87\end{array}$ & $\begin{array}{l}\text { FCALCIU } \\
\text { FCHROMI } \\
\text { FCOPPER } \\
\text { FIRON } \\
\text { FLEAD } \\
\text { FLUORID } \\
\text { FMAGNES } \\
\text { FMANGAN } \\
\text { FMERCUR } \\
\text { FNICKEL } \\
\text { FORMALN } \\
\text { FOSMIUM } \\
\text { FPOTASS } \\
\text { FSELENI } \\
\text { FSILVER } \\
\text { FSODIUM } \\
\text { FSTRONT } \\
\text { FVANADI } \\
\text { FZINC } \\
\text { HYORSUL } \\
\text { IODOMET } \\
\text { LFLUORD } \\
\text { M-XYLE } \\
\text { METACRY } \\
\text { METHACR } \\
\text { METHBRO } \\
\text { METHCHL } \\
\text { METHONE } \\
\text { METHTHI } \\
\text { METHYCH } \\
\text { NI IRATE } \\
\text { NNOIEHY } \\
\text { OPXYLE } \\
\text { PENTACH } \\
\text { PERCENE } \\
\text { PH-LA8 } \\
\text { PHFIELD } \\
\text { PHOSPHA } \\
\text { PU-238 } \\
\text { PU39-40 } \\
\text { PYRIDIN } \\
\text { RU-106 } \\
\text { SR 90 } \\
\text { SULFATE } \\
\text { TC } \\
\end{array}$ & $\begin{array}{l}< \\
< \\
< \\
< \\
< \\
< \\
< \\
< \\
< \\
< \\
< \\
< \\
< \\
< \\
< \\
< \\
< \\
< \\
< \\
< \\
< \\
< \\
< \\
< \\
< \\
< \\
< \\
< \\
< \\
< \\
< \\
< \\
<\end{array}$ & $\begin{array}{l}8.6800 E+03 \\
1.0000 E+01 \\
1.0000 E+01 \\
5.0000 E+01 \\
5.0000 E+00 \\
5.0000 E+02 \\
7.5900 E+03 \\
5.0000 E+00 \\
1.0000 E-01 \\
1.0000 E+01 \\
5.0000 E+02 \\
3.0000 E+02 \\
4.7800 E+03 \\
5.0000 E+00 \\
1.0000 E+01 \\
2.9100 E+05 \\
3.0000 E+02 \\
2.1000 E+01 \\
6.0000 E+00 \\
1.0000 E+01 \\
1.0000 E+01 \\
3.3500 E+02 \\
1.0000 E+01 \\
1.0000 E+01 \\
1.0000 E+01 \\
1.0000 E+01 \\
1.0000 E+01 \\
1.0000 E+01 \\
1.0000 E+01 \\
1.0000 E+01 \\
1.5700 E+04 \\
1.0000 E+01 \\
1.0000 E+01 \\
1.0000 E+01 \\
1.0000 E+01 \\
7.9400 E+00 \\
7.5000 E+00 \\
1.0000 E+03 \\
6.1500 E-03 \\
9.1700 E-04 \\
5.0000 E+02 \\
6.3900 E+00 \\
2.4100 E+00 \\
3.0300 E+04 \\
2.2100 E+04\end{array}$ & $\begin{array}{l}\text { PPB } \\
\text { PPB } \\
\text { PPB } \\
\text { PPB } \\
\text { PPB } \\
\text { PPB } \\
\text { PP8 } \\
\text { PPB } \\
\text { PPB } \\
\text { PPB } \\
\text { PPB } \\
\text { PPB } \\
\text { PPB } \\
\text { PPB } \\
\text { PPB } \\
\text { PPB } \\
\text { PPB } \\
\text { PPB } \\
\text { PPB } \\
\text { PPB } \\
\text { PPB } \\
\text { PPB } \\
\text { PPB } \\
\text { PPB } \\
\text { PPB } \\
\text { PPB } \\
\text { PPB } \\
\text { PPB } \\
\text { PPB } \\
\text { PPB } \\
\text { PPB } \\
\text { PPB } \\
\text { PPB } \\
\text { PPB } \\
\text { PPB } \\
\\
\text { PPB } \\
\text { PCI/L } \\
\text { PCI I L } \\
\text { PPB } \\
\text { PCI I L } \\
\text { PCI / L } \\
\text { PPB } \\
\text { PPB }\end{array}$ \\
\hline
\end{tabular}


TABLE B.2. (contd)

\begin{tabular}{|c|c|c|c|c|c|}
\hline $\begin{array}{l}\text { WELL } \\
\text { NAME }\end{array}$ & $\begin{array}{l}\text { COLLECTION } \\
\text { DATE }\end{array}$ & $\begin{array}{l}\text { CONSTIITUENT } \\
\text { NAME }\end{array}$ & $\begin{array}{l}\text { LESS } \\
\text { THAN } \\
\text { FLAG }\end{array}$ & $\begin{array}{l}\text { ANALYSIS } \\
\text { VALUE }\end{array}$ & $\begin{array}{l}\text { ANALYSIS } \\
\text { UNITS }\end{array}$ \\
\hline $\begin{array}{l}2-E 33-18 \\
2-E 33-18 \\
2-E 33-18 \\
2-E 33-18 \\
2-E 33-18 \\
2-E 33-18 \\
2-E 33-18 \\
2-E 33-18 \\
2-E 33-18 \\
2-E 33-18 \\
2-E 33-18 \\
2-E 33-18 \\
2-E 33-18 \\
2-E 33-18 \\
2-E 33-18 \\
2-E 33-18 \\
2-E 33-18 \\
2-E 33-18 \\
2-E 33-18 \\
2-E 33-18 \\
2-E 33-18 \\
2-E 33-18 \\
2-E 33-18 \\
2-E 33-18 \\
2-E 33-18 \\
2-E 33-18 \\
2-E 33-18 \\
2-E 33-18 \\
2-E 33-18 \\
2-E 33-18 \\
2-E 33-18 \\
2-E 33-18 \\
2-E 33-18 \\
2-E 33-18 \\
2-E 33-18 \\
2-E 33-18 \\
2-E 33-18 \\
2-E 33-18 \\
2-E 33-18 \\
2-E 33-18 \\
2-E 33-18 \\
2-E 33-18 \\
2-E 33-18 \\
2-E 33-18 \\
2-E 33-18\end{array}$ & $\begin{array}{r}8 / 04 / 87 \\
8 / 04 / 87 \\
8 / 04 / 87 \\
8 / 04 / 87 \\
8 / 04 / 87 \\
8 / 04 / 87 \\
8 / 04 / 87 \\
8 / 04 / 87 \\
8 / 04 / 87 \\
8 / 04 / 87 \\
8 / 04 / 87 \\
8 / 04 / 87 \\
10 / 26 / 87 \\
10 / 26 / 87 \\
10 / 26 / 87 \\
10 / 26 / 87 \\
3 / 01 / 88 \\
3 / 01 / 88 \\
3 / 01 / 88 \\
3 / 01 / 88 \\
3 / 01 / 88 \\
3 / 01 / 88 \\
3 / 01 / 88 \\
3 / 01 / 88 \\
3 / 01 / 88 \\
9 / 02 / 88 \\
9 / 02 / 88 \\
9 / 02 / 88 \\
9 / 02 / 88 \\
9 / 02 / 88 \\
9 / 02 / 88 \\
9 / 02 / 88 \\
9 / 02 / 88 \\
9 / 02 / 88 \\
9 / 02 / 88 \\
11 / 09 / 88 \\
11 / 09 / 88 \\
11 / 09 / 88 \\
11 / 09 / 88 \\
11 / 09 / 88 \\
11 / 09 / 88 \\
11 / 09 / 88 \\
11 / 09 / 88 \\
11 / 09 / 88 \\
11 / 09 / 88\end{array}$ & $\begin{array}{l}\text { IETRANE } \\
\text { TOC } \\
\text { TOLUENE } \\
\text { TOXLDL } \\
\text { TRANDCE } \\
\text { TRCMEOL } \\
\text { TRCMFLM } \\
\text { TRCPANE } \\
\text { TRICENE } \\
\text { TRITIUM } \\
\text { U } \\
\text { VINYIDE } \\
\text { BETA } \\
\text { C0-60 } \\
\text { CS-137 } \\
\text { RU-106 } \\
\text { BETA } \\
\text { C0-60 } \\
\text { CS-137 } \\
\text { HNITRAT } \\
\text { RU-106 } \\
\text { SR 90 } \\
\text { TC-99 } \\
\text { TRITIUM } \\
\text { U } \\
\text { BETA } \\
\text { CO-60 } \\
\text { CS-137 } \\
\text { HNITRAT } \\
\text { I-129DW } \\
\text { RU-106 } \\
\text { SR 90 } \\
\text { TC-99 } \\
\text { TRITIUM } \\
\text { U } \\
\text { ALKALIN } \\
\text { AMMONIU } \\
\text { CHLORID } \\
\text { CONDFL0 } \\
\text { CYANIDE } \\
\text { FALUMIN } \\
\text { FANTIM0 } \\
\text { FBARIUM } \\
\text { FBERYLL } \\
\text { FCADMIU }\end{array}$ & $\begin{array}{l}< \\
< \\
< \\
< \\
< \\
< \\
< \\
< \\
< \\
< \\
< \\
< \\
< \\
< \\
< \\
< \\
< \\
< \\
< \\
<\end{array}$ & $\begin{array}{r}1.0000 \mathrm{E}+01 \\
5.4300 \mathrm{E}+02 \\
1.0000 \mathrm{E}+01 \\
5.4000 \mathrm{E}+00 \\
1.0000 \mathrm{E}+01 \\
1.0000 \mathrm{E}+01 \\
1.0000 \mathrm{E}+01 \\
1.0000 \mathrm{E}+01 \\
1.0000 \mathrm{E}+01 \\
1.9100 \mathrm{E}+03 \\
1.3400 \mathrm{E}+00 \\
1.0000 \mathrm{E}+01 \\
1.0600 \mathrm{E}+01 \\
2.2600 \mathrm{E}+00 \\
-4.4500 \mathrm{E}+00 \\
-4.6700 \mathrm{E}+01 \\
1.0400 \mathrm{E}+01 \\
1.4200 \mathrm{E}+00 \\
-3.7600 \mathrm{E}+00 \\
1.3700 \mathrm{E}+04 \\
-3.1800 \mathrm{E}+01 \\
-3.3700 \mathrm{E}-01 \\
3.2300 \mathrm{E}+01 \\
4.9200 \mathrm{E}+03 \\
1.6300 \mathrm{E}+00 \\
8.3500 \mathrm{E}+00 \\
-2.6500 \mathrm{E}+00 \\
-2.7100 \mathrm{E}+00 \\
1.7600 \mathrm{E}+04 \\
9.4900 \mathrm{E}-01 \\
3.3600 \mathrm{E}+01 \\
-3.4400 \mathrm{E}-02 \\
2.1200 \mathrm{E}+01 \\
5.4700 \mathrm{E}+03 \\
1.6600 \mathrm{E}+00 \\
1.1100 \mathrm{E}+05 \\
5.0000 \mathrm{E}+01 \\
5.0000 \mathrm{E}+03 \\
2.8800 \mathrm{E}+02 \\
1.0000 \mathrm{E}+01 \\
1.5000 \mathrm{E}+02 \\
1.0000 \mathrm{E}+02 \\
2.4000 \mathrm{E}+01 \\
5.0000 \mathrm{E}+00 \\
2.0000 \mathrm{E}+00\end{array}$ & $\begin{array}{l}\mathrm{PPB} \\
\mathrm{PPB} \\
\mathrm{PPB} \\
\mathrm{PPB} \\
\mathrm{PPB} \\
\mathrm{PPB} \\
\mathrm{PPB} \\
\mathrm{PPB} \\
\mathrm{PPB} \\
\mathrm{PCI} / \mathrm{L} \\
\mathrm{PCI} / \mathrm{L} \\
\mathrm{PPB} \\
\mathrm{PCI} / \mathrm{L} \\
\mathrm{PCI} / \mathrm{L} \\
\mathrm{PCI} / \mathrm{L} \\
\mathrm{PCI} / \mathrm{L} \\
\mathrm{PCI} / \mathrm{L} \\
\mathrm{PCI} / \mathrm{L} \\
\mathrm{PCI} / \mathrm{L} \\
\mathrm{PPB} \\
\mathrm{PCI} / L \\
\mathrm{PCI} / \mathrm{L} \\
\mathrm{PCI} / \mathrm{L} \\
\mathrm{PCI} / \mathrm{L} \\
\mathrm{PCI} / \mathrm{L} \\
\mathrm{PCI} / \mathrm{L} \\
\mathrm{PCI} / \mathrm{L} \\
\mathrm{PCI} / \mathrm{L} \\
\mathrm{PPB} \\
\mathrm{PCI} / \mathrm{L} \\
\mathrm{PCI} / \mathrm{L} \\
\mathrm{PCI} / \mathrm{L} \\
\mathrm{PCI} / \mathrm{L} \\
\mathrm{PCI} / \mathrm{L} \\
\mathrm{PCI} / \mathrm{L} \\
\mathrm{PPB} \\
\mathrm{PPB} \\
\mathrm{UMH} 0 \\
\mathrm{PPB} \\
\mathrm{PPB} \\
\mathrm{PPB} \\
\mathrm{PPB} \\
\mathrm{PPB} \\
\mathrm{PPB}\end{array}$ \\
\hline
\end{tabular}


IABLE B.2. (contd)

WELL
NAME
$2-E 33-18$
$2-E 33-18$
$2-E 33-18$
$2-E 33-18$
$2-E 33-18$
$2-E 33-18$
$2-E 33-18$
$2-E 33-18$
$2-E 33-18$
$2-E 33-18$
$2-E 33-18$
$2-E 33-18$
$2-E 33-18$
$2-E 33-18$
$2-E 33-18$
$2-E 33-18$
$2-E 33-18$
$2-E 33-18$
$2-E 33-18$
$2-E 33-18$
COLLECTION DATE

$11 / 09 / 88$

$11 / 09 / 88$

$11 / 09 / 88$

$11 / 09 / 88$

$11 / 09 / 88$

$11 / 09 / 88$

$11 / 09 / 88$

$11 / 09 / 88$

$11 / 09 / 88$

$11 / 09 / 88$

$11 / 09 / 88$

$11 / 09 / 88$

$11 / 09 / 88$

$11 / 09 / 88$

$11 / 09 / 88$

$11 / 09 / 88$

$11 / 09 / 88$

$11 / 09 / 88$

$11 / 09 / 88$

$11 / 09 / 88$

$\begin{array}{cc} & \text { LESS } \\ \text { CONSTITUENT } & \text { THAN } \\ \text { NAME } & \text { FLAG }\end{array}$

FCALCIU

FCHROMI

FCOPPER

FIRON

FLUORID

FMAGNES

FMANGAN

FNICKEL

FPOTASS

FSILVER

FSODIUM

FSTRONT

FVANAD I

FZINC

NITRATE

PH-LAB

PHFIELD

PHOSPHA

SULFATE

TOC

$\begin{array}{lll} & 3.3500 \mathrm{E}+04 & \text { PPB } \\ < & 1.0000 \mathrm{E}+01 & \mathrm{PPB} \\ < & 1.0000 \mathrm{E}+01 & \mathrm{PPB} \\ < & 3.0000 \mathrm{E}+01 & \mathrm{PPB} \\ & 5.0000 \mathrm{E}+02 & \mathrm{PPB} \\ < & 1.0900 \mathrm{E}+04 & \mathrm{PPB} \\ < & 5.0000 \mathrm{E}+00 & \mathrm{PPB} \\ & 1.0000 \mathrm{E}+01 & \mathrm{PPB} \\ < & 5.6200 \mathrm{E}+03 & \mathrm{PPB} \\ & 1.0000 \mathrm{E}+01 & \mathrm{PPB} \\ & 1.3400 \mathrm{E}+04 & \mathrm{PPB} \\ & 1.7800 \mathrm{E}+02 & \mathrm{PPB} \\ < & 2.0000 \mathrm{E}+01 & \mathrm{PPB} \\ & 5.0000 \mathrm{E}+00 & \mathrm{PPB} \\ & 1.9900 \mathrm{E}+04 & \mathrm{PPB} \\ & 7.9000 \mathrm{E}+00 & \\ & 8.0000 \mathrm{E}+00 & \\ < & 1.0000 \mathrm{E}+03 & \mathrm{PPB} \\ & 2.4600 \mathrm{E}+04 & \mathrm{PPB} \\ < & 5.0000 \mathrm{E}+02 & \mathrm{PPR}\end{array}$

ANALYSIS

VALUE

ANALYSIS

UNITS

PB

PB

$P P B$

PPB

$P P B$

$P P B$

PPB

PPB

$P P B$

PPB

PB

PPB

$\mathrm{PPR}$ 
APPENDIX C

SAMPLING AND ANALYSIS PLAN 
APPENDIX C

SAMPLING AND ANALYSIS PLAN

This plan introduces the procedures and methods that will be used for sample collection (including well evacuation and sample withdrawal methods), field measurements, sample preservation and shipment, chemical analysis, chain of custody, and quality control.

All sampling activities are currently performed by Pacific Northwest Laboratory (PNL). United States Testing Company, Incorporated (UST), currently conducts sample analyses for most constituents.

\section{C.1 SAMPLE COLLECTION PROCEDURES}

The procedures for ground-water sample collection, water-leve] measurements, and field measurements are contained in Procedures for GroundWater Investigations (PNL 1989). Specific applicable procedures are:

- GC-1 - Ground-Water Sample Collection Procedure

- GC-2 - In-Line Sample Filtration Procedure

- GC-3 - Disposal of Purge Water from Monitoring Wells

- FA-1 - Temperature Measurement Procedure

- FA-2 - Calibration of Conductivity Meter and Measurement of Field Conductivity

- FA-3 - Calibration of pH Meter and Measurement of Field pH

- WL-1 - Water-Leve1 Measurement Procedure

- WL-2 - Procedure for Standardizing Steel Tapes.

\section{C.2 CHAIN-OF-CUSTODY PROCEDURES}

Chain-of-custody procedures are contained in Procedures for GroundWater Investigations (PNL 1989). The specific applicable procedure is number 
AD-2, Ground-Water Sample Chain-of-Custody Procedure. The history of the custody of each sample will be documented according to this procedure.

\section{C.3 ANALYTICAL METHODS}

TABLE C 1. Preservation Techniques, Analytical Methods Used, and the Current Detection Levels for Listed Constituents as of January 1,1989

\begin{tabular}{|c|c|c|c|}
\hline Consti & $\begin{array}{l}\text { Collection and } \\
\text { Preservation }(a, b)\end{array}$ & $\begin{array}{r}\text { Analysjs } \\
\text { Methods (c) }\end{array}$ & $\begin{array}{l}\text { Detection } \\
\text { Limit. ppb(d) }\end{array}$ \\
\hline ICP METALS & Filt & & \\
\hline $\begin{array}{l}\text { Beryllium } \\
\text { Strontium } \\
\text { Zinc } \\
\text { Calcium } \\
\text { Barium } \\
\text { Cadmium } \\
\text { Chromium } \\
\text { Lead } \\
\text { Silver } \\
\text { Sodium } \\
\text { Nickel } \\
\text { Copper } \\
\text { Vanadium } \\
\text { Antimony } \\
\text { Aluminum } \\
\text { Manganese } \\
\text { Potassium } \\
\text { Iron } \\
\text { Magnesium } \\
\text { Boron } \\
\text { Cobalt } \\
\text { Lithium } \\
\text { Molybdenum } \\
\text { Silicon } \\
\text { Tin } \\
\text { Titanium } \\
\text { Zirconium } \\
\text { Arsenic } \\
\text { Mercury } \\
\text { Selenium } \\
\text { Lead }\end{array}$ & $\begin{array}{l}\mathrm{P}, \mathrm{HNO}_{3} \text { to } \mathrm{pH}<2 \\
\mathrm{G}, \mathrm{HNO}_{3} \text { to } \mathrm{pH}<2 \\
\mathrm{P}, \mathrm{HNO}_{3} \text { to } \mathrm{pH}<2 \\
\mathrm{P}, \mathrm{HNO}_{3} \text { to } \mathrm{pH}<2\end{array}$ & $\begin{array}{ll}\text { SW-846, } & \# 7060 \\
\text { SW-846, } & \# 7470 \\
\text { SW-846, } \# 7740 \\
\text { SW-846, } \# 7421\end{array}$ & $\begin{array}{r}3 \\
10 \\
5 \\
50 \\
6 \\
5 \\
10 \\
30 \\
10 \\
200 \\
10 \\
10 \\
5 \\
100 \\
150 \\
5 \\
100 \\
30 \\
50 \\
10 \\
20 \\
10 \\
40 \\
50 \\
30 \\
60 \\
50 \\
5 \\
0.1 \\
5 \\
5\end{array}$ \\
\hline
\end{tabular}


IABLE C.1. (contd)

Collection and Constituent

AMIOWS BY IC (f)
Detection Limit, ppb (d)

$\left.\begin{array}{l}\text { Nitrate } \\ \text { Sulfate } \\ \text { Fluoride } \\ \text { Chloride } \\ \text { Phosphate } \\ \text { Bromide } \\ \text { Nitrite }\end{array}\right\}$

$P$, None

EPA Method

\section{PESTICIDES}

\begin{tabular}{|c|c|c|}
\hline $\begin{array}{l}\text { Endrin } \\
\text { Methoxychlor } \\
\text { Toxaphene } \\
\text { Lindane (four isomers) }\end{array}$ & $G$, None & SW-846, \#8080 \\
\hline
\end{tabular}

\section{HERBICIDES}

$\left.\begin{array}{l}2,4-D \\ 2,4-5-T P \text { silvex } \\ 2,4,5-T\end{array}\right\}$ G, None $\quad$ SW-846, \#8150

\section{VOLATILE ORGANICS (VOA)}

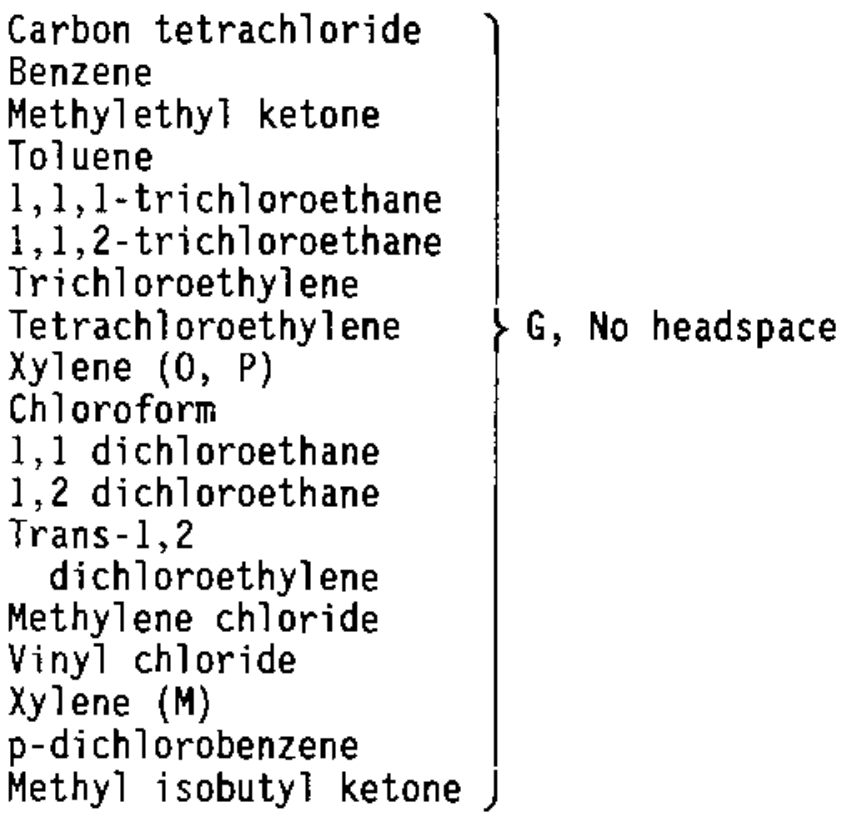




\section{TABLE C.1. (contd)}

\begin{tabular}{|c|c|c|c|}
\hline Constituent & $\begin{array}{l}\text { Collection and } \\
\text { Preservation }(a, b)\end{array}$ & $\begin{array}{r}\text { Analys } j \text { s } \\
\text { Methods }(c)\end{array}$ & $\begin{array}{r}\text { Detection } \\
\text { Limit, ppb } \\
\end{array}$ \\
\hline \multicolumn{4}{|l|}{ RADIOLOGICAL } \\
\hline $\begin{array}{l}\text { Radium } \\
\text { Gross alpha } \\
\text { Gross beta } \\
\text { Tritium }\end{array}$ & $\begin{array}{l}\mathrm{P}, \mathrm{HNO}_{3} \text { to } \mathrm{pH}<2 \\
\mathrm{P}, \mathrm{HNO}_{3} \text { to } \mathrm{pH}<2 \\
\mathrm{P}, \mathrm{HNO}_{3} \text { to } \mathrm{pH}<2 \\
\mathrm{P}, \text { None }\end{array}$ & $\begin{array}{l}\text { SW-846, (h) \#9315 } \\
\text { SW-846, \#9310 } \\
\text { SW-846, \#9310 } \\
\text { ASTM, D2476-81 }\end{array}$ & $\begin{array}{l}1 \mathrm{pCi} / \mathrm{L} \\
4 \mathrm{pCi} / \mathrm{L} \\
8 \mathrm{pCi} / \mathrm{L} \\
500 \mathrm{pCi}\end{array}$ \\
\hline \multicolumn{4}{|l|}{ OTHER } \\
\hline $\begin{array}{l}\text { Coliform bacteria } \\
\text { Temperature }\end{array}$ & $\begin{array}{l}\text { P, None } \\
\text { Field measurement }\end{array}$ & $\begin{array}{l}\text { SW-846, \#9131 } \\
\text { PNL-MA-567, (1) } \\
\text { FA-1 }\end{array}$ & $2.2 \mathrm{MPN}$ \\
\hline $\begin{array}{l}\text { Specific conductance } \\
\text { pH } \\
\text { Total organic halogen, } \\
\text { low detection level }\end{array}$ & $\begin{array}{l}\text { Field measurement } \\
\text { Field measurement } \\
\mathrm{G}, \mathrm{H}_{2} \mathrm{SO}_{4} \text { to } \mathrm{pH}<2 \\
\text { No headspace }\end{array}$ & $\begin{array}{l}\text { PNL-MA-567, FA-2 } \\
\text { PNL-MA-567, FA-3 } \\
\text { SW-846, } \$ 9020\end{array}$ & 10 \\
\hline $\begin{array}{l}\text { Total organic carbon } \\
\text { Total carbon } \\
\text { Ammonium ion } \\
\text { Phenol } \\
\text { Cyanide } \\
\text { Hydrazine } \\
\text { Total dissolved solids }\end{array}$ & $\begin{array}{l}\mathrm{G}, \mathrm{H}_{3} \mathrm{PO}_{4} \text { to } \mathrm{pH}<2 \\
\mathrm{G}, \mathrm{None} \\
\mathrm{G}, \mathrm{H}_{2} \mathrm{SO}_{4} \text { to } \mathrm{pH}<2 \\
\mathrm{G} \text {, None } \\
\mathrm{P} \text {, NaOH to } \mathrm{pH}<2 \\
\mathrm{G}, \mathrm{HCl} \\
\mathrm{P}, \mathrm{None}\end{array}$ & $\begin{array}{l}\text { SW-846, \#9060 } \\
\text { SW-846, \#9060 } \\
\text { ASTM D1426-D }(j) \\
\text { SW-846, \#8040 } \\
\text { SW-846, \#9010 } \\
\text { ASTM Di3B5 } \\
\text { Std. Methods 209B (k) }\end{array}$ & $\begin{array}{r}2000 \\
2000 \\
50 \\
10 \\
10 \\
-\quad 30\end{array}$ \\
\hline
\end{tabular}

(a) P, plastic; G, glass.

(b) A11 samples will be cooled to $4^{\circ} \mathrm{C}$ upon collection.

(c) Constituents grouped together are analyzed by the same method.

(d) Detection limit units except where indicated.

(e) Adapted from USEPA Method 6010; (EPA 1986).

(f) IC, ion chromatography.

(g) In-house analytical method from UST Procedure Manual UST-RD-PM; adapted from Method 300.0, EPA 600/4-84-017 (March 1984).

(h) The method also references ASTM D2460, "Standard Test Method for Radionuclides of Radium in Water"; and "Prescribed Procedures for Measurement of Radioactivity in Drinking Water, "EPA-6004-80-032, edited by Herman L. Krieger and Earl L. Whittaker, 1980, Environmenta] Monitoring and Support Laboratory, Cincinnati, Ohio.

(i) (PNL 1989)

(j) By ion selective electrode.

(k) Standard Methods for the Examination of Water and Wastewater, 16th ed., 1985, published jointly by the American Public Health Association, American Water Works Association and Water Pollution Control Federation (ALPHA 1985). 
IABLE C.2. Preservation Techniques, Analytical Methods Used, and the Current Detection Levels for Additional Constituents on the 9905 and Appendix IX Lists (a)

Collection and

Constituent
Analys js

Methods (d)
Detection Limit, ppb (e)

\section{ICP METALS, ENHANCED ADOITIONS}

Thallium

$\mathrm{P}, \mathrm{HNO}_{3}$ to $\mathrm{pH}<2 \quad \mathrm{SW}-846, \# 7840$

\section{IHIOUREA GROUP, ENHANCED ADDITIONS}

$\left.\begin{array}{l}\text { Thiourea } \\ \text { 1-Acety]-2-thiourea } \\ \text { 1-(0-Chlorophenyl) } \\ \text { thiourea } \\ \text { Diethylsti]besterol } \\ \text { Ethylenethiourea } \\ \text { l-Naphthy]-2-thiourea } \\ \text { N-Phenylthiourea }\end{array}\right\} G$, None

\section{PESTICIDES, ENHANCED ADDITIONS}

$\mathrm{SW}-846, \# 8330$

200

200

200

500
0.1

1

0.1

0.1

0.1

SW-846, \#8080

0.1

0.1

0.5

0.1

0.1

1

0.1 300

\section{PHOSPHOROUS PESTICIDES}

Carbophenothion

Tetraethyl pyrophosphate

Disulfoton

Dimethoate

Methyl parathion

Parathion

Phorate

$G$, None

SW-846, \#8140 
IABLE C.2. (contd)

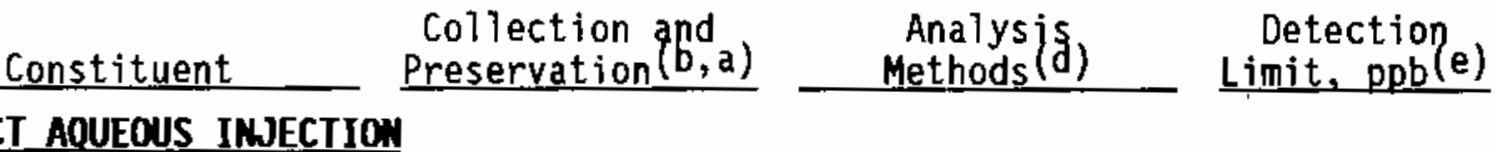

\section{DIRECT AQUEOUS INJECTION}

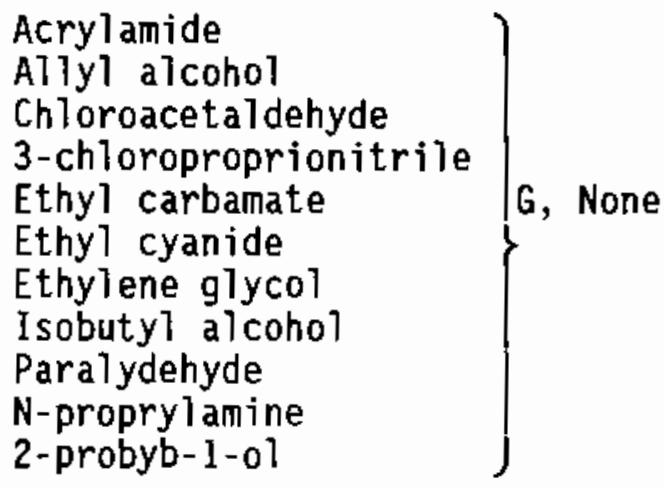

10,000
2,500
16,000
4,000
5,000
2,000
10,000
1,000
2,000
10,000
8,000

\section{DIOXINS}

\begin{tabular}{|c|c|c|}
\hline $\begin{array}{l}\text { PCDDs } \\
\text { PCDF S } \\
2,3,7,8 \text { TCOD }\end{array}$ & $G$, None & $\mathrm{SW}-846_{7} \# 8280$ \\
\hline
\end{tabular}

\section{YOAS, ENHANCED ADDITIONS}

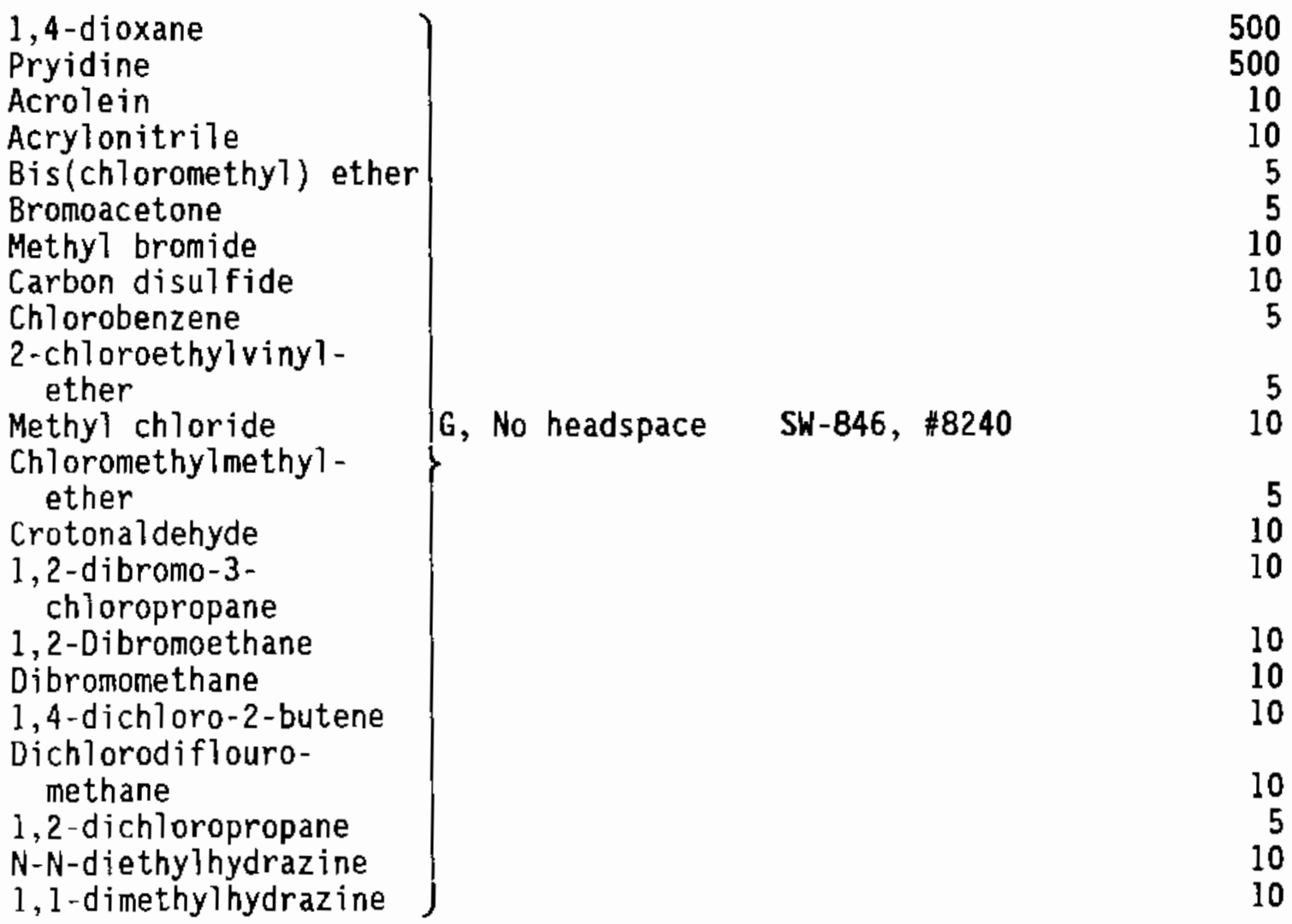


IABLE C.2. (contd)

\begin{tabular}{|c|c|c|c|}
\hline Constituent & $\begin{array}{c}\text { Collection and } \\
\text { Preservation }(b, c) \\
\end{array}$ & $\begin{array}{l}\text { Analysjos } \\
\text { Methods (d) }\end{array}$ & $\begin{array}{r}\text { Detection } \\
\text { Limit, } \mathrm{ppb}(\mathrm{e}) \\
\end{array}$ \\
\hline $\begin{array}{l}\text { 1,2-dimethylhydrazine } \\
\text { Iodomethane } \\
\text { Methacrylonitrile } \\
\text { Methanethiol } \\
\text { Pentachloroethane } \\
\text { I,1,2,2- } \\
\text { tetrachloroethane } \\
\text { Bromoform } \\
\text { Trichloromethanethiol } \\
\text { Trichloromonofluoro- } \\
\text { methane } \\
\text { 1,2,3-trichloropropane } \\
\text { Acetonitrile } \\
\text { Formaldehyde } \\
\text { Ethylene oxide } \\
\text { Ethyl methacrylate } \\
\text { Ethyl benzene } \\
\text { Styrene } \\
\text { Bromodichloromethane } \\
\text { Dibromochloromethane } \\
\text { 2-hexanone } \\
\text { l,3-dichloropropene } \\
\text { Ailyl chloride } \\
\text { Chlorethane } \\
\text { Propionitrile } \\
\text { Vinyl acetate } \\
\text { Additional voAs (g) }\end{array}$ & 6, No headspace & $S W-846, \# 8240$ & $\begin{array}{r}10 \\
10 \\
10 \\
10 \\
10 \\
5 \\
5 \\
5 \\
10 \\
10 \\
10 \\
500 \\
10 \\
10 \\
5 \\
5 \\
5 \\
5 \\
50 \\
5 \\
100 \\
10 \\
5 \\
5\end{array}$ \\
\hline
\end{tabular}

\section{SEMIVOLATILE ORGANIC ARALYSIS (ABM)}

Chiorobenzene

Creso]

1,2-dichlorobenzene

1,3-dichlorobenzene

P-dichlorobenzene

Hexachiorobenzene

Pentachlorobenzene

Pentachiorophenol

Pentach?orophenol

1,2,4,5-tetrach] orobenzene

1,2,4-trichlorobenzene

Hexach lorophene

Naphthalene

1,2,3-trichlorobenzene

Phenol

$1,3,5$-trichiorobenzene 
TABLE C.2. (contd)

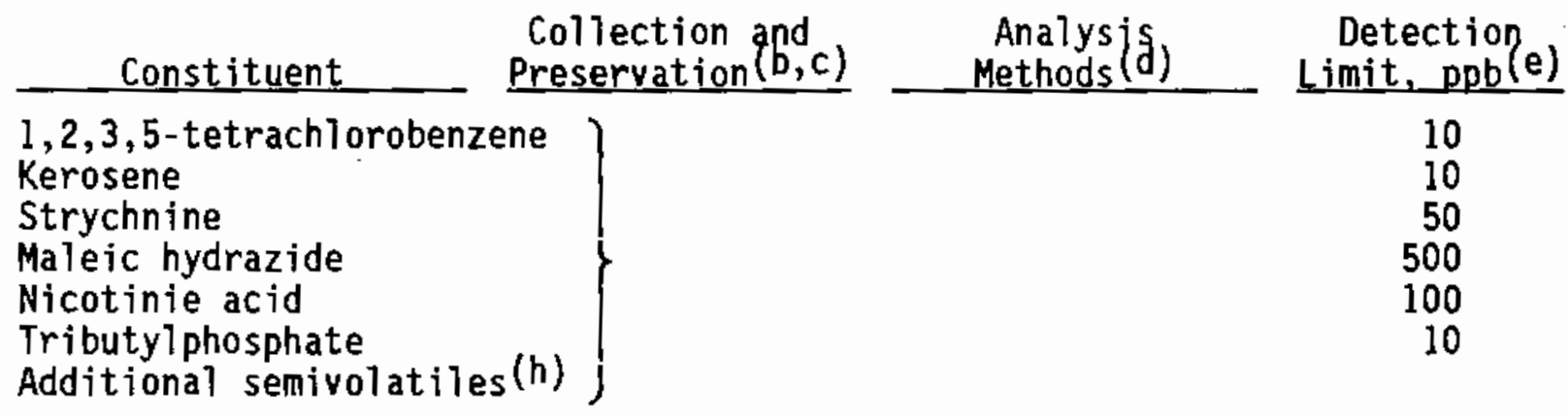

\section{OTHER}

Polychlorinated

G, None

SW-846, \#8080

biphenyls

Perchiorate

Sulfide

$P$, None

$70-I C(i, j)$

500

$P$, NaOH/Zinc

SW-846, \#9030

1,000

Citrus red \#2 acetate

AOAC $\# 34.015 B$

1,000

(a) WAC 173-303-9905, Dangerous waste Constituents 1ist; and EPA Appendix IX, Ground-Water Monitoring List, 40 CFR 264.

(b) P, plastic; G, glass.

(c) A7l samples will be cooled to $4^{\circ} \mathrm{C}$ upon collection.

(d) Constituents grouped together are analyzed by the same method.

(e) Detection limit units except where indicated.

(f) DAI, direct aqueous injection.

(g) Tentatively identified compounds are listed when seen, but there are no established detection limits for these.

(h) There are more than 100 additional semivolatile compounds on the "long list" that are not listed here. Most of these analyses have a detection level of $10 \mathrm{ppb}$.

(i) In-house analytical method from UST Procedure Manual, UST-RD-PM, adapted from Method 300.0, EPA-600/4-84-017 (March 1984).

(j) IC, ion chromatography.

\section{C.4 QUALITY ASSURANCE/QUALITY CONTROL}

\section{Quality Assurance}

Quality assurance (QA) will be conducted in accordance with the PNL quality assurance manual. A generic QA plan describing the manner in which generic $Q A$ requirements are to be met has been prepared in accordance with that manual. Any site-specific requirements are presented in the Project Management Plan. 


\section{Quality Control}

The purpose of quality control is to determine and document the quality of the analytical results being produced by the laboratory and to bring potential problems with analyses to the attention of UST for corrective actions as needed. The QC effort has two main components: 1) routine internal checks performed by UST, and 2) external checks conducted by PNL to independent1y evaluate UST performance. The scope of these efforts is described in the following sections.

United States Testing Company, Incorporated, Internal Quality Control

Internal quality control at UST includes general practices applicable to a wide range of analyses, as well as specific procedures stipulated for particular analyses. The quality control and quality assurance programs at UST are documented in the UST Quality Control Manual (Hembree et al: 1986) and the Quality Assurance Manual (Hembree and Lardy 1986). UST produces a quarterly Quality Control Report of Hazardous Substance_Anaiyses and submits it to PNL for review by subcontracts, sample analyses management, quality control, and statistical task leaders of the ground-water monitoring program.

\section{UST External Quality Control}

Pacific Northwest Laboratory witl use both interlaboratory comparisons and spiked, replicate, and biank samples in evaluating the accuracy of results from UST. The purpose and scope of each of these is as follows.

Interlaboratory comparisons using field samples are conducted to determine if the results obtained by the primary laboratory, UST, are comparable to those obtained from other laboratories. Comparisons are currently being conducted for anions, volatile organic constituents, metals, and gross alpha and beta. Each month, replicate samples from selected wells are delivered to four different PNL laboratories. The results from these PNL 1aboratories are then compared with the results from UST. Samples sent to PNL laboratories are from the same sampling set as those to be analyzed in duplicate by UST.

Replicate analyses of field samples are conducted to establish how much variability might be expected in the laboratory measurements performed on 
nearly identical samples. Trip (transport) blanks and transfer blanks are submitted to UST to determine whether environmentai conditions encountered during collection and transportation of samples have affected the results obtained by analysis. One set of trip blanks and transfer blanks are submitted each sample period per sample area at the rate of at least one for 1 to 20 wells. These blanks are analyzed for volatile organic constituents. Blanks for a wide range of analytes are submitted to UST monthly to check for container or laboratory contamination.

Blind samples are submitted to UST to estimate the bias of analytical laboratory procedures and to determine when this bias exceeds control limits. Blind standard samples prepared by PNL containing metals, anions, herbicides, pesticides, and volatile organic compounds have been submitted quarterly since January 1986. These samples were prepared by PNL with materials supplied by Environmental Resource Associates. Additional blind samples prepared with materials supplied by the U.S. Environmental Protection Agency (EPA) were added in June 1986. The constituents included are ammonium ion, cyanide, semivolatile compounds, and an expanded number of pesticides and volatile organic compounds. Other constituents, not available in EPA performance samples, have been added. These include thiourea, phosphorous pesticides, ethylene glycol, sulfide, perchiorate, and dioxin.

United States Testing Company, Incorporated, has also participated in the EPA-sponsored Water Pollution Laboratory Performance Evaluation Studies and the Water Supply Laboratory Performance Evaluation Studies since 1986.

\section{C.5 REFERENCES}

McGhan, V. L., P. J. Mitchell and R. S. Argo. 1985. Hanford Wells.

PNL-5397, Pacific Northwest Laboratory, Richland, Washington.

PNL. 1989. Procedures for Ground-Water Investigations. PNL-6894, Pacific Northwest Laboratory, Richland, Washington.

UST. 1986. Procedures Manual. UST-RD-PM-9-80, Rev. 3, United States Testing Company, Inc., Richi and, Washington. 


\section{DISTRIBUTION}

No. of

Copies

OFFSITE

2 DOE/Office of Scientific and Technical Information

\section{ONSITE}

4 DOE Richland Operations office

E. A. Bracken

A. J. Knepp

K. M. Thompson

M. L. Tiernan

22 Westinghouse Hanford Company

D. L. Armstrong

J. R. Brodeur

D. R. Duncan

G. C. Evans

K. R. Fecht

C. E. Hodge

R. L. Jackson

C. J. Koizumi

A. G. Law

R. B. Hercer

N. M. Naiknimbalkar

J. D. Payne

S. M. Price

W. H. Price

S. P. Reidel

D. R. Schell

J. S. Schmid

J. A. Serkowski

L. C. Swanson

D. A. Turner

L. D. Vance

D. C. Weekes
No. of

Copies

29 Pacific Northwest Laboratory

S. P. Airhart

B. N. Bjornstad (3)

R. W. Bryce

M. A. Chamness

J. W. FaTco

M. D. Freshiey

T. J. Gilmore

L. K. Grove

J. M. Hales

P. C. Hays

E. J. Jensen

G. V. Last

R. E. Lundgren

S. P. Luttre]1

P. J. Mitchell

R. Schalla

R. L. Skaggs

R. M. Smith

J. A. Stott Temyre

S. S. Teel

R. E. Wildung

Publishing Coordination

Technical Report Files (5) 
